Andrews University

Digital Commons @ Andrews University

\title{
The Doctrine of Prevenient Grace in the Theology of Jacobus Arminius
}

Abner F. Hernandez

Andrews University, abnerh@andrews.edu

Follow this and additional works at: https://digitalcommons.andrews.edu/dissertations

Part of the Religious Thought, Theology and Philosophy of Religion Commons

\section{Recommended Citation}

Hernandez, Abner F., "The Doctrine of Prevenient Grace in the Theology of Jacobus Arminius" (2017).

Dissertations. 1670.

https://digitalcommons.andrews.edu/dissertations/1670

https://dx.doi.org/10.32597/dissertations/1670

This Dissertation is brought to you for free and open access by the Graduate Research at Digital Commons @ Andrews University. It has been accepted for inclusion in Dissertations by an authorized administrator of Digital Commons@ Andrews University. For more information, please contact repository@andrews.edu. 



\begin{abstract}
THE DOCTRINE OF PREVENIENT GRACE IN THE THEOLOGY OF JACOBUS ARMINIUS
\end{abstract}

by

Abner F. Hernandez Fernandez

Adviser: Jerry Moon 


\title{
ABSTRACT OF GRADUATE RESEARCH
}

Dissertation

\author{
Andrews University
}

Seventh-day Adventist Theological Seminary

\section{Title: THE DOCTRINE OF PREVENIENT GRACE IN THE THEOLOGY OF JACOBUS ARMINIUS}

Name of researcher: Abner F. Hernandez Fernandez

Name and degree of faculty adviser: Jerry Moon, Ph.D.

Date completed: April 2017

\section{Topic}

This dissertation addresses the problem of the lack of agreement among interpreters of Arminius concerning the nature, sources, development, and roles of prevenient grace in Arminius's soteriology.

\section{Purpose}

The dissertation aims to investigate, analyze, and define the probable sources, nature, development, and role of the concept of prevenient or "preceding" grace in the theology of Jacobus Arminius (1559-1609). 
Sources

The dissertation relies on Arminius's own writings, mainly the standard London Edition, translated by James Nichols and Williams Nichols. However, I also frequently consulted the original Latin edition of his works when needed to clarify some translations. Secondary sources played an important role in the narrative of Arminius's world, life, and ministry as well as for the background of prevenient grace. I also consulted secondary sources to check, balance, and support my own reading of Arminius on prevenient grace.

\section{Conclusions}

Arminius placed prevenient grace rather than human free will at the center of his soteriology and developed this doctrine primarily in continuity with Reformed and Protestant theological precedents and frameworks rather than uniquely Catholic sources and views. For Arminius, prevenient grace is the working of the Holy Spirit that precedes any kind of human participation or acceptance in salvation. Prevenient grace works unavoidably, restoring and healing human freedom of will; only then does it work in a resistible way in the working of salvation. Although there is a special connection between the internal working of the Holy Spirit and the external preaching of the Word, prevenient grace as the working of the Holy Spirit is not limited to this event. The Holy Spirit works apart from the preached word, in ways inscrutable to the human mind. The role of prevenient grace in regeneration and faith, and the relation between prevenient grace and divine foreknowledge also support the conclusion that prevenient grace is the organizing principle of Arminius's soteriology. 
Andrews University

Seventh-day Adventist Theological Seminary

\title{
THE DOCTRINE OF PREVENIENT GRACE IN THE THEOLOGY OF JACOBUS ARMINIUS
}

\author{
A Dissertation \\ Presented in Partial Fulfillment \\ of the Requirements for the Degree \\ Doctor of Philosophy
}

by

Abner F. Hernandez Fernandez

June 2017 
(C) Copyright by Abner F. Hernandez Fernandez 2017 All Rights Reserved 


\title{
THE DOCTRINE OF PREVENIENT GRACE IN
}

\section{THE THEOLOGY OF JACOBUS ARMINIUS}

\author{
A dissertation \\ presented in partial fulfillment \\ of the requirements for the degree \\ Doctor of Philosophy
}

by

Abner F. Hernandez Fernandez

\section{APPROVAL BY THE COMMITTEE:}

Faculty Adviser, Jerry Moon

Professor of Church History

Martin Hanna

Associate Professor of Historical

Theology

John Reeve

Assistant Professor of Church History

Chair, Department of Church History

Nicholas Miller

Professor of Church History

Keith Stanglin

Professor of Historical Theology

Austin Graduate School of Theology
Director of $\mathrm{PhD} / \mathrm{ThD}$ Program

Tom Shepherd

Dean, SDA Theological Seminary Jiří Moskala 
To Keila, Jasiel, and Josias

In hope that

I always remember that

you are the treasures of my life 


\section{TABLE OF CONTENT}

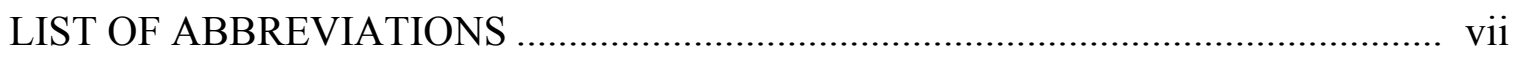

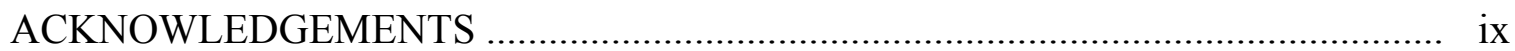

Chapter

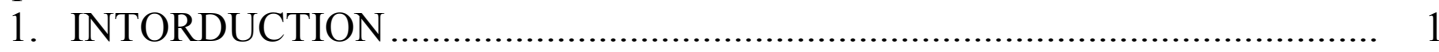

Background to the Study …………......................................................... 1

Statement of Scholarship ........................................................................ 6

Problem Statement........................................................................... 17

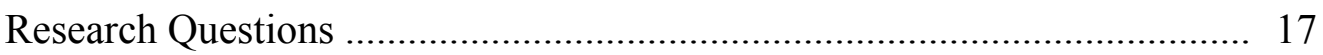

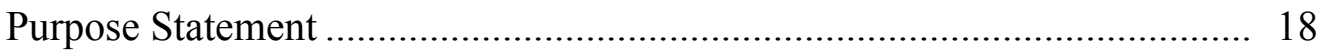

Thesis Statement............................................................................ 18

Scope and Deliminations ………………………………………..... 18

Justification............................................................................... 19

Methodology and Outline ....................................................................... 22

2. THE LIFE AND WORK OF JACOBUS ARMINIUS …................................. 27

Historical Introduction........................................................................... 27

The Social, Religious, and Intellectual World of Arminius .......................... 29

The Social World of Arminius ............................................................. 29

The Religious World of Arminius ........................................................ 35

The Theological World of Arminius ....................................................... 41

Central Theological Concepts .......................................................... 44

The Wider Context of Arminius's Theological World...................... 47

Jacobus Arminius: The Person ................................................................. 51

Early Years: Family and Patrons ....................................................... 51

Student Life: Theological Influences ................................................ 57

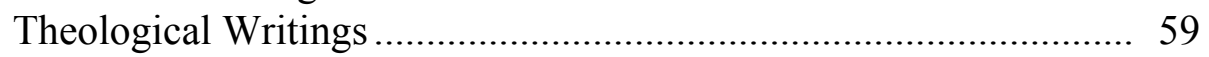

Professional Life: Pastor and Professor................................................ 61

The Final Days: Controversies and Death.............................................. 70

Images and Self-Image of Arminius........................................................ 72

Arminius's Theological Method.................................................................. 83

Summary and Conclusion....................................................................... 87

3. HISTORICAL BACKGROUND OF THE DOCTRINE OF PREVENIENT

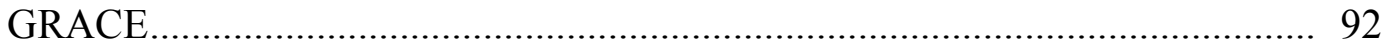

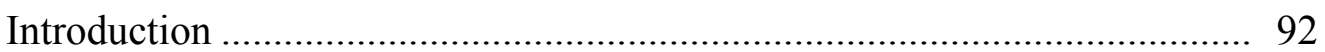

The Beginning of the Christian Concept of Prevenient Grace ...................... 93

Saint Augustine of Hippo ………………………………………...... 93

Prevenient Grace in the Theology of the Medieval Church ............................ 105 
Prevenient Grace after the Pelagian Controversy: The Second

Council of Orange ......................................................................... 106

The Medieval Theologians and the Council of Trent............................. 114

Prevenient Grace in the Theology of the Protestant Reformation................. 131

Martin Luther.............................................................................. 132

John Calvin ................................................................................. 135

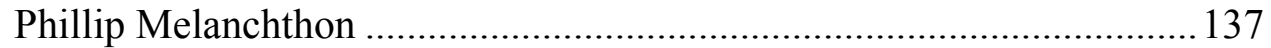

The Role of Human Will ............................................................... 140

The Previent Grace of God........................................................... 141

Radical Reformers ......................................................................... 146

Summary and Conclusion................................................................. 150

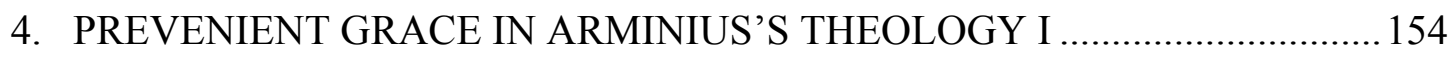

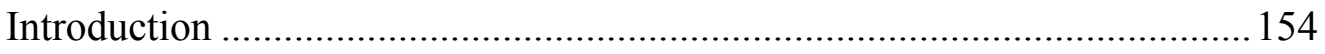

Prevenient Grace: The Need for Regeneration......................................... 154

The Human Beings in Need of Prevenient Grace: Original Sin and

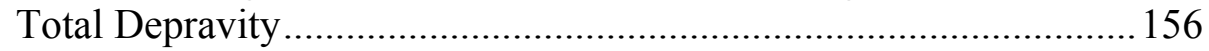

The Nature of Prevenient Grace ............................................................ 160

Three Main Concepts of Grace........................................................... 160

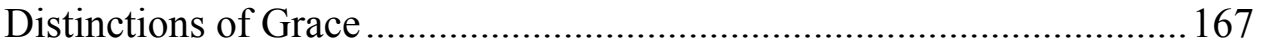

Prevenient Grace: Its Content and Definition ............................................ 168

Arminius's Biblical Support for the Concept of Prevenient Grace............... 172

The Operation of Prevenient Grace ..................................................... 174

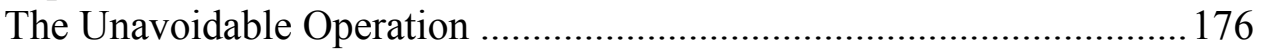

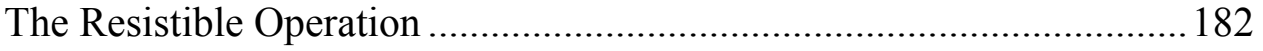

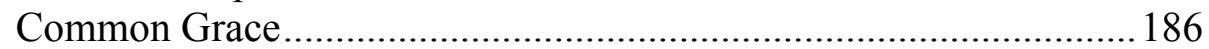

The Internal Operation ............................................................... 188

The External Operation ................................................................ 191

Summary and Conclusion.................................................................. 195

5. PREVENIENT GRACE IN ARMINIUS'S THEOLOGY II ............................200

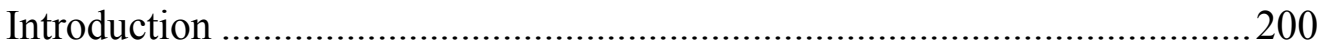

Prevenient Grace: The Universal Work of the Holy Spirit .........................201

Universal Language of Prevenient Grace in the Christian

Theological Tradition .................................................................202

God's Character: Love and Justice ..................................................204

The Extent of the Atonement ..............................................................208

The Universality of the Divine-Human Covenant................................213

The Extent of the Battle between the Spirit and the Flest in

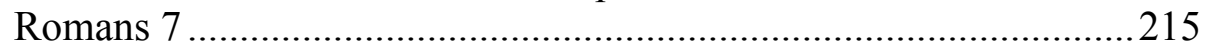

The Universality of Vocation .........................................................224

The Extent of the Special Operation of the Holy Spirit ........................2225

Prevenient Grace and Divine Foreknowledge and Election .........................235

The Spiritual Result of Prevenient Grace: Regeneration and Faith.............. 251 
Prevenient Grace as Organizing Principle in Arminius's Soteriology ..........261

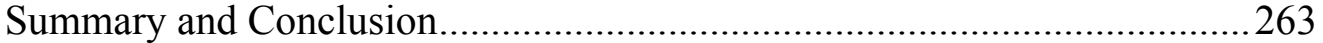

6. CONCLUSIONS AND RECOMMENDATIONS ...........................................267

Suggestions for Further Studies in Arminius ........................................ 272

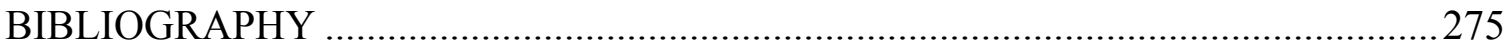




\section{LIST OF ABBREVIATIONS}

Apology. Apology against Thirty-One Articles, Arminius

Art. Certain Articles to be Examined, Arminius

CCL Corpus Christianorum, Series Latina

Concordia Concordia, Louis de Molina

Decl. Sent. Declaration of Sentiments, Arminius

DHT Dictionary of Historical Theology

Gomarus Exam. Examination of Gomarus Theses, Arminius

Hippolytus Lett. Letter to Hippolytus A. Collibus, Arminius

Institutes Institutes of the Christian Religion, John Calvin

Junius Conf. Conference with Junius, Arminius

NPNF Nicene and Post-Nicene Fathers

Opera Arminius, Opera Theologica, $1^{\text {st }}$ ed. (1629)

Orat. $1 \quad$ Oration 1: Object of Theology, Arminius

Orat. 2 Oration 2: Author and End of Theology, Arminius

Orat. 3 Oration 3: Certainty of Sacred Theology, Arminius

Orat. $4 \quad$ Oration 4: Priesthood of Christ, Arminius

Orat. $5 \quad$ Oration 5: Reconciling Religious Dissentions, Arminius

Oration Bertius on the Life and Death of Arminius

Perkins Exam. Examination of Perkins Pamphlet, Arminius

Priv. Disp. $\quad$ Private Disputation, Arminius 
PRRD Post-Reformation Reformed Dogmatics, 4 vols. (2003)

Pub. Disp. $\quad$ Public Disputation, Arminius

Quest. Nine Questions, Arminius

Rom. IX. Analysis of Romans IX, Arminius

Rom. VII. Analysis of Romans VII, Arminius

ST Thomas Aquinas, Summa Theologiae

Trent. Canons and Decrees, Council of Trent

Works The Works of James Arminius, London Edition (1825-1875; reprint:

Baker, 1996)

Works-II The Works of James Arminius, Nichols/Bagnall (1853)

WTJ Westminster Theological Journal 


\section{ACKNOWLEDGMENTS}

Expressing gratitude to those people who have in a variety of ways helped me in the usually long and challenging process of completing a doctoral degree comes with the risk of forgetting certain individuals. So, to the large number of persons involved in any way in my program, thank you for your contributions and encouragement. Nevertheless, I wish to express my recognition to the following individuals and institutions.

To God my Creator, Provider, and Savior. During these years God has provided in all kinds of meaningful ways to support my family and my study journey.

To my wife, Keila, who merits a particularly prominent mention for faithfully and patiently supporting and encouraging me. She kept her beautiful smile even though she had to work long hours and stay home alone with our boys while I was reading and writing in the library.

To my boys, Abner Jasiel and Andy Josias, who joyfully and without complaint gave me time and space for my long hours of writing. You and Mom sacrificed the most.

To my father and mother, Francisco and Mercedes, who guided me in the Christian faith and a life of integrity. Thank you for always keeping me in your prayers. And to my brother, Abdiel, whose pastoral ministry is a continual remainder to me of the model of a Christian and Adventist pastor.

To my chair, Dr. Jerry Moon, whose gentleness, academic advice, and support in my studies and professional formation brought me through the progression of 
academic growth. The provocative ideas, directions, and corrections that Dr. Moon provided during the study of this topic proved to be invaluable. To other members of my doctoral committee, Drs. Martin Hanna and John Reeve, who offered helpful guidance and corrections during the writing of this dissertation. Special thanks to Dr. Miller, who went far beyond his responsibilities as a fourth member of my committee with his useful comments, ideas, and guidance. Dr. Keith Stanglin also deserves my gratitude for agreeing to evaluate my work and for providing insightful suggestions and corrections to improve the present dissertation and my future research on Arminius's theology.

To Dr. Thomas Shepherd, who as director of the PhD program continually provided guidance, encouragement, and opportunities for me to network with other scholars.

To my friends and former professors, Dr. Tevni Grajales, who kindly read all my drafts and provided encouragement and important ideas. To Dr. Ruben MunozLarrondo, who helped me in diverse ways and empathically listened to my ideas, and to Dr. Victor Figueroa, who introduced me to the world of biblical and theological thinking.

To Ulrike Guthrie, my editor, who patiently corrected and improved my English to produce a readable work.

Finally, to Universidad de Montemorelos, Mexico; the Inter-American Division, Andrews University, and the Hispanic Theological Initiative for providing financial resources and other kinds of support without which it would not have been possible for me to complete my doctoral program and this dissertation.

\section{Soli Deo Gloria}




\section{CHAPTER 1}

\section{INTRODUCTION}

\section{Background to the Study}

Without doubt, Jacobus Arminius (1559-1609) was a controversial figure within the Reformed tradition in the second half of the sixteenth century. His appointment as professor of theology at the University of Leiden early in 1603 provoked both strong opposition and fervent support among professors and authorities of the Faculty of Theology.

A main matter of concern was Arminius's view on Romans $7 .{ }^{1}$ Franciscus Gomarus, professor at Leiden since 1594, stigmatized Arminius's interpretation as Pelagianism in much the same way that Petrus Plancius had done in Amsterdam. ${ }^{2}$ Essentially, like Plancius before him, Gomarus believed that Arminius's position openly

${ }^{1}$ See Carl Bangs, Arminius: A Study in the Dutch Reformation (Eugene, OR: Wipf and Stock, 1985), 231-238; Caspar Brant, The Life of James Arminius, trans. John Guthrie (London: Ward and Lang Adamson, 1854), 95-117.

${ }^{2}$ Petrus Plancius, a minister at Amsterdam, reacted to Arminius's position on Romans 7. He believed that Arminius's idea contradicted the teaching of the Reformed tradition on this point. See, Brant, Life of Arminius, 41-43; Carl Bangs, Arminius, 138152. 
contradicted the Heidelberg Catechism and the mainstream thinking in the Reformed tradition. $^{3}$

In Gomarus's view, Arminius's identification of the human beings in Romans 7 as an unregenerate individual granted too much power to the human will. Gomarus and other ecclesiastical authorities reasoned that if an unregenerate individual could struggle with sin as in the Pauline descriptions of Romans 7, this clearly undermined the Reformed teaching of total depravity. Not so, said Arminius, and asserted that humans were naturally depraved and therefore needed the ongoing converting and transforming grace of the Holy Spirit to be able to respond to God. ${ }^{4}$ Nevertheless, Arminius continued to defend the idea that humans are not unwilling participants in the salvific process. He insisted that their freedom of will must consent with God. ${ }^{5}$

The discussions generated from these conflicting views were only the initial point of an extended theological battle that endured until Arminius's death in 1609, the repercussions of which continue to this day. In order to clarify the problem addressed here, I begin by presenting Arminius's views on the topics of total depravity, freedom of the will, and prevenient grace.

${ }^{3}$ Ronald V. Huggins presents a good summary of the major issues in this conference and the principal concerns of Gomarus against Arminius's ideas. See "Romans 7 and the Ordo Salutis from Arminius to Ironside (1591-1928): With Special Emphasis on the American Revivalist Tradition in its Trans-Atlantic Connection" (PhD diss., Wycliffe College and Toronto University, 1996), 21; Bangs, Arminius, 140-141.

${ }^{4}$ James Arminius, The Works of James Arminius, trans. James and William Nichols (Grand Rapids, MI: Baker Book House, 1986), Pub. Disp. XI, 2:189-196; Priv. Disp. XXXI, 2:374-375, Art. XI, 2:716.

${ }^{5}$ Pub. Disp. XI, in Works, 2:194-195. 
Arminius described original sin as "absence of original righteousness ..., that which alone is sufficient to commit and produce any actual sin whatsoever." ${ }^{, 6}$ Total depravity and inability, according to the Dutch reformer, include bondage of all spiritual and moral capacities bestowed on humans by God, even freedom of will. Arminius affirmed "that the mind of [animalis] a natural and carnal man is obscure and dark, that his affections are corrupt and inordinate, that his will is stubborn and disobedient, and that the man himself is dead in sins."7

Focusing on the principal accusation against his views - the apparent power of human will ${ }^{8}$ - he adamantly denied that the will had any capacity in spiritual matters. He stated that "the free will of man towards the true good is not only wounded, maimed, infirm, bent, and [attenuatum] weakened; but it is also [captivatum] imprisoned, destroyed, and lost." ${ }^{\prime 9}$ These remarks appear to demonstrate that Arminius was in full

${ }^{6}$ Priv. Disp. XXXI, in Works, 2:375. However, Arminius tried to avoid the use of the concept "original sin," preferring to talk in terms of "total depravity."

${ }^{7}$ Hippolitus Lett. in Works, 2:700. I have drawn my observations about Arminius's concept of original sin and total depravity from the works of Arminius translated into English. However, recently, Keith D. Stanglin published a series of missing public disputations penned by Arminius. Among these disputations there are two of essential importance for the study of these concepts in Arminius's thinking: Disputatio XXXI De Lapsu Primi Hominis, and Disputatio XXXII De Peccato Originali. See, Keith D. Stanglin, The Missing Public Disputations of Jacobus Arminius, ed. Wim Janse (Leiden, Netherlands: Brill, 2010), 201-217.

${ }^{8}$ Decl. Sent. in Works, 1:659-660.

${ }^{9}$ Pub. Disp. XI, in Works, 2:192. 
agreement with Reformed tradition and theology regarding the tremendous impact of sin on human nature. ${ }^{10}$

However, Arminius also pointed out the participation of the human will in the process of salvation. In his opinion, individuals are free and able to accept or reject the divine calling to salvation. Quoting Bernardo's work De libero arbitrio et gratia that affirms "no one, except God, is able to bestow salvation; and nothing, except free will, is capable of receiving it," ${ }^{, 11}$ Arminius seems to concede a role for both the grace of God and the will of humans in salvation. ${ }^{12}$ Such an assertion was completely erroneous and heretical to Gomarus and Johannes Kuchlinus. Gomarus stressed "that God makes unwilling people into willing people," while Kuchlinus pointed out "that God distributes the Holy Spirit to whomever he will, not as people will. ${ }^{13}$ In contrast to Arminius, they denied any participation of a freed human will in the acceptance of the gospel.

It is on this particular point- the concession of a role to the human will in the process of salvation - that Arminius has been widely criticized. Calvinists have vociferously repeated that according to Arminius humans have an "unblemished

${ }^{10}$ For a general review of Calvin and Reformed theology on total depravity and freedom of will. See Michael Horton, For Calvinism (Grand Rapids, MI: Zondervan, 2011), 35-52.

${ }^{11}$ Pub. Disp. XI, in Works, 2:196.

12 See in particular Arminius's examination of William Perkins's treatise concerning predestination and divine grace, Perkins Exam., in Works 3:249-484.

${ }^{13}$ Keith Stanglin, Arminius on the Assurance of Salvation: The Context, Roots, and Shape of the Leiden Debate, 1603-1609 (Leiden, the Netherlands: Brill, 2007), 79. 
integrity" 14 of their free will with an inner ability to move toward God and rectitude.

They seem to misunderstand Arminius by not considering his declarations about freedom of will in a proper and balanced relationship with the grace of God.

Arminius noted that his opponents discovered an apparent anthropological tension in his theological argumentations on total depravity and freedom of will. However, for Arminius, there was not any contradiction. For him, the real issue was to understand the role of divine prevenient grace in human responsiveness to God. Both Gomarus and Kuchlinus overlooked this central point. ${ }^{15}$ For Arminius, the controversy could be concluded by clarifying a simple question: By what means does the depraved person acquire some freedom of will in order to answer to the divine offer of salvation? The answer, according to Arminius, is that it is the work of the Holy Spirit through divine prevenient grace. Therefore, human responsiveness to God comes not out of an unbound free will, but out of prevenient grace, said Arminius.

In spite of its specific importance for Arminius's theology, the doctrine of prevenient grace has received little attention among Arminian scholars. ${ }^{16}$ Most studies on Arminius have focused on the controversial topic of divine election. Yet while considering the general theological features of divine grace in Arminius's writings, some of these studies do include seminal reflections on prevenient grace. For instance, John M.

${ }^{14}$ Robert A. Peterson and Michael D. Williams, Why I Am Not an Arminian (Downers Grove, IL: InterVarsity, 2004).

${ }^{15}$ See Stanglin, Arminius on Assurance of Salvation, 77-82.

${ }^{16}$ See Peterson and Williams, Why ... Not an Arminian, 176; Roger E. Olson, Arminian Theology: Myth and Realities (Downers Grove, IL: InterVarsity, 2006), 181. 
Hicks, William G. Witt, Keith D. Stanglin, Thomas H. McCall, Robert E. Picirilli, Carl Bangs, and Roger Olson ${ }^{17}$ generally seem to agree that prevenient grace refers to the internal work of the Holy Spirit in the unregenerate individual that creates the possibility for an individual to believe and answer freely to God's offer of salvation. Nevertheless, these scholars do not completely clarify the precise nature and role of prevenient grace, nor the continuity and discontinuity of this doctrine within the history of Christian tradition in the writings of Arminius.

\section{State of Scholarship}

A new interest in and a revival of Arminius's scholarship have produced both new scholarly and popular literature. Most of this new literature is focused on the issue of predestination, election, and assurance of salvation. Some is more general, and analyzes Arminius and Arminianism more broadly. Because there is no major work on Arminius's theology of prevenient grace, here I would like to review some of the most significant works that discuss the concept of prevenient grace.

The awakening of modern scholarship to Arminius owes a great deal to Carl Bangs. In his book Arminius: A Study in the Dutch Reformation, Bangs uncovers the

${ }^{17}$ John M. Hicks, "The Theology of Grace in the Thought of Jacobus Arminius and Philip Van Limborch: A Study in the Development of Seventeenth-Century Dutch Arminianism" (PhD diss., Westminster Theological Seminary, 1985), 41-64; William G. Witt, "Creation, Redemption and Grace in the Theology of Jacob Arminius" (PhD diss., Notre Dame University, 1993), 625-632; Keith D. Stanglin and Thomas H. McCall, Jacob Arminius: Theologian of Grace (New York: Oxford University Press, 2012), 15157; Robert E. Picirilli, Grace, Faith, Free Will-Contrasting Views of Salvation: Calvinism and Arminianism (Nashville, TN: Randall House, 2002), 153-160; Bangs, Arminius, 212-215; R. Olson, Arminian Theology, 141-181. 
historical Arminius in his social, political, and theological world. Although the work is primarily biographical, Bangs summarizes some of the key theological concepts of Arminius's theology. For Bangs, grace is critical for Arminius's concept of sin, free will, and salvation. "The entire process of believing," he argues, results from the working of the prevenient grace of God in the human heart. ${ }^{18}$ Indeed, Bangs corrects previous Arminian scholars like H. Orton Wiley and John Miley for presenting Arminius as a synergist in which the ability of the human will to cooperate with grace is closely related to "a general human capacity." Instead, says Bangs, Arminius believed that prevenient grace illuminates and regenerates the human will resulting in cooperation with grace, meaning the acceptance of God's prevenient grace. ${ }^{20}$ However, Bangs does not explicitly discuss the nature and role of prevenient grace in Arminius's theology. He also does not explore the probable theological sources of this idea in Arminius.

John Mark Hicks in his dissertation The Theology of Grace in the Thought of Jacobus Arminius and Philip van Limborch: A Study in the Development of SeventeenthCentury Dutch Arminianism, discusses prevenient grace in the context of the operation of grace. Hicks argues that prevenient grace in Arminius is always sufficient, and it operates without the participation of human will. According to Hicks, this underlines "the passivity of man in prevenient (sufficient, primary, operating) grace." ${ }^{21}$ Interestingly,

${ }^{18}$ Bangs, Arminius, 341.

${ }^{19}$ Ibid., 342 .

${ }^{20}$ Ibid., 341 .

${ }^{21}$ Hicks, "Theology of Grace in . . . Jacobus Arminius," 58. 
Hicks argues against a universal giving of prevenient grace in Arminius's theology. ${ }^{22}$ Instead, says Hicks, Arminius believed that wherever the word is preached prevenient grace is granted to all the hearers. ${ }^{23}$ Similar to Bangs, Hicks suggests that Arminius restricts the cooperation of human will with prevenient grace in particular and grace in general only to "reception, approval or concurrence." ${ }^{24}$ Therefore, Arminius supports an individual's participation in the acceptance of prevenient grace in which the "free will is not a concurrent cause of grace in salvation." 25 Hicks concludes his consideration of prevenient (sufficient or operating) grace by dissociating Arminius from what he calls "some kind of Melanchthonian synergism, and from the late Medieval synergism of Occam and Biel. ${ }^{26}$ Though Hicks points to important aspects of the concept of prevenient grace in Arminius's theology, he does not completely and systematically address the nature and role of this idea in Arminius. He also fails to explore properly Arminius's connections with Reformation theologians, Reformed divines, and medieval scholastic theologians.

Richard A. Muller, in his book God, Creation, and Providence in the Thought of Jacob Arminius: Sources and Directions of Scholastic Protestantism in the Era of Early Orthodoxy does not discuss Arminius's concept of prevenient grace extensively,

${ }^{22}$ Hicks, "Theology of Grace in . . Jacobus Arminius," 60-63.

${ }^{23}$ Ibid., 62-63.

${ }^{24}$ Ibid., 64 .

${ }^{25}$ Ibid., 65 .

${ }^{26}$ Ibid. 
reserving his discussion of it to link it with the thought of Louis de Molina and other Catholic scholars. ${ }^{27}$ Similarly, in his article "Arminius and Arminianism" in the Dictionary of Historical Theology he links Arminius's doctrine of prevenient grace to that of Gabriel Biel. Such conclusions demonstrate Muller's interest in discovering Arminius's theological sources, which were often in medieval scholasticism. In Muller's view, not only do Arminius and Biel agree that prevenient grace is "offered to all and is not irresistible," but more significantly Arminius's emphasis that "who does what he can by the primary grace already conferred upon him' will receive from God further grace" is identical to Gabriel Biel's maxims that "'to those who do what is in them, God will not deny grace." ${ }^{28}$ Thus, Muller effectively correlated Arminius's doctrine of prevenient grace with medieval semi-Pelagianism. In a similar way, Raymond A. Blacketer, using Muller's assumption that grace is imbued in nature, determines that prevenient grace is an integral part of the created order. ${ }^{29}$ Likewise, J.V. Fesko argues that Arminius's use of the concept of prevenient grace is akin to that of Biel and other scholastic theologians and

${ }^{27}$ Richard A. Muller, God, Creation, and Providence in the Thought of Jacob Arminius: Sources and Directons of Scholastic Protestantism in the Era of Early Orthodoxy (Grand Rapids, MI: Baker, 1991), 163, 255.

${ }^{28}$ Richard A. Muller, "Arminius and Arminianism" in The Dictionary of Historical Theology, ed. Trevor A. Hart (Grand Rapids, MI: Eerdmans, 2000), 34; Richard A. Muller, "Grace, Election, and Contingent Choice: Arminius's Gambit and the Reformed Response" in The Grace of God, the Bondage of Will: Historical Perspectives on Calvinism, ed. Thomas R. Schreiner and Bruce A. Ware (Grand Rapids: Baker, 1995), 2:261.

${ }^{29}$ Raymond A. Blacketer, “Arminius's Concept of Covenant in Its Historical Context," Dutch Review of Church History/Nederlands Archief Voor Kerkgeschiedenis 80, no. 2 (July 2000), 207. 
not a genuine or novel contribution to Reformed or Protestant theology. ${ }^{30}$ Indeed, I will argue from the implication of Fesko's conclusions that because prevenient grace is closely related to the medieval teaching of facientibus, it "falls into a semi-Pelagian category." ${ }^{31}$ Muller and Fesko do not discuss the nature and role of prevenient grace extensively, but they do explore succinctly the most likely sources of Arminius's doctrine of prevenient grace, connecting him with medieval Catholicism rather than with the conclusions of Reformed and Protestant theology.

William Gene Witt briefly explores the concept of prevenient grace in his dissertation Creation, Redemption, and Grace in the Theology of Jacob Arminius. Witt says that for Arminius prevenient grace is the divine answer to human sinfulness. ${ }^{32}$ Prevenient grace helps individuals to deal with the substantial evil and natural effects of both original sin and of actual sins in the human will. Such grace gives individuals the necessary strength or regeneration to counter their sinful nature. ${ }^{33}$ Prevenient grace is a universal gift that operates through the divine act of vocation (preaching of the word) in all human beings. Witt also sees the operation of prevenient grace in repentance and faith, but I will argue that repentance and faith should not be considered an integral part of

\footnotetext{
${ }^{30}$ J. V. Fesko, “Arminius on Facientibus Quod In Se Est and Likely Medieval Sources," in Church and School in Early Modern Protestantism: Studies in Honor of Richard A. Muller on the Maturation of a Theological Tradition, ed. Jordan J. Ballor, David S. Sytsma, and Jason Zuidema (Leiden, The Netherlands: Brill, 2013), 356.

${ }^{31}$ Ibid.

${ }^{32}$ Witt, "Creation, Redemption, and Grace," 625.

${ }^{33}$ Ibid., 628.
} 
prevenient grace, but simply the resulting spiritual gift provided the will does not resist. ${ }^{34}$ Witt does not explore the sources of this concept in Arminius. But, he actually distances Arminius from Pelagian's teachings. He also does not offer a comprehensive analysis of the nature and role of prevenient grace in Arminius's writings.

Though Evert Dekker in his book Rijker dan Midas: Vrijheid, genade en predestinatie in de theologie van Jacobus Arminius (1559-1609) [Richer than Midas: Freedom, Grace, and Predestination in the Theology of Jacobus Arminius (1559-1609)] does not deal directly with the concept of prevenient grace, he does explore Arminius's teaching on grace. It seems to me that some of his ideas ultimately describe Arminius's concept of prevenient grace. Dekker says that the operation of [prevenient] grace is resistible because God's omnipotence does not force the acceptance of salvation. Rather, prevenient grace is a soft and sweet divine touch. ${ }^{35}$ According to Dekker, Arminius's prevenient grace should be more accurately be called "sufficient grace." All humans universally receive sufficient grace, but it is not enough for the acceptance of salvation. The totality of grace is sufficient [prevenient] grace plus efficacious grace, or sufficient grace plus an extra portion equal to efficacious grace. ${ }^{36}$ For Dekker, this is determined by God's foreknowledge, on the basis of which every human being is either under God's providence [prevenient grace] because he or she has rejected that grace, or under God's

${ }^{34}$ Witt, “Creation, Redemption, and Grace,” 630-632.

${ }^{35}$ Evert Dekker, Rijker dan Midas: Vrijheid, genade en predestinatie in de theologie van Jacobus Arminius 1559-1609 (Zoetermeer, The Netherlands: Uitgeverij Boekencentrum B.V., 1993), 165.

${ }^{36}$ Ibid., 166. 
predestination because he or she has accepted that grace.$^{37}$ Dekker also understands that the [prevenient] grace is universal, but this does not mean that every human being experiences the working of the Holy Spirit in their heart; by universal Dekker understands grace to be available wherever the Gospel is preached. Those who have not heard the preaching of the word are rejected. ${ }^{38}$

Robert E. Picirilli in his book Grace, Faith, Free Will: Contrasting Views of Salvation, Calvinism and Arminianism describes prevenient grace in Arminius's theology as the work of the Holy Spirit that "precedes regeneration." ${ }^{, 39}$ In order to avoid the anachronistic and probable misunderstandings of the word prevenient, he suggests the use of new terminology like "enabling grace" or "pre-regenerating grace" to describe the working of this divine action in salvation. According to Picirilli, for Arminius, prevenient grace operates in the human mind by "persuasion" rather than by exerting irresistible force. ${ }^{40}$ Conviction and enabling are also essential elements of prevenient grace. These two characteristics point to the power of the Holy Spirit in opening the understanding of the human mind and reversing the bondage of the human will to give all individuals the opportunity to comprehend and accept the gospel ${ }^{41}$ For that reason, Picirilli argues that prevenient grace in Arminius "is so close to regeneration that it inevitably leads to

${ }^{37}$ Dekker, Rijker dan Midas, 164.

${ }^{38}$ Ibid., 167.

${ }^{39}$ Picirilli, Grace, Faith, Free Will, 153.

${ }^{40}$ Ibid., 153, 155, 157.

${ }^{41}$ Ibid., 155, 157. 
regeneration unless finally resisted."42 According to Picirilli, for Arminius this enabling (prevenient) grace is the initial step in the order of salvation. ${ }^{43}$ Picirilli does not endeavor to discuss the continuity or discontinuity of Arminius's doctrine of prevenient grace with Reformed and Protestant theology. He also does not completely systematize this doctrine in Arminius's theology, and sometimes he combines Arminius's concept with what seem to me to be his own ideas from biblical passages.

Roger Olson makes a significant contribution to Arminian theology with his wellknown work Arminian Theology: Myths and Realities. Olson does not focus primarily on Arminius's theology itself, but on Arminian theology in general. Yet to my mind he accurately introduces Arminius's ideas and contributions as the father of Arminianism in every topic under consideration. Olson regards prevenient grace as an essential element of Arminius's and Arminian theology. He boldly says that prevenient grace is the "distinctive doctrine of Arminianism." 44 I agree with Olson and hope to demonstrate that prevenient grace is the organizing principle in Arminius's own soteriology. Olson, like Picirilli, argues that prevenient grace is both persuasive as well as enabling of the human will. The first and most important work of prevenient grace is to liberate the will. This new freedom results not in a free will but in a "freed" will. ${ }^{45}$ In this regard, unlike

${ }^{42}$ Picirilli, Grace, Faith, Free Will, 154.

${ }^{43}$ Ibid., 160.

${ }^{44}$ R. Olson, Arminian Theology, 159. See also, R. Olson, Arminianism FAQ: Everything You Always Wanted to Know (Roger E. Olson, 2014), 1.

${ }^{45}$ R. Olson, Arminian Theology, 164. 
Picirilli, Olson speaks of a new "intermediate stage" in which humans are "neither unregenerate nor regenerate, but perhaps post-unregenerate and pre-regenerate" ${ }^{, 6}$ - an idea that I do not find in Arminius's writing. Although Olson suggests that prevenient grace is universal, he also argues that for Arminius prevenient grace tended to be restricted to where the Gospel is preached. ${ }^{47}$ In this way, Olson circumscribes prevenient grace as occurring only in connection with the preaching of the Word. By contrast, my reading of Arminius suggests that he believed that there is something universal about prevenient grace, beyond the context of Christianity, thanks to the salvific actions of the Holy Spirit. Olson does not deal with the sources of Arminius's doctrine of prevenient grace.

To my mind, Keith Stanglin is currently the leading scholar in the revival of Arminius's scholarship. Although Stanglin in his dissertation does not specifically address the concept of prevenient grace, much less its sources in Arminius's theology, he clearly disputes Muller and Fesko's conclusions regarding the medieval origin of the facientibus in Arminius. It is precisely because of prevenient grace that Arminius's use of the facere quod in se est is distinct from the medieval sources such as Gabriel Biel and others. ${ }^{48}$ This opens the opportunity for this dissertation to explore the continuity of Arminius's doctrine of prevenient grace with Reformed and Protestant sources or to

${ }^{46}$ R. Olson, Arminian Theology, 164-165.

${ }^{47}$ Ibid., 167. David Eugene Eaton defends a similar view in Arminianism in the Theology of John Wesley (PhD diss., Drew University, 1988), 72.

${ }^{48}$ Stanglin, Arminius on the Assurance, 83. 
validate Muller and Fesko's claims. More recently, Stanglin co-authored Jacob Arminius:

Theologian of Grace with Thomas H. McCall. There they explore more extensively the concept of prevenient grace in Arminius's theology, in particular suggesting some antecedents of this idea in the history of Christian doctrine, such as in Augustine, the Council of Orange, and Thomas Aquinas. Interesting, all these sources are Catholic precedents, but there is no mention of Reformed or Protestant antecedents. ${ }^{49}$ They also claim that prevenient grace initially operates monergistically by coming to the door of the soul and gently calling for human acceptance. I agree that God's prevenient grace operates unavoidably and monergistically in the human heart, but I suggest it does so not just by knocking at the door, but also by restoring the human ability to use freedom of will. They seem to see this restoration of the will as part of subsequent grace and not of prevenient grace. ${ }^{50}$ Besides this, they do not present novel ideas about the concept of prevenient grace except to emphasize the resistibility of grace. ${ }^{51}$

To conclude this review of scholarly analysis of the concept of prevenient grace, I would like to pay attention to the most recent work to focus specifically on the concept of prevenient grace: W. Brian Shelton's Prevenient Grace: God's Provision for Fallen Humanity. ${ }^{52}$ This work is the only detailed and cogent work that I know that specifically

${ }^{49}$ Stanglin and McCall, Theologian of Grace, 153-154.

${ }^{50}$ Ibid., 155.

${ }^{51}$ Ibid., $156-157$.

${ }^{52}$ W. Brian Shelton, Prevenient Grace: God's Provision for Fallen Humanity (Wilmore, KY: Francis Asbury Press, 2014). 
investigates the concept of prevenient grace from a historical, systematic, and biblical point of view and from an Arminian perspective. Indeed, Shelton calls Arminius and Wesley the "artisans of prevenient grace." ${ }^{, 53}$ Unfortunately, he dedicates only two pages to Arminius's concept of prevenient grace and in these makes only general assertions regarding the universality and gracious nature of prevenient grace. ${ }^{54}$ For this reason, perhaps, he wrongly claims that "Arminius did not thoroughly develop his credence in prevenient grace; it was more of a broad attempt to synthesize the biblical notion of free will with passages on divine sovereignty and causation.. ${ }^{, 55}$ With this declaration, Shelton reinforces the idea that Arminius's soteriology makes freedom of will rather than prevenient grace its central concept. Shelton, however, does extensively explore the idea in the history of Christian doctrine. He considers supporters and detractors of prevenient grace theology from Irenaeus to twentieth-century theologians like Richard Niebuhr and Emil Brunner. Nevertheless, he omits critical figures like Melanchthon and the radical reformers. It is important to note that Shelton does not explore the way in which these precedent theological voices influenced Arminius in his conceptualization of prevenient grace.

${ }^{53}$ Shelton, Prevenient Grace, 99.

${ }^{54}$ Ibid., 118-120.

${ }^{55}$ Ibid., 92. 


\section{Problem Statement}

This dissertation addresses the problem of the lack of agreement among interpreters of Arminius concerning the nature, sources, development, and roles of prevenient grace in Arminius's soteriology. Though scholars of Arminius have demonstrated the centrality of grace (in general) in Arminius's theology, they disagree about the sources of the concept of prevenient grace, the extent of the universality of prevenient grace, and the nature of the concept of prevenient grace. Some of those studies seem to imply that Arminius gave the concept of grace equal importance to the concept of freedom of will. Reformed theologians, however, argue that Arminius's main concern was to elevate human freedom of will to a place of prominence in his soteriology. As a consequence, they also contend that Arminius's concept of prevenient grace was in discontinuity with the Reformed and Protestant theological tradition. They claim that the way in which Arminius used the concept was akin to the Catholic conceptualization of prevenient grace rather than that of Reformed or Protestant thinking.

\section{Research Questions}

To address this problem properly, it is necessary to answer the following questions: First, what is the actual nature and role of the doctrine of prevenient grace in Arminius's soteriology? That is, how it works and in what ways. Second, what are the more likely historical sources of this concept in his writings? In other words, is Arminius's doctrine of prevenient grace in continuity with Reformed and Protestant soteriology, or medieval catholic tradition, or does he strike out on his own? Third, does Arminius use the terminology of earlier sources in the same way they used it, or does he 
redefine the common terms to express theological concepts that are clearly not found in the earlier sources?

\section{Purpose Statement}

The purpose of this study of historical theology is to investigate, analyze, and define the probable sources, nature, development, and role of the concept of prevenient or "preceding" grace in the theology of Jacobus Arminius (1559-1609). The study attempts to identify the role that prevenient grace plays vis à vis the freedom of will in Arminius's soteriology. In order to understand the development of Arminius's doctrine of prevenient grace, this study considers his own place in the social and intellectual world of his time and the theological sources that most likely stimulated the development of what I suggest is his unique doctrine of prevenient grace.

\section{Thesis Statement}

Arminius placed prevenient grace rather than human free will at the center of his soteriology and developed this doctrine primarily in continuity with Reformed and Protestant theological precedents and frameworks rather than uniquely Catholic sources and views.

\section{Scope and Delimitations}

The present study is delimited in three specific ways. First, this study focuses only on the nature and function of prevenient grace in Arminius's theology. Therefore, it does not attempt to produce a scholarly analysis of his complete theology on the doctrine of salvation. Second, this research focuses specifically on Jacobus Arminius's literary corpus and refers to other authors and works only as these are relevant to an 
understanding of prevenient grace in the writings of Arminius. Finally, the dissertation explores Arminius's theology of prevenient grace in his historical context, the late sixteenth century in the Low Countries, and generally considers the sources which would, most probably, have been available to Arminius at the time, based on which he would have formed his understanding of the doctrine of prevenient grace. In this manner, the study is informed by the social and intellectual background of Arminius's time (15591609), and predominantly notes the influences of his predecessors and contemporaries on his theological development and thinking.

\section{Justification}

Roger Olson, Richard Muller, and Keith Stanglin, currently the chief current expositors among Arminian theologians, claim that the scholarly community has widely ignored and misinterpreted Jacobus Arminius's teaching, purposes, and theology. ${ }^{56} \mathrm{Olson}$ even regrets that well-known theologians, who have been influenced by Arminius's theology, object to being associated with his name and teachings. However, trends in scholarship seem to be moving toward a more detailed acknowledgment and scholarly consideration of Arminius's thinking.

This recent surge of interest in Arminius's theological thinking, led by Keith Stanglin, has been strengthened by the conference Arminius, Arminianism, and Europe at Leiden University, whose findings have been published in Arminius, Arminianism and

${ }^{56}$ Stanglin, Arminius on Assurance of Salvation, 1; R. Olson, The Story of Christian Theology: Twenty Centuries of Tradition and Reform (Downers Grove, IL: InterVarsity Press, 1999), 455; R. Olson, Arminian Theology, 29. 
Europe: Jacobus Arminius (1559/60-1609), and the Arminianism and Adventism Symposium at Andrews University. ${ }^{57}$ One of the main contributions of these conferences has been to make evident several topics in Arminius's theology that are in need of further consideration.

Stanglin suggests a research program of "primary works," for instance the identification of unknown writings by Arminius, and "secondary analyses," the exposition of Arminius's thoughts on "Scripture, Trinity, Christology, sin, anthropology, ecclesiology . . a and eschatology." ${ }^{, 58}$ Stanglin points out that his "list is neither exhaustive nor detailed ${ }^{\prime 59}$ regarding the studies to be considered on Arminius's theology. The present study focuses on one important topic in Arminius's thinking that requires further clarification and systematization, that is, the nature and the role of prevenient grace in his soteriology. This seems to be a necessary study for the following three main reasons:

${ }^{57}$ While the Leiden conference met from October 9-10, 2009 to commemorate the 400th anniversary of the death of Jacobus Arminius, the Andrews' symposium gathered from October 14-16, 2010 to commemorate the 400th anniversary of the Arminian Remonstrance. The Leiden conference papers and contributions have been published in Th. Marius van Leeuwen, Keith D. Stanglin, and Marijke Tolsma, Arminius, Arminianism, and Europe: Jacobus Arminius (1559/60-1609) (Leiden, the Netherlands: Brill, 2009). The papers from the Andrews University Symposium will soon be published in Martin Hanna, Darius Jankiewicz, and John Reeve, eds., Salvation: Contours of Adventist Soteriology (Berrien Springs, MI: Andrews University press, forthcoming).

${ }^{58}$ Keith D. Stanglin, "Arminius and Arminianism: An Overview of Current Research," in Arminius, Arminianism, and Europe: Jacobus Arminius (1559/60-1609), ed. Th. Marius van Leeuwen, Keith D. Stanglin, and Marijke Tolsma (Leiden, the Netherlands: Brill, 2009), 21-24.

${ }^{59}$ Stanglin, "Arminius and Arminianism," 23. 
First, for the theology of Arminius to be consistent, logical, and defensible, his doctrine of prevenient grace is critical. Arminian studies seem to have overlooked this fact. To my knowledge, prevenient grace represented for Arminius an organizing principle that brought congruence to his reading of the biblical evidence of a totally depraved human nature and a freedom to choose the spiritual good. For the Dutch theologian, prevenient grace traces the line between the spiritual ability and inability of human beings in salvation.

Second, although some studies of prevenient grace in Arminius's writings have been done, there is no systematic consideration of the nature and role(s) of prevenient grace in Arminius's theological system. For instance, secondary studies have different opinions about whether Arminius saw prevenient grace as universal or limited; resistible or irresistible; and more essentially, how effective prevenient grace could be in a corrupted human nature.$^{60}$ In addition, most of the studies do not directly take into consideration the function of prevenient grace in the ordo salutis (order of salvation) of Arminius and its relation to calling, faith, regeneration, preaching, and other essential topics of the doctrine of salvation.

${ }^{60}$ Hicks, "Theology of Grace in . . Jacobus Arminius," 43-44, 51-56, 60-64; Witt, "Creation, Redemption, and Grace," 629-632; Bangs, Arminius, 212-216; R. Olson, Arminian Theology, 159-178, 180-181; Picirilli, Grace, Faith, Free Will, 153159; Stanglin and McCall, Theologian of Grace, 151-157; Peterson and Williams, Why. . . Not an Arminian, 173-191; Michael Horton, The Christian Faith: A Systematic Theology for Pilgrims on the Way (Grand Rapids, MI: Zondervan, 2011), 562; Mildred Bangs Wynkoop, Foundations of Wesleyan-Arminian Theology (Kansas City, KS: Beacon Hill Press, 1967), 59. 
Third, it is necessary to make a study of Arminius's theology of prevenient grace that interprets Arminius in his historical and intellectual context. Therefore, this study looks for continuity or discontinuity with Reformed and Protestant soteriology in Arminius's concept of prevenient grace. In this context, it is also necessary to review the history of doctrine of prevenient grace in the antecedent theological voices of Arminius. In this way, this study attempts to discover how Arminius used and redefined previous theological languages and ideas of prevenient grace for his own soteriological constructions.

\section{Methodology and Outline}

I am following an inductive analytical approach to Arminius theological thinking to uncover Arminius's doctrine of prevenient grace. In my methodological approach, the inductive analytical reading of Arminius's documents does not follow a chronological approach, but rather a topical approach in an effort to discover all significant declarations, in their context, that Arminius made concerning prevenient grace and its nature and role. ${ }^{61}$ Thus, my methodology looks not only for specific and clear references to the concept of prevenient grace, but also for the theological language of prevenient grace that is quite abundant in Arminius's writings. This approach involves three critical steps. First, the method looks for answers in Arminius's documents. Therefore, the dissertation interprets Arminius's writings, giving them the opportunity to clarify their

${ }^{61}$ William den Boer has successfully used an analytical approach to Arminius's theological thinking to uncover Arminius's theology on God's justice and love. See God's Twofold Love: The Theology of Jacob Arminius 1559-1609, trans. Albert Gootjes (Göttingen, Germany: Vandenhoeck \& Ruprecht, 2010), 40-41. 
theological notions and languages. In other words, the study will primarily allow Arminius to speak for himself. This is completely indispensable in order to avoid misrepresentation of Arminius's theology and thinking by assuming current theological categories in the reading of the past. ${ }^{62}$

Most of Arminius's writings in Latin were published in Jacobus Arminius, Theological Works. ${ }^{63}$ A great number of his personal and professional letters were published in Amsterdam in $1660 .{ }^{64}$ Additionally, Stanglin recently identified and published several missing public disputations of Arminius. ${ }^{65}$ Despite some doubts about

${ }^{62}$ Richard A. Muller, "Reflections on Persistent Whiggism and Its Antidotes in the Study of Sixteenth-and Seventeenth-century Intellectual History," in Seeing Things Their Way: Intellectual History and the Return of Religion, ed. Alister Chapman, John Coffey, and Brad S. Gregory (South Bend, IN: University of Notre Dame Press, 2009), 135.

${ }^{63}$ Jacobus Arminius and Petrus Bertius and Pre-1801 Imprint Collection (Library of Congress). Iacobi Arminii, Opera Theologica. Lugduni Batavorum, Apud Godefridum Basson, 1629, in the HathiTrust Database, http://hdl.handle.net/2027/dull.ark:/13960/t00010j48 (accessed September 3, 2012). The works of Arminius contained in this Opera Theologica are accessible in English in two principal publications: the original translation of Jacobus Arminius in The Works of James Arminius, trans. James Nichols and William R. Bagnall (Auburn, NY: Derby, Miller and Orton, 1853) and the American reprinted work, Jacobus Arminius, Writings (Grand Rapids, MI: Baker Book House, 1956).

${ }^{64}$ The professional and personal letters of Arminius can be found in Praestantium ac eruditorum virorum epistolae ecclesiasticae et theoloicae, ed. Christian Hartsoeker and Phillip van Limborch (Amsterdam, the Netherlands, 1660).

${ }^{65}$ See Stanglin, Missing Public Disputations. Especially helpful as a guide to Arminius documents is the chronology of Arminius's letters and writings published by Keith D. Stanglin and Richard A. Muller, "Bibliographia Arminiana," in Arminius, Arminianism, and Europe: Jacobus Arminius (1559/60 - 1609), ed. Th. Marius van Leeuwen, Keith D. Stanglin, and Marijke Tolsma (Leiden, the Netherlands: Brill, 2009), $265-290$. 
Arminius's authorship of the public and private disputations, I treat the disputations as genuine professional writings of Arminius. ${ }^{66}$ It seems to me that Arminius's public and private disputations are essentials to understanding his doctrine of prevenient grace.

Second, this methodology also recognizes the great degree of influence that the social, economical, intellectual, and religious contexts exert on theological thinking within the Christian Church. For this reason, this study explores Arminius's life and historical context. As Muller suggests, meaning is to be found in the proper reading of the historical context and the documents. ${ }^{67}$ Arminius's theology of prevenient grace should not be reduced to the intellectual and social context that influenced him. Instead, it is important to exercise careful judgment, especially in the case of Arminius, to note when he abandoned the understanding of his theological background within the Calvinist milieu to construct his own theological system. Consequently, this study will analyze the world in which Arminius penned his theological considerations in close relation with the documents themselves.

Finally, this dissertation recognizes that ideas do not arise in a vacuum. Therefore, doctrinal ideas like prevenient grace, the main focus of this study, have a history that it is theological, biblical, and philosophical. Thinkers are continually influenced by the reflections of their forerunners and contemporaries, even in some measure by those whom they reject or with whom they disagree. Therefore, this study would be incomplete

\footnotetext{
${ }^{66}$ For the discussion regarding the authorship of Arminius's public and private disputations, see den Boer, God's Twofold Love, 23-34; Stanglin, Missing Public Disputations, 43-100; Stanglin, Arminius on the Assurance of Salvation, 47-58.

${ }^{67}$ Muller, "Reflections on Persistent Whiggism," 136-137.
} 
if it did not take into account the probable sources of Arminius's theology of prevenient grace provided by early church, medieval, and his own contemporary thinkers.

Theological influences in Arminius thinking were varied and disparate. Influences of the Early Church Fathers like Augustine of Hippo (354-430), medieval theologians like Thomas Aquinas (1225-1274), Catholic scholars like Francisco Suarez (1548-1617) and Luis de Molina (1535-1600), and Protestant theologians like John Calvin (15091564) and Phillip Melanchthon (1497-1560) are well attested in his writings and in recent scholarly research. ${ }^{68}$ In addition, he was in contact with the most brilliant minds in theological studies of his days, scholars like Theodore of Beza (1519-1605) and several of his partners at Leiden. ${ }^{69}$ This part of the study is important in order to note how Arminius appropriated, used, reacted to, and changed their ideas in the conceptualization of his theology of prevenient grace. In this way, the study will be better able to identify how he developed this doctrine in his own way over time.

${ }^{68}$ Aza Goudriann, “'Augustine Asleep’ or 'Augustine Awake'? Jacobus Arminius Reception of Augustine," in Arminius, Arminianism, and Europe: Jacobus Arminius (1559/60-1609), ed. Th. Marius van Leeuwen, Keith D. Stanglin, and Marijke Tolsma (Leiden, the Netherlands: Brill, 2009), 51-72; Stanglin and McCall, Jacob Arminius: Theologian of Grace, 19, 39, 43, 45, 199; Diana Stanciu, "Re-Interpreting Augustine: Ralph Cudworth and Jacobus Arminius on Grace and Free Will," Zeitschrift für antikes Christentum 11, no. 1 (2007): 96-114; Richard A. Muller, "Arminius and the Scholastic Tradition," Calvin Theological Journal 24, no. 2 (1989): 263-277; Carl Bangs, "Arminius and the Reformation," Church History 30, no. 2 (1961): 155-170; Eef Dekker, "Was Arminius a Molinist," Sixteenth-Century Journal 27, no. 2 (1996): 337-352.

${ }^{69}$ F. Stuart Clarke, “Arminius's Understanding of Calvin,” Evangelical Quarterly 54, (1982): 25-35; Stanglin, Arminius on the Assurance of Salvation, 13; Richard A. Muller, "Arminius and the Reformed Tradition," Westminster Theological Journal 70, no. 1 (2008): 19-48. 
Having presented the methodological steps, it seems useful to present the general design of this study.

Chapter 1, the introduction, reviewed the literature of previous works on Arminius's concept of prevenient grace. It also presented the statements of problem, purpose, thesis, and methodology of this study.

Chapter 2 next explores Arminius historical, social, political and religious context. It also tries to discover the main theological influences in his thinking. The chapter closes by analyzing the person and his life.

Chapter 3 reviews the background of the doctrine of prevenient grace that provides possible sources that may have influenced Arminius's thought in this doctrine.

Chapters 4 and 5 evaluate Jacobus Arminius's theology of prevenient grace in order to define its nature and role as a crucial organizing principle in his writings. In this manner, these chapters clarify the function of prevenient grace in Arminius's soteriology. They explain the interrelationship between Arminius's conception of prevenient grace, corrupted human nature, and freedom of will. They also seek to understand how prevenient grace relates to calling, faith, the preaching of the Word, and the divine law, among other related topics, in the initial process of conversion.

Chapter 6 gives a summary and conclusions that outline the principal findings and their critical implications for Arminian studies. 


\section{CHAPTER 2}

\section{THE LIFE AND WORK OF JACOBUS ARMINIUS}

\section{Historical Introduction}

Jacobus Arminius's life and work is well documented in the biographical works of Caspar Brant and Carl Bangs. ${ }^{1}$ These works rely on the funeral oration delivered by Bertius at Arminius's death. While it is unnecessary to outline his life in detail here, it is nonetheless helpful to note some critical aspects of his life that pertain to his understanding of the doctrine of prevenient grace. My reconstruction is based on recognized secondary sources and on Arminius's writings and letters contained in The Works of Arminius. This account of Arminius's life and historical context, however, is an attempt to understand how the experiences of the man and his world influenced his development of the doctrine of prevenient grace.

I do not mean, however, that every historical detail discussed here directly connects to the theological outcome of prevenient grace in Arminius's writings. But there are instances in Arminius's life and context like the theological context, the diverse

${ }^{1}$ There are several summaries or accounts of Arminius's life in different publications even before the work of C. Bangs that rely on Brant's account. I do not think that it is useful to mention all of them here. For instance see, Geo L. Curtis, Arminianism in History; or, The Revolt from Predestinationism (Cincinnati, $\mathrm{OH}$ : Cranston \& Curts, 1894), 15-50. 
religious influences, and some theological writings that most probably impacted his thinking on the doctrine of prevenient grace. The biographical details presented here also intend to introduce some readers to Arminius before they consider his theology. Furthermore, this chapter also intends to present the way in which I understand the previous biographical accounts of Arminius's life giving me the opportunity to show intances where those accounts differ and to suggest probable solutions to those differences.

In this chapter, I first scrutinize the social, religious, and theological world of Arminius. The study pays special attention to those events, ideas, personalities, and writings that influenced Arminius as a person, pastor, and theologian. Second, after understanding Arminius's historical context, I consider Arminius as an individual in light of his family, patrons, studies, pastoral and academic work, and his last years of controversies over the doctrine of predestination. Second, I explore the public images and the self-image of Arminius to see how others perceived him and how he perceived himself. This is critical for understanding the man and his ideas, both internally and externally. Finally, I briefly explore Arminius's theological method and hermeneutic as a helpful tool for reading and interpreting his doctrinal and religious conceptualizations. All these exploration will show that Arminius was a man of his time, but one who was not completely conformed to the ideas and the world that surrounded him. He found in the Scriptures the impetus and spirit to discover and explore new theological horizons as well as new ways to construct the Christian community. 


\section{The Social, Religious, and Intellectual World of Arminius}

The social, religious, and intellectual world of the late sixteenth-century in Europe surely influenced Arminiu's life and work to some extent. The main purpose of this section is to set Arminius in his historical context. In general, it describes those particular social, religious, and intellectual events and influences with which Arminius was in contact, and which made him a man of his time. Yet in his writings Arminius himself does not give very much indication of how the social reality of his time influenced him, or how he reacted to specific events like the death of his whole family and three of his children, or the struggle between his people and the Spanish troops.

The Social World of Arminius

The social world of Arminius was, like most periods of human history, a convulsed one - a society marked by injustices, political struggles, religious dissensions, and the common activities of human life. Europe in general and the Netherlands in particular were involved in political and religious upheaval. In Arminius's time, society and the Christian Church, as Christine Kooi affirms, lived between two singularities, "the war ... against Spain, that is, the region's partial detachment from the Habsburg imperium, and ... the spread of Protestant Reformation, particularly its Reformed variant." ${ }^{, 2}$ Here, I will pay attention first to the social-political life in Arminius's Netherlands.

${ }^{2}$ Christine Kooi, "The Netherlands," in Reformation and Early Modern Europe: A Guide to Research, ed. David M. Whitford (Kirksville, MO: Truman State University Press, 2008), 273. 
In 1559 Philip II, the Catholic King of Spain, controlled territories from every continent including the Netherlands. The expression "the empire on which the sun never sets" originally referred to the extent of Spain's vast territories. Philip II, like his father Charles V and his grandparents Isabella and Ferdinand, considered himself the protector of the Catholic faith. Prohibitions against freedom of worship, and persecution of those who accepted the Protestant faith, were an integral part of his domestic and foreign policies. He wrote to Luis Requesens y Zúñiga, ambassador in Rome, "you can assure his Holiness that rather than suffer the least injury to religion and the service of God, I would lose all my states and a hundred lives if I had them, for I do not intend to rule over

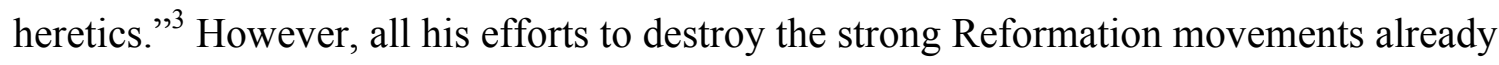
present for decades in the Low Countries proved fruitless.

Since 1565, the leaders of the Low Countries had requested of the Spanish crown more openness, specifically for religious liberty and moderation against dissenting religious voices in the Netherlands. ${ }^{4}$ However, their plea was rejected, leading to widespread violence, iconoclasm, and destruction of Catholic properties, churches, and monasteries. ${ }^{5}$ Accordingly, but belatedly, Philip II reacted in a vindictive fury with a

${ }^{3}$ Quoted in Andrew Pettegree, Europe in the Sixteenth Century (Malden, MA: Blackwell, 2002), 214.

${ }^{4}$ Geoffrey Parker, The Grand Strategy of Philip II (New Haven, CT: Yale University Press, 1998), 119-121.

${ }^{5}$ Parker, Grand Strategy, 121. See also, Geert H. Janssen, The Dutch Revolt and Catholic Exile in Reformation Europe (Cambridge, United Kingdom: Cambridge University Press, 2014), 23-26. 
bloody campaign against the Dutch Revolt. ${ }^{6}$ The famous (or infamous) Duke of Alba or the Iron Duke, Fernando Álvarez de Toledo y Pimentel, led the Spanish troops in years (1572-1579) of war, destruction, and carnage against Dutch civilians, members of the nobility, and Protestant religious leaders. Oudewater, unlike other destroyed cities, was not an important economic, religious, or educational center in the country. However, the city played a central role in the movement of national liberation and the Protestantization of the northern territories that supported the cause of William of Orange. ${ }^{7}$ Consequently, the city experienced the destruction of almost all of its five hundred structures ${ }^{8}$ and the

${ }^{6}$ It is important to highlight that many of the narratives regarding the massacres, pillaging, and atrocities committed by the Spanish troops in the Netherlands come from the perspective of witnesses, second-hand accounts, and historians prone to misrepresentations, exaggerations, and prejudices. For instance, Bangs claims that the Oudewater experience was a carnage unparalleled "even in those bloody days," Arminius, 40; however, Geoffrey Parker, a well-respected historian of Philip II and the Spanish campaigns in the Netherlands asserts in a more balanced account that "by the sixteenthcentury standards, the number of executions was relatively small considering the scale of the troubles. No government at that time voluntarily chose to leave traitors and rebels alive once they were captured. Queen Elizabeth's treatment of the northern rebels after 1569 was no different from Alva's behavior (except that Elizabeth's victims were Catholics and Alva's Protestants)," Philip II (Boston, MA: Little, Brown and Company, 1978), 99. Indeed, Bangs recognizes that at least one of his own sources has the tendency to "dramatize the events with a possible exaggeration of numbers," Arminius, 41. Also, in the religious struggles for power in the sixteenth century between Catholics and Protestants, events like those in Oudewater were unfortunately frequent occurrences. Consequently, there is no reason to doubt the historical facts of the destruction of the city and the murder of many people in the population; however, the extent of the carnage should be doubted, or at least questioned. See also, Janssen, The Dutch Revolt, 20-22.

${ }^{7}$ Bangs, Arminius, 38-39.

${ }^{8}$ W. Stephen Gunter, Arminius and His Declaration of Sentiments: An Annotated Translation with Introduction and Theological Commentary (Waco, TX: Baylor University Press, 2012), 13. 
murder of great numbers of its population. ${ }^{9}$ In this Spanish military crusade Arminius's whole family was killed. ${ }^{10}$

It is important to understand that Philip II's war against the Netherlands was basically driven by religious sentiments against the heretics. Geoffrey Parker argues that to "drive against heresy and non-Catholic" groups was not only the policy of Philip II in the Netherlands but in all his territories. ${ }^{11}$ In the same spirit of his grandparents, Philip II's ultimate goal was the complete destruction in his kingdom of all heretics, idolaters, and false Jew and Moslem converts. Overwhelmed by financial troubles and failures in his war against the infidels, he demonstrated his understanding of divine mission. He said to his secretary, "God will have mercy on us, because the cause is His; and [the thought of] this, and the damage that his religion is suffering, is what causes me most anguish in this matter." ${ }^{\prime 2}$ Therefore, in Philip II's vision, his war against the Dutch heretics was less a desire to retain one of his large territories than, in his opinion, to support and maintain the true Christian faith. Indeed, he saw himself as the divinely appointed protector of the Roman Catholic faith.

${ }^{9}$ Bangs, Arminius, 43.

${ }^{10}$ Ibid., 42.

${ }^{11}$ Parker, Philip II, 99.

${ }^{12}$ Quoted in Parker, Philip II, 125. The personal Christian devotion of Philip II led him ardently to support ardently and enforce religious policies in favor and defense of the Catholic faith; see Parker, The Grand Strategy, 77-109; 115-146 and Geoffrey Parker, Imprudent King: A New Life of Philip II (New Haven, CT: Yale University Press, 2014), 80-99. This is not to say that the Spanish lacked political and economic interests; surely they had both. Likewise, the Dutch also were fighting not only to regain religious liberty, but also for political and economic freedom. 
At that time, Arminius was studying in Utrecht. When he heard the news of the fate of his home town, he immediately decided to return to Oudewater to ascertain what had become of his family. Arminius's reaction to Oudewater and other Spanish massacres in Holland most likely affected his entire life and thought.

Arminius's world was a world of political and social struggle. In other words, the society of Arminius's time was changing rapidly, including its political and religious structures of power. Some European territories long dominated by royalist and foreign powers were fighting for their freedom. In particular, Holland was beginning to enjoy modest independence from Spain after years of war and suffering. However, it still struggled internally with establishing a government, the unification of the country, and issues of national identity.

On one side, John Oldenbarnevelt, prime minister of the United Provinces and faithful supporter of Arminius, and the middle-class oligarchy favored a republican government that was completely independent of Spain but maintained good relations with the former imperial power. On the other side of the political spectrum, Prince Maurice, son of William of Orange and head of the Army, along with the nobility and the peasants favored a sovereign monarchy and desired to continue the war against Spain until they attained independence. Despite the bitter opposition of Prince Maurice, Oldenbarnevelt worked out a peace treaty with Spain at least as a temporary solution to years of war. However, to some extent it did not guarantee Spain's total recognition of Netherlands's 
independence. ${ }^{13}$ In addition, like Arminius, Oldenbarnevelt had a principled vision of religious tolerance for Holland that would at least assure freedom of worship for Catholics, Lutherans, Anabaptists, and later the Remonstrant ministers and believers. ${ }^{14}$ Consequently, he was unfairly accused of being pro-Spain and a traitor. In 1617, Prince Maurice led a military coup and deposed the council members who had Remonstrant and Republican sympathies. In this coup, Oldenbarnevelt and the Remonstrant ministers and politicians confronted prison, bitter persecution, and death. ${ }^{15}$ It seems evident that the sympathies of Arminius sided with Oldenbarnevelt and the merchants in this political affair. One could speculate that if Arminius had been alive at the time of the persecution against the Remonstrants he likely would have died as a martyr of the cause.

The social world of Arminius was closely entwined with the religious reality of the time. Here, for the sake of clarity and in order to point to specific differences I treat

${ }^{13}$ See Jan Den Tex, Oldenbarnevelt: 1606-1619, trans. R. B. Powell, (London: Cambridge University Press, 1973), 2:299-422. The Truce was not popular either in Holland or in Spain. While Oldenbarnevelt forced it in Holland, the archduke forced it upon the Spanish court. See J. P. Cooper, ed., The New Cambridge Modern History: The Decline of Spain and the Thirty Years War 1609-48/59 (Cambridge, UK: Cambridge University Press, 1970), 4:260-267. See also Charles S. McCoy and J. Wayne Baker, Fountainhead of Federalism: Heinrich Bullinger and the Covenantal Tradition (Louisville, KY: Westminster/John Knox, 1991), 66-67; J. P. Heering, Hugo Grotius as Apologist for the Christian Religion: A Study of His Work 'De veritate religionis christianae,' 1640 (Leiden, the Netherlands: Brill, 2004), 2; Justo González, The Story of Christianity, vol. 2, The Reformation to the Present Day (San Francisco, CA: Haper \& Row, 1984), 180.

${ }^{14}$ Den Tex, Oldenbarnevelt, 426, 430; A. T. van Deursen, "The Dutch Republic, 1588-1780" in History of the Low Countries, ed. J. C. Blom and E. Lamberts, trans. James C. Kennedy (New York: Berghahn, 2006), 161.

${ }^{15}$ van Deursen, "The Dutch Republic," 163-167. 
the social and religious world of Arminius separately. Obviously, the social and political struggles of the time greatly influenced the church and the religious conflicts during Arminius's life.

\section{The Religious World of Arminius}

Geert H. Janssen argues that Reformation ideas and ideals encountered a "fertile soil in the Netherlands from the start." ${ }^{, 16}$ Luther's pamphlets circulated in the territory as early as 1520 . Due to the influence of Luther's ideas among the new spiritual ideas and religious practices of the Protestant movement, all dissenting voices and new spiritual practices were termed Lutheran. However, Lutheranism was not widely successful in the Low Countries. ${ }^{17}$ From 1540 on, Calvin's ideas and the Reformed tradition with its distinct ecclesiastical organization, well-prepared ordained ministers, effective use of literature, music, and the Bible, and a well-defined theological system, rapidly became the leading force for Reformation in the country. ${ }^{18}$ Calvinists used impresive methods, like public recitation of biblical texts and preaching and chanting the Psalms, to gain believers and provoke the Catholic establishment. ${ }^{19}$ As a result, the Reformed tradition overrode the influence of the Anabaptist movement that had enjoyed a prevailing

${ }^{16}$ Janssen, The Dutch Revolt, 21.

${ }^{17}$ Joke Spaans, "Reform in the Low Countries," in A Companion to the Reformation World, ed. R. Po-Chia Hsia (Malden, MA: Blackwell, 2004), 119-120.

18 Janssen, The Dutch Revolt, 21; Spaans, "Reform in the Low Countries," 122; Guido Marnef, "The Changing face of Calvinism in Antwerp, 1550-185," in Calvinism in Europe, 1540-1620, ed. Andrew Pettegree, Alastair Duke, and Gilliam Lewis (New York: Cambridge University Press, 1994), 158.

${ }^{19}$ Spaans, "Reform in the Low Countries," 123. 
presence in the country since $1530 .{ }^{20}$ Obviously, Catholicism's religious and political influence was still strong in the Low Countries specifically for the support of the Spanish Empire.

At this point it is important to analyze in more detail Anabaptism in the Netherlands, because it was the most important influence from the 1520s to around 1572. ${ }^{21}$ Anabaptism became a broad and successful Protestant movement in the Netherlands thanks mainly to the influence of Melchior Hoffman. Indeed, Melchiorite Anabaptism "became predominant in some cities and some areas of the Netherlands" especially in Amsterdam, the city in which Arminius would become a pastor about sixty years later. ${ }^{22}$ Anabaptists confronted heavy persecution from the beginning. Hofmann, a Lutheran preacher and pastor but already connected with the Radical reformers, asked for liberty and a place of worship for the Anabaptists. ${ }^{23}$ Although, for some scholars,

${ }^{20}$ George Huntston Williams, The Radical Reformation, 3rd ed. (Kirksville, MO: Truman State University, 1992), 1177. The influence of the Anabaptists was greatly discredited in the eyes of many because of the Münster debacle in 1535. See John D. Woodbridge and Frank A. James III, Church History From the Pre-Reformation to the Present Day: The Rise and Growth of the Church in Its Cultural, Intellectual, and Political Context (Grand Rapids, MI: Zondervan, 2013), 197-198.

${ }^{21}$ Andrew Pettegree, "The Calvinist Church in Holland, 1572-1590," in Calvinism in Europe, 1540-1620, ed. Andrew Pettegree, Alastair Duke, and Gilliam Lewis (New York: Cambridge University Press, 1994), 174-175.

${ }^{22}$ L. Lindeboom, Het Bijbelsch humanisme in Nederland (Leiden, the Netherlands: 1913), 31, quoted in Cornelius Krahn, Dutch Anabaptism: Origin, Spread, Life and Thought 1450-1600 (The Hague, the Netherlands: Martinus Nijhoff, 1968), 119. See also Arnold C. Snyder, Anabaptist History and Theology: An Introduction (Kitchener, Ontario: Pandora, 1995), 144-145.

${ }^{23}$ Krahn, Dutch Anabaptism, 90. Krahn believes that these actions marked the complete identification of Hoffmann with the Anabaptists. 
Hoffmann's imprecise preaching on the use of the sword by believers obscures his pacifist legacy, he always maintained that true Christians would not use the sword. Misunderstanding and misuse of Hoffmann's teaching on the sword and views on eschatology led to the drastic actions at Münster. ${ }^{24}$ Obviously, the tragedy of Münster and local actions like trying to assail and capture towns in the Netherlands by radicalized Anabaptists negatively impacted Anabaptism in the Low Countries, but the Anabaptist movement did not die. ${ }^{25}$ After these tragedies, pacifist Anabaptists like the brothers Dirk and Obbe Phillips and Menno Simons, the true spiritual heirs of Hoffmann,${ }^{26}$ continued as a significant religious force in the Low Countries until the days of Arminius. It remains an open question to what extent the most positive view of Anabaptists about the freedom of will and the role of God's prevenient grace influenced Arminius's conceptualization of prevenient grace.

To this point, our discussion demonstrates that the religious landscape in the Netherlands during Arminius's life and ministry covered a wide spectrum of theological ideas and ecclesiastical practices. This complex mixture of religious ideas and tensions

${ }^{24}$ Because the radical events at Münster under the leadership of Jan Matthijs and his successor Jan van Leiden are well known, it is not necessary to recount them here. For an account of the history of Münster's tragedy, see James M. Stayer, Anabaptists and the Sword (Lawrence, KA: Coronado Press, 1972), 205-280.

${ }^{25}$ Spaans, "Reform in the Low Countries," 121. See also, Alastair Duke, "The Netherlands," in The Early Reformation in Europe, ed. Andrew Pettegree (New York: Cambridge University Press, 1992), 158.

${ }^{26}$ Stayer, Anabaptists, 223. 
was also fertile ground for religious dissension and political struggle, and resulted in mutual persecution and animosity.

It is this religious reality of his time and this spirit of the epoch that Arminius seems to be describing in his oration, On Reconciling Religious Dissensions Among Christians, ${ }^{27}$ delivered at the University of Leiden on February 8, 1606. After poignantly describing the way in which religious dissension seizes and controls the human intellect and emotions, resulting in persecution and efforts to completely exterminate others, he called for loving Christian dialogue, personal submission to God and his Word, and a spirit of tolerance to the different religious sentiments of his time. ${ }^{28}$ In his opinion, intolerance and bitter opposition are an integral part of the spirit of Rome, but are not part of a genuine Christian. Therefore, in the oration, Arminius outlined a program to "assert liberty of conscience and of worship; and then, upon that fundamental principle, to persuade all Christians, however divided in opinion, to lay aside the distinctions of sects

${ }^{27}$ See, Orat. 5., in Works, 1:434-541.

${ }^{28}$ Ibid., 1:447, 468-470, 485-486; 504-514. He says that in some cases the bitterness is such that "rage is excited and cruelty exercised against the reputation, the property, and the persons of the living; against the ashes, the sepulchers, and the memory of the dead; and against the souls both of the living and the dead. Those who differ from the stronger party are attacked with all kinds of weapons; with cruel mockings, calumnies, execrations, curses, excommunications, anathemas, degrading and scandalous libels, prisons and instruments of torture." Ibid., 1:449. Arminius is most probably describing the spirit of the Catholic Middle Ages and Reformation practices of persecution and tortures. However, he was also fully aware of the persecutions of the Anabaptists and dissenters of the Reformed Church. In addition, he worried that the same spirit showed itself among his opponents. 
and party" 29 in favor of a more peaceful and unified Christian spirit and relationship within Christianity.

Indeed, in Arminius's view of tolerance, a view probably influenced by Hoffmann's advocacy for tolerance of Anabaptism in the Netherlands, even Roman Catholics should enjoy the liberty to exercise their religion. He called the Reformed ministers and believers to exercise "Christian charity" in favor of Catholics. Furthermore, he seems to disagree with the practice of some towns and cities that "forced Catholics to attend services of the Reformed, under penalty of fine." ${ }^{30}$ Arminius's attitude regarding religious tolerance especially in favor of Catholics has been interpreted either as a compromise with Roman Catholicism or as a political move to gain the favor of the University's moderate leaders. ${ }^{31}$ Nonetheless, in reading Arminius's writings regarding religious dissensions it seems to me that he had a genuine interest in tolerance and acceptance of fellow Christians despite the doctrinal divide.

Arminius's advocacy of religious tolerance, however, does not mean that he was a promoter of ecumenical ideals; this was obviously a foreign concept in his days. Neither was he open to diluting biblical truth in order to attain Christian unity. In reality, Arminius advocated tolerance because he himself was open to challenging some interpretations of his own tradition. According to Brant, Arminius affirmed that he "was

${ }^{29}$ Nathan Bangs, The Life of James Arminius, D.D., Formerly Professor of Divinity in the University of Leyden (New York: Harper \& Brothers, 1843), 258.

${ }^{30}$ See, Eric H. Cossee, "Arminius and Rome," in van Leeuwen, Stanglin, and Tolsma, Arminius, Arminianism, and Europe, 80.

${ }^{31}$ Cossee, “Arminius and Rome,” 80. 
in no respect bound to every private interpretation of the Reformation, but was plainly free and entitled to expound the heavenly oracles, and particular passages of the sacred volume, according to the dictates of conscience." ${ }^{32}$ Consequently, Arminius expressed his theological ideas and biblical interpretations to correct some doctrinal points of the Reformed tradition but always within the boundaries of his own Reformed Church. In other words, in his contacts with the different streams of Christian religions, Arminius firmly situated himself as a minister of the Reformed tradition.

Accordingly, Arminius in his disputation On the Roman Pontiff and other treatises harshly criticized Roman Catholic doctrines and the papal office for opposing the biblical truth and assuming Christological titles and roles. ${ }^{33}$ Likewise, he expressed points of disagreement with the Lutheran churches, but acknowledged Lutherans as "brethren."34 He also was asked to confront the Anabaptists. This task he did not fully accomplish, not because he fully supported all Anabaptist doctrines, but most probably because he was involved in the dispute over predestination at the time and was also trying to keep up with his teaching responsibilities. In reality, he expressed that the Anabaptist view on predestination was akin to his own conclusions. ${ }^{35}$ However, Arminius actually wrote a

${ }^{32}$ Brant, The Life of James Arminius, 42.

${ }^{33}$ Pub. Disp. XXI, in Works, 2:264-274.

${ }^{34}$ Decl. Sent., in Works, 1:695; Apology, Art. I and II," in Works 1:740; Romans VII., in Works, 2:633.

${ }^{35}$ Letter to Uitenbogardt, dated January 26, 1600, in Works, 1:594-595; Decl. Sent., in Works, 1:640-641. Arminius expressed to his friend that he was also concerned that the task to contest the Anabaptists was given to him in order to uncover his own sentiments, a move that Arminius considered most aberrant for a Christian. 
small public disputation opposing specific Anabaptist teachings like the negation of poedobaptismo [paedo-baptism], the non-participation of Christians in the magistratu [government], and the requirement to avoid any kind of iuramento [oath]. ${ }^{36}$

In sum, Arminius was well aware of the dissensions within Christianity in his day. However, he wanted to avoid futile discussions and disagreements over irrelevant matters and sectarian divisions that naturally occur among humans. Instead, Arminius wanted to concentrate intellectual effort, fruitful conversation, and intense study on settling critical points of doctrine as well as Christian living and worship. For this reason, he said that the distinction of the true "catholic" Church should be based on doctrine, worship, and morality in close consideration of the biblical truth, and not based on traditions and locations. But even in this case, his spectrum for evaluating the different churches is wider and vacillates between the extreme of "orthodox and heretical ... right worshiper and idolatrous ... purer and more impure. ${ }^{, 37}$ The closer one was to the right side of the spectrum, the closer one was to being identified as a true member of the Universal church. In other words, Arminius set the borders of true Christian religion and teachings more broadly than did many of his contemporaries.

\section{The Theological World of Arminius}

The theological world of Arminius in the Netherlands and Europe had been experiencing tremendous changes since the Reformation. Gone were the times when

\footnotetext{
36 “Contra Anabaptistas," in Stanglin, Missing Public Disputations, 575-588.

${ }^{37}$ Priv. Disp. LV, in Works, 2:421.
} 
Christian theology was defined by the Church, the decisions of her councils, and the constructions of her theologians. The protestant principle of sola scriptura in combination with the humanistic motto ad fontes epitomized the renewed reading of the sacred text, the construction of new theological insight, and the transformation of Christian worship, ministry, government, and life. Arminius was completely smitten by this new spirit; after all, he was making his early incursions in theology only about thirtyfour years after Luther's death and sixteen years after Calvin's death.

During his time of studies and indeed throughout his pastoral and teaching career, he was under the influence and formed an integral part of the development of early Reformed orthodoxy and Protestant scholasticism. William J. van Asselt defines Reformed orthodoxy as "the stream of theology that is tied to the Reformed confessional documents. ${ }^{38}$ Muller states that Reformed scholasticism denotes a "common method" shared by Reformers of the sixteenth century in pursuing theological or philosophical questions. ${ }^{39}$ It could therefore not be directly related to a specific "theological result or

${ }^{38}$ Willem J. van Asselt, Introduction to Reformed Scholasticism, Reformed Historical-Theological Studies, ed. Joel R. Beeke and Jay T. Collier; trans. Albert Gootjes (Grand Rapids, MI: Reformation Heritage Books, 2011), 104.

${ }^{39}$ Richard A. Muller, After Calvin: Studies in the Development of a Theological Tradition, Oxford Studies in Historical Theology (New York: Oxford University, 2003), 27; Richard Muller, Post-Reformation Reformed Dogmatics: Prolegomena to Theology: The Rise and Development of Reformed Orthodoxy, ca. 1520 to ca. 1725, 2nd ed. (Grand Rapids, MI: Baker, 2003), 1:35. According to Muller, the common method of scholastic works entails "(1) identifying the order and pattern of argument suitable to technical academic discourse, (2) presenting an issue in the form of a thesis or question, (3) ordering the thesis or question suitably for discussion or debate, often identifying the 'state of the question,' (4) noting a series of objections to the assumed correct answer, and then (5) offering a formulation of an answer or an elaboration of the thesis with due 
philosophical perspective. ${ }^{, 40}$ Muller and van Asselt consider that the natural marker of the beginning of Protestant Scholasticism spanned from the death of the second generation of Reformed theologians like Calvin and German Reformed theologian Wolfgang Musculus, extended to the adoption of the Heidelberg Catechism, and culminated in the Synod of Dort. ${ }^{41}$ Most scholars agree with Muller that one characteristic of this early period was the use of an eclectic methodology that explored a variety of philosophical as well as theological traditions. ${ }^{42}$ This basically means that Reformed theologians willingly used scholastic methods to conceptualize Protestant doctrine and theology exploring theological and philosophical works from different traditions including the Church fathers and the medieval theologians.

Consequently, Arminius interacted with numerous and diverse theological and philosophical voices to construct his own theological work. In order to understand Arminius's theology, it seems critical to review some of his most probable theological influences. I propose that, first, it is important to summarize briefly central theological

respect to all known sources of information and the rules of rational discourse, followed but a full response to all objections," Muller, After Calvin, 27. For more information regading reformed scholasticism see, Justo L. González, The History of Theological Education (Nashville, TN: Abingdon Press, 2015), in eBook Collection (EBSCOhost), EBSCOhost (accessed March 15, 2017).

${ }^{40}$ Muller, After Calvin, 28.

${ }^{41}$ Asselt, Reformed Scholasticism, 104; Muller, PRRD, 1:31.

${ }^{42}$ Muller, "Problem of Protestant Scholastism - A Review and Definition," in Reformation and Scholasticism: An Ecumenical Enterprise, ed. Willem J. Van Asselt and Eef Dekker (Grand Rapids, MI: Baker, 2001), 45-64; Muller, "Reformation, Orthodoxy, 'Christian Aristotelianism," Nederlands Archief voor Kerkgeschiedenis 81 (2001): 306325. 
ideas within the Reformed tradition. And second, it is also essential to see Arminius in the wider spectrum of theological reactions against Calvin's idea of predestination.

\section{Central Theological Concepts}

In order to understand Arminius's theological work, it seems important to consider the critical doctrinal issues that theologians were facing at the end of the sixteenth century. A question is how Arminius related to and worked with those important theological issues of his time? There is a risk here of oversimplifying the theological issues that abounded during Arminius's life. However, I will restrict myself to the consideration of three main topics, topics I choose for their importance for Arminius's theology: The relationship between free will and grace, predestination and election, and the ordo salutis in God's program of salvation.

One main theological topic was the relationship between human free will and God's grace. ${ }^{43}$ Since the early days of the Reformation, this topic was a contentious problem for all the Reformers as well as Catholic theologians. Erasmus of Rotterdam in his treatise De libero arbitrio diatribe sive collatio (On Free Will) and Martin Luther in his reply De servo arbitrio (On the Bondage of the Will) stridently disputed the role of human will and God's sovereign grace in salvation. Similarly, John Calvin, the Anabaptists, and most of the reformers dedicated extensive analysis to the issue.$^{44} \mathrm{By}$ the

${ }^{43}$ Van Asselt, Reformed Scholasticism, 105-107.

${ }^{44}$ Consider John Calvin, The Bondage and Liberation of the Will: A Defense of the Orthodox Doctrine of Human Choice Against Pighius, ed. A. N. S. Lane; trans. G. I. Davies, Texts \& Studies in Reformation \& Post-Reformation Thought (Grand Rapids, MI: Baker, 1996); Balthasar Hubmaier, "On Free Will," in Spiritual and Anabaptist 
time of Arminius, the subject was still an ongoing question. Arminius himself dedicated considerable effort to the issue that he regarded as central for human salvation and God's character. William van Asselt explains that the dispute that was already present within the Catholic church came to the Reformed camp, that those who followed Reformed orthodoxy sided with Aquinas and the Arminians and Lutherans followed Suarez and Molina. $^{45}$

Another key discussion within reformed tradition was on the issue of predestination. The concept of double predestination was not only a construction of Calvin, but also of Huldrych Zwingli, Martin Bucer, Heinrich Bullinger, and Theodore Beza. ${ }^{46}$ One would expect to find the stronger controversies on predestination within this particular branch of the Reformation. Divines at the time usually wrote small treatises regarding the different views on the topic, ending with a defense of their own opinions. ${ }^{47}$

Writers, vol. 25, Documents Illustrative of the Radical Reformation, ed. George Huntston Williams, Library of Christian Classics (Philadelphia, PA: Westminster, 1962), 114-135.

${ }^{45}$ Van Asselt, Reformed Scholasticism, 107.

${ }^{46}$ For detailed analysis of the doctrine of predestination in the theology of the aforementioned reformers, see R. Olson, Story of Christian Theology, 401- 404; 410413; W. P. Stephens, The Theology of Huldrych Zwingli (New York: Oxford Univesity, 1986), 39-44, 97-107; W. P. Stephens, The Holy Spirit in the Theology of Martin Bucer (New York: Cambridge University Press, 1970), 23-41; Timothy George, Theology of the Reformers (Nashville, TN: Broadman \& Holman, 1988), 122-126; Richard A. Muller, Christ and the Decrees: Christology and Predestination in Reformed Theology from Calvin to Perkins (Durham, NC: The Labyrinth, 1986), 79-96; Richard A. Muller, "John Calvin and later Calvinism: The Identity of the Reformed Tradition," in The Cambridge Companion to Reformed Theology, ed. David Bagchi and David C. Steinmetz (Cambridge, UK: Cambridge University Press, 2004), 144.

${ }^{47}$ Keith D. Stanglin, ““Arminius Avant La Lettre': Peter Baro, Jacob Arminius, and the Bond of Predestinarian Polemic," WTJ 67 (2005): 58. For a brief summary on 
Not only did Arminius argue throughout his writings against the predestinarian conceptualization of the forerunners of Reformed theology, but in his Declaration of Sentiments he followed a similar structure to that of his contemporaries.

These soteriological discussions on God's grace and human free will and the concept of predestination resulted in general analysis and constructions of the divine ordo salutis. During the post-Reformation period, Protestant and Catholic theologians alike described the process of salvation in "highly sophisticated" logical or temporal sequences. ${ }^{48}$ The ordo salutis described the essential unity and interrelations of the multidimensional divine actions in favor of human redemption, and highlighted aspects like calling, illumination, faith, election, justification, and glorification. In contrast to John Fesko, who argues that a Reformed ordo salutis results from a biblical reflection on Romans 8:29-30, I think that while in some instances the ordo salutis naturally developed from biblical reflection, in others it responded to rational and doctrinaire impositions upon the Scriptures. ${ }^{49}$ Like his contemporaries, then, Arminius developed a clear ordo salutis. Obviously, the sequences of the Holy Spirit's movements in

Arminius's theological context see, J. Matthew Pinson, "Will the Real Arminius Please Stand up? A Study of the Theology of Jacobus Arminius in Light of His Interpreters," Integrity 2 (2003): 121-139.

${ }^{48}$ Jaroslav Pelikan, The Christian Tradition: A History of the Development of Doctrine, vol. 3, The Growth of Medieval Theology, 600-1300 (Chicago, IL: The University of Chicago Press, 1978), 108; Veli-Matti Kärkkäinen, "Ordo Salutis," in Global Dictionary of Theology: A Resource of the Worldwide Church. ed. William A. Dyrness and Veli-Matti Kärkkäinen (Downers Grove, IL: InterVarsity, 2008), 622.

${ }^{49}$ John V. Fesko, Beyond Calvin: Union with Christ and Justification in Early Modern Reformed Theology, 1517-1700, Reformed Historical Theology, ed. Herman J. Selderhuis, vol. 20 (Göttingen, Germany: Vandenhoeck \& Ruprecht, 2012), 261-262. 
Arminius's ordo salutis appear differently from the understanding of his Calvinist colleagues. So it is critical to keep in mind these theological concepts while working to understand Arminius's theology and the role of prevenient grace.

\section{The Wider Context of Arminius's Theological World}

Arminius belongs to a wider theological world of anti-predestinarian thinkers in the late sixteenth century. It is impossible to understand Arminius without a knowledge of this reality. Catholic and Anabaptist theologians consistently rejected the doctrine of predestination in the way that the magisterial reformers understood it. However, here I focus on the reactions within the Reformed tradition. Not all Reformation theologians accepted the Reformed and early Lutheran understanding of human free will and God's grace in the context of predestination. Since Calvin's day theological voices like Albertus Pighius, Jerome Bolsec, and Sebastian Castellio have pointed to the awful theological implications of the doctrine of predestination, such as making God the author of evil and thus destroying the goodness of God. ${ }^{50}$

It is interesting that here we find a probable connection between the ideas of Calvin's opponents and Arminius. It is more probable than not that Arminius was familiar, at least historically, with the ideas of Pighius, Bolsec, and Castellio. However, it is in the writings of Coornhert that we find the ideas of Castellio disseminated in the Netherlands. Coornhert is the same person to whom the consistory in Amsterdam asked

${ }^{50}$ Mirjam G. K. van Veen, "Calvin and His Opponents," in The Calvin Handbook, ed. Herman J. Selderhuis, trans. Henry J. Baron, Judith J. Guder, Randi H. Lundell, and Gerrit W. Sheeres (Grand Rapids, MI: Eerdmans, 2009), 160-161. 
Arminius to respond. Finding support in Castellio, Coornhert opposed Calvin's doctrine of predestination affirming human freedom of choice and human capacity to receive God's grace. ${ }^{51}$ It is a historical fact that Castellio and Coornhert incited a theological revolution over freedom of will in the Netherlands. Arminius himself reported that the opponents to Calvin's view around 1590 were numerous. However, at the time he did not count himself among them. ${ }^{52}$

Reactions against the doctrine of predestination were not limited to the Netherlands. In England, Puritan theologians advanced a strict view on predestination, even calling others to promote it systematically in preaching, teaching, and publishing. ${ }^{53}$ However, a group of anti-predestination theologians called "freewillers" by their contemporaries opposed the radical conclusions of their Calvinist contemporaries. ${ }^{54}$ As

${ }^{51}$ Mirjam G. K. van Veen and Jesse Spohnholz, "Calvinist vs. Libertines: A New Look at Religious Exile and the Origins of 'Dutch' Tolerance," in Calvinism and the Making of the European Mind, ed. Gijsbert van den Brink and Harro M. Höpfl (Leiden, the Netherlands: Brill, 2014), 88.

52 Bangs, Arminius, 139-140.

${ }^{53}$ Dewey D. Wallace, Jr., Puritans and Predestination: Grace in English Protestant Theology, 1525-1695 (Eugene, OR: Wipf \& Stock, 1982), 41-44.

${ }^{54}$ Today, somehow anachronistically, these are known as Arminians avant la lettre and their movement as 'English Arminianism.' English controversies against Dutch Arminianism were not widespread in England until 1610 after the published work of Arminius was available. See Wallace, Puritans and Predestination, 79-111; Nicholas Tyacke, Anti-Calvinists: The Rise of English Arminianism c. 1590-1640 (Oxford: Clarendon, 1987), 38. See also the interesting description of the early development of free will thinkers in England, O. T. Hargrave, "The Freewillers in the English Reformation," Church History, vol. 37, no. 3 (1968): 271-280; Thomas Freeman, "Dissenters from a Dissenting Church: The Challenge of the Freewillers, 1550-1558," in The Beginning of English Protestantism, ed. Peter Marshall and Alec Ryrie (Cambridge, UK: Cambridge University Press, 2002), 129-156. 
early as 1569, Anthony (Antonio del) Corro, an Spanish reformer and former Calvinist minister, at Oxford argued that election and reprobation rest on the presence of "faith or its lack" in the life of believers. ${ }^{55}$ Likewise, during the early 1590s William Barret, Peter Baro, and John Overall at Cambridge favored an unlimited view of atonement, understood faith as the ground of election and perseverance of the saints as conditional upon a continued life of faith. ${ }^{56}$ These are obviously similar views to those present later in Arminius's writings. Interestingly, Arminian scholars do not find an influence of these

${ }^{55}$ Tyacke, Anti-Calvinists, 58. Antonio del Corro (1527-1591) was a Spanish Hieronymite friar in the monastery of San Isidro, Spain. The monastery of San Isidro was a center of Protestantism and reform in Spain where important figures of the Spanish Reformation, like Cassiodoro de Reina and Cipriano de Valera, promoted evangelical and protestant ideas and harshly criticized the spiritual condition of the Church. Eventually, Corro became a leading figure of Reformed Protestantism. However, Paul J. Hauben prefers to catalogue him as an "Evangelical Calvinist." This is because he consistently refused to condemn the Anabaptist and other radical movements of the Reformation. He studied under Calvin and Beza in Geneva, and like Arminius after him, he received a recommendation from Beza, and even Calvin, for the ministry. In his ministerial work, he founded and pastored churches in France, Netherlands, and England. He dedicated his pastoral ministry to evangelize with the Protestant message the Spanish refugees and emigrants. During his ministry in France, he maintained a cordial relationship with Calvin, who defended him from unfounded accusations of Servetianism. However, this changed after Beza assumed the leading role in the Reformed tradition. It seems that Beza was more open to listen and accept the charges of unorthodoxy against Corro. The facts, nevertheless, seem to indicate that after his settlement in England, he started, slowly but decisively, to distance himself from the Calvinist view of predestination. Moving closer to the Anglicans in England, Corro wrote his Dialogus Theologicus balancing the Protestant views on grace, election, and the human role in salvation. The only complete analysis of Corro's life and ministry is the unpublished $\mathrm{PhD}$. dissertation of W. McFadden, "The Life and Works of Antonio del Corro, 1527-1591" (PhD diss., Queen's University Belfast, 1953). I have based this brief analysis on Paul L. Hauben, Three Spanish Heretics and the Reformation (Genève, Switzerland: Librairie Droz, 1967), 3-81.

${ }^{56}$ Ibid., 30, 35, 37. Peter Baro, a French refugee in England, was undoubtedly influence by Corro, see Hauben, Spanish Heretics, 68. 
English divines upon Arminius's theology, or vice versa. Stanglin says that "English Arminianism" developed independent of the Continent. ${ }^{57}$ Similarly, Bangs states that Baro most probably never knew the works of Arminius. ${ }^{58}$

However, with appropriate caution I suggest that there are some interesting and possible connections between Arminius and these Spanish, French, and English free will thinkers. They were all familiar with the work of the prestigious Danish Lutheran theologian Neils Hemmingsen (Nicholas Hemmingius, 1513-1600). Corro appealed to Hemmingsen as his authority, Baro submitted to him his opinions on predestination for approval and publication, and Arminius referred to his writings as support in his Declaration of Sentiments. ${ }^{59}$ One important historical question could be: To what extent did Hemmingsen's writings and theology nurture and influence their anti-predestinarian theology? Regrettably, no studies have investigated the nature of the influence of Hemmingsen on Corro, Baro, and Arminius. It would also be critical to explore the similarities and differences between Hemmingsen, Corro, and Baro's theology and that of Arminius.

${ }^{57}$ Stanglin says that "although there is evidence for indirect connections between English anti-Calvinism ... and Arminius ... English-Arminianism began as an indigenous movement independent of Arminius himself," in "Arminianism," in Global Dictionary of Theology, ed. William A. Dyrness and Veli-Matti Kärkkäinen (Downers Grove, IL: IVP Academic, 2008), 62; see also Stanglin, "Arminius Avant la Lettre," 5152.

${ }^{58}$ Bangs, Arminius, 209.

${ }^{59}$ Tyacke, Anti-Calvinists, 59; Bangs, Arminius, 207; Peter Baro, "Letter to Mr. Nicholas Hemmingius," in Works, 1:91; Peter Baro, "Three Opinions Concerning Predestination," in Works, 1:92-100; Decl. Sent., in Works, 1:642-643. 
One thing is possible to conclude: that Arminius's wider theological context was involved in a widespread reaction against the Calvinist doctrine of predestination. Those opposed to the doctrine believed that the reading of the Confessions, Catechism, and other church documents through a Calvinist worldview necessarily distorted the biblical teachings about God's love and goodness and represented God as the creator of evil and as a moral monster.

\section{Jacobus Arminius: The Person}

Having considered the social, religious, and theological world of Arminius, it is now time to pay attention to the person in that context. In this section, I discuss Arminius's early life as well as his experiences as a student, pastor, and theologian.

\section{Early Years: Family and Patrons}

Although the precise date of Jacobus Arminius's birthday is uncertain, he most probably was born around 1559 in a small Dutch town named Oudewater. ${ }^{60}$ Arminius never knew his father and his entire family was assassinated by Spanish troops in the massacre of Oudewater in August 7, $1575 .{ }^{61}$ Bertius reports that in the Spanish attack of

${ }^{60}$ The biographical information in this chapter predominantly relies on the classical accounts of Arminius's life by Bertius, Brant, and Bangs with a few references to other shorter introductions to Arminius. Arminius's birth name was Jacob Harmensz or Harmenszoon, later Latinized to Jacobus Arminius. The traditional date of Arminius's birth - October 10,1560 — seems to be historically inaccurate because Bangs has successfully demonstrated that his father died "not later than 1558," which would mean that Arminius was born late in 1558 or early in 1559. Bangs, Arminius, 25. See also Stanglin and McCall, Theologian of Grace, 25-26; Gunter, Arminius and His Declaration of Sentiments, 12.

${ }^{61}$ Bangs, Arminius, 37-44; Stanglin and McCall, Theologian of Grace, 27; 
the town "scarcely a single inhabitant had escaped the general carnage, and that his [Arminius] mother, sister, brother, and other relations, had unfortunately perished." 62 The recollection of such a tragedy left a great and sorrowful impression on Arminius's mind long after the event. He always referred to the character of the Spaniards as a people "who cannot exist without having an enemy" $" 63$ and recalled the tragedy of his small town in elegiac and poetic verse. ${ }^{64} \mathrm{I}$ have previously discussed the Oudewater experience.

Arminius probably left his home as soon as he was "capable of receiving the elements of learning" ${ }^{\prime 65}$ to study in Utrecht ${ }^{66}$ under the tutelage and with the financial

Gunter, Arminius and His Declaration of Sentiments, 13-14.

${ }^{62}$ Peter Bertius, 'An Oration on the Life and Death of that Reverend and Very Famous Man James Arminius, D. D.', in Works, 1:19.

${ }^{63}$ Orat. 5., in Works, 1:460.

64 “Ah! fuit in Batavis urbecula finibus olim, quae nunc Hispani strata furore jacet,

Huic Undae Veteres posuerunt nomina prima;

Haec mihi nascenti patria terra fuit." See Oration, in Works, 1:19.

${ }^{65}$ Oration, in Works, 1:17. See also Brant, The Life of James Arminius, 14.

${ }^{66}$ In spite of the lack of direct evidence, Bangs advances the hypothesis that Arminius's early years of preparation happened at St. Jerome School. See Bangs, Arminius, 34-36. The school was founded as a center of humanistic studies under the influence of the Brethren of the Common Life, a Roman Catholic pietistic or mystic community founded in Netherlands in the fourteenth century by Gerard Groote. It is interesting to note that Luther and other reformers received their early education at other schools of the very same order. Perhaps for this reason and notwithstanding that the Brethren never abandoned the Catholic doctrines and teachings, the order has been regarded as a critical precursor of Reformed ideas. See Earle E. Cairns, Christianity Through the Centuries: A History of the Christian Church, 3rd ed. (Grand Rapids, MI: 
support of Theodore Aemelius, a former Catholic priest who had become a Protestant minister. Aemelius discovered in Arminius not only intellectual aptitudes but most importantly a pious disposition. Consequently, he encouraged his young protégé to pursue an education and to dedicate his life, talents, and conscience to God's service in hopes of a more glorious and eternal mode of existence ${ }^{67}$ The admonitions of his protector and Arminius's assiduous dedication in studying the Holy Scriptures bore fruit in a pious life with the mission of honoring God. ${ }^{68}$ Unfortunately, Arminius lost his human supporter and counselor when Aemelius suddenly died of "an unexpected calamity. ${ }^{" 69}$ Abruptly, Arminius was left to face the harshness of life without a family, sponsor, or economic support. But despite all these calamities and trials, Arminius survived. Brandt, a remonstrant theologian and historian, described in emotional terms the divine intervention in favor of Arminius; "the great and ever blessed God, the neverfailing father of the orphan, did not leave the youth, now in his 15 th year, to pine in the hopeless grief into which he had been plunged by the loss of so beloved a benefactor.",70

Zondervan, 1996), 243-244; Heiko A. Oberman, Luther: Man Between God and the Devil (New Haven, CT: Yale, 1989), 96-97; Gotthard V. Lechler, John Wiclif and His English Precursors (London: Kegan, Paul, Trench, 1881), 8; Carl Ullmann, Reformers Before the Reformation, Principally in Germany and The Netherlands, trans. Robert Menzies, vol. 2 (Edinburgh: T \& T Clark, 1850), 10.

${ }^{67}$ Oration, in Works, 1:18. See also Brant, The Life of James Arminius, 14.

${ }^{68}$ Oration, in Works, 1:18.

${ }^{69}$ Bangs, Arminius, 34.

${ }^{70}$ Brant, The Life of James Arminius, 14-15. 
God favored Arminius one more time with a new patron. Rudolph Snellius (1547-1613), a famous mathematician, linguist, and a fellow countryman of Arminius, became Arminius's new benefactor and continued to provide him with excellent education at the University of Marburg and later at the new University of Leiden (from 1576 to 1582$).{ }^{71}$ He most probably exercised his influence to find support for Arminius

${ }^{71}$ Brant, The Life of Arminius, 18. The University of Marburg was the second center of studies for Arminius. The University was the first Protestant center of study "founded in 1527 by Philip of Hesse, see Bangs, Arminius, 38. Philipp Melanchthon was instrumental in founding the university, and exercised great influence on its curriculum and educational methods. See Werner Korthaase, "Phillip Melanchthon, Praeceptor Germaniae, and His Influence on Theories of Education in Bohemia and Moravia," in Luther and Melanchthon in the Educational Thought in Central and Eastern Europe, ed. Reinhard Golz and Wolfgang Mayrhofer (Münster, Germany: Lit, 1998), 77-79; Ulrich G. Leinsle, Introduction to Scholastic Theology, trans. Michael J. Miller (Washington D.C.: Catholic University of America Press, 2010), 246. Nonetheless, little is known about Arminius's training at Marburg. However, it is interesting to note that Arminius's time in Marburg coincided with the mathematician Lazarus Schöner (1543-1607), professor and promoter of Ramism in the University from 1575-1577; indeed the time when Schöner was at the University is called the "golden age of Ramism in Marburg," see Gábor Kecskeméti, "The Reception of Ramist Rhetoric in Hungary and Transylvania: Possibilities and Achievements" in Ramus, Pedagogy and the Liberal Arts: Ramism in Britain and the Wider World, ed. Steven J. Reid and Emma Annette Wilson (Farnham, England; Burlington, VT: Ashgate, 2011), 210.

It is well known that Ramus's logic exercised a great influence on Arminius's thinking. Another possible influence that Arminius received at Marburg was from Melanchthon's theology. However Bangs concedes "[that] Melanchthonian influence extended down to 1575 to be felt by Arminius cannot be determined." See Arminius, 38. Nevertheless, years later, Arminius mentioned Melanchthon as one of the great Reformers that was in agreement with his position on predestination. See Decl. Sent., in Works, 1:642. Probably Arminius was not influenced theologically by Melanchthon during his time in Marburg, but he certainly had several critical works of Melanchthon in his own library. See Stanglin, Arminius on Assurance of Salvation, 84n47.

As soon as Arminius learned about the new university in Leiden, founded by William I, the Prince of Orange, on February 6, 1576, he decided to return to his homeland to study there. Bangs says that he "enrolled on October 23, 1576, as a student of liberal arts" becoming only the twelfth student at Leiden. See Oration, in Works, 1:20 
in his studies at Geneva and Basel. Snellius introduced Arminius to the philosophical thinking of Peter Ramus as well as to the study of mathematics and astronomy. ${ }^{72}$

Once he had completed his studies at Leiden, Arminius obtained the support of the powerful senators and pastors of Amsterdam and the financial patronage of the merchants' guild. With the financial support of the people of Amsterdam, Arminius began his studies at the University of Geneva under the well-known theologian and disciple of Calvin, Theodore Beza. ${ }^{73}$ Thus, Arminius's education took place at several respected European institutions of the sixteenth century. By all accounts he was very successful in his studies and gained the recognition of his teachers and fellow students. The long years of studies under well-known professors trained Arminius ably in topics ranging from "dialectic, rhetoric, mathematics, and physics" ${ }^{\text {"74 }}$ to classical languages, biblical studies, exegesis, theology, philosophy, and the church fathers. ${ }^{75} \mathrm{He}$ distinguished himself by his keen power of logical analysis and clarity of biblical exposition. As a result of both his diligence in study and natural intellectual power, Arminius concluded his studies fully prepared for a life of pastoral ministry and teaching.

and Bangs, Arminius, 47.

${ }^{72}$ Brant, The Life of Arminius, 18; Bangs, Arminius, 38.

${ }^{73}$ Brant, The Life of Arminius, 19-20; Bangs, Arminius, 64. For a treatment of Arminius as a student, see Gunter, Arminius and His Declaration, 21-42.

${ }^{74}$ Bangs, Arminius, 35.

${ }^{75}$ Gerald McCulloh, Man's Faith and Freedom: The Theological Influence of Jacobus Arminius (Eugene, OR: Wipf and Stock Publishers, 2006), 12. 
Bangs came to speculate that Arminius's association with the merchants' guild resulted not only in financial support for his studies, but later also provided him with a good marriage to Lijsbet, the daughter of the influential merchandizer Laurens Jacobsz Real. ${ }^{76}$ They eventually had a family of twelve children, of whom only nine reached adulthood. $^{77}$

One could ask, how did Arminius obtain the patronage of such powerful and wealthy people? A probable answer is that Arminius was born into a middle-class family with connections within the social strata of the merchants. In other words, Arminius was not a member of a noble family, but neither was he one of the poor peasants of the land. By the end of the sixteenth century in the Netherlands, merchants had positioned themselves as a dominant commercial power, a significant political influence, and a prominent economic force. They had the financial means to help their protégés to navigate without financial need education or any other enterprise. ${ }^{78}$ Certainly, Arminius's loss early in life had the potential to jeopardize his future and education; however, patrons rescued him by contributing to the necessities of life and school. ${ }^{79}$ Throughout his

${ }^{76}$ Bangs, Arminius, 66. Arminius married Lijsbet Jacobsz on September 6, 1600 in the Old Church of Amsterdam. See note on Oration, in Works, 1:31.

${ }^{77}$ Bangs, Arminius, 250.

${ }^{78}$ Dutch merchants dominated the European trade from the end of the sixteenth century to the end of the seventeenth, Arminius's lifetime. See Jonathan I. Israel, Dutch Primacy in World Trade 1585-1740 (New York: Oxford, 2002), 12-79.

${ }^{79}$ Brant states that Arminius's mother enjoyed a network of friends that helped her to raise her children to the point that they did not suffer shortages or needs. See Brant, The Life of Arminius, 13. 
life until he was able to take care of himself, his patrons supplied him with a wide array of social, financial, and political resources. ${ }^{80}$

\section{Student Life: Theological Influences}

Carl Bangs has traced the theological influences on Arminius's religious studies. Because little can be said with certainty about Arminius's studies at the St. Jerome School and in Marburg, I focus here on his years at Leiden, Geneva, and Basel. During the Dirck Volckertz Coornhert crisis, Arminius was a student at Leiden, where a mix of moderate Calvinist theologians like Johann Kolmann and Guilhelmus Feugueres and strict Calvinist like Lambertus Danaeus were teaching and ministering. ${ }^{81}$ Feugueres did not support the Reformed overemphasis on the doctrine of predestination and God's sovereignty, at least not in Beza's terms. ${ }^{82}$ In addition, historical evidence seems to suggest that Beza's supralapsarian view of salvation did not find great support either in Holland or in other Low Countries. ${ }^{83}$ For instance, important Dutch ministers like Albert Hardenberg, Clemente Martenson, and John Isbrandtson publicly resisted the introduction of the theology of Geneva in Holland. ${ }^{84}$ Bangs says that "from the very

${ }^{80}$ Bangs, Arminius, 83.

${ }^{81}$ Bangs, Arminius, 50-52; Carl Bangs, "Arminius and the Reformation" Church History 30, no. 2 (1961): 161; Justo González, A History of Christian Thought, vol. 3, From the Protestant Reformation to the Twentieth Century, rev. ed. (Nashville, TN: Abigdon Press, 1987), 280

${ }^{82}$ Bangs, Arminius, 50-52.

${ }^{83}$ Bangs, "Arminius and the Reformation," 155-170.

${ }^{84}$ Ibid., 159-160. 
beginning of the introduction of Reformed religion in the Low Countries ... the milder views of the Swiss cantons were in evidence.." ${ }^{85}$ This does not necessarily mean that they were radically anti-Calvinist. Arminius was evidently in contact with their ideas and their kind of moderate Calvinism and was most probably influenced by them while he was maturing his own theological thinking.

In Geneva, Theodore of Beza surely exercised theological influence on Arminius. ${ }^{86}$ Beza was very directive and intentional in selecting both the professors and the theological and biblical contents of the curricula at the Academy. ${ }^{87}$ For instance, by the time Arminius arrived at the Academy, many of Beza's doctrinal and polemical works like Tabula praedestinationis of 1555 and Tractiones theologicae of 1570-1582 had already been published and were critical sources of reading and study by all students under his supervision. Indeed, in these writings he systematically defended his view of unconditional and absolute predestination and that view later "became the normative view for late-sixteenth-century Calvinists." ${ }^{88}$ For it to attain a normative role in the

${ }^{85}$ Bangs, “Arminius and the Reformation," 158.

${ }^{86}$ For a list of the many prominent theologians influenced by Beza through his teachings at Geneva, see Jeffrey Mallinson, Faith, Reason, and Revelation in Theodore Beza 1519-1605, Oxford Theological Monographs (Oxford, UK: Oxford University Press, 2003), 32-33.

${ }^{87}$ Shawn D. Wright, Our Sovereign Refuge: The Pastoral Theology of Theodore Beza, Studies in Christian History and Thought (Cumbria, UK: Pasternoster, 2004), 1820.

${ }^{88}$ Peter White, Predestination, Policy, and Polemic: Conflict and Consensus in the English Church from the Reformation to the Civil War (New York: Cambridge University Press, 1992), 13. 
Reformed tradition would have been unlikely if it were not for the great influence he had on his students who later expanded his ideas. Arminius's reaction and response to Beza's doctrine of predestination demonstrates his profound familiarity with the ideas of his former teacher.

\section{Theological Writings}

Scholars, however, have given more detailed attention to the influence of the theologians that Arminius actually had at hand in his library and those whom he specifically quoted in his writings. While Muller seems to me to overemphasize the influence on Arminius of Catholic scholars like Aquinas and Molina, ${ }^{89}$ Stanglin and McCall point to a wider spectrum in Arminius's theological influences. ${ }^{90}$ The theological works of church fathers like Augustine and Jerome, medieval scholars like Peter Lombard and Aquinas, and predecessor Reformers like Melanchthon and Calvin were available to Arminius while he was preparing his lectures and writings. I found that Arminius used their ideas and in some cases their conclusions, but that he did so only after establishing considerable support for those ideas and conclusions in Scripture. For instance, Arminius's view on election as the result of God's foreknowledge of human acceptance of grace is akin to Augustine's early view on the topic. At the same time,

${ }^{89}$ Muller, God, Creation, and Providence, 31-39; Muller, "Arminius and the Scholastic Tradition," 264-266; Muller, After Calvin, 73; James E. Bradley and Richard A. Muller, Church History: An Introduction to Research, Reference Works, and Methods (Grand Rapids, MI: Eermans, 1995), 36-37, 50; Muller, "Arminius and Arminianism" in DHT, 34.

${ }^{90}$ Stanglin and McCall, Theologian of Grace, 19, 39-46. 
Arminius strongly rebuked his sources for affirming concepts "which are not found in the Scriptures, and which demand prolix explanation, lest they be drawn into an occasion of blasphemy and heresy."${ }^{, 91}$

Yet, what does the eclecticism of Arminius's sources indicate? Was Arminius a Molinist, scholastic, humanist, Thomist, Melanchthonian, or Calvinist? Yes and no. It seems to me that Arminius as a great theologian was constructing his system of theology solidly on his reading of the Bible and at the same time drawing support from different theological sources. In this he was not radically different from his contemporaries and his teachers. For instance, his interest in Aquinas seems to be similar to the interest of his former teacher Beza. Instead of looking for Thomistic conclusions, their interest is in Aquinas's method and structures for the formulation of theology. ${ }^{92}$ For that reason, reducing Arminius to the conclusions and even methodologies of a specific tradition or theologian seems to me to be a misrepresentation of the true nature of his theology. To my mind, he was more a theological erudite than a humanist, more of a Biblicist than a Molinist. ${ }^{93}$

${ }^{91}$ Arminius openly directed this warning against Jerome and Augustine. He also called into question some of the assertions of Calvin and Beza because they "are not agreeable to the truth." See Perkins Exam., in Works 3:367, 369.

${ }^{92}$ Mallinson, Faith, Reason, and Revelation, 46-47.

${ }^{93}$ A good piece of evidence that Arminius does not easily fit in a specific category is the common disagreement among Arminius scholars regarding labeling him with specific theological schools of thought. For instance, Arminius's identification as a Molinist has recently been contested by Kirk R. MacGregor, Luis de Molina: The Life and Theology of the Founder of Middle Knowledge (Grand Rapids, MI: Zondervan, 2015), 18-24. MacGregor contends that Arminius and Molina radically disagree on the nature of God's middle knowledge and the interpretation of Romans 9. William G. Witt 


\section{Professional Life: Pastor and Professor}

Arminius dedicated most of his twenty-one years of professional life to pastoral ministry. This means that before all else he was a pastor. He began to preach at the Church of Amsterdam on February 7, 1588 and finished his pastorate on April 15, 1603. ${ }^{94}$ Obviously, common pastoral duties like presiding at baptisms, marriages, funerals, and making pastoral visits remained day-to-day activities of his life. But he was also frequently commissioned to take on special duties like representing the Church at national events, exercising leadership in national synods, improving the Church order, calling new pastors, and overseeing financial and administrative matters. ${ }^{95}$ This demonstrates that Arminius was an able pastor, and during years of faithful clerical work, gained the admiration and support of his congregation and leaders. However, his role as

came to the same conclusion as MacGregor before him in his dissertation "Creation, Redemption and Grace in the Theology of Jacob Arminius," 357, 361, 366. A similar conclusion is found in F. Stuart Clarke, The Ground of Election: Jacobus Arminius's Doctrine of the Work and Person of Christ (Colorado Springs, CO: Paternoster, 2006), 123. On the other hand, Eef Dekker passionately defends the notion that Arminius was actually a Molinist. See Dekker, "Was Arminius a Molinist," 337-352. Before Dekker, Muller came to the same conclusion in God, Creation, and Providence, 155-161; see also Muller, "Grace, Election, and Contingent Choice: Arminius's Gambit and the Reformed Response" in The Grace of God, the Bondage of Will, 2:264-266. Muller contends that middle knowledge is incompatible with the Reformed view of God's knowledge; it was "not a middle ground. It was the Arminian, just as it was the Jesuit view," Ibid., 266. Finally William den Boer is of the same opinion, see God's Twofold Love, 143-148. I will give consideration to Arminius's concept of God's knowledge in relation to prevenient grace in chapter 5 .

${ }^{94}$ Bangs, Arminius, 113, 115, 237. Arminius first was a "minister on trial," later he was officially ordained, and on August 27, 1588, he was accepted as a full pastor.

${ }^{95}$ Bangs, Arminius, 155. 
preacher and apologist, as well as a compassionate pastoral caregiver particularly marked his ministry.

He was a gifted and popular preacher. Preaching was so central to his ministry that even when he became a professor at Leiden, Arminius continued to preach in Leiden churches. ${ }^{96}$ In his sermons, he gave distinctive attention and preeminence to the exposition of Scripture over dogmatic teachings. He felt called to "publish, preach, interpret and expound" the Word of God as well as to carefully "distinguish and discriminate it from [other] words or writings" even those of "the Church Universal." ${ }^{.97}$ If Arminius's extant writings are any indication, the preaching of God's grace, mercy, and love for sinners as presented in the Gospel likely were central to most of his sermons and writing. Yet he also attended to the law as a way to stir up the consciences of his listeners regarding their sinful condition and their need to repent and submit to God's grace. From the beginning of his ministry, says Bangs, in his sermons Arminius was "dealing with grace and predestination" as well as divine election and human responsibility. ${ }^{98}$

Arminius was genuinely and personally involved in the pastoral care he offered. He frequently visited his members to discipline, to encourage faith, and to show compassion for the sick. Records of his pastoral work show that, for example, he

${ }^{96}$ Mark A. Ellis, Simon Episcopius's Doctrine of Original Sin (New York: Peter Lang, 2006), 41.

${ }^{97}$ Pub. Disp. I, in Works, 2:81.

${ }^{98}$ No written sermons of Arminius remain; however, we know that he preached several sermons on Romans and Malachi. See Bangs, Arminius, 128. 
ministered to a woman who was disavowing her Reformed faith, corrected an adulterer, and worked for the reconciliation of two belligerent believers. ${ }^{99}$

As a man of sorrow, Arminius's previous experience of loss enabled him to minister with great compassion to those who were suffering. He himself had experienced the agonizing loss of his whole family and later carried to their graves in his own arms the inanimate bodies of three of his children. ${ }^{100}$ During an outbreak of bubonic plague in Amsterdam, Arminius's pastoral compassion was exemplary; he took care for the sick, most of whom were from the unprivileged and poor population, and imparted assurances of salvation to those who were confronting imminent death. ${ }^{101}$ As in his preaching, Arminius believed that in pastoral care the crucial thing was to call humans to "a decisive choice for or against the offered salvation" in the Gospel. ${ }^{102}$

Confronting heresy during his pastoral career frequently occupied Arminius's attention. Sometimes he was asked to do the job; other times he pushed himself to take it on. He was an astute and skillful apologist competent in using Scripture and the extensive tradition of Church doctrine, practice, and theology. For instance, he several times remonstrated with Goosen Michelsz Volgelsangh — though to no avail— to neutralize biblically and theologically his anti-Trinitarian and anthropomorphist views of God.

${ }^{99}$ Bangs, Arminius, 153-155.

${ }^{100}$ Ibid., 152.

${ }^{101}$ Ibid., 174.

${ }^{102}$ Herman Selderhuis, ed., Handbook of the Dutch Church (Göttingen, Germany: Vandenhoeck \& Ruprecht, 2015), 302. 
Ironically, it was in relation to his responsibilities to respond to some dissenting teachings that he called his own orthodox beliefs into question. According to Bertius, when Arminius was appointed to respond to the anti-Supralapsarian teaching of the ministers of Delf, Aren Cornelisz and Reynier Donteklok, after careful biblical consideration Arminius changed his views on divine election and the role of human will. ${ }^{103}$ Consequently, he came to agree with his opponents concluding, according to Bertius, that "the decree of God, in respect to Predestination, was, out of men already created and fallen, to elect those who would answer, by the true obedience of faith, to the call of God." ${ }^{\prime 04}$ This opinion Arminius avidly sustained and defended throughout the rest of his ministry.

Recent scholarship has disputed Bertius's account, affirming instead that Arminius was already a free will and anti-predestinarian thinker when he was appointed as a pastor in Amsterdam. A brief consideration should be given to these contrasting claims in this narrative of Arminius's life. Bangs speculates that Arminius was called to confront these ministers because the consistory and the pastors already had some suspicions of Arminius's orthodoxy on the topic of predestination. If that was the case, this task would have given him the opportunity to reveal his real sentiments or understanding on this issue. He concludes that "there is no clear evidence that Arminius

103 Oration, in Works, 1:29-30. James Nichols, in Appendix E and F of his translation of Arminius's work, follows the report of Bertius, stating that "Arminius parted from the supralapsarian doctrines, which he had imbibed in his very boyhood, and which were afterwards confirmed and fixed in him by the authority and persuasive eloquence of the venerable Beza," in Works, 1:65.

${ }^{104}$ Oration, in Works, 1:30. 
had ever accepted Beza's doctrine of predestination and its concomitants" and Arminius never made a declaration "of having undergone a theological transition." Bangs goes even further to affirm that "Arminius was not in agreement with Beza's doctrine of predestination when he undertook his ministry at Amsterdam; indeed, he probably never had agreed with it." ${ }^{105}$ W. Stephen Gunter passionately defends Bangs's conclusions, asserting that Arminius's religious influences in his early years were more Catholic than Protestant and that Arminius, before being under the influence of Beza, was in contact with Melanchthon's view on predestination in Marburg. ${ }^{106}$ In a more careful and cautious tone, Stanglin and McCall assert that "it is just as likely that Arminius, as an heir of the early Dutch Reformation, always held a sort of conditional predestination."107

I think that significant evidence likely points to the accuracy of Bertius's account of the history. I do not find logical and/or practical the reasons for Bertius's need to fabricate this account of Arminius's doctrinal development. It seems more probable than not that Arminius was deeply influenced by and even accepted a sort of unconditional view of predestination. First, because while we know little about Arminius's early years of education and his theological views on those days, his preparation for pastoral ministry occurred in the stronghold of the Reformed predestinarian view under the strict supervision of Beza. Indeed, Beza never complained of Arminius holding any

${ }^{105}$ Bangs, Arminius, 141.

${ }^{106}$ Gunter, Arminius and His Declaration, 53. R. Olson also follows Bangs's account of the event, see Arminian Theology, 47.

${ }^{107}$ Stanglin and McCall, Theologian of Grace, 29. 
unorthodox view on predestination. Furthermore, it is well known that Beza gave Arminius his support for pastoral ministry, and Beza was not known to recommend and endorse his students casually. We also do not have any idea of Arminius's theology until his initial writings appeared around $1590 .{ }^{108}$ For these reasons, in his recent popular treatment of Arminius, Rustin E. Brian states that “Arminius certainly learned Beza's theology while in Geneva. There is evidence of other students who strongly objected to Beza's thinking, but it cannot be proved that Arminius was in that camp during his early days as a student at Geneva."

Second, Arminius as a candidate for the pastoral office in Amsterdam was closely examined by the ministers, all of whom where Calvinist. Obviously, such a doctrinal examination would have included his views on predestination. If he was not in agreement with the Reformed doctrine of predestination, how would he have passed the exam?

Third, Franciscus Gomarus strongly opposed Arminius's appointment to the professorship at Leiden. However, after examining Arminius, Gomarus came to the conclusion that Arminius's views at the time were Reformed and that the two men would

${ }^{108}$ See Clarke, The Ground of Election, 13. W. Robert Godfrey came to a similar conclusion - that Arminius probably held Calvin and Beza's view on predestination before 1590. However, Godfrey seems to be trying to make the case that Arminius was just making some trouble for his Reformed professors and ministers. By contrast, I believe that Arminius sincerely came to a different conclusion on predestination after long and carefully considering the evidence from a biblical point of view. See W. Robert Godfrey, "Demythologizing Arminius: A Fresh Look at His Life" (Paper presented at the 66th annual meeting of the Evangelical Theological Society, San Diego, CA, November 19-21, 2004), available at Wordmp3.com.

${ }^{109}$ Rustin E. Brian, Jacob Arminius: The Man from Oudewater (Eugene, OR: Cascade, 2015), 18. However, Brian is doubtful and seems to accept McCall and Stanglin's conclusions that Arminius always had some kind of conditional election view. 
be able to work together. ${ }^{110}$ It seems that at the time, for Gomarus, it was sufficient that Arminius disavowed the views of Prosper Desidaeus [a pseudonym used by Faustus Socinius] and Pelagius. Gomarus affirmed that "he felt himself satisfied, and that his interpretation [Arminius's interpretation of Romans 7,] such as it was, might be tolerated."

Fourth, Gunter quotes a letter of Arminius dated February 7, 1597, in which Arminius confessed that for "no less than seven years he had been 'highly doubtful' (anxie dubito, lit: anxiously doubtful) about Beza's predestination."112 Yet Gunter is somehow inconsistent, for later in his account he affirms that Arminius struggled with Beza's predestination "since at least 1590."113 The letter seems to favor Bertius's account rather than Bangs's and Gunter's for the following reasons: First, the time frame coincides with Bertius's report of the year, 1590, in which Arminius came to a different conclusion. Second, "to be doubtful" or "struggling" does not necessarily mean that Arminius had a conditional view of predestination. It could likely signify that although at the time he shared Beza's view on predestination, he had critical questions about the doctrine of unconditional election. Moreover, if the reading of the ministers "settled nothing," as Clarke concludes, it evidently challenged his assumed presuppositions on predestination, because Arminius expressed his confusion about the matter and later

${ }^{110}$ See Bangs, Arminius, 238.

${ }^{111}$ Works, 1:245-248.

${ }^{112}$ Gunter, Arminius and His Declaration, 54.

${ }^{113}$ Ibid., 70. 
studied to ascertain the truth. ${ }^{114}$ In sum, it is possible that Bertius is wrong about Arminius's changing his view immediately after reading and studying the mentioned pamphlet. However, he is right in connecting Arminius's questioning of his position on predestination with his reading of that pamphlet. In any case, by the time he wrote to Uytenbogaert, Arminius was fully defending a conditional view of election and predestination.

Finally, historians of the Reformation in Netherlands believe that if Arminius was not actually influenced by Coornherts and other "libertarians," they surely shared "interest and cooperation" in critical areas of doctrine after 1590. They infer this from the interesting history of Arminius supporting Theodor Herberts's Gouda Catechism. ${ }^{115}$ In summary, from my point of view the real question is: Why did Arminius agree to write refutations against a view that he already held and in that manner jeopardize his pastoral position and put himself at odds with the leadership of the Reformed Church? A probable answer is that Arminius, if not at the time a Supralapsarian, was at least a moderate Calvinist. Clarke puts it like this: "if asked for his opinion, he would probably have answered in the words of his church's confessional standards, the Belgic Confession and the Heidelberg Catechism. In this sense he might loosely have been described as a 'Calvinist." ${ }^{116}$ His history after the fact demonstrates that he openly and honestly expressed and defended his points of views without fear. If this is not the case, then

\footnotetext{
${ }^{114}$ See Clarke, The Ground of Election, 14.

${ }^{115}$ For more on this, see van Veen and Spohnholz, "Calvinist vs. Libertines," 98.

${ }^{116}$ See Clarke, The Ground of Elections, 14.
} 
Arminius actually had a deceptive character that successfully fooled everyone for a significant period of time.

While I consider Bertius's account a more plausible explanation of Arminius's theological development, once Arminius became doubtful about the Reformed view of predestination, he surely had a rich background from his early studies and theological influences, on the basis of which he could relate to a more conditional view of election. As Bangs argues, Arminius in his early formative years became acquainted with the works of St. John Chrysostom, Basil the Great, Athanasius, Melanchthon, and Erasmus. ${ }^{117}$ As a result, Arminius was under the influence of theological writers who shared a positive view of the role of human freedom of will in salvation while maintaining the anticipation and centrality of God's grace. One could speculate, as Bangs and other argue, that these early studies had an important influence on Arminius's theological thinking and helped him to transition more easily from his Reformed position on election to a positive view of God's prevenient grace and the consequent role of human freed will.

Arminius completed the rest of his professional life teaching theology and Sacred Scripture at the University of Leiden. He joined the faculty of theology of Leiden early in June of 1603 after great controversy, manifest opposition, and detailed examination. ${ }^{118}$ Although some of his detractors tried to stop students from listening to Arminius, ${ }^{119}$ he

117 See Bangs, Arminius, 35.

${ }^{118}$ See Bangs, Arminius, 231-239, 243.

${ }^{119}$ Stanglin, Arminius on the Assurance of Salvation, 27; Brant, The Life of 
rapidly gained the respect and admiration of most of his students. ${ }^{120}$ Arminius

intentionally directed his students to focus on the Holy Scripture as the main and most reliable source for constructing theology. He also encouraged them to construct biblical doctrines that were valuable and practical for the Christian life rather than focus on the speculative aspects and conclusions of Christian theology. Yet this obviously does not mean that he encouraged them to ignore other theological sources from the tradition of the Church, like the Church Fathers and reformers like Calvin. ${ }^{121}$

In summary, while during his professorship Arminius was constantly surrounded by controversy and false accusations that even involved students, he was a successful professor who dedicated the last years of his life to preparing pastors for the Reformed church in Europe.

The Final Days: Controversies and Death

The final years of Arminius's life were full of suffering, illness, and controversies. He continually needed to appear at conferences to confront accusations that he was teaching heresies, mistreating students, and advising the reading of Catholic

Arminius, 169-170.

${ }^{120}$ Brant, The Life of Arminius, 97.

${ }^{121}$ In a letter to Sebastian Egbert dated May 3, 1607, Arminius declares: "After reading of Scripture, which I vehemently inculcate more than anything else . . . I encourage the reading of the commentaries of Calvin, which I extol with greatest praise," quoted in Mark A. Ellis ed. and trans., The Arminian Confession of 1621 (Eugene, OR: Pickwick, 2005), vii; Arminius continually emphasized to his students that the standard for discerning between truth and error is the Holy Scriptures. See Brandt, The Life of Arminius, 189. 
philosophers and scholars. ${ }^{122}$ It is precisely during these final years that he wrote his Declaration of Sentiments in which he rejected in a clear, precise, logical, and succinct way the doctrine of particular redemption or predestination in all its theological manifestations. ${ }^{123}$ It is interesting to note Arminius's theological maturity in his appeals to historical, theological, biblical, and practical arguments to defend his views. For instance, in order to highlight the inaccuracies of predestination, Arminius focuses on anthropological reasons that demonstrate that the constitution of humans as those created in God's image is capable of knowledge, holiness, freedom of will, and enjoyment of eternal life. ${ }^{124} \mathrm{He}$ finally declared his beliefs in front of the magistrates and people of the States of Holland sometime shortly after October 20, 1608. In the midst of such controversies, stressful events, and bitter opposition he fell ill of tuberculosis, whose initial symptoms he had experienced as early as 1604 .

Arminius breathed his last on October 19, 1609. He finally encountered rest from a life "satiated with toils and afflictions." 125 It seems appropriate to close this summary of Arminius's life by quoting Bertius's eulogy: “There lived a man, whom it was not

${ }^{122}$ Brandt, The Life of Arminius, 234.

${ }^{123}$ Arminius rejected both supra- and infralapsarian views of predestination. He believed that both views basically teach that God is the author of evil. He stated that "the objection against the first position (supralapsarianism) is true also of the second (infralapsarianism). Despite every effort, it fails to avoid it [making God the author of sin]." Gunter, Arminius and His Declaration, 134.

${ }^{124}$ See Gunter, Arminius and His Declaration, 115-116.

${ }^{125}$ Oration, in Works, 1:46. 
possible, for those who knew him, sufficiently to esteem; those who entertained no esteem for him are such as never knew him well enough to appreciate his merits."126

\section{Images and Self-Image of Arminius}

Arminius's life, person, character, and ideas have spawned positive as well as negative evaluations. This section does not discuss the great range of scholarly misrepresentation of Arminius's theology; rather, it attempts to portray the kind of man that people have perceived Arminius to have been as well as the kind of images that Arminius had of himself. ${ }^{127}$

On the one hand, there are those who evidently demonstrate a great sympathy and appreciation for Arminius's person and work. Before the controversy erupted, from his student years on, his professors had favorable opinions of him. For instance, Theodore of Beza noted that Arminius enjoyed "an apt intellect" able not only to understand but most importantly to discriminate among ideas. ${ }^{128}$ It is important to note that Beza especially highlighted Arminius's personal virtues of piety and diligence. ${ }^{129}$ Similarly, John James

${ }^{126}$ Oration, in Works, 1:47.

127 The most accessible sources for becoming acquainted with the many and repeated misrepresentations of Arminius's theology are the several myths analyzed by R. Olson in Arminian Theology. See also, R. Olson, "Arminianism is God-Centered Theology," in Grace for All: The Arminian Dynamics of Salvation, ed. Clark H. Pinnock and John D. Wagner (Eugene, OR: Wipf and Stock, 2015), 17; Stanglin and McCall, Theologian of Grace, 6-14.

${ }^{128}$ Brant, The Life of Arminius, 24; "Letter of Beza to the Authorities of the Church in Amsterdam," in Works, 1:24-25.

${ }^{129}$ Ibid. It is interesting to note that Beza, in contrast with Grynaeus, did not mention anything about Arminius's theological and biblical abilities. 
Grynaeus, professor of sacred literature at Basel, says that Arminius had the "gift of a discerning spirit" manifested in theological and biblical discussions and expositions. ${ }^{130}$ Grynaeus also commended him for living "a life of piety and temperance." 131

After the controversy, his sons and daughters, contemporaries and colleagues, and even some adversaries described the Christian and personal character of Jacobus Arminius as irreproachable, mild in spirit, pious, judicious, honest, and candid. ${ }^{132}$ Like some of his professors, many other persons also regarded Arminius as intellectually brilliant and profoundly learned. For instance, Mattias Martinius (1572-1630), ${ }^{133}$ professor of Bremen and delegate at the Synod of Dort (1618-1619), testifies that

${ }^{130}$ Brant, The Life of Arminius, 25; "Letter of Grynaeus to the Authorities of the Church in Amsterdam," in Works, 1:25.

${ }^{131}$ Works, 1:25.

${ }^{132}$ Works, 1:xxxviii-1xiv.

133 Though a Calvinist, Martinius clashed with Gomarus at Dort over the scope of Christ's atonement. He insisted that the death of Christ was for "all particular men," somehow allowing the incorporation of specific features of Arminius's theology without being an exponent of Arminius's concept of free will and resistible grace. So, it is no real surprise that he had a positive view of Arminius's character. A testimony of Martinius' position is found in a letter that Walter Balcanqual sent to Lord Embassador Dudley Carton on February 9, 1618. He explains that the issue at the Synod was whether "the Words of Scripture, which are likewise the Words of our Confession (Chriftus oblatus eft aut mortuus pro toto humano genere, feu pro peccatis totius mundi) are to be understood of all particular men, or only of the Elect, who consist of all sorts of men? Dr. Davenant and Dr. Ward are of Martinius of Breme his Mind; that it is to be understood of all particular men," see Walter Balcanqual, "Dr. Balcanqual's Letters From the Synod of Dort to the Right Honourable Sir Dudley Carlton, Lord Embassador," in John Hales, Golden Remains of the ever Memorable Mr. John Hales, of Eaton-College, with Additions from the Author's Own Copy, vol. 12, 4th ed. (London: E. Pawlet, 1711), 471. For more about the role of Martinius at the Synod of Dort and how his view of covenant theology informed his conclusions on predestination, see McCoy and Baker, Fountainhead of Federalism, 64-69. 
Arminius appeared to him "a man who truly feared God, of the deepest erudition, uncommonly well versed in theological controversies, and powerful in the Scriptures." ${ }^{134}$

It is important always to pay attention to the opinion of family members to truly understand a person. Although in some cases such opinions obviously could be biased, they express in some measure the values and images transmitted by a father or mother to their children. Arminius's children evidently held their father in great esteem. They viewed their father as a man committed "to the practice of a Christian life, and thus that piety and the fear of the divine Majesty uniformly breathed"135 in all his personal, academic, and pastoral works. It seems to me particularly remarkable that his children specifically emphasized the Christian character of their father over any other personal or intellectual characteristics.

A more personal and sympathetic view comes from Hugo Grotius's commemorative poem Elegy on Arminius. Grotius depicts Arminius as a "scrutator altae veritatis" ('searcher of the profound truth') gifted with a "sublime pectus, anima feta doctrinae" ('distinguished heart, soul full of doctrine') that contrasts with the "semicaecae ... turbae" ([ignorant multitude] or 'half-blind crowds of people') of his time. ${ }^{136}$ Moniek van Oosterhout believes that Grotius wrote the poem "out of sympathy

${ }^{134}$ Works, 1:liii.

135 "Dedication by the Nine Orphan Childen of Arminius," in Works, 1:5-12.

${ }^{136}$ For a complete Latin version and English translation of Grotius's poem, see Moniek van Oosterhout, "Hugo Grotius in Praise of Jacobus Arminius: Arminian Readers of An Epicedium in the Dutch Republic and England" in Literary Cultures and Public Opinion in the Low Countries, 1450-1650, ed. Jan Bloemendal, Arjan van Dixhoorn, and Elsa Strietman (Leiden, The Netherlands: Brill, 2011), 174-175. 
for Arminius and his ideas." ${ }^{137}$ She also notes that the poem depicts Arminius "as a sympathetic man who strove for a sympathetic ideal in an indefatigable manner.",138 Similarly to Grotius, Joseph Justus Scaliger, one of Arminius's colleagues at Leiden and a respected scholar, opined that "Arminius est vir maximus" (Arminius is the greatest man). ${ }^{139}$ Although it is not possible to know whether Scaliger was referring here to Arminius's character or to his intellectual virtues, obviously he did not consider Arminius a mediocre scholar or characterless person. It is possible that Scaliger viewed Arminius as "a seeker, a doubter" ${ }^{140}$ completely imbued in the spirit of ecclesia reformata, semper reformanda. Most recently, orthodox Calvinist theologian Charles Hodge described Arminius as a "man of learning, talents, attractive accomplishments, and exemplary character" and even tried to distance Arminius from the most liberal opinions of his successors. ${ }^{141}$

${ }^{137}$ van Oosterhout, "Hugo Grotius in Praise of Jacobus Arminius," 156.

${ }^{138}$ Ibid., 159.

${ }^{139}$ According to Bangs, this was a significant commendation especially because it came "from a man who praised almost no one." However, it is necessary to be cautious about this praise because Scaliger referred to Arminius's opponent Junius as an "ass" and "dumbhead." He also regarded Gomarus as one "who talks about everything that he does not understand," Bangs, Arminius, 244-245. Such biased opinion could show that for whatever reasons, either theological or personal, Scaliger had a penchant in favor of Arminius.

${ }^{140}$ Edwin Rabbie, "General Introduction" in Hugo Grotius, Ordinum Hollandiae ac Westfrisiae pietas (1613); Critical Edition with English Translations and Commentary, ed. Edwin Rabbie, in Studies in the History of Christian Thought, ed. Heiko A. Oberman, vol. 66 (Leiden, the Netherlands: Brill, 1995), 3.

${ }^{141}$ Charles Hodge, Systematic Theology (Grand Rapids, MI: Eerdmans, 1952) 3:185-186. 
On the other hand, however, we find hostile opinions regarding Arminius's character, theology, and life. I will summarize them using three principal images of Arminius. First, Petrus Plancius (d. 1622) regarded Arminius as a Pelagian heretic. ${ }^{142}$ In the same vein, years later, James Murdock called Arminius the father of a heretical sect and a teacher and fabricator of novel theology. ${ }^{143}$ Murdock thus perceived Arminius as an insensitive scholar only interested in promoting his own theological agenda. Accusations of heresy in the sixteenth century were not only dangerous; heretics were rhetorically and personally construed as servants of errors, as possessed by the devil, as destroyers of the social order, and as "wicked hypocrites within the flock of the good." reflected not only the approach of Roman Catholic inquisitors toward heretics, but also the way in which some Protestant leaders reacted against opponents. According to

${ }^{142}$ The identification of Arminius as a Pelagian or semi-Pelagian remains a common misrepresentation of Arminius's theology. For instance, Stanley J. Grenz affirms that "Arminius reasserted the semi-Pelagian position that Adam's offspring do not share in the guilt of the sin of our first parents." In the context, Grenz clearly equates guilt of sin with inherited depravity. See Stanley J. Grenz, Theology for the Community of God (Grand Rapids, MI: Eerdmans, 2000), 200.

${ }^{143}$ James Murdock, Mosheim's Institutes of Ecclesiastical History, Ancient and Modern, revised by James Seaton Reid (London: William Tegg, 1878), 843.

Interestingly, Jonathan Edwards spread the same opinion calling Arminius the person responsible for sectarian teachings within the Reformation. Indeed, Edwards presents a large list of events and persecutions by which Satan unsuccessfully tried to destroy the Reformation and reserves to the end "corrupt opinions" including those of the Anabaptists, Socinians, Arians, and obviously Arminius and his followers; Jonathan Edwards, A History of the Work of Redemption, in The Works of Jonathan Edwards, vol. 1 (New York: Leavitt \& Allen, 1856), 466-467.

${ }^{144}$ Wim Balke, "Calvin and the Anabaptists," and Mirjam G. K. van Veen "Calvin and His Opponents," in The Calvin Handbook, ed. Herman J. Selderhuis, trans. Henry J. Baron, Judith J. Guder, Randi H. Lundell, and Gerrit W. Sheeres (Grand Rapids, MI: Eerdmans, 2009), 151, 162, 163. 
Mirjam van Veen, to depict heretics as under the influence or possession of evil spirits was an integral part of the medieval narrative of heresies and was effectively used to antagonize opponents during the sixteenth century. ${ }^{145}$ Therefore, identifying Arminius as a heretic was an effective way to diminish the influence of his person and of his theological conclusions.

Second, another repeated image of Arminius is that of a traitor of the Reformed cause who secretly served the interests of Rome. ${ }^{146}$ His opponents used Arminius's journey to Rome before returning to his pastoral responsibilities to accuse him of secretly holding sympathies for Roman Catholic theology ${ }^{147}$ For instance Gomarus, while using the same Catholic scholastic sources, unfairly identified Arminius's theology with the Catholic teachings of Biel and Molina, among other Catholic scholars. ${ }^{148}$

Third, perhaps Arminius's delay in clearly and publicly expressing his opinions led Gomarus to picture him as a cunning deceiver who in public maintained an opinion while secretly teaching perilous heresies. I. Schöffer concludes that for Gomarus, “Arminius was a cowardly twister." ${ }^{149}$ However, in his Declaration of Sentiments

${ }^{145}$ Mirjam van Veen, ““. . . la cause des puissans . . .' Sebastian Castellio’s picture of John Calvin," in Reformed Majorities in Early Modern Europe, ed. Herman J. Selderhuis and J. Marius J. Lange van Ravenswaay (Göttingen, Germany: Vandenhoeck \& Ruprecht, 2015), 291.

${ }^{146}$ Bangs, Arminius, 78-79; Stanglin and McCall, Theologian of Grace, 8.

${ }^{147}$ Bertius, Oration, in Works, 1:26-27.

${ }^{148}$ Stanglin, Assurance of Salvation, 82n38; 83n41.

${ }^{149}$ I. Schöffer, "De crisis van de jonge Republiek 1609-1625," in Alegeme Geschiedenis der Nederlanden, ed. J. A. van Houtte, J. F. Niermeyer and J. Presser, VI 
Arminius makes clear that his delay in responding about his beliefs was not an attempt to deceive about the real content and intentions of his teachings and opinions on predestination. Rather, he was trying to maintain the ecclesiastical and governmental order, protect his reputation from evidently biased requests, avoid unfair process, and avert disruption in the churches and universities by those improperly presenting his ideas. $^{150}$

Nevertheless, the notion that Arminius was a blatant liar or at least an unintentional deceiver has continued to be disseminated, sometimes consciously and in other instances unconsciously. Some have noted, for instance, the uncompleted picture that Bradley and Muller present about Arminius's use of catholic sources. Bradley and Muller say that historians "must recognize that documents can and sometime will intentionally or unintentionally stand in the way of clear understanding of their author's mind." They regard Arminius as a classic example of such a conclusion, saying that Arminius's statement that he never recommended Catholic writers to his students "mask[s] his significant appreciation and use of the writings of Tomas Aquinas, Francis Suárez, and Louis Molina - all scholastics, and the latter two, Jesuits," In this case, they transmit the wrong perception that Arminius was trying to hide his personal interest and

(Utrecht, 1953), 2-3; cited by Edwin Rabbie, "General Introduccion," in Hugo Grotius, Ordinum Hollandiae Ac Westfrisiae Pietas (1613); Critical Edition with English Translation and Commentary, in Studies in the History of Christian Thought, ed. Heiko A. Oberman, vol. 66 (Leiden, the Netherlands: Brill, 1995), 3n4.

${ }^{150}$ Arminius, Declaration of Sentiments, in Gunter, Arminius and His Declaration, 98-103. 
reading of these authors. These kinds of assumptions effectively perpetuate the image of Arminius as a deceiver. ${ }^{151}$

In reality, Arminius in a letter to Ubbo Emminus denied "having recommended reading Bellarminus [Cardinal Robert Bellarmine] or any Roman Catholic author to my students." "152 However, this was not an attempt to "mask" his own personal reading of such writers. He was just making clear that if his students were reading Catholic scholars, it was not under his direction or by his recommendation. This seems a more truthful explanation, because when necessary he openly quoted Bellarmine, Aquinas, and other Jesuits in his own writings. Sometimes, he agreed with their conclusions, at other times he fiercely opposed their teachings. In the same letter to Emminus he affirms: "Thomas, Scotus and the entire flock of scholastics, however they may excel philosophically, are blinder than bats in their exegesis of Scriptures, as I have frequently demonstrated, shedding light on their ignorance to deprive them of any authority." 153 This demonstrates

${ }^{151}$ Bradley and Muller, Church History, 36-37, 50; see also Muller, "Arminius and the Scholastic Tradition," 266. In any case, Arminius was not the only professor in Leiden who appreciated and even recommended medieval Catholic scholars to their students. Narrating the first one hundred years of Leiden University, Elfriede Hulshoff Pol concludes that "Gomarus accuses Arminius of introducing Thomas Aquinas, Suarez, and Bellarminus into Leiden, to which Bertius was able to reply that they had been favored at Leiden long before Arminius' arrival. Although no one can have known better than Bertius that the works in question were available in the Library, it is noticeable that he does not say so outright but in the less exact terms 'were in vogue,' adding that Franciscus Junius had also recommended them to the young students," Elfriede Hulshoff Pol, The First Century of Leiden University Library (Leiden, the Netherlands: Brill, 1975), 436.

${ }^{152}$ Arminius, "Letter to the Groningen rector Ubbo Emminus, dated 18 May 1608 " quoted in Eric H. Cossee, "Arminius and Rome," 81.

${ }^{153}$ Quoted in Cossee, “Arminius and Rome,” 81. 
that while he shows appreciation for the philosophical work of the scholastics, at the same time he was completely unenthusiastic regarding their exegetical and theological methods and conclusions.

Unfortunately, these images of him as a heretic, traitor, and deceiver especially vilify Arminius's integrity and Christian character. However, not all that his opponents had to say about him were insults. Interestingly, Arminius's antagonists never questioned his intellectual and Christian aptitudes, for example his "ingenuity, acuteness, and piety." 154

Although recent interpreters of Arminius have not paid close attention to Arminius's image as a person, and have instead tended to emphasize his intellectual capacities and theological work, it could be said that a more balanced image of him is now prevalent thanks to recent studies of Arminius's life and work. F. Stuart Clark views Arminius not as a combative scholar, but as a reluctant theologian with a modest opinion of his own ideas, as one open to suspending judgment about controversial aspects of theology, and willing to change his points of view when evidence demanded it. ${ }^{155}$ Stanglin and McCall say that he was a man who always fearlessly defended his opinion but that he did so with "political circumspection." 156 However, they argue that he was neither a saint nor a malicious heretic. Similarly James D. Douglas affirms, "a mildtempered man, Arminius nonetheless spoke his mind in controversy" and passionately

\footnotetext{
${ }^{154}$ Murdock, Mosheim's Institutes, 838.

${ }^{155}$ Clarke, The Ground of Election, 12.

${ }^{156}$ Stanglin and McCall, Theologian of Grace, 19.
} 
defended his views. ${ }^{157}$ In sum, the new image of Arminius portrays him as an irenic thinker, but one who did not hide from controversy and even to some extent sought it out.

The foregoing is how Arminius's professors, friends, opponents, and interpreters perceived him. How did Arminius view himself? I do not pretend here to develop a complete self-image of Arminius, but I do intend to highlight some aspects of how Arminius viewed himself as person, Christian, and theologian.

Primarily, Arminius viewed himself as a Christian, specifically a faithful Reformed Christian. Traces of his own image of Christian character can be found throughout his writings. On the one hand, Arminius expressed a teachable and docile spirit, open to being corrected by the Scriptures and by reason. He promised always to conduct himself "with equanimity, moderation, and docility" in the spirit of one "being taught." ${ }^{\text {158 }}$ In a letter to Drusius, one of his teachers at Leiden, he stated great appreciation for those who were open to changing their opinions when sufficient arguments had been presented. ${ }^{159}$ In this context he was said to be a friendly person who longed to have "amicable and fraternal conferences" with all divines about any biblical and theological issues. ${ }^{160}$ On the other hand, although he showed openness to maintaining friendly relationships and to changing his opinions, he made it clear that he had strong

${ }^{157}$ James D. Douglas, “Arminius, Jacobus (1559-1609)” in Who's Who in Christian History, ed. J. D. Douglas and Philip W. Comfort (Wheaton, IL: Tyndale House, 1992), 37.
${ }^{158}$ Decl. Sent., in Works, 1:731.
${ }^{159}$ Cited by Clarke, The Ground of Election, 11.
${ }^{160}$ Ibid. 
ideas and opinions, which he was not ready to give up easily without a compelling reason. This is obvious in the frequent use of expressions like "I am of the opinion," "I am still of the same opinion," "I am enabled to affirm," "I am prepared to maintain this very thing," and so forth. All this illuminates Arminius's self-image of his character and personality. It is also interesting to note his descriptions of a good minister of God. He shows great appreciation for qualities of character like "prudence, moderation of mind, and patient endurance of labors, infirmities, [and] injuries." ${ }^{161}$ To the modern reader, the description might only be a construction of the ideal minister, but it seems to me that Arminius was evidently describing his own ministry and character. This seems obvious from his frequent call for prudence when considering biblical and theological evidence.

As a theologian and pastor, Arminius viewed himself as a faithful exponent of the Holy Scriptures. He also believed that he was a loyal minister of the Reformed Church and its declarations of faith, the Heidelberg Catechism and the Belgic Confession. He wrote to Hippolitus A. Collibus that "I have never taught anything, either in the church or in the university, which contravenes the sacred writings that ought to be with us the sole rule of thinking and speaking [Holy Scriptures], or which is opposed to the Belgic Confession or to the Heidelberg Catechism." 162 Interestingly, he used the confession and the catechism as sources not only in agreement with his own point of view, but also as opposing the predestinarian views of his opponents. Some have seen this reality as a bigger inconsistency of Arminius because he himself called for a revision of the Church's

${ }^{161}$ Priv. disp., LIX, in Works, 2:434.

${ }^{162}$ Hippolytus Lett. in Works, 2:690. 
doctrinal standards. However, an analysis of his arguments in favor of the revision demonstrates that his call to reform the confession and the catechism was in order to achieve, first, precision and clarity and avoid some ambiguities in the text as well as to improve the languages with a more biblical tone, ${ }^{163}$ and second, to call attention to the Holy Scriptures as the only norma of doctrine and faith.

Arminius boldly declared that "no writing composed by men,--by one man, by

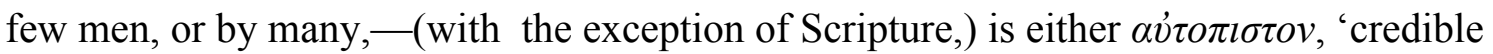
of itself' or $\alpha \xi \xi$ Łó $\iota \sigma \tau o v$, 'of itself deserving of implicit credence,' and, therefore, is not exempted from an examination by means of the Scriptures." ${ }^{" 164}$ Indeed, making the Scripture the ultimate rule only when it is interpreted by the standards of the human confessions embodies the tyrannical attitude of the traditional church. As Henk van den Belt puts it: "For Arminius the autopistia of Scripture safeguards the liberty of the biblical exegete and theologian from the authority of the human confessions." Assuming this position Arminius submitted himself, all other interpreters, and the Church to the supreme and ultimate authority of Scriptures.

\section{Arminius's Theological Method}

It seems necessary to consider Arminius's theological method before we finish the present historical review of his life and work. Arminius maintained a high view of

${ }^{163}$ Decl. Sent., in Works, 1:701-730.

${ }^{164}$ Art. 1, in Works, 2:706.

${ }^{165}$ Henk van den Belt, The Authority of Scripture in Reformed Theology: Truth and Trust (Leiden, The Netherlands: Brill, 2008), 147. 
Scripture as the inspired word of God and as the infallible, authoritative, and sufficient rule of Christian faith and life. Evidence of this is his statement that the Holy Scriptures contain "the rule of our faith, charity, hope, and of the whole of our living. For they are given for doctrine, for reproof, for instruction, for correction, and for consolation; that is, that they may be the rule of truth and falsehood to our understanding of good and evil to our affections, either to do and to omit, or to have and to want." ${ }^{, 166}$ Here Arminius expresses his total commitment to the sola scriptura principle of the Reformers. He also saw the necessity to read the whole of Scripture, supporting the tota scriptura principle. He said that faith could not have existence without regarding the "Scriptures of the Old and the New Testament" as divinely inspired and containing "the sum of the Law and the Gospel." ${ }^{167}$ In the following analysis, we will see that he also maintained the principle of prima scriptura, yet giving a place to other sources of truth to have, at least, an ancillary role in biblical interpretation.

So how might we define Arminius's biblical hermeneutic? I identify Arminius's theological method as a biblical theology that is informed by a careful exegetical approach to Scripture and analysis of the theological tradition of the Church. First, Arminius would say that biblical teaching should be discovered in the literal reading of the Bible, the "signs," that is, in the words of Scripture, but most precisely in the

${ }^{166}$ Pub. Disp., I, in Works, 2:82. See also, Orat. 3, in Works, 1:374-401; Pub. Disp. II and III, in Works, 2:92-111.

${ }^{167}$ Pub. Disp. I, in Works, 2:84. 
"[sensus $]$ meaning" of those words. ${ }^{168}$ The task of interpretation is a critical one to be made by experts such as pastors and teachers trained in "languages and divine things."169 Similarly, Arminius says that hermeneutics is an approach to the biblical doctrine and text that demands an interpreter "who is well skilled in the two sacred languages, has a perfect knowledge of all tradition, [and] has perused with the closest attention the writings of all the great Doctors of the Church." ${ }^{, 170}$ Throughout his writings, Arminius time and again emphasizes the importance of familiarity with the biblical languages when analyzing Scripture as well as having an understanding of the history of theological constructions. ${ }^{171}$

For instance, an analysis of his interpretation of Romans 7 shows the consistency with which he applied this method. He divided his study into five parts. The first part is an exegetical approach to Romans 7 done almost verse by verse that carefully considers the context of the passages, the crucial words and terms, the syntactical connections, and even the inter-textual significance of the texts. The second to the fourth parts are a thorough presentation of evidence in favor of his exegetical conclusion from the early

${ }^{168}$ Pub. Disp. I, in Works, 2:82.

${ }^{169}$ Ibid.

${ }^{170}$ Orat. 5, in Works, 1:442-443.

${ }^{171}$ My observations of Arminius's use of tradition agree with the conclusions of Jeremy Dupertuis Bangs that "Arminius maintained a positive role for tradition, including councils, as witnesses to the divine truth of the Bible. Councils could err, but they did not necessarily err." See Dupertuis Bangs, "Beyond Luther, Beyond Calvin, Beyond Arminius: The Pilgrims and the Remonstrants in Leiden, 1609-1620," in Reconsidering Arminius: Beyond the Reformed and Wesleyan Divide, ed. Keith D. Stanglin, Mark G. Bilby, and Mark H. Mann (Nashville, TN: Kingswood and Abingdon, 2014), 45. 
church fathers, medieval theologians, and contemporary reformers. The final part responds to several objections and presents Arminius's conclusions.

Second, Arminius also examined several theological or doctrinal topics following not so much an exegetical approach to particular texts, but rather a canonical analysis of Scriptures. In such instances, he presents some specific propositions and then proceeds to prove them, first, by referring to specific passages of Scripture, and second, by arguments and reasons deduced from the biblical passages. ${ }^{172}$ Such topical analysis frequently follows the Aristotelian framework of the four causes - the formal, material, efficient, and final. It is precisely in this methodology that Arminius shows his use of the scholastic method in theological conceptualization. I have found that this theological method is common throughout his Orations and Public and Private Disputations. In these cases, Arminius exhibits a great ability to present logical and syllogistic arguments in favor of his conclusions. Obviously, this second approach should not be completely disassociated from the previous one. Frequently, Arminius combined both approaches in his biblical and doctrinal conceptualizations. Recently, Jeremy Dupertuis Bangs noted this combination of logic, syllogism, and biblical languages in Arminius's interpretation of Scripture. According to Dupertuis Bangs, this is especially present in Arminius's use of

${ }^{172}$ For instance, see the argument of Arminius using deductive logic against predestination from the major proposition, "creation is a communication of that which is good" followed by the principal arguments to support his main premise, Gunter, Arminius and His Declaration, 116; see also Arminius main premise that, "all things necessary [for salvation] . . . have been inspired into the apostles, and that no new inspiration has since their times been communicated, and that it will not be in future" followed by a series of arguments from particular biblical passages and deductions from them, Pub. Disp. II, in Works, 2:95. 
Jacomo Zabarella's methodology of composition (deductive reasoning) and resolution (inductive reasoning). ${ }^{173}$ Dupertuis Bangs affirms that Zaberalla's approach gave Arminius and other Protestants scholars at the time "a way to test Scripture against Scripture in order to determine the right interpretation without dependence on papal authority and Catholic tradition." 174

In conclusion, Arminius's theological method was scholastic, complex, solid, and systematic. Scriptures played a major role in his alternative understanding of divine election, grace, and human freedom of will. At the same time, he followed a methodological approach analogous to that of his contemporaries in his discovery of the biblical truth. ${ }^{175}$ What was particular to Arminius's hermeneutics was the Christological focus that he used in the reading of Scripture within the features of the scholastic method.

\section{Summary and Conclusion}

Arminius's life and work is a fascinating history of struggles, sufferings, success, and controversies at the intersection of his pastoral and academic career. Although he experienced atrocious events during his childhood, he succeeded in his intellectual life and ministry with the help of influential benefactors. These benefactors provided financial and emotional support to the young student, thus enlarging his circle of influence and opportunities. For this reason, Arminius enjoyed what was at the time a

${ }^{173}$ Dupertuis Bangs, "Beyond Luther, Beyond Calvin, Beyond Arminius," 44, 46. ${ }^{174}$ Ibid., 44.

${ }^{175}$ Stanglin and McCall, Theologian of Grace, 11. 
rare privilege to study at the finest centers of education of his days under well-known Protestant scholars. Despite the controversies, Arminius developed a fruitful pastorate in Amsterdam, and won the appreciation of his parishioners for his pastoral care and preaching. Likewise, all accounts seem to indicate that he was also a great teacher capable of transmitting his love for the Holy Scriptures and Christian theology to his students. Sadly, he died in the middle of the controversy without witnessing the outcome for which he had worked so long: a general council of the Reformed Church in the Netherlands to resolve in a frank and Christian manner the dissension regarding the doctrine of predestination. In addition it seems to me that what likely pained him most to leave unresolved at his death was the accusation of heresy made against him.

His historical context was a turbulent and volatile one. Political, religious, and social struggles marked his pastoral and theological work. However, Arminius was able to navigate the turbulent waters. He built political connections with powerful individuals in the government like Oldenbarnevelt. This raises the question: How much did his political connections help Arminius to avoid the formal condemnation of the Reformed Church in the Netherlands? Even if it was not crucial, it was surely helpful. He also managed to profit theologically and doctrinally from the different religious groups of his age. At the same time, he remained critical of many of the Papal teachings and some of the Anabaptist ideas. However, the differences between his own theology and religious tradition were not for Arminius a reason to persecute and condemn the religious sentiments of other individuals. He consistently advocated for some kind of religious tolerance and acceptance of others' views. 
Arminius's character developed under the supervision of pious professors and friends. His humility, kindness, integrity, piety, and gentleness helped him to confront controversies and sometimes dishonest accusations with a Christian spirit and peaceful manner. When his adversaries lacked real arguments and devolved into making virulent ad hominem attacks against him, he did not respond in the same way but remained focused on the biblical, theological, and logical reasons that supported his opinions. This does not mean that he was a perfect human being. On some occasions he delayed responding clearly about his theological positions, and for that reason some of his contemporaries believed that he was a deceitful hypocrite. However, it seems more probable that he told the truth while explaining his reasons as an attempt to avoid controversies. Surely he did not desire to divide the Reformed church. Indeed, he always spoke as a faithful pastor and theologian of the Reformed confession.

Through his theological contributions Arminius desired to promote a faithful reading of Scripture, a biblical defense of God's character of love and goodness, and a way for all human beings to open their hearts to the divine work of salvation. Though he read the Bible for its plain meaning, at the same time he also promoted a hermeneutic that carefully considered the sensus of the biblical words. Besides that, he always welcomed the theological contributions of scholars from different times and traditions. However, he cautiously compared the conclusions of those theologians with the biblical claims. For instance, this approach allowed him to accept some of Augustine's conclusions, but at the same time to critique unwarranted assertions of the famous church father. His antipredestination sentiments were not those of an isolated thinker. He was an integral part of a wider context of free will thinkers and opponents of Calvin and Beza's 
conceptualization of double predestination. Certainly, he did not radically reject

predestination and divine election, but he constructed a view that was consonant with the tradition of early thinkers and his own understanding of the Holy Scriptures.

Historical studies about Arminius have received renewed impulse and success in recent years. As Stanglin says, there remains however the necessity to translate the historical research into theological and doctrinal conceptualizations in conversation with the historical Arminius and his writings. ${ }^{176}$ This is key because Arminius's theological and biblical influence extended beyond Wesley and the Methodists to "many Christians today." ${ }^{177}$ For instance, many in my own Seventh-day Adventist tradition are somehow unaware of Arminius's influence on our theology. Yet one key church source affirms that: "While Seventh-day Adventists do not formally identify themselves as Arminians, the general Arminian point of view has come to characterize their doctrine." ${ }^{178}$ It is precisely from a stance of systematic and doctrinal conversation that this dissertation tries

${ }^{176}$ Keith D. Stanglin, “Arminius Reconsidered: Thoughts on Arminius and Contemporary Theological Discourse for the Church Today," in Reconsidering Arminius: Beyond the Reformed and Wesleyan Divide, ed. Keith D. Stanglin, Mark G. Bilby, and Mark H. Mann (Nashville, TN: Kingswood Books, 2014), 161-162.

${ }^{177}$ Bangs says "there are many Christians today whose whole religious thinking has been molded [consciously or unconsciously] by the Arminian tradition." Bangs, “Arminius: An Anniversary Report," Christianity Today 5 (10 October, 1960): 19.

178 “Arminianism," in Seventh-day Adventist Encyclopedia, ed. Don F. Neufeld, rev. ed. (Washington, D.C.: Review and Herald, 1976), 80. Unfortunately, the Encyclopedia mistakenly claims that for Arminius human cooperation in salvation rested in the fact that "individuals are not completely depraved." This idea is completely foreign to Arminius's conceptualization of the relationship between God's grace and human free will. 
to make a contribution by providing a study of Arminius's doctrine of prevenient grace in discussion with Arminius's person and writings. 


\section{CHAPTER 3}

\section{HISTORICAL BACKGROUND OF THE DOCTRINE OF PREVENIENT GRACE}

\section{Introduction}

In modern theological thought, the doctrine of prevenient grace is typically identified with the doctrinal views of Jacobus Arminius. Certainly, Arminius used the concept of prevenient grace extensively for his soteriological conceptualizations, yet he was neither the creator nor the unique promoter of prevenient grace. Rather, this theological concept has a history in the development of Christian doctrine since Augustine used it in his controversy with Pelagius in the fifth century. The principal aim

of this section is to trace the history of the doctrine of prevenient grace from Augustine to Arminius's own time. It will give a brief overview of the development of the concept of prevenient grace before Arminius.

First, the study explores the doctrine of prevenient grace in Augustine within the Pelagian controversy. Second, it attends to the principal conceptualizations of that grace during the time of the medieval church. Then, it focuses on the Protestant Reformers, especially Philip Melanchthon and the Anabaptist preachers. The similarities and differences as well as the significance of the concept of prevenient grace will be shown for the theology of each group. This section does not primarily claim that Arminius was directly influenced by all these previous conceptualizations. Yet it provides some of the 
sources that likely influenced Arminius in his own theological understanding of

prevenient grace.

\section{The Beginning of the Christian Concept of Prevenient Grace}

In Augustine of Hippo the theological conceptualization of prevenient grace found its primary interpreter. For this reason, any consideration of the beginning point of the development of prevenient grace has to consider Augustine. Therefore, in this section I pay attention to the contributions of Augustine to the doctrine of prevenient grace, especially in his anti-Pelagian writings.

\section{Saint Augustine of Hippo}

Augustine was born in Thagaste, North Africa in 354 A.D. A combination of an acute power of reasoning, uncommon intellectual capacity, excellent academic preparation, and mystical conversion to Christianity gave Augustine the necessary skills to become a theological genius. As a church apologist he antagonized Arians, Manicheans, Donatists, and Pelagians during his long career as a bishop. ${ }^{1}$ This study examines his concepts of salvation, which were mostly constructed in the stormy

${ }^{1}$ Peter Brown, Augustine of Hippo: A Biography (New York: Dorset, 1986), 3545; 340-375; Eugene TeSelle, Augustine (Nashville, TN: Abingdon, 2006), 1; Mary T. Clark, Augustine (London: Geoffrey Chapman, 1994), 1-12; William A. Sumruld, Augustine and the Arians: The Bishop of Hippo's Encounters with Ulfilan Arianism (Cranbury, NJ: Associated University Presses, 1994), 62-84; Louis Sébastien, The Life of Augustine: Childhood to Episcopal Consecration 354-396, trans. Frederick Van Fleteren (New York: Peter Lang, 2010), 210-216; Warren T. Smith, Augustine: His Life and Thought (Atlanta, GA: Knox, 1980), 55-59, 123-139. 
controversy with Pelagius, paying special attention to the doctrine of prevenient grace.

Augustine was the first significant Christian articulator of this doctrine.

For Augustine, the doctrine of prevenient grace plays an essential role in preserving what he regarded as a critical concept of Christianity: the idea of God's initiative in the salvation of humanity. This doctrine arose in consideration of the role of human will in relation to God's grace in the work of salvation before and within the Pelagian controversy. ${ }^{2}$ This connection makes it important to consider the teaching of Pelagius concerning freedom of will and grace before discussing Augustine's conceptualization of the doctrine of prevenient grace.

According to Pelagius, a strongly moralist British monk, human beings enjoy a natural freedom of will. Freedom of will, for Pelagius, is an original endowment in human nature, a gift of God's grace at creation. ${ }^{3}$ Consequently, humans have the natural ability to accomplish the divine will expressed in the commandments by their own choice and power. In this manner, Pelagius assumed the negation of the doctrine of original sin as well as the doctrine of total depravity. ${ }^{4}$ In his commentary on Romans, Pelagius

2 J. Patout Burns, "Prevenient Grace" in Encyclopedia of Early Christianity ed. Everett Ferguson (New York: Garland, 1990), 753-754; Dennis R. Creswell, St. Augustine's Dilemma: Grace and Eternal Law in the Major Works of Augustine of Hippo (New York: Peter Lang, 1997), 71-76.

${ }^{3}$ Henry Chadwick, The Church in Ancient Society: From Galilee to Gregory the Great (New York: Oxford University Press, 2001), 448-449; Robert E. Evans, Pelagius: Inquiries and Reappraisals (New York: Seabury, 1968), 92-95; Juan B. Valero, Las bases antropológicas de Pelagio en su tratado de las Expositiones (Mardrid, España: Publicaciones de la Universidad Pontifica Comillas, 1980), 183-198; 311-325.

${ }^{4}$ Theodore de Bruyn, "Introduction," in Pelagius's Commentary on St Paul's Epistle to the Romans, trans. Theodore de Bruyn (New York: Oxford University Press, 
insisted that "Adam killed only himself." In this manner, he discredited the concept of original sin affirming that human sin is not the result of an inherited polluted nature from Adam, but the result of human imitation of Adam's offense. ${ }^{6}$ Likewise, he questioned a supposed depravity in humans insisting that they "are whole ... not affected with an inescapable controlling sinful nature to which they are powerless because of Adam's $\operatorname{sin.,"7}$

Though weakened by the constant practice of sin, human will is completely capable of accepting, rejecting, and performing both evil and good. In other words, the power of will is a natural, inalienable, and gratuitous gift of God, but to will and fulfill spiritual and moral good remains the role of individuals. ${ }^{8}$ Pelagius stated: "we must

1993), 23. Bruyn says that Pelagius rejected the concept of the transmission of guilt as well as the concept of the transmission of a natural inclination to sin. Sin is transmitted only by example. Adam provided that sinful example. For a discussion on Pelagius's view on original sin see also B. R. Rees, Pelagius: A Reluctan Heretic (Wolfeboro, NH: Boydell, 1988), 56, 76.

${ }^{5}$ Pelagius, Pelagius's Commentary on St. Paul's Epistle to the Romans, trans. Theodore de Bruyn (New York: Oxford University Press, 1993), 94.

${ }^{6}$ John Ferguson, Pelagius (Cambridge, England: W. Heffer and Sons, 1956), 54.

${ }^{7}$ Pelagius, On Nature, trans. and recons. Daniel R. Jennings, Patristic in English, accessed March 21, 2017, http://www.seanmultimedia.com/Pie_Pelagius _On_Nature.html. §19.

${ }^{8}$ Pelagius, Defense of the Freedom of the Will, trans. and recons. Daniel R. Jennings, Patristic in English, accessed March 21, 2017, http://www.seanmulti media.com/Pie_Pelagius_Defense_Of_The_Freedom_of_The_Will.html. §72-74. Pelagius defended his view by separating "ability," "volition," and "actuality" in the human actions. The ability is the natural power of will implanted in humanity by God at creation, the volition and the actuality belong naturally to individuals. The first is a gift of God's grace, the latter are the exercise of human own nature and power. God's grace should be recognized by the "ability" to do good, while humans have only the "actuality" 
understand that it is of us not to sin, but yet that the ability to avoid sin is not of us [but of God] ... [yet] inasmuch as not to sin is ours, we are able to sin and to avoid sin." ${ }^{9}$

Consequently, for Pelagius, grace as a natural endowment from creation and an external help plays a role in overcoming sin, but further grace does not have a salvific role in human redemption. ${ }^{10}$ Humans rightly merit praise or blame according to their free decisions and actions. In classical Pelagian soteriology human beings are capable of looking to God and choosing the spiritual good without any internal aid or influence.

For Pelagius, therefore, there is neither room nor need for God's prevenient grace as an internal healing power necessary for regeneration and liberation of human freedom of will. However this does not mean that grace is not essential in Pelagius's soteriology,

to do good. J. N. D. Kelly, Early Christian Doctrines (New York: Harper One, 1978), 358.

${ }^{9}$ Pelagius, On Nature, §50. Pelagius recognized in every human action three elements: "posse," "velle," and "esse." The "posse (power)" is already present in our nature as an ability granted by God; the "velle (desire)" is present in our will; finally, the "esse (realization)" is the actual realization of the action. Then, humans have the power "not to sin" because they have received from God the ability "to avoid sin." Properly using their will they are able reach the realization of the action, that it is "to sin" or "to avoid sin."

${ }^{10}$ It is possible to divide the meanings of grace for Pelagius into two main groups. First, grace is preexistent in the human soul as a natural endowment of freedom of will by the act of creation. Second, grace is God's external help to sinners present in the law of Moses, the life and teaching of Christ, the forgiveness of sins by Christ's death and merits, and God's teachings and revelations. In this last meaning of external grace, he is most probably referring to the Holy Scriptures as well as the life of Jesus. He says, "we do not, as you think, confess the grace of God consisting only in the law, but also in the help of God. God helps us through his teaching and revelation, in that he opens the eyes of our hearts, in that he makes clear to us the things to come lest we be occupied in things of the present, in that he exposes the snares of the devil, in that he enlightens us with the manifold and unspeakable gift of heavenly grace," see On Free Choice, quoted in Evans, Pelagius, 110. 
only that grace always operates externally. For Pelagius, there are divine persuasions; there are the requirements and threats of the law, and there is the Holy Spirit calling, inviting, appealing, and admonishing. However, humans overcome sinful habits by actualizing their natural free will in response to the external admonitions of grace. Consequently, the problem in Pelagius's understanding of grace lies primarily not in his negation of grace or his understanding of external grace but in the relation of human free will to grace; and more precisely in his understanding of the consequences of Adam's fall. It seems safe to say that the problem with the concept of grace in Pelagius's soteriology is limited to his rejection of the internal operation of grace. For instance, Arminius succinctly describes Pelagian heresy as the teaching that "with the exception of the preaching of the Gospel, no internal grace is required to produce faith in the minds of men." ${ }^{, 11}$ Consequently, Pelagius rejected a role for an internal healing of grace because humans by creation enjoy flawless free will as a gift of grace. Therefore, Adam's fall did not represent a disruption of this natural gift. Humans are born without a polluted will, and without tendencies toward sinful habits. They have in front of them two models: the model of Adam's sinful actions and the model of grace in the life and teachings of Christ. Their unblemished will is able to follow any model without God's direct assistance or evil instigation. On the one hand, they sin freely and without internal necessity. On the other hand, they obey and follow the path of salvation by their own decision.

${ }^{11}$ Quest. V, in Works, 2:66. 
One question remains before finishing with Pelagius's teaching on free will and grace. According to Pelagius, do humans need the precedence of grace for salvation? I think the answer is yes, for although there is no necessity of prevenient grace as an internal healing power, there is a necessity of the anticipation of grace as an external model of life and perfection. For Pelagius, external examples of sinful habits stimulate the commission of sin in humans; likewise external grace in the preaching of the law and the life of Jesus excites the human will by exhortation, imitation, association, or example to accept salvation and follow these models of sinlessness of life. Thus, for Pelagius grace is indeed to some extent prevenient to human will, although an external version only. ${ }^{12}$

Pelagius's conclusions were abhorrent to Augustine. Augustine believed that due to original sin (which he described as a disease, a bondage or enslaving power, and a guilt), every human is born with a disposition to sin that is impossible to overcome by human power. While for Pelagius sin is a wicked act, a wrongful action, and human pride in contempt of God, ${ }^{13}$ for Augustine sin is a corruption or a malady within human nature. It is from this reality that humans, as a massa damnata [mass of damnation], become propagators and perpetrators of immorality. Because they are not able to liberate themselves, sin becomes an enslaving power that maintains individuals under continual bondage of concupiscence. ${ }^{14}$ The result is guilt, actual and original. Guilt is not just an

${ }^{12}$ See Ferguson, Pelagius, 170-175.

${ }^{13}$ Pelagius, On Nature, §17, 31-32.

${ }^{14}$ TeSelle, Augustine, 41. 
inner feeling of unworthiness or regret, but a legal/judicial state before God for willful participation and original co-responsibility in Adam's sin. ${ }^{15}$

From the beginning Augustine deconstructed Pelagius's teaching of an unblemished freedom of will. Unlike Pelagius, Augustine believed that humans are completely alienated from God, their will is perverted, and their liberty is compromised under slavery, servitude, and the necessity of sin. Augustine states that: "vanished by the sin into which it fell by its volition, nature has lost liberty." ${ }^{, 16}$ While the guilt acquired by original sin is easily removed by baptism, the actuality, slavery, and servitude of sin and the corruption-depravation of human free will is impossible to avoid without the special grace and intervention of God.

In such a miserable situation, for Augustine, grace cannot be restricted to external aid, as Pelagius had suggested, but is a mandatory inward work of the Spirit to overcome sin. ${ }^{17}$ Augustine exalts God's grace throughout his writings. The first action of God toward sinful humanity occurs through prevenient grace. Prevenient grace, according to Augustine, could be properly summarized in two main points:

${ }^{15}$ Augustine understood that Paul in Romans pointed to this reality explaining that the expression "in whom ..." means that in Adam "all sinned."

${ }^{16}$ Augustine, De perfection justiciae hominis 4.9, in Nicene and Post-Nicene Fathers (NPNF). ed. Philip Schaff, trans. P. Holmes and Robert E. Wallis, rev. Benjamin B. Warfield., vol. 5: Augustine: Anti-Pelagian Writings (New York: Christian Literature Company, 1887, reprint, 2012), 161.

${ }^{17}$ Augustine rejects Pelagius's assumption that imitation of Christ's example is sufficient to overcome human sinfulness. He states "it is not simply the imitation of His example which makes men just, but His grace which regenerates men by the Spirit," Augustine, De pecc. merit. et remiss 1.5.19, NPNF, 22. 
First, it is the anticipation of God's actions to rescue people from eternal perdition. Before any human movement toward God, says Augustine, God moves toward humans. In this manner, Augustine assures us that grace precedes human freedom of will. Thus, salvation begins by God's direct initiative. Explaining in one of his sermons the encounter of Zaccheus with Jesus, Augustine noted, "Zaccheus was seen, and saw; but unless he had been seen, he would not have seen. For 'whom He predestinated, them also He called.' In order that we may see, we are seen; that we may love, we are loved. 'My God, may His pity prevent me!"”18 Augustine points to the prevenient nature of God's grace elsewhere in his writings. God, he says, "anticipates us that we may be healed... he anticipates us that we may be called ... he anticipates us that we may lead godly lives ... because without Him we can do nothing (Psalm 59:10). ${ }^{, 19}$ Augustine discusses the precedence of God's grace to the will of humans in terms of operative [prevenient] grace (operante charitatem) and cooperative [subsequent] grace (cooperante charitatem). $\mathrm{He}$ speaks of God

who prepares the will, and perfects by his co-operation what He initiates by His operation[.] He works in us that we may have the will [prevenient grace], and in perfecting works with us when we have the will [subsequent grace]. He operates, therefore, without us, in order that we may will [prevenient grace]; but when we will, and so will that we may act, He co-operates with us. ${ }^{20}$

${ }^{18}$ Augustine, "Zacchaeus" Sermon 174, in "Sermons," The Works of Saint Augustine: A Translation for the 21st Century, trans. Edmund Hill and ed. John E. Rotelle (New Rocelle, NY: New City, 1992), 259-261.

${ }^{19}$ Augustine, De natura et gratia 35; NPNF, 133.

${ }^{20}$ Augustine, De gratia et libero arbitrio, 17.33; NPNF, 458. "Et quis istam etsi parvam dare coeperat charitatem, nisi ille qui praeparat voluntatem, et cooperator perficiens. Ut ergo velimus, sine nobis operator; cum autem volumus, et sic volumus ut 
Augustine's own struggles with sin and conversion show him the need for the prevenient and the always working grace of God. His Confessions witness to God's converting grace and anticipate Augustine's unwillingness and resistance to accept the call of salvation. B. B. Warfield summarizes Augustine's experience, pointing out that, "his own experiences in his long life of resistance to, and then of yielding to, the drawing of God's grace, gave him a clear apprehension of the great evangelic principle that God seeks men, not men God, such as no sophistry could cloud." ${ }^{21}$ Likewise, J. Patout Burns asserts that "the congruous vocation, as illustrated in Augustine's narrative of his own conversion, works upon an individual's prior disposition, thereby moving him to make the decision which God intends. ${ }^{, 22}$

Second, prevenient grace is a gracious gift of God. Augustine states that grace "is not rendered for any merits, but is given gratis, on account of which it is also called grace. ${ }^{, 23}$ Because grace is given gratis preceding any meritorious human actions, prevenient grace is anti-merit. ${ }^{24}$ Humans in their sinfulness and corruption, massa

faciamus, nobiscum cooperatur: tamen sine illo vel operante ut velimus, vel cooperante cum volumus, ad bona pietatis opera nihil valemus." NPNF, xxi.

${ }^{21}$ B. B. Warfield, "Introduction to Augustine's Anti-Pelagian Writings.” in

22 J. Patout Burns, The Development of Augustine's Doctrine of Operative Grace (Paris: Etudes Augustiniennes, 1980), 47. For more on Augustine's view on prevenient grace see, Moi Kieng Ting, Augustine's and Wesley's Concepts of Prevenient Grace: A Comparative Study (Saarbrücken, Germany: Lambert, 2010), 20-35.

${ }^{23}$ Augustine, De natura et gratia 3; NPNF, 122.

${ }^{24}$ Livia Bud says that Augustine always affirms the gratuity of grace in relation to both, human will and actions. She states: "Sant'Agostino affermava la gratuità della 
damnata, do not deserve God's grace and love (Romans 5:15), but solely condemnation and rejection. Consequently, grace could exclusively be granted by God's free decision, love, and mercy. ${ }^{25}$

After describing the preventive and free nature of prevenient grace, Augustine begins to discuss the mode of operation. Prevenient grace, he says, operates by the work of the Holy Sprit both internally/individually and externally by the Church. In this manner, prevenient grace is related to the illumination of the Holy Spirit in human beings sometimes by the preaching of the Scriptures and sometimes by internal callings to prepare their will for conversion and repentance. ${ }^{26}$

On the one hand, faithful to his neo-platonic commitments supported by his reading of the Bible, he states that grace is an inwardly healing substance that works

grazia in rapporto con le azioni (usando il testo di Paolo, dove si afferma leimpossibilità di agire conformemente alla buona volontà). In tutti i passaggi fino qui troviamo questa menzione, che la grazia viene concessa senza nessun merito anteriore delle azioni, da questo punto in poi, però, lui affermerà la gratuità anche in rapporto con la volontà. Affermerà in maniera insistente la gratuità in relazione ad ogni tipo di merito. E questo nel senso della citazione delle parole di San Paolo: "Che cosa mai possiedi che tu non abbia ricevuto?" Livia Bud, "Sant'Agostino e il rapporto tra libero arbitrio e grazia" Scientific Journal of Humanistic Studies 3, no. 4 (2011): 25.

${ }^{25}$ See Creswell, Augustine's Dilemma, 71; Anthony Dupont, Gratia in Augustine's Sermones ad Populorum During the Pelagian Controversy (Leiden, the Netherlands: Brill, 2013), 76.

${ }^{26}$ Eleuterio Elorduy describes the grace of conversion in Augustine in this manner: "La teoría de la iluminación comunicada por Dios a la inteligencia humana, unas veces en forma de predicación, otras veces en llamamientos internos, es una prueba manifiesta del congruismo natural y sobrenatural empleado en la economía de la gracia que abarca tanto el orden moral como el de la vida inmanente del alma." Eleuterio Elorduy, "San Augustín y Suárez: El doctor de la gracia," Augustinus 16 (1971): 34. 
within individual humans' hearts. ${ }^{27}$ He states in his treatise On Forgiveness of Sins and Baptism that "our turning to God is not possible, except He rouses and helps us." ${ }^{28}$ A human person, says Augustine, receive[s] "the Holy Ghost, by whom there is formed in his mind a delight in, and a love of . . God. The free gift, he may conceive an ardent desire to cleave to his Maker, and may burn to enter upon the participation in that true light. Now, in order that such a course may engage our affections, God's 'love is shed abroad in our hearts' . . . through the Holy Ghost, which is given to us." 29

On the other hand, mainly using the Scriptures, Augustine also pointed to the external nature of grace. Grace as an external influence resonates, convinces, and draws humans to God's offer of salvation. According to Augustine, external incentives on human perceptions will work by "evangelical exhortation" of the Church and "the commands of the law." ${ }^{30}$ Then, the preaching of the Word and the Law rebukes humans of their frailties and advises them of their necessity of God's grace. ${ }^{31}$ This is important

${ }^{27}$ According to J. Patout Burns, Augustine accepted the Plotinian concept of grace as an inward and dwelling influence within the human soul because he also found sufficient evidence in the Scriptures to support it. He frequently quoted in support Romans 5:5 and 1 John 4:7, 17 to evidence the concept of grace as an inward healing power working within the human soul. See Burns, "Grace" in Augustine Through the Ages: An Encyclopedia, Allan D. Fitzgerald, ed. (Grand Rapids, MI: Eerdmans, 1999), 392.

${ }^{28}$ Augustine, De peccatorum meritis et remissione, et de baptismo parvulorum, 2.31, NPNF, 56 .

${ }^{29}$ Augustine, De spir. et litt. 3.5; NPNF, 84-85.

${ }^{30}$ Augustine, De spir. et litt, 34.60; NPNF, 110.

31 Ibid. 
because at this point Augustine concurs with Pelagius that the preaching of the Gospel and the commandment of the law have a role as external means of prevenient grace to make humans willing to believe. However, unlike Pelagius, Augustine strongly refuses to limit grace to these external aids. Grace is primordial to any human actions because God "in all things prevents [precedes] us with His mercy.",32

Prevenient grace results in a series of spiritual effects that lead humans to salvation. Prevenient grace liberates, empowers, and heals human freedom of will. Augustine assures that "by grace the healing of the soul from the disease of $\sin ^{\text {"33 }}$ and the "cure of the will" occurs, resulting in the establishment of the freedom of will. ${ }^{34}$ So, for Augustine, freedom of will is clearly not the result of nature, but the result of grace. Despite the corruption of the human will, prevenient grace gives humans a new supernatural predisposition that prompts the will before an individual ever wills. Then, grace frees, heals, and enables human free will, not only enlarging a person's area of choice but by substituting the evil desires with a system of good choices. God's omnipotent will and operating grace is not irresistible, but congruous and effectual. ${ }^{35}$ God knows beforehand that the "human will" will freely consent to what He proposes for it, and He sets everything to accord with that.

${ }^{32}$ Augustine, De spir. et litt, 34.60; NPNF, 110.

${ }^{33}$ Augustine, De spir. et litt. 30.52, NPNF, 106.

${ }^{34}$ Ibid.

${ }^{35}$ TeSelle, Augustine, 43-44; John M. Rist, Augustine: Ancient Thought Baptized (New York: Cambridge University Press, 1994), 133. 
Another important spiritual effect of prevenient grace is faith. According to Augustine, prevenient grace moves human freedom of will toward faith. Because grace has already liberated free will, it is now able to exercise faith. Faith, like free will, for Augustine is therefore a gift of grace. God's prevenient grace is the indispensable key that enables depraved persons to become spiritually alive again and believe in God. Augustine states that "by faith [comes] the acquisition of grace against sin, by grace the healing of the soul from the disease of sin, by the health of the soul freedom of will, by free will the love of righteousness." ${ }^{36}$ Although faith is the source of grace and it is "in our own power," ${ }^{37}$ Augustine scripturally clarifies that "there is no power but comes from God (Rom 13:1)." Then, everywhere in his writing, Augustine emphasizes that faith is rightly regarded as a gift of grace. Quoting two passages of Paul in 2 Timothy 4:7 and 1 Corinthians 7:25, Augustine concludes that "even faith itself cannot be had without God's mercy, and that it is the gift of God.",38

\section{Prevenient Grace in the Theology of the Medieval Church}

An informed overview of the concept of prevenient grace in the theological development of the Medieval church is necessary to show how the Augustinian doctrine of prevenient grace was inherited, used, and synthetized by the Medieval theologians. In

${ }^{36}$ Augustine, De spir. et litt. 30.52; NPNF, 106.

${ }^{37}$ Ibid., De spir. et litt. 54; NPNF, 107.

${ }^{38}$ Augustine, De gratia et libero arbitrio 17,7, NPNF, 450. See also "The spirit of grace, therefore, causes us to have faith," 28.14 . 
this section, I consider the contributions to the conceptualization of the doctrine of prevenient grace from the Second Council of Orange to the Council of Trent. Attention to the conciliar documents is important because they better show how the medieval church as a whole viewed the concept of prevenient grace in their soteriological constructions rather than the opinion of particular theologians. Nevertheless, I also consider the contributions of important medieval theologians like Peter Lombard, Thomas Aquinas, Gabriel Biel, and some contemporaries of Arminius like Louis de Molina.

Prevenient Grace after the Pelagian Controversy:

The Second Council of Orange

It seems important first to consider at least briefly the controversy about grace and free will around the Pelagian controversy after Augustine. Specifically I would like to pay attention to the Second Council of Orange (529 AD) that used the concept of prevenient grace to counteract the teaching of John Cassian (360-435 AD). Jaroslav Pelikan argues that the reaction of Cassian and his followers against Augustine resulted because they perceived that Augustine's theology "glorified grace by belittling nature and free will” destroying human "responsibility." "39 Consequently, Cassian's main intention was not to destroy grace, but to defend a proper role in salvation for the freedom of human will.

Adolph Harnack claims that Cassian completely supports God's grace as "the foundation" of human salvation. Cassian believes that "grace is absolutely necessary in

39 Jaroslav Pelikan, The Christian Tradition: A History of the Development of Doctrine, vol. 1, The Emergence of the Catholic Tradition 100-600 (Chicago, IL: The University of Chicago Press, 1971), 320. 
order to reach final salvation," 40 because without "God's help . . . human weakness cannot accomplish anything that has to do with salvation." ${ }^{41}$ However, when Cassian comes to consider the beginning of faith, grace is overshadowed by the will of man. Harnack summarizes Cassian's view explaining, "the beginnings of the good resolves, good thoughts, and faith — understood as the preparation of grace — can be due to ourselves." 42

As a result, grace is not critical at the beginning of salvation. For Cassian, therefore, the initial movement toward faith should be found within the human free will before grace pours into the human soul. For Cassian, indubitably, "Adam and Eve's fall had entailed corruption and inevitable sinfulness on the whole race. But with a free, though a weakened, will, there also remained a certain ability to turn to the good." ${ }^{43}$ Cassian refused to endanger in any sense the ability of human will to seek God and perform what is spiritually and morally good.

However, in his exposition on 1 Tim 2:4, and similar passages like Mt 18:14, 2 Sam 14:14, Ezek 33:11, and Mt 11:28, Cassian came close to an understanding of

${ }^{40}$ Adolph Harnack, History of Dogma, (Boston, MA: Little, Brown, and Company, 1899), 5:247.

${ }^{41}$ John Cassian, "The Conferences of John Cassian," in Sulpitius Severus, Vincent of Lérins, John Cassian, ed. P. Schaff and H. Wace; trans. E. C. S. Gibson, vol. 11 (New York: Christian Literature Company, 1894), 424.

${ }^{42}$ Harnack, History of Dogma, 5:247. For further exposition of Cassian's doctrine of grace see, Owen Chadwick, John Cassian (New York: Cambridge University Press, 1968), 110-136.

${ }^{43}$ Harnack, History of Dogma, 5:248. 
prevenient grace. He stated that when God's "goodness sees in us even the very smallest spark of good will shining forth, which he himself has struck as it were out of the hard flints of our hearts, he fans and fosters it, stirs it up, and nurses it with His breath. ${ }^{, 44} \mathrm{He}$ further explains that "when [God] sees in us some beginning of good will," he immediately "enlightens it and strengthens it and urges it on towards salvation, increasing that which He Himself implanted or which He sees to have arisen from our own efforts. ${ }^{, 45}$ Even more precise is his remark in his thirteenth polemical Conference in which he describes the necessary balancing of the farmer's work and the rain to produce a copious harvest:

From which we clearly infer that the initiative (initia) not only of our actions but also of good thoughts comes from God (ex deo esse principium), who inspires us with a good will to begin with, and supplies us with the opportunity of carrying out what we rightly desire: for 'every good gift and every perfect gift cometh down from above, from the Father of lights,' (James 1:17) who both begins what is good, and continues it and completes it in us, as the Apostle says: 'But He who giveth seed to the sower will both provide bread to eat and will multiply your seed and make the fruits of your righteousness to increase.' (2 Cor 9:10) But it is for us, humbly to follow day by day the grace of God (gratiam dei) which is drawing (adtrahentem nos) us. ${ }^{46}$

Obviously, these passages show the preeminent role that Cassian attributed to God's grace. A concept of prevenient grace in Cassian's theology could be defended using these pieces of his writings. However, a better understanding of Cassian's whole argument in his Conferences seems to indicate that he did not necessarily defend a

${ }^{44}$ Cassian, "The Conferences," 425.

${ }^{45}$ Ibid., 426.

${ }^{46}$ Cassian, Conferences 2.13.3. See Corpus Scriptorum Ecclesiasticorum Latinorum, Iohannis Cassiani Opera, vol. 24 (Vindabonae: Apvd C. Geroldi Filium Bibliopolam Academiae, 1886), 363-364. 
preeminence of grace over the human free will role in salvation, but a balanced view that notes the necessity of grace in every human effort for salvation. ${ }^{47}$ Grace, for Cassian, therefore, is not prevenient, anticipating human freedom of will, neither is grace always preceded by human good will, but it is more properly coexistent with freedom of will. ${ }^{48}$

${ }^{47}$ Rebecca Harder Weaver argues that "Cassian has unequivocally stated the case for the necessity of grace from beginning to end of the process of salvation." His main interest "was to maintain both grace and the freedom of will," Divine Grace and Human Agency: A Study of the Semi-Pelagian Controversy (Macon, GA: Mercer University Press, 1996), 111-112. Similarly, A. M. C. Casiday writes that Cassian "baldly asserts that God's grace, not human free will, is responsible for 'everything which pertains to salvation-even faith," Tradition and Theology in St John Cassian (New York: Oxford University Press, 2007), 102-103.

${ }^{48}$ Reinhold Seeberg, Text-Book of the History of Doctrines (Grand Rapids, MI: Baker, 1952), 1:369. See Cassian, Conferences 2.13.11, 12, 13. See also Weaver, Divine Grace and Human Agency, 112; Chadwick, The Church in Ancient Society, 114-116. The synergistic nature of the relation of grace and free will from the beginning to the end of salvation in Cassian's theology is most properly understood in the context of Chadwick's suggestion that for Cassian the human experience after the fall is not a state of total depravity and original sin demanding the action of a preparatory grace in order to accept God's offer of salvation, but instead is a continual "strife between flesh and spirit," 114 . Boniface Ramsey interprets Cassian slightly differently. He argues that Cassian by the end of his work completely dissolves the relationship between grace and free will that he previously had defended in a more balanced way. Ramsey suggests that this is the result first of the tradition to which Cassian is appealing, Church fathers like Athanasius and Basil, "in which grace was often not prominently or even explicitly discussed," and second, of his monastic ideals that looked to the prominence of grace in Augustine's theology as detrimental to the role of human effort in salvation. It seems to me that in Ramsey's opinion the only logical conclusion from Cassian's writings is that free will always precedes the gift of grace. I think that such a conclusion is true for some of Cassian followers, but if we take into account all of Cassian's writings we recognize that he worked strenuously to maintain a synergistic view of free will and grace from the beginning to the end of the work of divine redemption. See Boniface Ramsey, "John Cassian and Augustine," in Grace for Grace: The Debates after Augustine and Pelagius, ed. Alexander Y. Hwang, Brian J. Matz, and Augustine Casiday (Washington, D.C.: The Catholic University of America Press, 2014), 129-130. 
Although Cassian and his followers gave more attention to the role of grace in salvation than Pelagius, unfortunately they nonetheless failed to conceptualize clearly in their theology of salvation the concept of prevenient grace. Perhaps Faustus of Riez, Cassian's follower and most distinguished theological defender, makes clear such a failure, emphatically asserting in his treatise De gratia that "God awaits the human will, so that there may be an equitable reward in the case of willing. ${ }^{, 49}$ It is this view that centuries later was labeled as semi-Pelagianism, because it defends a soteriology in which the beginning of faith arises first from the powers and abilities of individuals, with God's grace only subsequently rewarding such individual willing.

It is mainly in response to this view that the Second Council of Orange (529 AD) emphasized the role of prevenient grace in the onset of faith. Ralph W. Mathisen writes that even the doctrines of sin and human freedom of will were discussed only as "they related to prevenient grace. ${ }^{, 50}$ The seventh and eighth capitula of the council cursed any teaching that supported the view that "through the vigor of nature, without inspiration of the Holy Spirit, it was possible to think or choose anything related to salvation or to be saved," and "that some could gain grace ... through free will." ${ }^{51}$ The anathematization of

${ }^{49}$ Faustus of Riez, De gratia, 1.18; 2.12.

${ }^{50}$ Ralph W. Mathisen, "Caesarius of Arles, Prevenient Grace, and the Second Council of Orange," in Grace for Grace: The Debates after Augustine and Pelagious, ed. Alexander Y. Hwang, Brian J. Matz, and Augustine Casiday (Washington, D.C.: The Catholic University of America Press, 2014), 215.

${ }^{51}$ The summaries of the Council of Orange articles have been taken from Mathisen, 214-219. These articles are quoted in Mathisen, 214. I here provide the full quotation from the original Latin documents of the Council: (7) "Si quis per naturae uigorem bonum aliquid, quo ad salutem pertinit uitae aeternae, cogitare, ut expedit, aut 
these teachings that elevated nature and free will over God's preceding grace opened the way to strong affirmative statements in favor of a proper view of the reception of divine grace.

Most of the conciliar statements relate to prevenient grace, but capitula 14, 20, and 23 deserve our special attention:

(14) "No one who is miserable is freed from any misery except for one who is anticipated by the mercy of God (misericordia praevenitur)."

(20) "Man is capable of nothing good without God."

(23) "When they do what they wish in accordance with divine will, even if they do what they do willingly, nevertheless it is [because] the will of Him by whom what they wish is prepared and commanded [by God's prevenient grace]. ${ }^{, 52}$

elegire siue salutari, id est euangelicae, praedicationi consentire posse confirmat absque inluminatione et inspiratione Spiritus sancti, quit dat omnibus suautatem in consentiendo et credendo ueritati, heretico fallitur spiritu, non intellegens uocem Dei in euangelio dicentes: Sine me nihil potestes facire (Ioh 15:5), et illud apostoli: Non quod idonei sumus cogitare aliquid a nobis quiasi ex nobis, sed sufficientia nostra ex Deo est (II Cor 3:5)." and (8) "Si quis alius misericordia, alios uero per liberum arbitrium, quod in omnibus, qui de praeuaricationem primi hominis nati sunt, constat esse uisiatum, ad gratiam baptismi posse uenire contendit, a recta fide probatur alienus. His enim non omnium liberum arbitrium per peccatum primi hominis adserit infirmatum aut certe ita laesum putat, ut tamen quidam ualeant sine reuelatione Dei mysterium salutis aeternae per semit ipsos posse conquirere. Quod quam sit contrarium, ipse Dominus probat, qui non aliquos, sed neminem ad se posse uenire testator, nisi quem Pater adtraxerit, sicut et Petro dixit: Beatus es, Simon Bariona, quia caro et sanguis non revelauit tibi, sed Pater meus, qui in caelis est (Matt 16:17); et apostulus: Nemo potest dicere Dominum Iesum nisi in Spiritu sancto." in Caroli de Clerq, Corpus christianorum, Series Latina, Concilia Galliae, A. 511-A. 695, vol. 148A (Tvrnholti: Typographi Brepols Editores Pontificii, 1963), 57-58.

${ }^{52}$ Quoted in Mathisen, "Caesarius of Arles," 215-216. See the Latin text:

(14) "Nullus miser de quantacumque miseria liberator, nisi qui Dei misericordia 
The Council firmly supported the concept of prevenient grace and insisted that the beginning of salvation is impossible without the direct intervention of God's mercy and the work of the Holy Spirit. Interestingly, Mathisen argues that the Council claimed to gain support from the "ancient father"; however, an analysis of the documents demonstrates that they instead firmly grounded their conclusions on prevenient grace on Scriptural authority. ${ }^{53}$ For the Council, the Holy Scripture teaches the anticipation of God's grace to human will in passages like Psalm 78:8; 58:11.

In addition, the Council also stressed the gratuity of grace, quoting scriptural passages like Galatians 2:21 and Ephesians 4:8. Because prevenient grace anticipates human responses, logically it has to be gratis, a gift. Capitula 16 affirms that "no one should glory in what he seems to have as if he had not been given it," and capitula 25 remarks that "to love God is completely a gift of God." ${ }^{, 54}$ In this respect the Council decisively allied itself with Augustine's stance on the free nature of grace. In connection

praeuenitur, sicut dicit psalmista: Cito anticepit nos misericordia tua, Domine (Ps 78:8), et illud: Deus meus, misericordia eius praeueniet me (Ps 58:11)."

(20) "Nihil boni hominem posse sine Deu. Multa Deus facit in homina bona, quae non facit homo, nulla uero facit homo bona, quae non Deus praestat, ut faciat homo."

(23) "De uolumtate Dei et hominis. Suam uolumtatem homines faciunt, non Dei, quando id agunt, quod Deo displacit; quando autem ita faciunt, quod uolunt, ut diuinae seruiant uolumtati, quamuis uolentes agant, quod agunt, illius tamen uolumtas est, a quo et praeparatur et iubetur, quod uolunt," CCL 148A, 59-61.

${ }^{53}$ Mathisen, "Caesarius of Arles," 216-217.

${ }^{54}$ Quoted in Mathisen, "Caesarius of Arles," 216. See "Prosus donum Dei est diligere Deum," CCL 148A, 62. 
with this the Council made clear the unique and indispensable role of grace in salvation, strongly affirming that, "no one can be saved except through the mercy of God."

A final implication may be drawn from the passages of the conciliar documents.

The Council closely related baptism with the reception of grace and the liberation of the will. ${ }^{56}$ In this manner, the Council advocated in favor of an ecclesiological operation of prevenient grace. In their teaching on the freedom of the will, the Council affirmed the corruption and inability of the will to save itself, the anticipation of grace, and the role of baptism in restoring human free will. In the Definitio fidei the council states: "Because of the sin of the first man, free will has been so damaged and weakened that no one afterward can either love God as is fitting or believe in God or do for the sake of God that which is good, unless grace and divine mercy has anticipated him.. ${ }^{57}$ Then the Council comes to affirm the central role of baptism expressing that "this grace [prevenient grace] is not embodied in the free will of all who desire to be baptized, but is granted by the generosity of Christ" and "has been received through baptism.. ${ }^{, 58}$ Similarly, the Council

${ }^{55}$ Quoted in Mathisen, "Caesarius of Arles," 216. See "Neminem nisi deo miserante salvari," CCL, 148A, 60.

${ }^{56}$ Mathisen, "Caesarius of Arles," 218.

${ }^{57}$ Quoted in Mathisen, “Caesarius of Arles," 217: "Quod per peccatum primi hominis ita inclinatum et adtinuatum fuerit liberum arbitrium, ut nullus postea aut diligere Deum sicut aportuit aut credere in Deum aut operari propter Deum quod bonum est possit, nisi eum gratia misericordiae diuinae praeuenerit," CCL 148A, 62.

${ }^{58}$ Ibid. "Quam gratiam etiam post aduentum Domini omnibus, qui baptiszari disiderant, non in libero arbitrio habere, sed Christi nouimus simul et credimus largitate conferri," CCL, 148A, 62. 
in capitula 13 affirms, "the free will lost in the first man cannot be restored except through the grace of baptism." 59

One could speculate that this operation of prevenient grace in order to restore free will through the sacrament of baptism is restricted to infants because if baptism is the means to obtain the prevenient grace of God, then how and who or what draws unbelievers to the sacrament? The Council responds by clarifying that at least in believer's baptism God also anticipates human willingness to do what is right—in this case to accept the church's mediation of the sacrament of baptism. The Council of Orange states that in every case, even when the good impulse of the human heart prompts a person to devotedly seek baptism devotedly, it is God who "first inspires both our faith and our love for him. ${ }^{.60}$

\section{The Medieval Theologians and the Council of Trent}

Medieval theologians felt the necessity to balance theological ideas present in Augustine's writings. In Augustine, we encounter both a high view of grace and a high view of sin. As we have seen, for Augustine, humans after the fall are characterized by sinfulness; indeed, they are not able not to sin (non posse non peccare). He found the solution to this depravity in the sovereign prevenient grace of God, which irresistibly overcomes human infirmities. By introducing the concept of prevenient grace in his

${ }^{59}$ Quoted in Mathisen, "Caesarius of Arles," 215.

${ }^{60}$ Quoted in Mathisen, "Caesarius of Arles," 218: “et fidem et amorem sui prius inspirat," CCL 148A, 63. 
controversy against Pelagius, Augustine set the trajectory for the use of this idea in the discussion on free will and God's grace for the future generations.

Peter Lombard (c. 1096-1160) asserts that the loss of the freedom of will is the most serious effect of Adam's original sin. ${ }^{61}$ The solution to this problem, Lombard recognizes, is God's prevenient grace that enables human free will. In book 2, distinction 27 of his Sentences, Lombard says, "And that prevenient grace, which is also a virtue, is not the use of free choice, but rather the good use of free choice comes from it. It is ours from God, not from ourselves." 62 According to Lombard, by this prevenient grace "the will of man is bathed so as to germinate and produce fruit, that is, it is healed and prepared to will the good, according to which the grace is called operating .... and [this] grace is not unsuitably termed 'virtue,' because it heals and aids the infirm will of man." ${ }^{63}$ Then, Lombard makes prevenient grace necessary and precedent to the voluntary act of human will.

Fesko believes that Lombard defends a creational view of prevenient grace. He seems to argue that for Lombard prevenient grace is a providential and natural faculty

${ }^{61}$ See Marcia L. Colish, "Peter Lombard," in The Medieval Theologians: An Introduction to Theology in the Medieval Period, ed. G. R. Evans (Malden, MA: Blackwell, 2001), 175.

${ }^{62}$ See Dist. XXVII.7, in Peter Lombard, The Sentences, vol. 2, On Creation, trans. Guilio Silano, (Toronto: PIMS, 2008), 136.

${ }^{63}$ Dist. XXVII.2, in Sentences: On Creation, 133. For Lombard operating grace is also a term to refer to prevenient grace. For him, by prevenient grace "the will of man is freed and prepared to will the good," see Dist.XXVI.8, in Sentences: On Creation, 130. 
with which God created human beings. ${ }^{64}$ However, it is important to note that Lombard links prevenient grace with virtue. ${ }^{65}$ Virtue, for Lombard, is an uncreated habit of the soul infused by the indwelling of the Holy Spirit. Analyzing Lombard's question on the source of salvific love, Steven Ozment concludes that for Lombard human beings are "saved by an uncreated, not created habit, by uncreated, not created, love, by the Holy Spirit within, not an acquired talent he can call his own." ${ }^{, 66}$ Likewise, Lombard believed in an uncreated, not created prevenient grace. It is the infused working of the Holy Spirit in the soul. Lombard's emphasis on the indwelling of the Holy Spirit in the salvific working of prevenient grace and love in some ways sets the Protestant trajectory for this concept in contrast with the majority of medieval scholastic voices. Ozment says that Luther sided with Lombard ${ }^{67}$ and, as we will see, Arminius also had a strong emphasis on an uncreated prevenient grace as the internal work of the Holy Spirit in the human soul.

Thomas Aquinas (c. 1225-1274) was reluctant to assume entirely the Augustinian idea of total depravity. Using Bede's interpretation of the parable of the Good Samaritan, he assumed that not all man's powers were destroyed by the sin of Adam. For Aquinas the principal consequence of original sin was a usurpation of powers where the "lower

${ }^{64}$ Fesko, “Arminius on Facientibus,” 357-358.

${ }^{65}$ See Dist. XXVII.7, in Sentences: On Creation, 136.

${ }^{66}$ Stephen Ozment, The Age of Reform, 1250-1550: An Intellectual and Religious History of Late Medieval and Reformation Europe (New Haven, CT: Yale University Press, 1981), 31.

${ }^{67}$ Ozment, The Age of Reform, 31. 
powers" usurped the good of nature. ${ }^{68}$ As a result "all the powers of the soul are left, as it were, destitute of their proper order, whereby they are naturally directed to virtue; which destitution is called wounding of nature." ${ }^{69}$ Therefore, for Aquinas human nature is evidently damaged and wounded but not totally corrupted. Therefore, Aquinas's view of the effects of sin on human nature should be described more in terms of weaknesses or fragilities than in terms of total corruption.

Gregg R. Allison claims that for Aquinas "the greatest disruption that sin caused in people is their loss of orientation toward seeking God as their greatest goal." $" 70$ Aquinas continually stated that humans could not turn from sin to God using only their own capacities. ${ }^{71}$ He quoted John 15:5, "without Me, you can do nothing," to demonstrate that reality as an essential Christian truth. ${ }^{72}$ However, this does not mean that humans do not

68 "The natural inclination to virtue, finally, is diminished by sin. Actions generate an inclination to similar actions, as we said in Q. 51, Art. 2, and the inclination to one of two contraries is bound to be diminished by an inclination to the other. Now sin is the contrary of virtue. The good of nature which consists in the inclination to virtue is therefore bound to be diminished by the very fact that a man sins." $1.2 .85 .1,1: 967$. For Aquinas the lower powers represent among others the free will or the power of choice of humans. The "good of nature" represents human reason or intellect.

${ }^{69}$ Ibid. "Therefore in so far as the reason is deprived of its order to the true, there is a wound of ignorance; in so far as the will is deprived of its order to the good, there is a wound of malice; in so far as the irascible is deprived of its order to the arduous, there is a wound of weakness; and in so far as the concupiscible is deprived of its order to the delectable, moderated by reason, there is a wound of concupiscence."

${ }^{70}$ Gregg R. Allison, Historical Theology: An Introduction to Christian Doctrine (Grand Rapids, MI: Zondervan, 2011), 352.

${ }^{71}$ Thomas Aquinas, Summa Theologica $(S T)$. trans. Fathers of the English Dominican Province, (New York: Benzinger Brothers, 1947), 1.2.109.1-10.

${ }^{72}$ Ibid., 1.2.109.8. 
have the power to turn to God, but that their powers are so weak that they need an external help-the grace of God. ${ }^{73}$

Aquinas calls this enabling grace habitual or prevenient grace. But before considering the operation and nature of prevenient grace in Aquinas, it is important to highlight that he does not accept an ontological division of divine grace. Aquinas only affirms a proper division regarding its effects. ${ }^{74}$ Then, what is said about prevenient grace is also applicable to all effects of grace in his writing; that is to co-operating or subsequent grace.

Thus for Aquinas, prevenient grace "moves the soul inwardly or inspires the good wish." 75 Without this grace humans by themselves cannot know salvific truth, do any good, love God above all things, fulfill the moral commandments of the law, and deserve eternal life. ${ }^{76}$ Aquinas clearly stated that the "preparation of the will" for

73 Thomas P. Harmon, "The Sacramental Consummation of the Moral Life According to St. Thomas Aquinas," New Blackfriars 91, no. 1034 (2010): 466.

${ }^{74} S T, 1.2 .11 .2-3 ; 1: 1137-1338$. In Aquinas' exposition on these effects of grace, these effects continually interchange within them. For instance, the effect of the grace that heals the soul is prevenient in relation with the second effect "to desire good." But, the effect "to desire good" although subsequent in relation with the first, it is prevenient in relation with its posterior, the third effect of grace "to carry into effect the good proposed." This Augustinian emphasis could be also found in his assertion that "grace, inasmuch as it causes the first effect in us, is called prevenient with respect to the second, and inasmuch as it causes the second, it is called subsequent with respect to the first effect," $S T, 1.2 .111 .3$.

${ }^{75}$ ST, 1.2.109.6.

${ }^{76} S T, 1.2 .109 .1-5$. 
salvation "cannot take place without the habitual gift of grace." $" 77$ This grace is a divine infusion working within human nature in order to heal human infirmities and corruptions. ${ }^{78}$ Mark Ellingsen affirms that for Aquinas and other Scholastic theologians infused grace is "a kind of substance in the faithful,",79 which moves the corrupted will of humans toward God. According to Aquinas, this infused grace of God is a gratuitous gift and not a virtue, merit, or a power naturally present in the soul. ${ }^{80}$ Quoting Psalm 83:12, Aquinas emphasizes that grace is a gift that "surpasses every capability of created nature." 81

However, we should understand the operation of prevenient grace in Aquinas's theology within the context of his Aristotelian philosophy. In this discussion, two aspects of Aristotle's philosophy are central for Aquinas. First, for Aquinas, although the ultimate source of grace is divine, grace as an infused medicine "is in the soul as a reality

${ }^{77}$ ST, 1.2.109.6.

${ }^{78}$ Aquinas divided his Treatise on Grace into six great parts with six questions on (1) the necessity of Grace, (2) the definitions of the grace of God, (3) the division of grace, (4) the cause of grace, (5) the effects of grace, and (6) the necessity of merits (see 1.2.109-114). Aidan Nichols describes grace in Aquinas' writings as a “divine energeia enabling the creature not only to perceive (as revelation) but to do (as salvific relevant action) what of itself it could neither do nor perceive," Discovering Aquinas: An

Introduction to His Life, Work, and Influence (Grand Rapids, MI: Eermans, 2002), 105.

${ }^{79}$ Mark Ellingsen, Reclaiming Our Roots: Martin Luther to Martin Luther King (Harrisburg, PA: Trinity, 1999), 36.

${ }^{80} S T, 1.1 .110 .2-4$.

${ }^{81} S T, 1.2 .112 .1$. 
connatural to man." ${ }^{\prime 82}$ This means that habitual or prevenient grace is a natural endowment in human beings. However, this natural gift should not be confused with a substantial or intrinsic reality. Rather, grace is an accidental reality in the soul. Aquinas says, "every substance is either the nature of the thing whereof it is the substance or is a part of the nature, even as matter and form are called substance. And because grace is above human nature, it cannot be a substance or a substantial form, but is an accidental form of the soul. ${ }^{, 83}$ Then, humans by habitually using the accidental existence of prevenient grace in their soul are capable of voluntarily becoming spiritual beings.

Second, Aquinas in his Treatise On Grace continually emphasized the role of God as the prime mover and the initial and unique cause of grace. He is now appealing to Aristotelian causality. According to Eric Luijten, Aquinas's view of motion implies three principal elements: "the motion of the one who moves, the motion of the one who is moved, and the completion of the motion: the arrival at its end. ${ }^{184}$ As a result, for Aquinas, God "the absolutely primary mover" $" 85$ moves the will of humans, then the will of humans moves along with God, and finally God completes the motion with the forgiveness of sin and the justification of the sinner. In this case, grace is always present, but humans need to exercise the gift of grace continually.

${ }^{82}$ Ozment, The Age of Reform, 32.

${ }^{83} S T, 1.2 .110 .2$.

${ }^{84}$ Eric Luijten, Sacramental Forgiveness as a Gift of God: Thomas Aquinas on the Sacrament of Penance (Utrecht, the Netherlands: Peeters Leuven, 2003), 75

${ }^{85} S T, 1.2 .109 .6$. 
In this manner, the effects of prevenient grace are to move the will of humans to God and to heal human infirmities. These effects of prevenient grace return the human faculties to their proper and original state making it possible to choose God, His offer of salvation, and perform Christian virtues. Through this divine cooperation humans may attain perfection, desiring the good, carrying into effect good works, persevering in the faith, and finally reaching celestial glory ${ }^{86}$ It is in the exercising of this connatural prevenient grace that humans will cooperate with God and consequently they can call their good works a merit of their own. Stephen Ozment clearly resumes Aquinas's teaching in this aspect: "With the infusion of supernatural grace an individual receives the essential foundation, an initial disposition, basic instruction, as it were, in how to order his life in obedience to God. He must still exercise the grace he has received in order to become "expert" in the art of loving God and man."

In summary, prevenient grace produces the first spiritual effects and turning toward God in humans in the process of salvation. For Aquinas, God's prevenient grace as a connatural infusion in the human soul moves and heals the will in order to overcome the infirmities introduced by sin. It follows that human beings, exercising and using freely their freedom of will, cooperate with the grace of God. Thus, Aquinas accomplished the difficult theological task of maintaining the primordial role of God's grace in salvation while at the same time preserving the necessity of human willing reception of God's offer of salvation.

${ }^{86} S T, 1.2 .109 .6$.

${ }^{87}$ Ozment, The Age of Reform, 32-33. 
Gabriel Biel (1420-1495) conveyed Aquinas's conclusion on a connatural prevenient grace to its logical implications. For Biel, although it is a free divine gift, prevenient grace is a natural endowment of the human soul. This providential prevenient grace erodes the consequences of original sin. This natural endowment is universally present in the human soul correcting the infirmities of the will. Humans, therefore, enjoy an undamaged freedom of will capable of spiritual and moral good, prepare themselves for further reception of grace, and obey God's commandments. ${ }^{88}$ This prevenient grace, however, is not sufficient for achieving ultimate salvation, but only to prepare for faith and demonstrate worthiness of receiving further assistance from God. For this strongly synergistic view of salvation, Biel became the target of Protestant reformers like Calvin and Luther, especially against his [in]famous axiom: Facientibus quod in se est Deus non denegat gratiam. This means that humans, for Biel, could attain salvation by a congruous working of grace and free will. The greatest problem with Biel's conceptualization of prevenient grace or love is that although it is not "a human task insofar as it is God alone who can infuse it in us; but we are responsible for the preparation and the later preservation" of salvific grace and love. ${ }^{89}$ Arminius, we will see, like Luther will disprove Biel's conclusions of a natural prevenient grace as well as a human preparation for grace.

${ }^{88}$ See Gregory Graybill, Evangelical Free Will: Phillip Melanchthon's Doctrinal Journey On the Origins of Faith (New York: Oxford University Press, 2010), 41.

${ }^{89}$ Heiko A. Oberman, Dawn of the Reformation (Grand Rapids, MI: Eerdmans, 1992), 114. 
Finally, it is vital to pay attention to an important figure who just preceded Arminius's time, Louis de Molina (1535-1600), who is one of the medieval theologians that most extensively used the concept of prevenient grace in his writings. He paid attention to the concept of prevenient grace because of the preeminent consideration that the Council of Trent gave to this idea. At this point, it seems useful to consider briefly the discussions of Trent before paying attention to Molina's conceptualization of prevenient grace.

The Council of Trent (Concilium Tridentinum), after decades of open opposition, negotiations, political struggles, and war, finally met in its first session on December 13, 1545. ${ }^{90}$ During the theological discussions, the conciliar fathers focused on answering objections, mainly on Scripture and soteriology, raised by the Reformers. The concept of justification proved to be challenging for the theologians in the Council, because there were among the participants sympathizers of Luther's forensic views on justification. ${ }^{91}$ Such sympathizers wanted to hold the Catholic traditional view on the role of human and meritorious works in salvation while at the same time integrate some of Luther's teachings. Thus, it is not surprising that the Council returned to the Augustinian concept

${ }^{90}$ A. G. Dickens, The Counter Reformation (Harcourt, Brace and World, 1969), 107-108; John W. O'Malley, Trent: What Happened at the Council (Cambridge, MA: Harvard University Press, 2013), 49-76; Guiseppe Alberigo, "Trent, Council of" in The Oxford Encyclopedia of the Reformation, Hans J. Hillerbrand, ed. (Oxford, NY: Oxford University Press, 1996), 173; Michael A. Mullet, The Catholic Reformation (New York: Routledge, 1999), 30-31. Mullet went on to speculate that the chief opponent to a Council was the Pope himself. Indeed, by the time of the Reformation, the Papacy had already developed a significant aversion to conciliar claims.

${ }^{91}$ Woodbridge, Church History, 212. 
of prevenient grace, at least in the justification of adults, to achieve such a balance. It is essential to explore the Decree Concerning Original Sin and the Decree Concerning Justification to understand Trent's contribution to the concept of prevenient grace.

The Council carefully avoided clearly defining the nature of original sin. It limited itself to saying, first, that original sin is; second, that sin is transmitted by propagation as a result of the rebellion of Adam against God; third, that the loss of holiness and justice, guilt, and death are the drastic effects of original $\sin .{ }^{92}$ Finally, that although human freedom of will "was by no means extinguished," it is "weakened in its power and [is] downward bent.. ${ }^{93}$ In this condition, humans are by nature powerless to liberate themselves from the power of Satan and death. ${ }^{94}$

At this point the Council recognized that humans are in need of God's grace as a remedy for restoration, regeneration, and help. It is obvious that the Council understood that prevenient grace came to humans in different ways and times. On the one hand, during infant baptism, prevenient grace works as an infused power that regenerates, remits the guilt of original sin, and makes the soul "innocent, immaculate, pure, guiltless, and beloved by God." 95 On the other hand, prevenient grace in adults works as a helping, quickening, calling, illuminating power of the Holy Spirit persuading human beings to

${ }^{92}$ H. J. Schroeder, Canons and Decrees of the Council of Trent: Original Text with Translation (St. Louis, MO: B. Herder Book, 1941), 21-22.

${ }^{93}$ Trent, 30.

94 Trent, 30.

95 Trent, 23. 
"turn themselves from the fear of divine justice to consider the mercy of God." ${ }^{96}$ The Council clearly declares,

the beginning of that justification is to be derived from the predisposing grace (praeveniente gratia) of God, through Jesus Christ, that is to say, from His vocation (vocatione), whereby, without any merits existing on their parts, they are called; that so they, who by sins were alienated from God, may be disposed through His quickening (excitantem) and assisting (adjuvantem) grace, to convert themselves to their own justification, by freely assenting (assentiendo) to and co-operating (cooperando) with that said grace. ${ }^{97}$

In this manner, the Council understood that prevenient grace is not an integral part of justification, but only the initial preparation for justification. In other words, for the conciliar theologians, prevenient grace prepares the soul for the subsequent work of justification. For that reason, the effects of prevenient grace are limited to producing hope and trust in God's mercy, to quicken the wounded freedom of the will, to love God as the source of all justice, to move the soul against the desire of sin and rebellion, to repent, and finally to resolve to receive baptism. ${ }^{98}$ The Council believed that the effects of

${ }^{96}$ Trent, 31-33.

${ }^{97}$ Trent, 31-32. The Latin Version of Chapter V in the Decree Concerning Justification is: "Declarat praetera, ipsius justificationis exordium in adultis a Dei per Christum Jesum praeveniente gratia sumendum esse, hoc est, ab ejus vocatione, quia nullis eorumexsistentibus meritis vocantur, ut qui per peccatta a Deo aversi erant, per ejus exitantem atque adjuvantem gratiam ad covertendum se ad suam ipsorum justificationem, eidem gratiae libere assentiendo et cooperando, disponantur, ita ut tangente Deo cor hominis per Spiritus Sancti illuminationem neque homo ipse nihil omnino agat, inspirationem illam recipiens, quipped qui illam et abjicere potest, neque tamen sine gratia Dei movere se ad justitiam coram illo libera sua voluntate possit. Unde in sacris litteris cum dicitur: 'Convertimini ad me, et ego convertar ad vos,' libertatis nostrae admonemur; cur respondemus: ' Convertere nos Domine ad te, et convertemur,' Dei nos gratia praeveniri confitemur," Trent, 310 .

${ }^{98}$ Trent, 34-35. 
prevenient grace dispose humans toward God and the desire for a new life in conformity to the divine law as it is expressed in passages like Hebrews 11:6; Matthew 9:2; 28:19; Mark 2:5; Acts 2:38; and 1 Kings 7:3.

There are some points to underline in the Council's understanding of the doctrine of prevenient grace. First, the Council recognizes that prevenient grace is granted to human beings as a gift of God. There is no human merit involved in the reception and resulting effects of prevenient grace in the believers. Second, the Council insisted on the resistible operation of prevenient grace, at least to adults. Human beings must cooperate with prevenient grace in order to receive its benefits. The Council's active synergistic view of salvation grants equal emphasis to God's prevenient grace and human freedom of will. Such a reality can be perceived in the biblical texts on which the Council relied. Citing Zacharias 1:3, the Council strongly supports human liberty (libertati nostra) and the freedom of will power of humans "to convert themselves to their own justification" and to turn "themselves from the fear of divine justice." Prevenient grace, therefore, is only a concurrent instrument with the freedom of will. Although by pointing to Lamentations 5:21 the Council emphasizes the necessity of God's prevenient grace (gratia praeveniri) as the prime "vocation, quickening, helping, and illumination" of the Holy Spirit, ${ }^{99}$ it defended an equal participation of the human will in the work of conversion. Therefore, for the Council, the cooperation of the human will with God's

${ }^{99}$ Trent, 32. 
prevenient grace is not limited to the acceptance (assentiendo) of God's proposition of salvation; rather, it implies a meritorious work on the part of the believer.

Molina defends the Council's view on the role of prevenient grace in human salvation. Indeed, he continually refers to the Council as his authority on prevenient grace. ${ }^{100}$ For Molina, prevenient grace is an instrument of the Holy Spirit to prevent [precede], excite, draw, and invite the human freedom of will to believe, hope, love, and repent. ${ }^{101}$ It is not possible to attain salvation without this unmerited prevenient and exciting grace of the Holy Spirit. ${ }^{102}$ This particular assistance works not only in the will but also in the intellect of the individuals. Then, prevenient grace illuminates the human

${ }^{100}$ Luis de Molina, Concordia del libre arbitrio con los dones de la gracia y con la presciencia, providencia, predestinación y reprovación divinas, trans. Juan Antonio Hevia Echevarría (Oviedo, España: Pentalfa, 2007), 72, 79, 322, 323, 326-328. There are limited sources that analyze the concept of prevenient grace in Molina's writings. Kirk R. MacGregor's biography on the life and work of Molina barely touches on the concept of prevenient grace. Although he quotes Molina affirming, "free will is not sufficient without prevenient grace," he does not completely develop the implications of the will and the prevenient grace as equal cause of accepting divine salvation in Molina's soteriology. I believe that in many instances for Molina prevenient grace is only a passive agent of conversion in the hands of human freedom of will. This means that I found more emphasis on the role of free will than on the role of prevenient grace in Molina's conceptualization. See MacGregor, Luis de Molina, 70-71; 72n117.

101 "Afirmanos que la gracia previniente a través de la cual el Espíritu previene, excita, atrae e invita al arbitrio del adulto a realizar los actos de creer, tener esperanzas, amar y arrepentirse, es un instrumento a través del cual el Espíritu Santo concurre de modo eficiente e influye con el propio arbitrio sobre la producción de estos actos, cuando el arbitrio consiente con esta gracia e influye y coopera con ella en estos actos," Concordia, 326-327.

102 “Ciertamente, no depende de ningún mérito, ni de ningún vigor, que, por estas disposiciones, recibanos la gracia preveniente, sino que, cada vez que se nos otorga, únicamente se nos confiere ... en virtud de los méritos de Cristo, del don de Dios y, por ello, de manera absolutamente misericordiosa," Concordia, 82. 
understanding to assent with the articles of faith and, at the same time, invites the will to live according to the assent of faith. ${ }^{103}$ In this manner, Molina assumes the preceding role of the preaching, teaching, and reading of the Word and the teaching of the Church to the divine infusion of God's prevenient grace. To this point, it is clear that for Molina, similar to the Council, the role of prevenient grace is limited to that of an assisting instrument to the human will and understanding in the beginning of the process of believing and understanding. ${ }^{104}$

In this manner, Molina assumes a human free will and understanding able to cooperate with the assistance of prevenient grace. Certainly for Molina the human will is wounded and the intellect clouded, but they are essential agents to the act of believing and faith. Molina elsewhere defends the idea that the prevenient grace of God accomplishes nothing without the consent of human free will. This means that the effectual working of prevenient grace is not coming before [preceding] but simultaneous [concurrent] with the freedom of will. The following passages illustrate how Molina presents the equal concurrence of the freedom of will and prevenient grace:

103 "Pero como la voluntad no necesita de la gracia previniente en menor medida que el entendimiento y como también depende de su libre mandato que el entendimiento asienta a los artículos de fe, ciertamente, por medio de un movimiento no menos especial, la gracia previene e invita a la voluntad a ordenar el asentimiento de la fe," Concordia, 80 .

104 “De aquí se sigue que la gracia que antecede al primer acto [de creer] no sea un don habitual sino una iluminación del entendimiento y una moción y afeción de la voluntad por auxilios particulares, que cesan en cuanto aparece el primer acto de creer," Concordia, 80. 
The supernatural assenting of faith depends in an efficient manner simultaneously as much on God, through his internal vocation and prevenient grace, as on the free will that consents and freely cooperates" with God. ${ }^{105}$

We should not merely attribute to prevenient grace that some who listen to the Gospel becomes believers and others do not, but also we must have a place for the free will of each individual, which means a person having at his/her disposal the help of grace that a sinner might or not be converted. ${ }^{106}$

Although God does not distribute the gift of prevenient, exciting, and cooperative grace to come to Christ according to the qualitative use of free will and the expected cooperation of the adult, but only according to His will, yet the voluntary cooperation derived of the free will that the adult naturally possesses ... depends on such an adult, with one or more helps, coming to Christ here and now. ${ }^{107}$

Because our will is free-when God touches the will and incites it by prevenient grace - to give consent or rejection and by it to consummate or not the act of believing, of having hope and of repenting, certainly it is evident, in the first place, that our free will and the prevenient grace are two parts of one total cause of the act of believing, of having hope and of repenting in the required venue to reach salvation.

Secondly, each one of these acts depends on both the influence of the free will and of the prevenient grace. ${ }^{108}$

105 "El asentimiento sobrenatural de la fe depende simultaneamente de modo eficiente tanto de Dios, a traves de su vocacion interna y su gracia previniente, como del libre albedrio que consiente y coopera libremente en este asentimiento," Concordia, 85.

106 "No sólo debemos atribuir a la gracia previniente que algunos de los que escuchan el Evangelio se conviertan y otros no, sino que también debemos dejar un lugar al libre arbitrio de cada uno, del que depende que, teniendo a su disposición el auxilio de la gracia, un pecador se convierta o no," Concordia, 99.

107 “Aunque Dios no distribuya los dones de gracia previniente, excitante y cooperante para llegar a Cristo según la cualidad del uso del libre albedrío y de la cooperación prevista del adulto, sino tan sólo según su voluntad, sin embargo, de la cooperación libre del propio arbitrio que el adulto posee de manera innata ... depende que el adulto, con unos y otros auxilios, llegue a Cristo aquí y ahora," Concordia, 103.

108 “Como nuestro arbitrio es libre - cuando Dios lo toca y lo incita por medio del auxilio de la gracia previniente - para otorgar su consentimiento o su rechazo y, por ello, realizar o no el acto de creer, de tener esperanzas o de arrepentirse, ciertamente, es evidente, en primer lugar, que nuestro libre arbitrio y la gracia previniente son dos partes de una sola causa total del acto de creer, de tener esperanzas o de arrepentirse del modo 
On this basis, Molina also sees prevenient grace as a divine intervention in those who arduously prepare themselves for grace. In this case, Molina is not completely at odds with Biel's Facientibus. He clearly says that God is willing to confer prevenient grace on those who "attempt" or "are ready to attempt" to use the "natural strengths" of their free will. ${ }^{109}$ For Molina this preparation to receive God's prevenient grace, even though unmerited, depends "in great measure on the free will of who will receive [it] and the impulse of the Church and its ministers." 110 This ecclesiological and robust synergistic emphasis of prevenient grace seems to concede to the human freedom of will equal meritorious accomplishment to the prevenient grace of God in the working of salvation.

Elsewhere Molina assumes that humans could freely use their freedom of will with the assistance of prevenient grace to reach salvation. Molina closely follows Aquinas in this aspect, limiting prevenient grace to an accident in the soul that God uses to guide humans to him. ${ }^{111}$ So for Molina, similar to Aquinas, prevenient grace exists in

requerido para alcanzar la salvación y, en segundo lugar, que cada uno de estos actos depende del influjo tanto del libre arbitrio como de la gracia previniente," Concordia, 304.

109 “Cuando quiera que el libre arbitrio, en virtud de sus fuerzas naturales, intente o esté presto a intentar todo aquello que está en sí mismo - tanto en realación a lo que hay que aprender y abrazar en materia de fe, como en relación al dolor de los pecados para alcanzar la justificación-, Dios conferirá la gracia previniente o los auxilios con objeto de que el hombre obre como es necesario para alcanzar su salvación," Concordia, $87,88,99$.

\footnotetext{
${ }^{110}$ Concordia, 99.

${ }^{111}$ Concordia, 304-305.
} 
the human soul just as any other accident, like the potential of becoming a swimmer or a musician, exists in an individual. This accidental nature of prevenient grace is so central for Molina that he believes that prevenient grace is part of the process of salvation only because God has sovereignly decided to follow this method of a mutual concurrence between human will and prevenient grace. However, God as primary cause, if he wished, could lead the human freedom of will to salvation without mediating the role of prevenient grace. ${ }^{112}$ It seems to me that Molina used the concept of prevenient grace to avoid the charge of Pelagianism and at the same time to make human freedom of will central in his soteriology without negating God's sovereign work.

\section{Prevenient Grace in the Theology of the Protestant Reformation}

A consideration of the way in which an individual turns away from sin to grace and submission to God was a central focus of the Reformers. In this context, the role of human will and God's sovereign grace increasingly become a point of contention. On this topic, Martin Luther and John Calvin shared similar views, namely that later developments came to a more rigid and limited understanding of the role of free will in the work of salvation. They emphasized God's sovereign grace and human weakness to do something to receive salvation to the point that it appears that humanity is only a passive agent in the whole process of redemption.

112 See Concordia, 247-248. 


\section{Martin Luther}

Martin Luther in his most important treatise on the topic of grace and free will, The Bondage of the Will, clearly stated that the role of humans in salvation is to recognize humbly that "salvation is utterly beyond [their] own powers, counsel, will, and works, and absolutely depending on the will, counsel, pleasure, and work of another, that is, of God only."113 I think that Arminius would not have dissented with this statement if presented in the context of human spiritual inability. Nevertheless, because it is in the context of a strict view of God's sovereign and necessary will in predestination, surely he would have argued against it. Luther said that God knows "nothing by contingency, but that he foresees, and does all things according to His immutable eternal, and infallible will." 114 Luther defended this view even before he started the Reformation. In this Commentary on Romans, Luther stated that divine providence or predestination is the unique foundation "from which it originally comes that one believes or not, is rid of sin or not rid of it." 115 God, therefore, offers salvific grace in a sovereign, irresistible, and limited way to those who have been elected for eternal salvation, while he leaves behind the rest in eternal condemnation. More importantly, in this view of predestination, for Luther, "our depraved will" does not participate, not even in the acceptance of the grace of God.

${ }^{113}$ Martin Luther, The Bondage of the Will, trans. Henry Cole (Lexington, KY: Legacy, 2011), 21.

114 Ibid., 13.

${ }^{115}$ Martin Luther, Commentary on the Epistle to the Romans, trans. J. Theodore Mueller (Grand Rapids, MI: Kregel, 1976), xxiii-xxiv. 
Arminius possessed several books by Luther, among them, Luther's Commentary on Galatians and the treatise on free will, de Servo Arbitrio. ${ }^{116}$ For this reason, it is quite surprising and intriguing that Arminius mentioned Luther as one of the great theologians that opposed predestination. ${ }^{117}$ Assuming that Arminius actually read Luther's de Servo Arbitrio, how is it that he concluded that Luther rejected or modified his views on predestination? One could speculate that Arminius refered to his knowledge of Lutheranism from the Formula of Concord and Melanchthon's writings, and consequently assumed that Luther at that time believed in a similar idea. Unfortunately, Arminius did not offer any evidence to support his assertion.

However, I believe that we can speculate that Arminius noted in Luther's treatise two aspects of God in relation to salvation: the "revealed God" and the "hidden God." 118 The revealed God of Scripture, for Luther, must be the focus of human beings. God revealed in Jesus and the Scripture is the paramount evidence of God's will to impart salvation and restore humanity to His image. Luther relegates predestination, the work of the hidden God, to a secondary plane, encouraging his readers to "worry first about Christ and the Gospel," along with recognizing personal sin, and the grace of God. ${ }^{119}$ In this context, Luther clearly explained that the revealed God desires that "all men should be

${ }^{116}$ C. O. Bangs, The Action Catalogue of the Library of J. Arminius: A Facsimile Edition with an Introduction (Utrecht, the Netherlands: Hes, 1985), 14, 18.

${ }^{117}$ Gunter, Arminius and His Declaration, 128; Decl. Sent. in Works 1:642.

${ }^{118}$ Luther, Bondage of the Will, 50-51.

${ }^{119}$ Luther, Commentary on Romans, xxxiv. 
saved," and "comes to all by the word of salvation." ${ }^{, 120}$ He came to affirm further that the frustration of God's desires is not the fault of God, but the rejection by the human will.

However, even in this case he made clear that the human will needs the irresistible action of God in order to accept that salvation. ${ }^{121}$ Luther wondered why everyones's will is not overpowered by God; however, he thinks that the motive remains unrevealed in the "hidden God" of predestination.

Arminius surely would have found some inconsistency in Luther's conceptualization of predestination. He might even have thought that Luther was open to some participation of the will given his concept of the "revealed God." 122 In any case, Arminius was certain that Lutherans during his lifetime did not agree with Calvin on the concept of limited grace. While further studies are necessary to establish to what degree, if any, Luther changed his view on predestination, Arminius was completely sure that Phillip Melanchthon had clearly departed from the teaching of unconditional predestination. In the next section, I will consider Melanchthon's teaching on prevenient grace as a possible source of Arminius's concept of prevenient grace. However, before

${ }^{120}$ Luther, Bondage of the Will, 51.

${ }^{121}$ Luther, Bondage of the Will, 51. He says: "But why that Majesty [God] does not take away or change this fault of the will in all, seeing that, it is not in the power of man to do it; or why he lays that to change the will, which the man cannot avoid, it becomes us not to inquire."

${ }^{122}$ For Arminius, different than Luther, God's will is clearly revealed in Scripture. Arminius believed that to say that there is a "hidden" and a "revealed" will in God amounts to affirms that "there are two wills in God, contrary to each other." Then, he concluded that if there is something "hidden" in God, it is not His will, but His knowledge of those whose who will be save or will be damned. See, Rom. IX, in Works, 3:505-506; Gomarus Exam., in Works, 3:556-558. 
considering Melanchthon, it seems to be important to review briefly what I consider Calvin's rejection of prevenient grace.

\section{John Calvin}

John Calvin also emphasized the primacy of God's sovereign grace. I will not spend time describing Calvin's position on this topic because his conceptualizations on irresistible grace, free will, and predestination are, I think, well known. Rather, I will briefly discuss Calvin's understanding of the concept of prevenient grace as a healing and irresistible power to restore and more precisely to recreate the will.

Calvin clearly affirmed the anticipation of grace to the human will in salvation. For him - and I would say for Arminius - it cannot be otherwise because the depravity of the will is so profound that it "cannot move and act except in the direction of evil." ${ }^{123}$ It is this depraved will that is in need of conversion. Calvin returned to Philippians 1:6 in order to explain not only the initiation of conversation but the whole process, all the way to the final result. He wrote: "God begins the good work in us by exciting in our hearts a desire, a love, and a study of righteousness." ${ }^{, 24}$ This most certainly is language akin to the concept of prevenient grace, and I think that Arminius would completely embrace it. Nevertheless, Calvin did not stop at this point. He continued by affirming that a more precise reality is that God works "by turning, training, and guiding our hearts unto

${ }^{123}$ John Calvin, Institutes of the Christian Religion, trans. Henry Beveridge (Peabody, MA: Hendrickson, 2008), 181.

${ }^{124}$ Ibid., 182. 
righteousness, and he completes this good work by confirming us unto perseverance." Note that Calvin immediately changes from a language of gentle persuasion, akin to the concept of prevenient grace, to a language of overpowering grace that inevitably and without human approval concludes in the perseverance of grace. Surely Arminius would have disagreed with this view. As we will see, Arminius believes that between the "exciting" work of grace and the fulfillment of the work resulting in perseverance in faith, human acceptance of the gift of salvation was a most central part in the process of salvation.

Thus, Calvin did not believe that prevenient or preventing grace gives human beings the opportunity to accept the salvific work of God. He rejected the teaching that the will "once it is prepared, .. . performs a part in acting." ${ }^{126}$ Rather, he believed that preventing grace irresistibly “corrects, or rather destroys, our depraved will, and also substitutes a good will from himself." 127 There is no human participation. He makes that clear, affirming: "Inasmuch as it is prevented [preceded] by grace, I have no objection to your calling [free will] a handmaid; but inasmuch as when formed again, it is the work of the Lord, it is erroneous to say that it accompanies preventing grace as a voluntary attendant." 128 In sum, for Calvin, the human will is sovereignly "formed again" from its

${ }^{125}$ Calvin, Institutes, 182.

${ }^{126}$ Ibid., 183.

127 Ibid.

${ }^{128}$ Ibid. 
total depravity and death, but it does not have any role in accepting the preventing grace of God once it has been freed.

In this respect, we will find in the works of Phillip Melanchthon and the Anabaptist preachers a more positive view on the role of human will in salvation after the work of prevenient grace. I will turn now to consider their conceptualization of this topic.

\section{Phillip Melanchthon}

A central and controversial aspect of Phillip Melanchthon's theology is his understanding about the participation of human beings in the work of conversion. ${ }^{129} \mathrm{His}$

${ }^{129}$ For a complete account of Melanchthon's views on the relationship between God's grace and human freedom of will, see articles IV, V, IX, X, XV. Phillip Melanchthon's three causes of conversion and his latter rejection of predestination and divine determinism in salvation evidence his synergistic soteriology. Early in 1521, Melanchthon sided with Luther in the controversy with Erasmus. It is possible to read in his work a strong view of determinism and predestination in salvation. However, the influence of Erasmus guides Melanchthon to consider carefully the early Church Fathers like Basil of Caesarea, Chrysostom, and Gregory of Nazianzus. The influences of these early theologians appears in the 1526 Loci Communes edition, in which Melanchthon divides the human freedom of will into temporal and spiritual spheres, and restricts the captivity of the will to the spiritual realm. By 1535, with the publication of the Loci Communes and Commentary on Romans, we see a definitive, clear, and final rejection of deterministic predestination as well as the acceptance of a role for human free will in the spiritual realm. This freedom of will in spiritual matters is however restricted to the acceptance of salvation and always under the influence and support of the Word (Scriptures) and the Holy Spirit.

Nevertheless, Melanchthon scholars are divided on this issue. On the one hand, several scholars suggests a discontinuity in Melanchthon's understanding of the role of free will in salvation from a strict view of predestination to a synergistic view of God's grace and human freedom of will. See James William Richard, Philip Melanchthon: The Protestant Preceptor of Germany 1497-1560 (New York: G. P. Putnam's Sons, 1898); E. P. Meijering, Melanchthon and Patristic Thought: The Doctrines of Christ and Grace, the Trinity, and the Creation (Leiden, the Netherlands: Brill, 1983); Timothy J. Wengert, "Philip Melanchthon and the Origins of the 'Three Causes' (1533-1535): An

Examination of the Roots of the Controversy over the Freedom of Will” in Irene Dingel, 
polemical statement about the three causes of conversion has created much debate among scholars down to the present day. In the 1535, 1543, and 1559 editions of Loci

Communes Melanchthon writes about the three causes in conversion, namely "the Word, the Holy Spirit and the Will which assents to and does not contend against the Word of God." 130

Robert Kolb, Nicole Kuropka, and Timothy J. Wengert, Philip Melanchthon: Theologian in Classroom, Confession, and Controversy (Göttingen, Germany: Vandenhoeck \& Ruprecht, 2012); Gregory B. Graybill, Evangelical Free Will: Philipp Melanchthon's Doctrinal Journey on the Origins of Faith (New York: Oxford University Press, 2010); Oliver K. Olson, Matthias Flacius and the Survival of Luther's Reform (Wiesbaden, Germany: Harrasswitz, 2002); Clyde L. Manschreck, Melanchthon: The Quiet Reformer (Eugene, OR: Wipf and Stock, 2008); Robert Stupperich, Melanchthon, trans. Robert H. Fisher (Philadelphia: Westminster, 1965). On the other hand, other scholars believe that Melanchthon's view did not undergo any change regarding this topic. They argue that Melanchthon always supported Luther's view. See Michael Rogness, Melanchthon: Reformer without Honor (Minneapolis, MN: Augsburg, 1969); H. Ashley Hall, Philip Melanchthon and the Cappadocians: A Reception of Greek Patristic Sources in the Sixteenth Century (Göttingen, Germany: Vandenhoeck and Ruprecht, 2014); Timothy J. Wengert, Human Freedom, Christian Righteousness: Philip Melanchthon's Exegetical Dispute with Erasmus of Rotterdam (New York: Oxford University Press, 1998).

${ }^{130}$ Phillip Melanchthon, Melanchthon on Christian Doctrine: Loci communes 1543, trans. J. A. Preus (St. Louis, MO: Concordia, 1992), 43; see also Phillip Melanchthon, The Chief Theological Topics: Loci Praecipui Theologici 1559, trans. J. A. O. Preus, 2nd ed. (St. Louis, MO: Concordia, 2011), 61, 63. Lutheran leaders and scholars expressed their opposition to Melanchthon's synergism in the Lutheran Formula of Concord (1577). They affirmed that in conversion "through the preaching and the hearing of His Word, God is active, breaks our hearts, and draws man, so that through the preaching of the Law man learns to know his sins ... and experiences genuine terror, contrition and sorrow. . . and through the preaching of the holy Gospel. . . there is kindled in him a spark of faith which accepts the forgiveness of sins for Christ's sake." Evidently, this declaration accentuated the unique role of divine agency through the Spirit and the Word negating any role to the human freedom of will. However, it seems to me that the declaration is broad enough to permit interpretations that could grant a role to the human will, at least in the acceptance of salvation. 
In this way, Melanchthon clearly suggests that humans have a role in conversion. However, according to Melanchthon, human participation arises from God's grace and not from human nature or ability. Like Luther, Melanchthon supported a radical view on the total corruption, moral inability, and spiritual perversity of human beings. In its natural condition without the assistance of the Holy Spirit, the human heart "is in darkness, it most ardently loves itself, seeks its own desires and wishes nothing but carnal things and despises God." ${ }^{\prime 31}$ This is because sin, says Melanchthon, eroded the natural powers, leaving human nature "very weak." ${ }^{132}$ At this point, Melanchthon came to distinguish the impact of sin on human's faculties. While human capacities of understanding — like the intellect, the power to distinguish between good and evil, and the power to comprehend the teaching of the law-were clouded but not lost; the "good virtues in the heart and will," namely, the love of God, the trust in God, and the true fear of God, were completely lost. ${ }^{133}$ In such a condition, humans are incapable of returning to God and performing spiritual good. Melanchthon made this point absolutely clear:

When we speak about this great ruin of human powers, we are talking about free will, for man's will and heart are wretchedly imprisoned, impaired, and ruined, so that inwardly man's heart and will are unlike the divine law, offensive and hostile to it, and man cannot by his own inward natural powers be obedient. ${ }^{134}$

${ }^{131}$ Loci, 52.

132 Phillip Melanchthon, Melanchthon on Christian Doctrine: Loci communes 1555, translated by Clyde L. Manschreck (Grand Rapids, MI: Baker Book House, 1965), 52.

${ }^{133}$ Loci 1555, 52-53.

${ }^{134}$ Loci 1555 , 52. In the 1559 edition, he added: "The mind of the unregenerate is filled with doubts about God, their hearts are without true fear of God, without true trust, 
Melanchthon discovers this reality not only in the daily evidence from the "outward behavior" of the unregenerate, but more precisely, from the internal evidence of the Word of God. In the testimony of the Word of God, Melanchthon affirms, it "is certain that men [human beings] do not have the freedom to overcoming [the] depravity which is born within us."

\section{The Role of Human Will}

Melanchthon, however, did not believe that humans are passive agents in the work of conversion. He states, "we should not think that a man is a piece of wood or a stone, but as we hear the word of God, in which punishment and comfort are put forth, we should neither despise nor resist it." ${ }^{, 136}$ Undoubtedly, for Melanchthon, the will of man in conversion either resists the divine actions like Pharaoh and Saul, or freely assents like David in his conversion. ${ }^{137}$ "For the will could disregard the Word of God, as Saul did of his own free will. But when the mind, hearing and sustaining itself, does not resist or indulge in hesitation, but with the aid of the Holy Spirit tries to assent, in this contest the will is not idle. ${ }^{\prime 138}$ It is precisely in this context that He adjoins the three causes: The Word of God, the Holy Spirit, and the human will.

and they have enormous desires to act against the law of God," Loci Praecipui, 59.

\footnotetext{
${ }^{135}$ Loci Praecipui, 59.

${ }^{136}$ Loci 1555,60 .

${ }^{137}$ Loci Praecipui, 62.

${ }^{138}$ Ibid., 61.
} 
He quoted from Chrysostom and the biblical record to support his view.

According to Melanchthon, Chrysostom assured that "God draws man, however, he draws the one who is willing, not the one who resists,",139 and the biblical record in Revelation 3:20 and the parable of the lost son (Lk 15:11-32) clearly show that divine agency expects a human response to the invitation to salvation. He further said about the role and balance between God's aid and human response, "the Son of God will be with us, come to us, and will give us aid, because he knows our misery," but "only let us not push him away, but ask him for help" ${ }^{\text {140 }}$ (Heb 13:21; Col 1:9, 10).

\section{The Prevenient Grace of God}

Melanchthon, however, finally came to qualify the participation of human beings in the work of salvation. He continued supporting the necessity of an initial, previous, and necessary work of the divine grace before any human capacity to respond to or accept salvation. He openly reverted to the doctrine of prevenient grace to explain the relation between the Word, the Holy Spirit and human freedom of will. Melanchthon affirmed that good spiritual works "arose out of preceding [prevenient] grace and assenting will.," ${ }^{, 41}$ Before the positive answer of the human will, Melanchthon affirmed

\footnotetext{
${ }^{139}$ Loci $1555,60$.

${ }^{140}$ Loci 1555, 60.
}

${ }^{141}$ Loci Praecipui, 61. Melanchthon refers here to the ancient view of Christian theologians like Basil and Chrysostom, "Veteres dixerunt: Praecedente gratia, comitante voluntate, bona opera fieri," Philip Melanchthon, Philippi Melanthonis Opera Quae Supersunt Omnia, ed. Henricus Ernestus Bindseil, Corpus Reformatorum 21 (Brunsvigae: apud C. A. Schwetzke Et Filium, 1854), 658. 
that "God has previously turned us, calls, warns, and helps us." ${ }^{\text {"142 }}$ Thus, in this manner, he manifestly articulated the concept of prevenient grace in his theology of conversion in that he primarily exalted the central role of the Holy Spirit as the "divine motion in us. 143

He stated, "God is not received where the Holy Spirit has not first enlightened and kindled the understanding, will, and heart." ${ }^{" 144}$ Explaining 1 Corinthians 2:11, Melanchthon concludes: "the natural man knows not the Spirit of God, that is, if God is not present in our natural power, in our heart and soul ... if we are not comforted by the gospel and Holy Spirit." Likewise, Ephesians 4:24 suggests that the "Holy Spirit is not a lazy being; he kindles light and fire in the soul and heart in such a manner that the soul and heart also possess a better knowledge of God and an initial love and longing for Him." 145 In this manner, Melanchthon argued, "God both made the beginning in them and will further strengthen them." ${ }^{146}$ His doctrine of prevenient grace, therefore, is strongly pneumatological.

${ }^{142}$ Ibid., 61. "Deus antevertit nos, vocat, movet, audivat," Melanthonis Opera, 658.

${ }^{143}$ Loci 1555,162 . The centrality of the Holy Spirit's role in conversion, in the beginning of Christian life, and in salvation is widely present in Melanchthon's soteriology. He states, without the work of the Holy Spirit "in our hearts, there is not true faith, and comfort and love to God. (Romans 8:9, 16; John 15:5; Galatians 4:6)," Loci, 60.

${ }^{144}$ Loci $1555,52$.

${ }^{145}$ Loci $1555,60$.

${ }^{146}$ Loci 1555, 60. Melanchthon quotes several biblical passages to support his conclusions. For instance, Luke 11:9, 13; Mark 9:24; and Romans 8:26. 
Melanchthon further believed that the work of the Holy Spirit through prevenient grace is made possible by the Scriptures. For him, the Holy Spirit uses the preaching of the gospel and the law to awaken the sinner to accept and receive God's grace. ${ }^{147}$ In this manner, the teaching and preaching of the Holy Scriptures becomes a central element in the work of prevenient grace. He assured the reader, "God is present in this comfort. He is active, through the external word, and kindles faith in the heart. But these are all together - the external word, contemplation of the external word in us, and the Son of God, who works through the external word, manifests the eternal Father, speaks to the heart, and gives the Holy Spirit, which produces love and joy in God." ${ }^{\text {148 }}$ Melanchthon consistently maintained the anticipation of God's prevenient grace in the work of the Holy Spirit and the Word to human willingness. In the following quotation, he explains this reality:

Concerning free will we have said elsewhere that since in conversion our will must be moved by the Word of God, this Word must certainly be heard, and since with the Word of God the Holy Spirit does His work, raising up and helping our hearts, we are to sustain ourselves with faith. Nor should we idly indulge in mistrust or vices against conscience, nor trouble the Holy Spirit, but rather give assent to the Word of God and follow the Holy Spirit. In this spiritual struggle we feel that our will in contending against doubt and other vices is not idle. ${ }^{149}$

In this sense, Melanchthon speaks of a freedom of grace or freed will enabled by the power of the Holy Spirit and the message of the Word of God. There should be no doubt that Melanchthon refers to prevenient grace here because Martin Chemnitz (1522-

${ }^{147}$ Loci $1555,154-155$.

${ }^{148}$ Loci $1555,158-159$.

${ }^{149}$ Loci Praecipui, 169. 
1586), a balanced Lutheran theologian, makes it clear in his commentary on Melanchthon's De Humanis Veribus Seu De Libero Arbitrio. He states: “The things which have been said about prevenient, preparatory, and operating grace have this meaning, that the initial stages in conversion are not ours, but God-through the Word and divine inspiration — goes before us, moves and impels our will. After this movement of the will has been accomplished by divine power, then the will is not purely passive, but, moved and aided by the Holy Spirit, it ceases to resist and assents and is co-operative (synergos) with God." 150

Another important aspect of Melanchthon's doctrine of grace and freedom of will is the universality of grace. He clearly states that "the promise is universal and in God there are not conflicting wills." ${ }^{, 151}$ For this reason, prevenient grace is the universal working of the Holy Spirit in the human heart. For Melanchthon the reason why some people accept while others reject God's offer of salvation is not to be found in an obscure counsel of divine election, but in the lively relationship of human free will, the Word, and the Holy Spirit. He advises that when considering Christian conversion and the remission of sin, "questions about predestination should be laid aside." ${ }^{152}$ He subsequently states, "the preaching of repentance pertains to all people, so the promise of grace is universal

${ }^{150}$ Martin Chemnitz, Loci Theologici, trans. J. A. O. Preus, vol. 1 (St. Louis, MO: Concordia, 1989), 249.

${ }^{151}$ Loci Praecipui, 63.

${ }^{152}$ Ibid., 168. 
and brings reconciliation to all." ${ }^{, 153}$ For him, the "universal statements" in biblical passages like Matthew 11:28, John 3:16, Romans 3:22, 11:32, and 1 Timothy 2:4 undoubtedly affirm the universality of the "promise of grace." 154

To conclude, Melanchthon understood the work of prevenient grace as the conjoined work of the Trinity, especially the Holy Spirit and the Scripture that universally empowers and kindles the human will. More specifically, prevenient grace is the work of the Holy Spirit as agent of salvation working through the preaching of the gospel and law to cleanse the heart, to destroy the natural enmity of humans against God, and to empower the will to accept the offer of salvation. Then, conversion is finally made possible by the free response of human beings, because for Melanchthon the necessary assistance of God's grace does not erode the necessary working of the human will. Certainly, according to Melanchthon, the axiom "praecedente gratia, comitante voluntate" speaks of the necessary prevenient work of the Holy Spirit and the Word, but also that "the will follows and does not resist." "155

Although more studies and careful analysis of Melanchthon's and Arminius's works needs to be done, Melanchthon could be regarded as the most important influence in Arminius's conceptualization of prevenient grace.

${ }^{153}$ Loci Praecipui, 168.

${ }^{154}$ Ibid.

${ }^{155}$ Loci 1555, 63. 


\section{Radical Reformers}

The radical reformers preached with greater emphasis on "the experience of regeneration (being "born again") by the Spirit of God over forensic justification."156 Such at times overemphasis could result in a misleading identification of the Anabaptist preachers with Pelagian and semi-Pelagian soteriology. However their equal emphasis on God's prevenient grace demonstrates Anabaptist dependence on grace as the primary source of human salvation. Certainly, Anabaptist preachers did not use the precise words “prevenient grace." However, it is clear that they considered conversion to be the synergistic work of the Holy Spirit and the free response of human freedom of will.

The theology of Balthasar Hubmaier, the greatest Anabaptist theologian of the first generation, clearly resembles the concept of prevenient grace. ${ }^{157}$ Hubmaier emphasizes that before faith and individual conversion, the Holy Spirit moves human beings toward God by "an inner illumination ... through the Word of God." 158 The

${ }^{156}$ R. Olson, Story of Christian Theology, 415; see also Harold S. Bender, "The Anabaptist Vision" in Guy F. Hershberger, ed., The Recovery of the Anabaptist Vision: A Sixtieth Anniversary Tribute to Harold S. Bender (Scottdale, PA: Herald, 1957), 42-43; Robert Friedmann, The Theology of Anabaptism: An Interpretation (Scottdale, PA: Herald, 1973), 91.

${ }^{157}$ See R. Olson, Story of Christian Theology, 421-422 and Arnold C. Snyder, Anabaptist History and Theology: An Introduction (Kitchener, Ontario: Pandora, 1995); 87-89. Olson came to conclude that Hubmaier was "the first synergist" and his doctrine of a mandatory and previous illumination of the Holy Spirit before the free human decision to accept Christ was an Arminian view of salvation before Arminius.

${ }^{158}$ Hubmaier, Schriften, 384; Balthasar Hubmaier, Balthasar Hubmaier: Theologian of Anabaptism. ed. H. Wayne Pipkin and John H. Yoder (Scottdale, PA: Herald, 1989), 431-432. In a dialogue with Leonhart, Hubmaier further explains his view on conversion in this way: "Leonhard: How does God draw and call a person? Hans: In two forms, outwardly and inwardly. The outward drawing occurs through the public 
process of salvation begins with an "inward spiritual rebirth and regeneration.",159

Regeneration is necessary because in the "fall, grace and freedom were to such a degree obscure and lost that, without an especial and new grace of God, man could not know what was good or evil., ${ }^{160}$

Then, the illumination of the Holy Spirit through the Scriptures restores the human free will, regenerating its lost "perception of good and evil in the sight of God."161 Hubmaier's theology of prevenient grace and the resulting capacity of human freedom of will to accept God's offer of salvation as the beginning of Christian life is clearly described in his treatise On Free Will. He points out that the soul in its natural power is "blind and uncomprehending" of heavenly things, but after regeneration through Christ, the soul

has been awakened by the Word of God-jolted, warned, and led by the Heavenly Father through his comforting, his threatening word, his promise, his benefits, his punishments, and all other means; made whole through his dear Son; also enlightened through the Holy Spirit ... thereby the soul now again comes to know what is good and what is evil. It has recovered its lost freedom. ${ }^{162}$

proclamation of his holy gospel ... the inward drawing is this, that God also illuminates the person's soul inwardly, so that it understands the incontrovertible truth, convinced by the Spirit and the preached of the Word," quoted by Snyder, Anabaptist History and Theology, 88.

${ }^{159}$ Snyder, Anabaptist History and Theology, 75.

${ }^{160}$ Balthasar Hubmaier, On Free Will, in George Huntston Williams ed., Spiritual and Anabaptist Writers (Philadelphia: Westminster, 1962), 128.

${ }^{161}$ Hubmaier, On Free Will, 128.

${ }^{162}$ Ibid., 124. 
Hubmaier concludes his synergistic view of salvation by affirming that after such regeneration the soul "can freely and willingly be obedient ... choose the good ... and reject and flee from evil" or follow after the flesh. ${ }^{163} \mathrm{He}$ advises believers about the necessary consent of the freed will with God's grace because God "created you without your aid, but he will not save you without your aid.",164

Hubmaier's understanding of the doctrine of prevenient grace is by no means a novel contribution among the Anabaptist preachers. Indeed, it was the common consensus of most of the Anabaptist writers. Hans Hut and Hans Denck, similar to Hubmaier, emphasize an order of salvation that begins with coming to faith by the hearing of the Word under the influence of the Holy Spirit. ${ }^{165}$ Denck, in his treatise Divine Order, elaborates a synergistic view of salvation. He clearly depicts prevenient grace by affirming:

[God] gives everyone the change, grace and strength to be converted (Mt 19:26). The light which is the invisible Word of God shines into the hearts of all men who are born into the world [this is a clear reference to John 1:9]. For God has been in the

${ }^{163}$ Ibid., 124.

${ }^{164}$ Ibid., 125. What I criticize about Hubmaier is the extent of the regeneration, for he proposes that the work of the Holy Spirit is a complete restoration of the will to the same condition as in Eden. This assumption oversimplifies the evil condition of human beings after sin. To a certain extent, he seems to suggest a freedom of will capable of choosing good without the continual assistance of God's grace. It seems that restoration entails the granting of a "grace, health, and freedom through the merits of Jesus Christ our Lord that he is able again to will and to accomplish the good, even against the nature and will of his flesh, in which is nothing good," Ibid., 128.

${ }^{165}$ Hubmaier, Denck, and Hut believe that after the internal work of the Holy Spirit the order of salvation entails human repentance, water baptism, and Christian sanctified life. See Snyder, Anabaptist History and Theology, 67-72. 
world from the beginning and he gives everyone who will accept it free choice to become a child of God and to inherit the kingdom of the Father (Jn 1:12). ${ }^{166}$

Evidently, Denck believes that free choice in salvation is not the result of nature, but it is the result of God's prevenient grace.

Likewise, Conrad Grebel, Michael Sattler, Peter Riedemann, Pilgram Marpeck, Dirk Phillips, Menno Simons, and other Anabaptist preachers agree that the new birth occurs by the internal prevenient work of the Holy Spirit through the preaching of the Word. ${ }^{167}$ For instance, Arnold C. Snyder concludes that Michael Sattler's soteriology is akin to a long history of Christian theology of God's prevenient grace and "calling and man's subsequent response." 168

In sum, the Anabaptist view on conversion involves a synergistic soteriology. In such cooperation with grace, Anabaptist preachers emphasized an active and strong pneumatology as well as a positive and optimistic anthropology. Then, regeneration and new birth is the result of God's prevenient grace by the Holy Spirit and the "yieldedness"

${ }^{166}$ Hans Denck, "Divine Order" in Selected Writings of Hans Denck, ed. and trans. Edward J. Furcha and Ford Lewis Battles (Pittsburgh, PA: Pickwick, 78-79. He also asserts that "the more a man seeks himself and his own, the more fully he is assured by God's Spirit in his heart and conscience that he does wrong (Wisd 12:23). He would lose himself has done his best ... Of course, we cannot do any good of our own making (II Cor. 3:5), except for the Word that has come unto His own (i.e., unto all creatures), setting us free and making God's children of us, if we believe in Him (Jn 1:12)," (89).

${ }^{167}$ See William R. Estep, The Anabaptist Story: An Introduction to SixteenthCentury Anabaptism, 3ra ed. (Grand Rapids, MI: Eerdmans, 1996), 201-235; Friedmann, 91-98; C. Arnold Snyder, Following in the Footsteps of Christ: The Anabaptist Tradition (Maryknoll, NY: Orbis, 2004), 59-60.

${ }^{168}$ Arnold C. Snyder, The Life and Thought of Michael Sattler (Scottdale, PA: Herald, 1984), 176, 178, 181. 
of the will to God. ${ }^{169}$ Snyder qualifies the Anabaptist understanding of human participation in conversion by pointing to the spiritual concept of yieldedness, giving up, or stopping striving; here he refers to the German word Gelassenheit that surprisingly refers to "'the doing' that is 'doing nothing." "170 In other words, human participation in conversion is restricted to the free acceptance of God's salvific gift in Christ.

\section{Summary and Conclusion}

In this chapter we have seen that prevenient grace has a long history in Christian theological conceptualizations of salvation. Prevenient grace, therefore, is a concept well integrated into soteriological ideas in Christianity. Augustine introduced the term in his controversy with Pelagius primarily to indicate the priority of God's grace in salvation before human will and actions. According to Augustine, prevenient grace is a free gift of God's love mediated to individuals through the internal illumination of the Holy Spirit that likewise works through the work [agency or instrumentality?] of the Church in preaching and teaching the Scriptures. Augustine further taught that prevenient grace heals and empowers the will making it possible for humans to respond to God's offer of salvation, and resulting in faith and salvation.

In close harmony with Augustine, the Second Council of Orange decided to use the doctrine of prevenient grace to counteract the so-called Semi-Pelagian teaching of John Cassian and his followers. For the Council, prevenient grace is the priority of God's

\footnotetext{
${ }^{169}$ See Snyder, Following in the Footsteps of Christ, 40-41.

${ }^{170}$ Ibid., 41.
} 
mercy before human willingness to accept the divine offer of salvation. Prevenient grace is a gratuitous gift obtained by the internal work of the Holy Spirit in the human heart. This anticipatory divine grace restores human free will. Therefore, it precedes human faith and good will toward spiritual life, leading humans to accept baptism and a life of sanctity. At this point, the Council is unclear about the role of baptism in prevenient grace. The Council affirms both that prevenient grace leads to the acceptance of baptism and that prevenient grace is obtained at the moment of baptism.

Although the Fathers did not explain this apparent contradiction, it is possible to think that they were referring to the different experiences of adults and children in the sacrament of baptism. While prevenient grace anticipates the decision of baptism in adult believers, it is received by children at the moment of baptism. Another important point to note in the deliberations of the Council is that the Fathers did not follow Augustine by affirming that God's grace could be resisted and totally rejected by individuals. Prevenient grace works in advance in the human soul, but the human will must concur with the actions, calls, and offers of the Holy Spirit in order to reach the desired end of salvation.

Thomas Aquinas used the doctrine of prevenient grace in many instances like Augustine. However, there are some differences. Aquinas accepted that prevenient grace is the priority of divine action before a person's first response to God. However, he believed that prevenient grace was not limited to the beginning of conversion, but that it works throughout the whole process of salvation. This is akin to his understanding and acceptance of the Aristotelian principle of the first mover; namely, that every movement 
first needs a mover. Thus, divine prevenient grace is the antecedent or first mover of all other effects of divine grace.

The Council of Trent turned from Aquinas' attention to the concept of prevenient grace as the starting point of conversion in the experience of mature individuals. The Conciliar Fathers described the role of prevenient grace in Augustinian terms. Prevenient grace is the initial point of justification thanks to the helping, quickening, and illuminating power of the Holy Spirit that heals and empowers the will. However, unlike Augustine, the Council contested that prevenient grace is not an integral part of justification. In their understanding, prevenient grace is limited to being a preparative work for justification. Another important difference between the Council and Augustine and Aquinas is the assertion of the Conciliar theologians that humans are able to resist the work of prevenient grace. For Augustine, though prevenient grace is not irresistible, it is nonetheless intrinsically efficacious and infallible.

Melanchthon, like Augustine, strongly affirms the initiatory role of God's grace in human salvation. Prevenient grace, according to Melanchthon, is the work of the Holy Spirit illuminating the human understanding, will, and heart. It also empowers and heals the human freedom of will and gives individuals the power to accept God. The Holy Spirit works especially through the preaching and teaching of Scripture and produces faith, love, and joy in God. Melanchthon also stressed the point that prevenient grace does not erode the decision of human free will. The will must follow the divine initiative and grace.

While in Aquinas and Melanchthon, and most probably in Augustine as well, prevenient grace is a historical one-time experience, for the Anabaptist preachers, it 
consists of a continual and providential act of God. Like Augustine, the Anabaptist preachers regard prevenient grace as the internal illumination of the Spirit through the Word of God. Prevenient grace restores the human's lost perception of good and evil and bestows the freedom of will to follow the spiritual good. Humans have a role in accepting God's grace, but the Anabaptists made clear that such a role consists in "doing nothing," that is, not resisting the pull of God's preventing grace.

In certain ways, Catholic and Protestant theologians describe prevenient grace in a similar manner. All of them point to the anticipatory and gratuitous nature of prevenient grace. They also point to the empowering and healing role of prevenient grace upon the human freedom of will. Likewise, they agree that prevenient grace is the work of the Holy Spirit that illuminates the heart by an internal call and the external appeal of Scriptures. However, Melanchthon and the Anabaptist preachers' view on the synergistic role of prevenient grace differs from that of Aquinas and the Conciliar theologians, and both differ with Augustine's view.

First, Augustine does not accept a synergistic view of the working of prevenient grace. For Augustine, prevenient grace is always effective at overcoming the human freedom of will. Aquinas and the Conciliar fathers have an active synergistic view of prevenient grace, in which the human will should cooperate with the existing measure of grace that it has. Differently, Melanchthon and some of the Anabaptist preachers have a passive synergism in which the role of free will is limited to the acceptance of salvation or to offering no resistance to the appeals of the Holy Spirit. 


\section{CHAPTER 4}

\section{PREVENIENT GRACE IN ARMINIUS'S THEOLOGY I}

\section{Introduction}

The doctrine of prevenient grace is not a secondary idea in Jacobus Arminius's soteriology, but a central theme that pervades every aspect of Arminius's doctrine of grace. This chapter discusses the nature of prevenient grace in Arminius's theology. It looks for the definition and nature of prevenient grace, and then offers a definition of the concept of prevenient grace and explores the nature of this divine grace. It also discusses the operation of divine prevenient grace in the human heart. It proposes that according to Arminius, prevenient grace as the working of the Holy Spirit operates not only externally but also internally in the human heart. The chapter, however, begins by considering the kind of human being that is in need of prevenient grace according to Arminius. The necessity to consider first the sinfulness of humanity underlines the reality of the human impossibility of finding a solution to the problem of sin. It is an individual desperately in need of regeneration for whom Arminius believed prevenient grace was the primary and most urgent solution.

\section{Prevenient Grace: The Need for Regeneration}

One of the most common charges against Arminius's theology is that he negated original sin and the total depravity of human beings. This is obviously untrue. John 
Wesley, a pro-Arminian theologian, clearly states that "no man that ever lived, not John Calvin himself, ever asserted original sin ... in more strong, more clear and express terms, than Arminius has done."1 This conclusion could be one expected from a sympathizer of Arminius, ${ }^{2}$ but William Cunningham and R. C. Sproul, both prominent Calvinist theologians, admitted Arminius's orthodoxy in this respect. Cunningham states that "the statements of Arminius himself, in regard to the natural depravity of man ... are full and satisfactory." In a similar way Sproul asserts that "Arminius not only affirms the bondage of the will, but insists that natural man, being dead in sin, exists in a state of moral inability or impotence. What more could an Augustinian or Calvinist hope for from a theologian?"4 It therefore seems important to review Arminius's doctrine of total depravity to understand the nature and place of the concept of prevenient grace in his theology.

${ }^{1}$ John Wesley, The Question, What is an Arminian? Answered, quoted in Benjamin Myers, Milton's Theology of Freedon (Berlin, Germany: De Gruyter, 2006), 139-140, n114.

${ }^{2}$ See for instances, R. Olson, Arminian Theology, 141-146; Bangs, Arminius, 337-340; James Meeuwsen, "Original Arminianism and Methodistic Arminianism Compared," The Reformed Review, vol. 14, no. 1 (September, 1960): 21-23.

${ }^{3}$ William Cunningham, Historical Theology: A Review of the Principal Doctrinal Discussions in the Christian Church Since the Apostolic Age (Edinburgh: T \& T Clark, 1863), 2:389.

${ }^{4}$ R. C. Sproul, Willing to Believe: The Controversy over Free Will (Grand Rapids, MI: Baker Books, 1997), 128. 


\section{Human Beings in Need of Prevenient Grace: \\ Original Sin and Total Depravity}

Arminius recounts with particular attention and deeply Scriptural perception the depraved condition of all humanity since the fall. As a natural and spiritual result of the sin of Adam, all humans have an inherited depraved nature, a depravity that extends to all human faculties. In such a condition, humans are totally devoid of moral and spiritual capacities, making their minds completely blinded to all spiritual matters. Arminius acknowledges the pervasive effects of Adam's original sin upon his offspring, stating that "the whole of this sin, however, is not peculiar to our first parents, but is common to the entire race and to all their posterity, who, at the time when this sin was committed, were in their loins, and who have since descended from them by natural mode of propagation, according to the primitive benediction: For in Adam 'all have sinned.' (Romans 5:12),5

As a result of this inherited sinful nature, Arminius enlists several actual conditions of humans as sinners pointing specifically to the extent of corruption in each of the faculties of human beings. Concerning human reason and spiritual life Arminius states that "the mind of man, in this state, is dark, destitute of the saving knowledge of God, and, according to the Apostle, incapable of those things which belong to the Spirit of God; (1 Corinthians 1:18, 24, 2:14, Romans 1:21 -22, Ephesians 4:17-18, 5:8, Titus

\footnotetext{
${ }^{5}$ Pub. Disp. VII, in Works, 2:156.
} 
3:3.) ${ }^{\prime 6}$ Therefore, humans are "devoid of original righteousness and holiness (Romans 5:12, 18-19).,

Arminius not only pointed out the darkness of human mind that affects human understanding and knowledge, he also called the attention to the carnal nature of reason. Quoting 1 Corinthians 3:3, he links the carnality of reason with the enslavement of reason to the desires, passions, and commands of the flesh. ${ }^{8}$ Therefore, for Arminius, a carnal reason represents the offspring from where all human evil actions spread and where the constant fight against the work of the Spirit occurs, according with Galatians 5:17. This means that Arminius would reject any understanding of human depravity that describes human reason as untouched by sin.

Human affections are equally depraved, Arminius states: "to the darkness of the mind succeeds the perverseness of the affections and of the heart, according to which it hates and has an aversion to that which is truly good and pleasing to God; but it loves and pursues what is evil (Romans 8:7, Jeremiah 13:10, 17:9, Ezekiel 36:26, Gen 6:5, 8:21, and Matthew 15:19)." As a result, all humans "are by nature children of wrath" (Eph $2: 3) .^{10}$

${ }^{6}$ Pub. Disp. XI, in Works, 2:192.

${ }^{7}$ Pub. Disp., VII, in Works, 2:157.

${ }^{8}$ Rom. VII., in Works, 2:653.

${ }^{9}$ Pub. Disp. XI, in Works, 2:193.

${ }^{10}$ Pub. Disp., VII, in Works, 2:156. 
The corruption of human affections particularly wounded the human freedom to will. Arminius clearly stated that "the free will of human being towards the true good is not only wounded, maimed, infirm, bent, and weakened; but it is also imprisoned, destroyed, and lost." ${ }^{, 11}$ Consequently, freedom of will is not only sick, but it is completely dead and unable to perform true good. It is evident that Arminius desired to be as clear as possible to avoid misunderstandings regarding his position on human free will. For that reason, he recalls Augustine, affirming that in every given situation corrupted individuals will misuse their freedom of will to choose evil. He states, "all unregenerate persons have freedom of will, and a capability of resisting the Holy Spirit, of rejecting the proffered grace of God, of despising the counsel of God against themselves, of refusing to accept the gospel of grace, and of not opening to Him who knocks at the door of the heart; and these things they can actually do, without any difference of the Elect and of the Reprobate." ${ }^{12}$ Therefore, humans are actually free, but free only to do spiritual evil and oppose God's purpose.

Human brokenness extends to the internal power or disposition toward the good and right. Humans experience "the utter weakness (impotentia) of all the powers to perform that which is truly good, and to omit the perpetration of that which is evil, in a due mode and from a due end and cause, (Matthew 7:18, 12:34, John 6:44, Romans 8:7,

${ }^{11}$ Pub. Disp. XI, in Works, 2:192.

${ }^{12}$ Art. XVII, in Works, 2:721. 
7:5, 6:20, 2 Timothy 2:26.)"13 Quoting Romans 3:10-19 Arminius concludes that humans are truly "dead in sin."14

Arminius's concept of total depravity underlines the idea that human sinfulness separates us from God. In such a condition and depravity, humans are completely unable to oppose their sinful nature sinning necessarily and yet willingly. Furthermore, individuals cannotnot and do not want to restore the separation existing between them and God. They are unwilling and unable to seek for spiritual things or attain righteousness and holiness. Arminius comes to agree with the biblical record that human imagination "is only evil continually" (Gen 6:5). Therefore, all humanity is "obnoxious to condemnation, and to temporal as well as to eternal death." 15

Having dealt with the actual, discouraged, and most probably permanent condition of human beings, Arminius insists that we must look with hope to Christ. Christ, the mediator between humans and God, has opened a way of salvation by providing a substitute, mediator, and liberator in Christ Jesus — who has made atonement for our sins. ${ }^{16}$ In this manner, Arminius situates the solution to human brokenness completely outside of human nature, human effort, and human will.

${ }^{13}$ Pub. Disp. XI, in Works, 2:193.

${ }^{14}$ Ibid, 2:194.

${ }^{15}$ Pub. Disp., VII, in Works, 2:156-157.

${ }^{16}$ Arminius clearly states the hopeless condition of humanity, while at the same time pointing to a way of solution in Christ. He says, "with these evils they would remain oppressed for ever, unless they were liberated by Christ Jesus." Pub. Disp., VII, in Works, 2:157. 
Arminius was in complete agreement with Article 14 of The Belgic Confession, which insists that "humans are nothing but the slaves of sin and cannot do a thing unless given to them by heaven." ${ }^{17}$ What Arminius opposed was the Reformed solution of an irresistible working of divine grace. Rather, he proposed prevenient grace as the solution to the infirmity of will. Although the powers of the will "are not only debilitated and useless" or "have no power whatever," Arminius argues that they could be "assisted and excited by divine grace" resulting in regeneration and freedom. ${ }^{18}$ With this in mind, I will turn to the analysis of the concept of prevenient grace in Arminius's theology, as for Arminius prevenient grace is the solution that counteracts the evilness of human nature.

\section{The Nature of Prevenient Grace}

A definition of prevenient grace in Arminius's writings is critical in order to understand the role and centrality of this doctrine in his theological conceptualization of salvation. However, it seems important first to discuss Arminius's understanding of grace before turning to define the more specific qualities of prevenient grace.

\section{Three Main Concepts of Grace}

Arminius describes grace using three main concepts: he writes of grace as a divine attribute, an infused gift, and continual assistance. First, Arminius understands grace primarily as an attribute of God that is significantly manifested in the salvation of

${ }^{17}$ Arthur C. Cochrane, ed., Reformed Confessions of the Sixteenth Century (Louisville, KY: Westminster John Knox, 2013), 198.

${ }^{18}$ Pub. Disp., VII, in Works, 2:192. 
sinners. Grace is, first and foremost, the divine solution to human sinfulness. For that reason, he defines grace as an unmerited divine disposition or favor "towards poor miserable sinners."19 Because of grace, God willingly communicates "his own good" and kindly love to his "creatures, not from merit or debt. ${ }^{20}$ Arminius connects grace as a divine attribute directly with two other divine affections - goodness and love. ${ }^{21}$ As a result, for Arminius it is because of God's goodness and love that mercy is extended "toward creatures that have sinned." 22 At this point Arminius returns to Romans 5:8 and Ezekiel 16:6 to argue that even sin could not stand as an "obstacle" between God's love and his creatures. The greatest demonstration of grace is to be found in God's loving gift of his only Son (John 3:6), a sacrifice for the sin of the whole world. This divine gracious action opens a way for humans to obtain three gifts of grace: eternal life, justification, and adoption as sons and daughters of God. ${ }^{23}$

Second, Arminius also adds that grace is an infusion of a "holy disposition" to incline human will and actions toward "good desires." ${ }^{24}$ Arminius closely relates this new spiritual disposition to regeneration and preparation for conversion. It is by this grace that

${ }^{19}$ Arminius, Declaration of Sentiments, in Gunter, Arminius and His Declaration, 140.

${ }^{20}$ Pub. Disp., VI, in Works, 2:131.

${ }^{21}$ Ibid

${ }^{22}$ Ibid.

${ }^{23}$ Arminius, Declaration of Sentiments, in Gunter, Arminius and His Declaration, 140.

${ }^{24}$ Ibid., 141. 
the Holy Spirit stirs up human hearts to accept the gospel of redemption. This infused grace as divine gift and healing power renews the human will, understanding, and affections. As we will see, this description of grace is closely related but not limited to the initial or prevenient grace of God. The continual infusion of grace goes beyond conversion because the gifts of "faith, hope and love" are also infused into those regenerated by the Spirit. ${ }^{25}$ By the fruit of the Spirit the believers are able to "think, will, or do anything that is good." 26 In this way, Arminius does not limit the concept of grace to a mere divine attribute and attitude, but also expands it to refer to an active and personal participation of the Holy Spirit in the inward life of believers. Indeed, with the concept of the infused nature of grace, Arminius once more finds occasion to remark on the impossibility of regarding grace as a human achievement, accrediting it solely to God's mercy and work.

The nature of the "infusion" of grace in Arminius has been widely discussed. Frederic Platt, reading Arminius through the lens of Aquinas, believes that the internal work of the Holy Spirit in Arminius's theology is "regarded as a kind of quasimetaphysical substance or energy." ${ }^{27}$ Similarly, Howard Slaatte asserts that for Arminius the Spirit (here I think he is likewise referring to grace) is "seemingly regarded as a kind

${ }^{25}$ Arminius, Declaration of Sentiments, in Gunter, Arminius and His Declaration, 140.

${ }^{26}$ Ibid.

${ }^{27}$ Frederic Platt, “Arminianism” in Encyclopedia of Religion and Ethics, ed. J. Hasting (New York: Charles Scribner's Sons, 1908), 1:810. 
of quasi-metaphysical substance or energy." ${ }^{28}$ By contrast, Hicks contends that infusion is just a reference to "the personal presence of the Spirit." ${ }^{29}$ Bangs, similar to Hicks, asserts that "grace is not a force; it is a person, the Holy Spirit." ${ }^{, 30}$ Likewise, F. Stuart Clarke rejects any identification of grace with a "quasi-independent property," arguing that for Arminius grace is the Holy Spirit's benevolent influence and work. ${ }^{31}$ In a similar tone, Mark A. Ellis contends against the notion of grace as a force or energy, affirming instead that for Arminius grace is "the Holy Spirit." 32

I believe that Arminius uses the word "infusion" to refer to the inward illumination of the Holy Spirit in human hearts. For Arminius, this influence is not transmitted by an impersonal power, but through the personal conviction of the Holy Spirit. Some evidence supports such a conclusion. First, Arminius continually relates the work of grace to the work of the Holy Spirit. Indeed, he believes that to resist grace is to resist the Holy Spirit. Later in this chapter, I will discuss further the role of the Holy Spirit in the divine work of grace. However, it seems important here to present clear evidence that Arminius rejected the concept of infusion as a metaphysical power in the

${ }^{28}$ Howard Slaatte, The Arminian Arm of Theology: The Theologies of John Fletcher, First Methodist Theologian, and his Precursor, James Arminius (Washington, D.C.: University Press of America, 1978), 54.

${ }^{29}$ Hicks, "Theology of Grace in . . Jacobus Arminius," 50.

${ }^{30}$ Bangs, Arminius, 343.

${ }^{31}$ Clarke, The Ground of Election, 77.

${ }^{32}$ Mark A. Ellis, "Simon Episcopius's Doctrine of Original Sin," (PhD diss., Dallas Theological Seminary, 2002), 108. 
soul. In his Apology against the Thirty One Articles, Arminius disproved the concept of habitual grace as a substance poured "into all those to whom the gospel is preached.,"33 Instead, Arminius understood grace in this context as the "assistance of the Holy Spirit." ${ }^{34}$ In this example, it is evident that Arminius rejected the concept of grace as an infusion of a metaphysical force. For Arminius, it is rather the presence and the influence of the Holy Spirit.

Second, although the Latin words for infusion have a varied range of meaning, the semantic meaning of influo and infundo have the potential to go both ways. They can refer to something flowing or pouring in (an impersonal force/energy or medicine) as well as a personal influence showing in or influencing another personal identity (instilling ideas and feelings). ${ }^{35}$ Also, the reading of Arminius's understanding of "infused grace" depends more on the reader's metaphysical understanding of "grace." It is possible, therefore, to read Arminius as evoking the medieval Catholic metaphysical understanding of grace as a power or energy that comes from God, but which, at the same time, can be manipulated by the church to be poured into the soul of the believer. Alternatively, it is also possible to read Arminius against the Protestant understanding of grace as referring to the action of God through the Holy Spirit. I think that Arminius more probably is not following Aquinas's concept of infused grace, as Slaatte and Platt suggest, but instead

${ }^{33}$ Apology., Article VIII, in Works 1:763-764.

${ }^{34}$ Ibid., 1:764.

${ }^{35}$ P. G. W. Glare, Oxford Latin Dictionary (New York: Oxford University Press, 1982), 904 - 905. Arminius commonly used the word infundo, see for instances Opera, 122, 145. 
that he agrees with his fellow Reformer theologians even when he uses scholastic categories in his construction of theology.

Slaatte's view imagines a disconnection between the person and the work of the Holy Spirit, a disconnection not present in Arminius's theology. Taking Platt's and Slaatte's conclusions to their logical end would mean that for Arminius grace as a quasidivine substance operates somewhat independent of the actions of the Holy Spirit. However, it is Arminius himself who in his writings continually and widely equates grace with the actions of the Spirit. Therefore, it seems more fitting to read the concept of “infusion” of grace in Arminius's writing as a reference to a personal, salvific, and relational Spirit-to-human relationship. For Arminius, God does not operate through an “impersonal force or energy," but through a person, the Holy Spirit, who establishes a genuine friendship with the believers. While for Aquinas grace needs a sacrament to be transmitted, for Arminius a sacrament is not necessary, only the action of the Spirit.

However, it is still likely that Arminius is influenced by Aquinas in understanding "infused grace" as the work of the Holy Spirit shown in and influencing the life of a believer. This is because Aquinas also relates divine grace as the indwelling of the Holy Spirit or divine love in the human heart. Although it is almost inevitable sacramentally and metaphysically to understand Aquinas's concept of infused grace primarily as an independent energy or force separated from the Holy Spirit in the Summa Theologica, it is also Aquinas who closely relates grace to the actions and the indwelling of the Holy Spirit in the human heart. In other words, while in the Summa Aquinas describes grace more as an impersonal energy proceeding from God but in disconnection from the Holy Spirit, in the Commentaries on John and Romans, for instance, he sees grace as the 
personal actions of the Spirit in the human soul. ${ }^{36}$ If Arminius were following Aquinas in this respect, it is safe to suggest that he was primarily reading the Aquinas of the Commentaries, rather than the Aquinas of the Summa Theologica.

The third main concept in Arminius's description of grace is that after regeneration, grace is a "perpetual assistance and continued aid of the Holy Spirit." The gracious work of the Holy Spirit is not limited to regeneration, but it continually strengthens and preserves the life of faith. In other words, for Arminius, believers must have the continual assistance of the Spirit of grace to remain sanctified and in relation with God. Much as the regeneration to a new spiritual life is impossible without grace, so too the life of faith and sanctity and perseverance in grace demands the continuous assistance of grace. ${ }^{37}$ Arminius strongly emphasizes the continuing and cooperating nature of grace after conversion to counter the accusation of Pelagianism against his theology.

Thus, Arminius in his definition and understanding of grace links grace primarily to God's nature and attributes and the work of the Holy Spirit. For Arminius, it is because God loves humans that the Holy Spirit works in the life of sinners.

${ }^{36}$ Thomas Aquinas, Commentary on the Gospel of John, vol. 1, Chapters 1-8, trans. Fr. Fabian R. Larcher, O.P., ed. The Aquinas Institute (Lander, WY: The Aquinas Institue, 2013), 110-113; Thomas Aquinas, Commentary on the Gospel of John, vol. 3, Chapters 13-21, trans. Fabian Larcher, O.P., and James A. Weisheipl, O.P. (Washington, D.C.: The Catholic University of America Press, 2010), 70-74; 85-88. See also Gilles Emery, O.P., "The Holy Spirit in Aquinas's Commentary on Romans," in Reading Romans with St. Thomas Aquinas, ed. Matthew Levering and Michael Dauphinais (Washington, D.C.: The Catholic University of America Press, 2012), 127-162.

${ }^{37}$ See, Arminius, Declaration of Sentiments, in Gunter, Arminius and His 


\section{Distinctions of Grace}

Arminius, like his contemporaries, categorizes the effects or functions of salvific grace into two main groups. First, salvific grace directly effects liberation, regeneration, conversion, and faith. Second, salvific grace sustains continual growth in the Christian life, permanence in the union with Christ, and assurance of salvation. Arminius identifies this second category as efficient, secondary, subsequent, cooperating, concomitant, accompanying, and opening grace or entering grace. The first distinction he calls sufficient, primary, preceding, prevenient, exiting, moving, operating, and knocking. ${ }^{38}$ By expanding the categorization of grace, Arminius desires to increase clarity, specificity, and caution in his treatment of the doctrine of grace. For confusion in clearly distinguishing these categories, says Arminius, could lead a person into dangerous mistakes and even quite easily into heresy. ${ }^{39}$

These categories, therefore, serve Arminius to explain the operation of grace. However, he does not believe in different ontological kinds of grace. Instead, he is defending different effects or functions of divine grace. Arminius clearly states that "co-

\section{Declaration, 141.}

${ }^{38}$ Apology, Article XVI, in Works, 2:18. See also Priv. Disp., LXX, in Works, 2:451. "Quarto, salutaris gratia vel pro ipfa prima gratia acciditur, vel pro secunda, pro præveniente vel subsequente, pro operante, vel pro cooperante: pro pulsante vel aperiente, vel ingrediente," Opera, 158. See also Stanglin and McCall, 152.

${ }^{39}$ Ibid. He said: "unless a man properly distinguishes each of these [the different categories of grace], and uses such words as correspond with these distinctions, he must of necessity stumble, and make others appear to stumble . . . it is evident with what caution persons ought to speak [ubi] on subjects, on which the descent into heresy, or into the suspicion of heresy, is so smooth and easy." 
operating and accompanying grace, differs neither in kind nor efficacy from that exciting and moving grace which is called preventing and operating, but it is the same grace continued." ${ }^{\prime 40}$ The present chapter will focus on the nature of the preventing or exciting grace in Arminius's writings.

\section{Prevenient Grace: Its Content and Definition}

It important to construct a workable definition of prevenient grace from Arminius's theological conceptualizations. Although Arminius did not offer a concise definition of the concept of prevenient grace, the doctrine permeates all Arminius's conclusions on salvation. Therefore, it is possible to build a precise definition of prevenient grace by tracing his teaching on grace over the course of his writings. As we have seen previously, he refers to this initial operative state of God's grace using a wide range of adjectives like "preceding, prevenient, preparative, preventing, exciting, and operating. ${ }^{, 41}$ If a definition of prevenient grace were to rely only on this set of words, then for Arminius the most prominent characteristic of prevenient grace is the anticipation of its operation to human freedom of will and actions. In other words, God is not dependent on human beings in his initiative to rescue them from the pit of sin.

Prevenient grace, therefore, precedes or goes before human desire for God's offer of salvation in order that God's saving actions may be possible and accepted. For

${ }^{40}$ Priv. Disp., LXX, in Works, 2:451.

${ }^{41}$ See Apology, Article IV, in Works, 2:749; Quest. VIII, in Works, 2:68; Pub. Disp., XI, in Works, 2:196; Priv. Disp., LXX, in Works, 2:451; Priv. Disp., LXXII, in Works, 2:454; Rom. VII., in Works, 2:544; Art. XV, in Works, 2:718; Art. XIX, in Works, 2:724; Perkins Exam., in Works, 3:472. 
Arminius, without prevenient grace all other effects of grace and human good actions would be altogether impossible. For that reason "subsequent or following grace," he says, "does indeed assist the good purpose of man; but this good purpose would have no existence unless through preceding or preventing grace. ${ }^{, 42}$ In addition, he strongly affirms that, "no man believes in Christ except he who has been previously disposed and prepared by preventing or preceding grace. ${ }^{\circledR 43}$ Then, for Arminius, by prevenient grace the Holy Spirit prepares the human heart for faith by softening, humbling, and illuminating it.

This divine work is accomplished by the direct work and strict supervision of the Holy Spirit. Indeed for Arminius, the Holy Spirit is the "principal cause" who "by exciting grace, excites, moves and incites" humans to "second acts;",44 that is, to faith, obedience, and conversion. Arminius understood the Holy Spirit as working in the human heart in two significant ways: First, prevenient grace as the external influence of the Holy Spirit persuades humans by calling, illuminating, convincing, influencing, and appealing to them by the admonitions of the law and the preaching of the gospel. Second, prevenient grace as regenerative power of the Holy Spirit transforms, heals, recreates, liberates, and regenerates human nature and freedom of will.

For Arminius, then, prevenient grace is primarily preparatory grace with special emphasis on the preaching of the law and the gospel. Prevenient grace as "quickening

\footnotetext{
${ }^{42}$ Pub. Disp., XI, in Works, 2:196.

${ }^{43}$ Art. XIX, in Works, 2:724.

${ }^{44}$ Priv. Disp., LXXII, in Works, 2:454.
} 
power" ${ }^{45}$ prepares humans by confronting them with the requirement of the law. The law's role is to "convict a man of sin, of the righteousness of God, to incite him to obedience, to convince him of his own weakness," but even more important, to provoke in humans "a desire to be delivered and seek deliverance." ${ }^{46}$ Immediately, Arminius here introduces the gospel. It is to those "prepared by the law" that "the grace of the gospel must be announced. ${ }^{, 47}$ By the preaching of the gospel the Holy Spirit illuminates human minds resulting in "evangelical faith," regeneration to a new life, and union, and

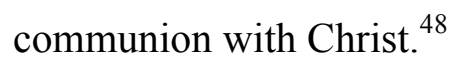

Arminius does not limit prevenient grace to having merely an external role of divine help. Otherwise, he would rightly be accused of Pelagianism or Semi-Pelagianism. Therefore, prevenient grace is not only the outward persuasion of the preaching of the world, but it is also the inward operation of the Holy Spirit. ${ }^{49}$ So for Arminius, prevenient grace is also the internal operation of the Holy Spirit in the human heart as a convincing, healing, and regenerative power. This prevenient and internal operation of the Holy Spirit intends to free, heal, and regenerate human freedom of will, thus enabling

${ }^{45}$ Rom. VII, in Works, 2:588.

${ }^{46}$ Rom. VII, in Works, 2:520.

${ }^{47}$ Ibid., 2:588.

${ }^{48}$ Ibid., 2:588; Arminius clearly says "Evangelical faith is an assent of the mind, produced by the Holy Spirit, through the gospel, in sinners, who through the law know and acknowledge their sins, and are penitents on account of them," Priv. Disp. XLIV, in Works, 2:400.

49 "Persuasion is managed outwardly by the preaching of the word, inwardly by the operation ... of the Holy Spirit," Perkins Exam., in Works, 3:315. 
humans to respond positively to the gospel. Arminius points to this operation of prevenient or awakening grace saying that "the regeneration and renewal by God in Christ through the Holy Spirit of all human capacities, including the intellect, affections, and will, is required for humanity to understand, esteem, consider, will, and perform that which is truly good." ${ }^{, 50}$ For Arminius, therefore, a freed will is able to respond positively to God's offer of salvation which presupposes the preventing work of grace in the human heart.

Before concluding the analysis of the nature and content of prevenient grace, it is important to highlight that for Arminius prevenient grace is not an integral part of human nature. He states that "the capability of believing in Christ is not bestowed on man by virtue of the first creation." ${ }^{, 51}$ This means that human beings in creation were not infused with a special power to overcome sin, as a remedy to be used after the fall. Rather, after the fall the Holy Spirit imparts to the human heart the power to believe in the message of the Gospel and in Christ. Arminius strongly affirms that God 'was prepared [after the fall] to bestow those gracious aids which were necessary and sufficient for believing in Christ." ${ }^{52}$ Therefore, for Arminius, they are not part of the natural capacity for faith and the acceptance of the Gospel. He insists that "faith in Christ belongs to a new creation.",53

${ }^{50}$ Arminius, Declaration of Sentiments, in Gunter, Arminius and His Declaration, 140; see Decl. Sent., in Works, 1:659-660. Emphasis added.

${ }^{51}$ Apology, Article XIX, Works, 2:24.

${ }^{52}$ Apology, Article XIX, Works, 2:23.

${ }^{53}$ Apology, Article XIX, Works, 2:24. 
It is the supernatural endowment of the Holy Spirit by prevenient grace as the divine answer to the problem of sin.

Therefore, I define prevenient grace in Arminius's theology as the previous and supernatural movement of God's goodness and grace toward sinful humans that precedes all other means of salvation. By the internal work of the Holy Spirit, prevenient grace illuminates the intellect, and liberates the will, giving humans the ability to understand and accept the call to believe, thus preparing the way for all subsequent means of salvation.

\section{Arminius's Biblical Support for the Concept of Prevenient Grace}

Unfortunately, Arminius did not do extensive exegetical work on biblical passages that support the doctrine of prevenient grace. Instead, Arminius constructed his doctrine of prevenient grace on the basis of only a few scripture verses. Elsewhere Arminius provided biblical passages, like Matthew 9:13; 10:11-13; John 5:25; 6:44; Acts 16:14; 1 Cor. 6:9-11; Galatians 5:19-25; Ephesians 2:2-7, 11-12; 4:17-20; 5:14; Titus $2: 12$; and $3: 3-7$, to emphasize the concepts of prevenient grace, calling, the universality of salvation, the transformation of believers into a new life, and the work of renovation by the Holy Spirit. From these passages, I would like to highlight two in particular: John 6:44 and Acts 16:14. Indeed, these two passages appear together almost everywhere in his conceptualization of prevenient grace. They describe the special and prevenient work of the Holy Spirit in the human.

Arminius frequently quoted John 6:44 in connection with the inability of sinners to respond to the offer of salvation and the necessity to be drawn in by grace and the 
work of the Holy Spirit previously. Speaking about the weakness of the human will, Arminius stated that God's prevenient grace as a supreme good "is properly in the gospel: 'No man can come to me, except the Father draw him." ${ }^{, 54}$ It was clear for Arminius that this passage teaches the anticipation of God's preventing and converting grace to human responsiveness to the evangelical gospel. In addition, using John 6:44 one more time, Arminius gave the name of "believers" only to those who believed in Christ "by the gratuitous and peculiar kindness of God. ${ }^{, 55} \mathrm{He}$ identified this peculiar and kind operation of God present in John 6:44 with the divine vocation to salvation to a "mankind constituted in the animal life. ${ }^{56}$ That is, without prevenient grace, humans would be no more receptive to the gospel than are animals.

Acts 16:14 became critical for Arminius to emphasize the necessity and concurrence of an internal and external operation of prevenient grace in the divine calling to salvation. According to Arminius, Lydia exemplified how the external preaching of the Word and the internal operation of the Holy Spirit illuminating the mind and affecting the heart produce "faith and credence" in the Word. ${ }^{57}$ This passage provided Arminius with the evidence that it is the prevenient grace of God that has the convicting power to transform a non-believer into a believer. Although he never did so directly, Arminius continually evoked Acts 16:4 in reference to the joining effort of the Word and the Holy

\footnotetext{
${ }^{54}$ Pub. Disp., XI, in Works, 2:193.

${ }^{55}$ Pub. Disp., XV, in Works, 2:228.

${ }^{56}$ Pub. Disp., XVI, in Works, 2:233.

${ }^{57}$ Pub. Disp., XVI, in Works, 2:234.
} 
Spirit in the conversion of individuals. Indeed, for him it is in this joining of Word and Spirit that grace becomes really effectual. ${ }^{58}$

The way in which Arminius worked with the biblical passages to understand divine prevenient grace now brings us to consider the operation of prevenient grace in his theology.

\section{The Operation of Prevenient Grace}

Arminius understood that the human will could resist the operation of God's grace. He believed that the polemic between his point of view and the views of his defectors can be encapsulated in this question: "Is the grace of God an irresistible force?"59 Arminius unhesitatingly responds that "the Scripture teaches that many persons resist the Holy Spirit and reject the grace offered" $" 60$ because "grace is not an omnipotent action of God which cannot be resisted by man's free will." ${ }^{, 61}$ These are not isolated passages. In fact, there are a great number of passages in which Arminius appeals to the concept of the resistibility of grace. He says, "the efficacy of saving grace is not consistent with that omnipotent act of God, by which he so inwardly acts in the heart and

${ }^{58}$ Pub. Disp., XVI, in Works, 2:234.

${ }^{59}$ Arminius, Declaration of Sentiments, in Gunter, Arminius and His Declaration, 141; Decl. Sent., in Works, 1:664.

${ }^{60}$ Ibid.

61 “Quia gratia non est omnipotents actio Dei, cui resisti a libero hominis arbitrio non possit." In Opera, p. 768; Perkins Exam., in Works, 3:470. 
mind of man, that he on whom that act is impressed cannot do otherwise than consent to God who calls him; or, which is the same thing, grace is not an irresistible force." ${ }^{.62}$

Arminius's denial of grace as an irresistible force makes clear that he rejects any construction of grace that makes a human "as passive as a corpse." ${ }^{63}$ However, while emphasizing the resistible nature of grace, he is not only and primarily defending human free will. In fact, he is equally concerned with the negative implications of an irresistible notion of grace for the conception of God's character and His salvific purposes.

As we have previously discussed, for Arminius prevenient grace involves the liberation of the enslaved will, and this in turn creates the possibility of acceptance of salvation. Arminius seems to resolve the tension between the corruption of the will and the capacity of the human will to choose salvation by collocating the freed will after the operation of prevenient grace has been effective in the human heart. However, this creates another tension in Arminius's theology. If prevenient grace could be resisted and if a positive response to prevenient grace demands a freed will, this means that prevenient grace itself at some moment in the experience of conversion cannot operate as a resistible force, but must be irresistible if imputed by God to humanity. Otherwise, humans could not respond to prevenient grace if they did not have the free will to respond prior to it.

Therefore, while considering the operation of prevenient grace, the question that is more pertinent to this study is: Could the resistibility of grace be extended to the

${ }^{62}$ Art. Article XVII, in Works, 2:722.

${ }^{63}$ Arminius, Declaration of Sentiments, in Gunter, Arminius and His Declaration, 121. 
operation of prevenient grace? I argue that the proper answer to this question is that, for Arminius, prevenient grace is both unavoidable and resistible. On the one hand, the initial grace that liberates the human will from its moral bondage and corruption and calls humans into communion with Christ works first in a monergistic and unavoidable way in the human heart long before individuals consider any spiritual good. On the other hand, humans are also able to reject and resist the operation by which prevenient grace produces actual faith and conversion. Subsequently, I will analyze key passages in Arminius's writings that support this conclusion.

\section{The Unavoidable Operation}

Throughout his writings, Arminius continually points to the unavoidable nature of prevenient grace. First, he states:

in the very (initio conversionis) commencement of his conversion, man conducts himself in a (merè passive) purely passive manner; that is, though, by a vital act, that is, [sensu] by feeling, he has a perception of the grace which calls him, yet he can do no other than receive it and feel it. But, when he feels grace affecting or inclining his mind and heart, he freely assents to it, so that he is able at the same time to with-hold his assent. ${ }^{64}$

In this quotation, we note two critical affirmations about conversion and grace.

First, Arminius asserts that in the beginning of conversion, human beings are "passive" agents. This is important to note because Arminius everywhere else in his writings defends the active and conscious participation of humans, although under the influence of

${ }^{64}$ Art. XVII, in Works, 2:722. Emphasis added. "Homo se habet in initio conversionis suae merè passive, id est, quanquam acione vitali, id est sensu percipiat gratiam vocatem, tamen non potest non illam accipere, $\&$ sentire, at ubi sentit gratiam menten \& cor assicientem, libere assentitur, ita ut possit non assentiri." De Voc. Pecatorum . . ., in Opera, 959. 
grace, in the work of salvation. However, Arminius makes clear here that he does not concede any operating participation to humans in the initiation of conversion. Indeed, rejecting a semi-Pelagian statement accredited to him, Arminius affirms that grace could not be excluded from "the commencement of conversion, (principio conversionis)" but insists that it always precedes good actions. ${ }^{65}$ This means that the Holy Spirit monergistically begins the salvific actions in favor of humans, who are, until that point, unable even to desire to be free from their miserable situation.

Second, according to the quotation above, Arminius further affirms that at the beginning of conversion, individuals cannot avoid receiving and feeling the "perception of grace." It seems critical to pay close attention to Arminius's language in connection with the perception of prevenient grace. To receive, accept (accipere from accipio), and to feel, perceive (sentire from sentio) describes the impression of prevenient grace on human intellectual reasoning as well as on human sense of intuition or feeling. Arminius does not want to divorce reason from emotions in the perception of prevenient grace. As a result, in the call to faith in Christ, the human will is incapable of deterring God's action by prevenient grace either by human reason or by feelings.

A third important implication of Arminius's teaching in this quotation is that prevenient grace works by "affecting and inclining the human mind and heart" toward the acceptance of salvation. Prevenient grace not only sufficiently but also effectively or

${ }^{65}$ Apology, Article XVII, in Works, 2:19. "Caeterum ad hunc articulum dico; nunquam nobis in mentem venisse istis verbis tam inconditis uti, quae primo statim intuitu gratiam excludunt à principio conversionis, quam nos sacimus semper $\&$ ubique praecedaneam, comitantem, subsequentem." in Opera, pp. 158-159. 
efficaciously affects human reason and feelings. For Arminius this means that by prevenient grace humans come to a real and reasonable conviction of sin and their necessity of salvation. However, for Arminius, this does not mean that humans necessarily submit to such a conviction and permit the Holy Spirit to continue working in their hearts and minds. It seems that it is precisely at this point that human sinful nature could react against the calling and the internal working of the Holy Spirit and thus could reject God's gracious gift.

Another important example in Arminius's writings is his claim that "it is unavoidable (necessum - necessary) that the free will should concur in preserving the grace bestowed, assisted, however, by subsequent grace, and it always remains within the power of the will to reject the grace bestowed and to refuse subsequent grace." ${ }^{\prime 66}$ This assertion points to the sovereign conferral of prevenient grace. Clearly, according to Arminius, prevenient grace is bestowed by the independent actions of the Holy Spirit. Arminius intentionally separates the action of concurrence of human freedom of will from the initial endowment of regenerative grace. Free will has no role in this initial divine movement, but in order for prevenient grace to lead on to salvation, the human will must necessarily or inevitably (necessum) concur with the invitation. In such a concurrence, free will is assisted by subsequent grace. Thus, the necessary (necessum)

${ }^{66}$ Perkins Exam., in Works, 3:470. "Quare necessum est liberum arbitrium concurrat ad conservandam gratiam datam, adjutum tamen a gratia subsequente; manet que semper in potestate liberi arbitrii gratiam rejicere, \& subsequentem repudiare" in Opera, p. 763. In this context, it is more accurate to translate necessum as necessary rather than as unavoidable. 
concurrence (concurrat) of human freedom of will with God's initial grace follows the conferral of prevenient grace. For Arminius, this is only possible for human free will because by enabling grace God has previously regenerated human freedom to respond to the offer of salvation. In other words, prevenient grace has liberated the will, thus giving it the ability to choose a response of faith. Nevertheless rejection of prevenient grace is possible because the freed will is not only free to accept God's prevenient grace, but alternatively to reject God's grace, due to the fact that the infirmities of the will remain.

Furthermore, discussing the sufficient and efficacious nature of grace, Arminius introduces a clear distinction between prevenient grace and subsequent grace. He says that prevenient and preparatory grace "are either sufficient or efficacious. For God 'prevenes' [prevents or precedes] sufficiently and efficaciously' and likewise 'prepares' sufficiently and efficaciously." ${ }^{\circ 67}$ In contrast, he asks whether "co-operative grace" does not work in a similar way; however, he does not provide an answer to that. Arminius argues, in this quotation against Perkins, that God's prevenient grace has located humans in a place where they are able to respond positively to salvation. It is only after humans have exercised their freed will that grace is finally effective or effectual. Arminius emphasizes that prevenient grace has sufficiently played its role not by overpowering free will (as Calvinist saw it) but by removing the infirmities of the will acquired by $\sin ,{ }^{68}$ so

${ }^{67}$ Perkins Exam., in Work, 3:472. "Quin \& illæ ipsæ gratiæ, prævenients nempe $\&$ præparans, aut sufficientes sunt aut efficaces. Prævenit n. Deus suffienter \& efficaciter, præparat itidem sufficienter \& efficaciter" in Opera, 769.

68 "It is part of grace not to take away, but to correct the nature itself, wheresoever it has become faulty," Perkins Exam., in Works, 3:474. 
that the will becomes able to accept the spiritual callings of the Holy Spirit. As Willen J. van Asselt and Paul H.A.M. Ables puts it: "Sufficient grace enables someone to believe, but it is effectual when someone actually believes. $" 69$

Indeed, Arminius further argues, if humans do not respond accordingly, God is not to be blamed. God has sufficiently provided the necessary means to salvation and has efficaciously worked in the human heart, in the sense that prevenient grace has liberated the will and enabled the individual to believe. Consequently, God has the right to demand spiritual fruit and faith from individuals and to justly hold accountable those who do not bear fruit. ${ }^{70}$ Arminius refers to four biblical texts to support his view that prevenient grace "is not only sufficient, but also efficacious.", "T1 The parable of the vineyard of Isaiah 5; the lament of Jesus over Jerusalem of Matthew 23:37; the rebuke against the Jews for "resisting the Holy Spirit" in Acts 7:51; and the knocking on the door in Revelation 3:21 together demonstrate three essential truths: First, God has sufficiently provided grace and the means of salvation. Second, God has some reasonable expectation that individuals will answer God's call positively. Third, God's hope is based on the fact that humans have sufficient ability, by grace, in their freedom of will to respond positively to God's offer of salvation. In short: for Arminius, the sufficiency of free will is not the result of

${ }^{69}$ Willen J. van Asselt and Paul H.A.M. Ables, "The Seventeenth Century," in Handbook of the Dutch Church, ed. Herman Selderhuis (Göttingen: Vandenhoeck \& Ruprecht, 2015), 301.

${ }^{70}$ See Perkins Exam., in Works, 3:474-481.

${ }^{71}$ Ibid., 3:479. 
some good in nature, but the result of the sufficient and efficacious work of the Holy Spirit by prevenient grace. ${ }^{72}$

Finally, Arminius understands that God's prevenient grace to call all sinful humans to salvation "denotes a total and entire act, consisting of all its parts, whether essential or integral, what parts so ever are necessary for the purpose of being enabled to answer the divine vocation."73 Therefore, in the beginning of conversion, God's call by the preaching of the Word and the influence of the Holy Spirit does not lack any essential

${ }^{72}$ For Arminius all the issue of the sufficiency and efficacy of grace connects with God's justice. God expects humans to respond positively to divine salvation because they have "sufficient power" in their "possession" to act. If God demands obedience to the law and a life of faith, it is because God has sufficiently given the power to perform such actions, otherwise God's justice would be jeopardized. Arminius assures us that "the cause why God can with justice expostulate with those who do not bear fruits is this,that "they had grace sufficient for that, but rejected it." Arminius further argues that "it seems fair to conclude that God cannot require fruits from those from whom $\mathrm{He}$, though by their own desert, has taken the power necessary to bring forth fruits . . . and if He wills to require the act, He is bound to restore the grace without which the act cannot be performed," Perkins Exam., in Works, 3:476, 478.

Explaining Matthew 23:37, Arminius introduces two distinctions in God's will. The will of "good pleasure" and the will "of sign [or revealed will]." By the will of good pleasure, Arminius argues, that the desired divine gathering of Jerusalem people "is not only sufficient, but also efficacious." Arminius concedes to Perkins that if the passage refers to the revealed will, in such a case God "helps, or is prepared to help, in order that" human beings "may be able to will ...," and God "has either given them grace sufficient, or was prepared to give it." Perkins Exam., in Works, 3:479.

Arminius, in order to support his point, finally uses the conclusions of Cardinal Bellarmine on Acts 7:51 and Revelation 3:20. The rejection of the Holy Spirit demonstrates that God's prevenient grace has previously inspired good desires in the heart; therefore, "they had sufficient grace for not resisting, nay, for assenting to the Holy Ghost." Likewise, knocking at the door signifies that "when God knocks, it is certain that man can open, and by consequence have grace sufficient." Perkins Exam., in Works, $3: 480-481$.

${ }^{73}$ Pub. Disp., XVI, in Works, 2:230. 
and necessary element to enable depraved sinners to respond freely and spiritually to faith. In other words, by prevenient grace all helpless sinners are sufficiently and efficaciously enabled to respond to the Gospel. As a result, the accidental rejection of the call to faith in Christ is not the result of any inadequacy in God's prevenient or enabling grace, but attributable to the sinful nature of individuals.

It seems safe to conclude that for Arminius prevenient grace operates unavoidably in the human heart. Humans cannot avoid being called and confronted with the law and the gospel by the preaching of the Word. They cannot avoid being internally persuaded by the actions of the Holy Spirit. They can not even stop the initial liberation of their weakened and corrupted freedom of will by the work of prevenient grace. Therefore, Arminius's conceptualization of prevenient grace is monergistic to the degree that enabling grace comes from God, makes the first move, and works sufficiently and efficaciously in the human heart creating a freed will with the capacity to respond freely to salvation.

\section{The Resistible Operation}

However, humans are able to resist the operation of prevenient grace and reject the acceptance of the Gospel. In this case, prevenient grace in Arminius's theology is resistible. For Arminius, prevenient grace does not produce actual and salvific faith unless the human will concurs with the invitation of the Holy Spirit. Arminius affirmed that God "does not make use of omnipotent and irresistible motion to generate faith in men, but of gentle persuasion adapted to move the will of man by reason of its very 
liberty; and therefore that the total cause why this man believes, and that does not, is the will of God and the free choice of man., ${ }^{, 74} \mathrm{He}$ further declared:

It is unavoidable that the free will should concur in preserving the grace bestowed, assisted, however, by subsequent grace, and it always remains in the power of the free will to reject the grace bestowed, and to refuse subsequent grace; because grace is not the omnipotent action of God, which can not be resisted by man's free will. ${ }^{75}$ It is styled "co-operating" or "concomitant," only on account of the concurrence of the human will which operating and preventing grace has elicited from the will of man. This concurrence is not denied to him to whom exciting grace is applied, unless the man offers resistance to the grace exciting. ${ }^{76}$

Arminius made clear in these affirmations that in order to produce actual faith and conversion, the free will of man, once it has received the divine prevenient grace or has been liberated by the power of prevenient grace (the unavoidable operation), must concur, agree, and cooperate with this operation of the Holy Spirit (the resistible operation). For that reason he stated that "those who are obedient to the vocation or call of God, freely yield their assent to grace; yet they are previously excited, impelled, drawn and assisted by grace; and in the very moment in which they actually assent, they possess the capability of not assenting., ${ }^{, 77}$ As will be discussed later, Arminius reduced this cooperation to acceptance or yieldedness of the free will to grace.

${ }^{74}$ Perkins Exam., in Works, 3:454. See also R. Olson, Arminian Theology, 185. Another slightly different translation says: "He has determined to save believers by grace; that is, by a mild and gentle suasion, convenient or adapted to their free-will, not by an omnipotent action or motion, which would be subject neither to their will, nor to their ability either of resistance or of will," Perkins Exam., Works-II, 3:479.

${ }^{75}$ Perkins Exam., in Works, 3:470. Emphasis added.

${ }^{76}$ Priv. Disp. LXX, in Works-II, 2:171. Emphasis added.

${ }^{77}$ Art. Article XVII, in Works, 2:722. 
Resistance not only destroys the actual production of faith, it also invalidates the actual restoration of human free will. Furthermore, for Arminius, continual resistance to God's prevenient grace inevitably results in perpetrating the sin against the Holy Spirit. Humans that "resist Divine and in fact evangelical truth, for the sake of resistance,though [they are] so overpowered with the refulgence of it, as to be rendered incapable of pleading ignorance in excuse" have rejected the "operation of the Holy Spirit ... the conviction of the truth ... and the illumination of the mind. ${ }^{, 78}$ In other words, they have effectually rejected the operation of prevenient grace. According to Arminius, this result is unexpected and accidental from the standpoint of God's purpose. He stated, "the accidental result of vocation, and that which is not of itself intended by God, is the rejection of the word of grace, the condemning of the divine counsel, the resistance offered to the Holy Spirit." ${ }^{, 79}$ God does not intend that the person reject prevenient grace. However, this is possible because the rejection results from the corruption of human will. Although the free will is now freed by the power of prevenient grace to respond positively to salvation, infirmities remain that produce and make possible the rejection of God's grace.

In emphasizing that humans have the possibility to resist the grace of God, Arminius severed himself completely from the stance of Calvin, Beza, and his colleagues at Leiden regarding how he viewed irresistible divine grace. For Arminius, prevenient grace, although it primarily operates monergistically and unavoidably in the

\footnotetext{
${ }^{78}$ Pub. Disp., VII, Works, 2:161.

${ }^{79}$ Pub. Disp., XVI, Works, 2:235.
} 
human heart, freeing the will from its corruption and weaknesses, yet grace can be resisted by the same will and so block the production of actual faith, repentance, and conversion.

In summary, the unavoidable and resistible nature of prevenient grace can be illustrated using Arminius's own writings. As regards prevenient grace, Arminius used the language of "preparation," "knocking," and "opening." He clearly stated that "grace prepares the will of man [human beings]," and subsequently, it "knocks at the doors of our hearts. ${ }^{.80}$ However, the preparation and the knocking guarantee neither the opening of the door, nor the dominion and residence of divine grace in the human heart. Nevertheless, for Arminius, the knocking at the door presupposes the existence of a liberated will capable of opening the door. He quoted Bellarmine explaining Rev. 3:20: "He who knocks at a door, certainly knowing that there is no one within who can open, knocks in vain, nay, is foolish: But be it far from us to imagine this of God: Therefore, when God knocks, it is certain that man can open.. ${ }^{, 11}$ Consequently, for Arminius, while the preparation and the knocking occurs unavoidably in the human heart, human beings can resist the operation of prevenient grace by resisting opening the door. As Stanglin and McCall put it: Prevenient grace originates "solely from God outside us (extra nos) in a monergistic way, and, to borrow imagery from Rev. 3:20, it stands at the door and knocks, ${ }^{, 82}$ but I would add that the acceptance of prevenient grace or the opening of the

${ }^{80}$ Rom. VII, in Works, 2:632.

${ }^{81}$ Perkins Exam., in Works, 3:481.

${ }^{82}$ Stanglin and McCall, Theologian of Grace, 152. 
door happens in a synergistic way, by the concurrence of the will already prepared and liberated by grace.

Before concluding our analysis of the double operation of prevenient grace, unavoidable and resistible, it is important to review an example in Arminius's writing in which this double operation is clearly evidenced.

\section{Common Grace}

Hicks argues that Arminius did not widely discuss the concept of common grace because he narrowly dedicated his attention to salvific grace. ${ }^{83}$ Certainly, Arminius did not pay close attention to and barely mentioned the concept of common grace in his theological work. However, I think that it was not a lack of interest in common grace that stopped Arminius from dedicating time and effort to this important theological category for Reformed theology. Instead, in reviewing his brief comments on common grace it becomes evident that he believed that there is no grace that is not salvific, including common grace.

As a salvific grace, I would like to suggest that, for Arminius, common grace also functions as prevenient [salvific] grace. In a series of rhetorical questions to Perkins, Arminius suggests that common grace, if used in the way Perkins proposes, must be salvific or God's justice could be questioned. ${ }^{84} \mathrm{He}$ tries to challenge Perkins's distinction

${ }^{83}$ Hicks, "Theology of Grace in . . J Jacobus Arminius," 42, n45.

${ }^{84}$ For Arminius, Perkins's idea that the rejection of common grace is a meritorious cause of damnation misrepresents the character of God. Arminius argued that if the rejection of common grace entails condemnation, the acceptance of common grace must necessarily lead to salvation. 
of common grace and salvific grace by affirming that with the "aid of common grace" if accepted by the human "free assent," the "offered blessing" of salvation could be received. ${ }^{85}$ In my opinion, this effectively renders the concept of common grace as equal to the working of prevenient grace in Arminius's theology. I suggest that it is for this reason that he did not find compelling reasons to treat common grace separately from prevenient grace.

However, the more interesting point that I want to make here in the context of the operation of grace is that Arminius in his brief and rare treatment of common grace provided a specific example of his thinking regarding the unavoidable and resistible operation of prevenient grace. Arminius speaks of this dual operation of grace not primarily to demonstrate the nature of this operation, but because he wanted to counteract Perkins's assertion that by "accepting the aid of common grace" humans "elect themselves," ${ }^{\prime 86}$ resulting in making themselves "worthy of election." This, obviously, Perkins regarded as an affront to the glory of God. Arminius responded: "Although one man, by accepting the [common] grace offered, through the aid of common grace, should make himself worthy of election ... yet it would not thence follow that elections ...

${ }^{85}$ Perkins Exam., in Works, 3:445.

${ }^{86}$ Perkins Exam., in Works, 3:444. "Etiamsi homo gratiae communis ope gratiam oblatam acceptando, se dignum electione faceret," Opera, 751. The 1853 translation renders this passage as: "Even if a man should, by accepting common grace, through the aid of common grace, makes himself worthy of Election ...., Works-II, 3:481. 
belong to man. ${ }^{, 87}$ In this context Arminius mentioned the same idea, speaking of "the grace offered to man be accepted by him by the aid of grace." ${ }^{88}$

This accurately exemplified the double operation of prevenient grace, as unavoidable and resistible, in Arminius's writings. By emphasizing the operation of prevenient grace in the acceptance of prevenient grace, Arminius not only provided a strong argument against the idea that his position caused some injury to God's monergistic working of grace. But probably intentionally rather than inadvertently, he provided a support to our reasoning that prevenient grace (resistible operation) is accepted by the operation of prevenient grace (unavoidable operation). Thus it seems safe to conclude that Arminius affirmed a double operation of grace; otherwise the only reasonable conclusion would be that if prevenient grace does not primarily work unavoidably, then the result is an illogical and never-ending anticipation of grace to grace, or put another way, the affirmation of an able and free will of the individual before the first resistible operation of prevenient grace.

It is important at this point to understand other specific ways in which this grace operates in every human heart.

The Internal Operation

As we have seen, Arminius continually underlined in his writings that prevenient grace is completely the work of the Holy Spirit on the sinner's heart. Elsewhere in his

${ }^{87}$ Perkins Exam., in Works, 3:444.

${ }^{88}$ Ibid., 3:445. 
writing Arminius called attention to the priority of the internal operation of the prevenient grace by the work of the Holy Spirit. ${ }^{89}$ For him "the principal cause is the Holy Spirit, who infuses into man ... by exciting grace, excites, moves and incites him to second acts. ${ }^{.90}$ In other words, he explains, "by the internal persuasion of the Holy Spirit" the human will is "inclined to yield assent to those truths which are preached." ${ }^{, 1}$ For Arminius, the Holy Spirit is the Author and Effector of divine prevenient grace that internally moves humans to the knowledge of God and salvation. ${ }^{92}$ He affirmed that although the efficient cause of prevenient grace is God the Father in the Son and the Son being "appointed by the Father to be the Mediator and the King of His church," it is administered "by the Spirit" and "the Holy Spirit . . . [is] Himself its Effector." ${ }^{\text {"93 }} \mathrm{He}$ further stated that the "Holy Spirit is the Author of that light by the aid of which we obtain a perception and an understanding of the divine meaning of the word." For that reason, the Holy Spirit imparts the inwardly-moving cause of God's "grace, mercy, and

${ }^{89}$ See, for example, Orat. 2., in Works, 1:356-357; Orat. 3., in Works, 1:383, 397-401; Pub. Disp., I, in Works, 2:90; Pub. Disp., in Works, 2:94; Pub. Disp., III, in Works, 2:111; Pub. Disp., VIII, in Works, 2:161; Pub. Disp., XIV, in Works, 2:213; Priv. Disp., VIII, in Works, 2:328; Perkins Exam., in Works, 3:315.

${ }^{90}$ Priv. Disp., LXXII, in Works, 2:454.

${ }^{91}$ Apology, Article VIII, in Works, 1:765; Perkins Exam., in Works-II, 3:324; see also Works 3:315.

${ }^{92}$ Priv. Disp., XLII, in Works, 2:395-396.

${ }^{93}$ Pub. Disp. XVI, in Works, 2:232. 
(philanthropy) 'love of God our Saviour toward [all]' ... by which He is inclined to relieve the misery of [sinners], and to impart unto [them] eternal felicity."${ }^{, 94}$

For Arminius, emphasizing the internal operation of prevenient grace was critical to counteract the accusations of Pelagianism against him. Arminius acknowledged that Pelagius believed only in an external operation of grace, and that he disregarded the necessary, mandatory, and precedent operation of the internal work of the Holy Spirit. Arminius said, "for Pelagius maintained, that, with the exception of the preaching of the Gospel, no internal grace [is] required to produce faith in the minds of man [human beings]. ${ }^{.95}$ Arminius would certainly agree with Pelagius that the preaching of the Word is a central part of the operation of God's prevenient grace. However, like Augustine, Arminius wanted to make clear that the preaching of the Word cannot be sufficient and effectual without the internal operation of the Holy Spirit. For him, therefore, limiting prevenient grace to the external operation of the word preached makes of prevenient grace an intellectual scriptural appeal to a capable human mind and will, destroying the necessary anticipation of God's prevenient grace as an internal and pneumatological regeneration of the human heart and will.

Arminius, however, wanted to keep the proper balance between the internal and external operation of God's prevenient grace by the work of the Holy Spirit. Although the work of the Holy Spirit is antecedent to the word preached, it is also concurrent with the annunciation of the Gospel. They cannot be separated in the experience, but the

${ }^{94}$ Pub. Disp. XVI, in Works, 2:232. 
antecedent and internal operation of the Holy Spirit must be assumed. It important now to consider Arminius's ideas regarding the external operation of prevenient grace by the instrument of the preaching of the Word of God.

\section{The External Operation}

In the working of salvation, Arminius rightly points to the centrality of the preaching of the Word. For Arminius, while revelation made possible the certainty of faith, that revelation contained in the Word is delivered to human beings by the "Word preached." ${ }^{96}$ God's revelation of his nature and actions in the Scriptures prevents [keeps] Christian religion from becoming a human fabrication. ${ }^{97}$ It also prevents [keeps] believers from wrongfully worshipping God, by establishing the scriptural reason for Christian devotion toward God and specially Christ. ${ }^{98}$ All that information contained in revelation targets the human mind and understanding because humans are "capable of Divine good" and have implanted in their hearts the desire for "the enjoyment and Infinite Good, which is God." ${ }^{99}$ It is within this dynamic of the Holy Spirit and the most usual method of the preaching of the Word that prevenient grace regenerates the believers, implanting in them faith and acceptance of the message of salvation.

${ }^{95}$ Quest. V, in Works, 2:66; se also Rom. VII., in Works, 2:630.

${ }^{96}$ Orat. 1., in Works, 1:381.

${ }^{97}$ Orat. 1., in Works, 1:380.

${ }^{98}$ Ibid., 1:380-381.

${ }^{99}$ Ibid., 1:380. 
Arminius, then, sees the dynamic of the Spirit and the Word in the preaching of the Gospel as the internal testimony of the Holy Spirit in the Word. First, the "Holy Spirit is the Author of that light by the aid of which we obtain a perception and an understanding of the divine meaning of the word, and is the Effector of that certainty by which we believe those meanings to be truly divine." ${ }^{, 100}$ From that perspective, Arminius believes that the Word of God is the instrument in the hands of the Holy Spirit to produce faith and the surrender of the human will to the will of God. He says, the "instrument is the word of God, which is comprehended in the sacred books of Scriptures; and [it is the] instrument produced and brought forward by Himself (Holy Spirit), and instructed in his truth." ${ }^{101}$ Impressively, for Arminius, the power of the word and the efficacy of the preaching of the Gospel do not reside in the Word itself, but in the action of the Holy Spirit in the production of the Word as well as in the illumination of the mind during the preaching of the Word. It is, says Arminius,

the Holy Spirit [that] gives to the Word all that force which he afterwards employs,such being the great efficacy with which it is endued and applied, that whomsoever he only counsels by his word he himself persuades by imparting Divine meaning to the Word, by enlightening the mind as with a lamp, and by inspiring and sealing it by his own immediate action. ${ }^{102}$

${ }^{100}$ Orat. 1., in Works, 1:397-398.

101 Orat. 3., in Works, 1:400.

${ }^{102}$ Ibid. 
He also states, "the assistance of the Holy Spirit, by which he assists the preaching of the gospel, [is] the organ, or instrument, by which He, the Holy Spirit, is accustomed to be efficacious in the hearts of the hearers." ${ }^{103}$

Thus, in the context of the prevenient grace of God in conversion, Arminius, understood that the actions of the Holy Spirit are not limited to the production of the content of Scripture, but they are also present in the application of the living Word in human hearts. In other words, it is by the internal operation and illumination of the Spirit and more commonly by the external preaching of the Word that the prevenient word of God brings human beings to the acceptance of the offer of salvation.

Thus, prevenient grace is especially bestowed on human hearts at the intersection of the internal work of the Holy Spirit and the hearing of the word. This means that although prevenient grace as the work of the Holy Spirit in the human minds antecedes the preaching of the Gospel, preparing the hearers to understand and receive the message of salvation, it works with further brightness and intensity at the moment of preaching and teaching the Holy Scripture. Picirilli reaches the same conclusion. He states, "apparently, this pre-regenerating grace is co-extensive with the intelligent hearing of the gospel. ${ }^{104}$ If this is the case, then the preaching acquires a central role in the salvific work of God. It is worth noting that this understanding of Arminius is consistent with Romans 10:14-17. Interestingly, Arminius quoted this passage only six times, but only

${ }^{103}$ Apology, Article VIII, in Works-II, 1:300; see also Apology, Article VIII, in Works, 1:764. Emphasis added.

${ }^{104}$ Picirilli, Grace, Faith, Free Will, 158. 
one time in connection with salvation. He used this passage, among others, to explain

vocation, that is God's calling of sinful humans. He says:

we define vocation, a gracious act of God in Christ, by which, through his word and Spirit, He calls forth sinful men, who are liable to condemnation and placed under the dominion of sin, from the condition of the animal life, and from the pollutions and corruptions of this world, (2 Tim. 1:9; Matt. 11:28; 1 Pet. 2:9, 10; Gal. 1:4; 2 Pet. 2:20; Rom. 10:13-15; 1 Pet. 3:19; Gen. 6:3,) unto "the fellowship of Jesus Christ," and of his kingdom and its benefits; that, being united unto Him as their Head, they may derive from him life, [sensum] sensation, motion, and a plenitude of every spiritual blessing, to the glory of God and their own salvation. (1 Cor. 1:9; Gal. 2:20; Eph. 1:3, 6; 2 Thess. 2:13, 14). ${ }^{105}$

It is, therefore, safe to conclude that for Arminius the calling occurs when the word of God is preached. ${ }^{106}$ The calling, as the concurrent work of the internal operation of the Holy Spirit that makes effectual the external operation of the word, is therefore an essential part of prevenient grace. In conclusion, according to Arminius, this calling is given after the capacity to respond to the Gospel has been enabled by prevenient grace.

Before concluding this section on the external operation of prevenient grace, it is important to note the part of the Church. Because of his pastoral concerns and understanding of the role of the Church, Arminius also believed that the Church as the body of Christ has a central role in the preaching of the divine truth and the calling to salvation. Certainly, Arminius carefully avoided giving to the Church such a prominent role in this work as would have placed the Church over Scripture; ${ }^{107}$ nevertheless, he understood that "if any act of the Church occurs in this place, it is that by which she is

${ }^{105}$ Pub. Disp., XVI, in Works, 2:232.

${ }^{106}$ See, Stanglin, Assurance of Salvation, 93-94.

107 Orat. 3., in Works, 1:395-396. 
occupied in the sincere preaching of this word, and by which she sedulously exercises herself in promoting its publication." ${ }^{108}$ In other words, for Arminius, while the Church preaches the Gospel, the Holy Spirit applies the Word to human hearts restoring to humans the ability to exercise his freed will and respond positively to God's actions of salvation on their behalf. It would be helpful to conclude this section with Arminius's own words. The following quotation shows how closely Arminius related the external and internal operation of God's prevenient grace: "But persuasion is managed outwardly by the preaching of the word, inwardly by the operation or rather co-operation of the Holy Spirit, tending to this end, that the word may be understood and apprehended with sure faith."109

\section{Summary and Conclusion}

In this chapter I have analyzed Arminius's theology of prevenient grace, specifically its nature, content, definition, and operation. It seems evident to me that the doctrine of prevenient grace is not a secondary idea in Arminius, but a central theme that pervades every aspect of his doctrine of grace.

Here follows a summary with some implications of the results of my study:

Arminius believed that grace is unmerited divine mercy toward miserable sinners as well as the active participation of the Holy Spirit in the life of human beings that leads them to salvation. Although grace could not be divided in its essence, it is proper to talk

\footnotetext{
108 Orat. 3., in Works, 1:400.

${ }^{109}$ Perkins Exam., in Works, 3:315.
} 
about the different effects or modes of grace. ${ }^{110}$ One of the effects of grace is prevenient grace that Arminius defined as the divine grace that by the work of the Holy Spirit restores human freedom of will to empower human beings to accept the offer of salvation and the invitation to believe and have faith in Christ as Savior and Lord.

Prevenient grace is essential for Arminius because he understood that humans are in a condition of total depravity, and thus unable to perform truly spiritual good. Corrupted human nature is incapable of hearing and receiving the Gospel of salvation and humans are incapable of subjecting their wills and lives to the will of God. Arminius believed that in this desperate condition the solution was not an overpowering manifestation of divine grace that irresistibly leads humans to a relationship with God. Rather, for him prevenient grace restores humans' abilities to will to receive salvation, not as impassible rocks or pieces of wood, but as willing participants in accepting Christ's work done in their favor.

This idea of Arminius's had major implications for the Protestant Reformation in general and the Reformed tradition in particular. Arminius wanted to correct the Reformed tradition's understanding of the role of human beings in salvation. He wanted to preserve the monergistic and sovereign view of God's work in redemption and at the same time to recognize the biblical claim that humans participate in the acceptance of the divine invitation to salvation. Using the concept of prevenient grace helped him to

${ }^{110}$ See also Junius Conf., in Works, 3:134, 168. 
maintain the monergistic movement of God that always comes before human actions and the synergistic participation of individuals in the acceptance of salvation.

For that reason, according to Arminius, prevenient grace operates in the human heart primarily as a monergistic movement of God toward humans. Prevenient grace works unavoidably in individuals to restore and liberate their freedom of will from their clouded and corrupted nature. This results in a freed and restored will able to evaluate and accept the divine offer of salvation. Obviously, humans have no say in this movement as it is entirely a divine and free gift of God. In this way, the concept of prevenient grace helped Arminius to embrace the Reformed understanding of the monergistic and sovereign work of God in salvation, and at the same time to destroy the Pelagian and Semi-Pelagian (or neo-Pelagian) understanding of an unblemished will capable of responding to or initiating salvation.

However, Arminius did not want to limit his understanding of the operation of prevenient grace to an unavoidable movement. He added a new layer of understanding to the idea by affirming that prevenient grace could be resisted by the freed will of human beings. In this case, Arminius understood a resistible operation of God's prevenient grace. Because prevenient grace has anticipated human will and freed it from the slavery of sin and corruption, humans are able to reject the divine gentle suasion or invitation to accept the offer of salvation. On the one hand, Arminius made clear that acceptance of prevenient grace is possible because of the working of prevenient grace that has freed or liberated the human will. This obviously, for Arminius, does not mean that human will has a meritorious participation in salvation. On the other hand, Arminius understood that rejection is an accidental action due to the corruption of human will. In this way, 
Arminius corrected the Reformed understanding of an irresistible working of grace without human concurrence. In sum, because of prevenient grace Arminius could assert consistently that "salvation belongs [only] to the Lord" (Jon. 2:9), while at the same time giving a role to human will in the acceptance of salvation.

Having paid attention to the operation of prevenient grace in relation to the Godhuman relationship, this chapter also paid attention to the operation of prevenient grace in relation to the Agent-instrument. The operational agent of prevenient grace is the Holy Spirit, while the instrument of the Word of God is the preaching of the Church. By prevenient grace the Holy Spirit works internally in the human heart preparing, liberating, and empowering the human will and mind to understand and accept Christ and salvation. Prevenient grace, for Arminius, is highly pneumatological. The role of the Holy Spirit in a personal, internal, and gentle relationship with individuals characterizes every aspect of Arminius's understanding of prevenient grace.

In the working of prevenient grace, the Holy Spirit does not limit his work to the internal empowerment of the will and the illumination of the mind. He employs the external instrument of the Holy Scripture by the preaching of the word. While the Church and his ministers preach the Gospel, the Holy Spirit concurs with the word that illuminates the soul and effects the divine calling of salvation. I do not think that Arminius limited the working of prevenient grace to the moment that the preaching and teaching of the word is taking place, as Picirilli claims. However, I agree with Picirilli that at the intersection of the preaching of the Gospel and the internal operation of the Holy Spirit, the prevenient grace of God works in a more radical and effective way in the calling to salvation. Thus, it is safe to conclude that for Arminius, the preaching of the 
word is the usual external instrument of prevenient grace that invites human beings into a salvific relationship with God.

In the next chapter I turn to explore carefully and deeply the question of the universality of prevenient grace in Arminius's theology: Does Arminius support prevenient grace as a universal work of the Holy Spirit that is sufficient and efficacious in all individuals? 


\section{CHAPTER 5}

\section{PREVENIENT GRACE IN ARMINIUS' THEOLOGY II}

\section{Introduction}

The universality of prevenient grace is one of the most controversial aspects of this concept in Arminius's theology, besides the resistible nature of its operation. In the previous chapter, I have suggested a solution to the concept of resistible prevenient grace. The aim of this chapter is explore the universal work of prevenient grace in Arminius's writings.

The chapter explores the language of universality in Arminius's writings and its relation to the concept of prevenient grace. After a complete analysis of the issue of universality of prevenient grace, the challenge of Arminius's concept of divine foreknowledge is that ultimately it renders God a determinist. I will try to offer a possible solution to demonstrate that Arminius maintained a theological tension between God's foreknowledge and the universality of prevenient grace. The chapter finishes by describing the spiritual result of the work of prevenient grace and by proposing that the concept of prevenient grace is the organizing principle of Arminius's soteriological ideas by which he reconciles and holds together all the essential elements of Arminius's concept of salvation. 


\section{Prevenient Grace: The Universal Work of the Holy Spirit}

As we have seen, some Arminian theologians have argued that prevenient grace in Arminius's theology is circumscribed to the locations where the gospel is preached. ${ }^{1}$ Yet it seems to me more appropriate to conclude that although Arminius viewed prevenient grace as being closely connected with the preaching of the Word, he also understood prevenient grace as the universal work of the Holy Spirit that is extended to all human beings throughout the world. Not only is the universality of prevenient grace evident in the way that Arminius used the theological tradition of the Christian Church, but an analysis of Arminius's understanding of the amplitude of the atonement, the divine covenant, the vocation to salvation, the universal experience of the human struggle between the Spirit and the flesh described in Romans 7, and the special operations of the Holy Spirit also confirms a broadly universal language in Arminius writings.

Since Arminius does not deal directly with the universality of prevenient grace as a separate doctrine, it will be necessary to explore his theological constructions of the previously mentioned concepts in order to establish that Arminius actually defended a universal view of the doctrine of prevenient grace. Therefore, this section explores the language of the universality of prevenient grace, giving special attention to those theological topics that relate to the subject.

\footnotetext{
${ }^{1}$ Olson, Arminian Theology, 167; Eaton, 72.
} 


\section{Universal Language of Prevenient Grace in}

the Christian Theological Tradition

Arminius referred to patristic literature to support his belief that the calling to salvation is extended to all human beings.

For example, Arminius quoted Prosper of Aquitaine to emphasize that "on all men has always been bestowed some measure of heavenly doctrine" and "this aid [prevenient grace] is afforded to all men, by innumerable methods both secret and manifest." ${ }^{2}$ Arminius frequently quoted Prosper to support his view on grace, free will, the universality of Christ's sacrifice, the cleansing of original sin at baptism, and the possibility that believers could fall from grace and regeneration. ${ }^{3}$ By quoting the expression "this aid is afforded to all men," Arminius most likely concurred with Prosper that the divine aid of prevenient grace is universally and equally given to all human

2 Apology, Article XXVIII, in Works 2:54. After quoting Prosper, Arminius finished his argument stating: "I do not produce these passages, as if I thought that either my brethren or I must abide by the sentiments of the Fathers, but only for the purpose of removing from myself the crime of Pelagianism in this matter." It seems to me proper to conclude that if Arminius quouted this particular portion of Prosper's work in order to avoid any improper identification of his ideas with the heresy of Pelagius, then, he agreed with Prosper in this particular aspect. The quotation from Prosper that appears above is a reference from the book The Vocation of the Gentiles. This is one of the disputed works of Prosper. However, modern scholars, like Arminius in his time, believe that the work is an authentic contribution of Prosper. See Alexander Y. Hwang, Intrepid Lover of Perfect Grace: The Life and Thought of Prosper of Aquitaine (Washington D.C.: The Catholic University of America Press, 2009), 17-20. Shelton also quotes this sentence from Arminius as evidence that prevenient grace is granted to "all people." However, Shelton fails to disclose that the affirmation was not from Arminius himself, but a reference taken from Prosper. See Shelton, 118.

${ }^{3}$ See, Apology, Articles I, II, XII, XIII, XIV, in Works, 1:738-770. 
beings. ${ }^{4}$ Although Prosper evidently experienced a theological development between his first theological work, De Providentia Dei, and his later contributions after his encounter with Augustine, the idea of universal grace and salvation was a common element in all his works. ${ }^{5}$

Indeed, Prosper was useful for Arminius because Prosper's language, in that context, evidently points to prevenient grace — that divine grace "persuading us by exhortation, admonishing us by examples, affrighting us by dangers, exciting us by miracles, by giving understanding, by inspiring counsel, and by illuminating the heart itself, and imbuing it with the affections of faith." " In Arminius's writings, these images of divine salvific actions denote the initial work of conversion impelled by the prevenient grace of God. Although this is not the only evidence of the universality of prevenient grace in Arminius's writings, it is an indication of Arminius's understanding of God's allencompassing love for all sinners.

Arminius frequently drew upon Augustine's writings because he considered the church father an authority in theological and biblical matters. Indeed, Augustine is by far the most cited authority of antiquity in Arminius's writings. However, as Aza Goudriann points out, Arminius's reading of Augustine was "selective"; he used Augustine to

\footnotetext{
${ }^{4}$ Hwang states that for Prosper "the light of God's illumination and offer of salvation are given to all, equally," see Hwang, Intrepid Lover of Perfect Grace, 62.

${ }^{5}$ Prosper of Aquitaine, De Providentia Dei, Text, translation, and commentary by Miroslav Marcovich (Leiden, the Netherlands: Brill, 1989), x.

${ }^{6}$ Apology, Article XXVIII, in Works 2:54.
} 
support his own theological viewpoints and conceptualizations. ${ }^{7}$ With reference to the universality of prevenient grace, Arminius concurred with Augustine's conclusions in $O n$ Nature and Grace that God "is everywhere present, who, by many methods through the creature that is subservient to Him as his Lord, can call him who is averse . . . can exhort a diligent man ... can aid him who strives, and can lend an attentive ear to him who deprecates." ${ }^{\prime 8}$ The expression that captured Arminius's imagination was "God is everywhere present." Since negation of the universal presence of God not only would undermine God's sovereignty but also God's providence and redemptive work, for Arminius, because God is everywhere, His salvific actions are also everywhere present. In this case, Augustine's language regarding calling, aiding, and exhorting refer to the concept of prevenient grace as the beginning of redemption.

\section{God's Character: Love and Justice}

Arminius desired above all to preserve the biblical picture of God's character. He believed that the concept of unconditional election betrayed God's character of love and justice. ${ }^{9}$ For that reason, the love and justice of God demand universal reach for divine prevenient grace.

${ }^{7}$ Goudriann, “'Augustine Asleep' or 'Augustine Awake'? Jacobus Arminius' Reception of Augustine," 63.

${ }^{8}$ Apology, Article XXVIII, in Works, 2:54.

${ }^{9}$ For Arminius the Supralapsarian doctrine of predestination could not demonstrate God's mercy and justice, because the act is in itself "contrary to his mercy and justice." See Decl. Sent., in Works, 1:623-625. 
First, the justice or righteousness of God demands that all God's creatures be given an opportunity for salvation, otherwise, "God cannot [be] just." Consequently, God's justice demands universal prevenient grace in Arminius's system of theology. God is, therefore, compelled by his justice and character to offer a salvific opportunity and help for all unmerited sinners. As Den Boer puts it, "God's justice 'obligates' God . . . to distribute prevenient grace universally." ${ }^{, 10}$ For Arminius, this is because one main characteristic of God's justice, together with truth and fidelity, is sincerity. ${ }^{11}$ This means that there is no duplicity in God's deeds, purpose, and words. Therefore, when the Scriptures say that God "invites" all to salvation, God truly intends to save all, and provides the necessary means of redemption for all human beings. As Stanglin and McCall explain, "when God ... invites or warns ..., he certainly means it and he says it with utter sincerity." 12

Thus, rearticulating one of Arminius's questions regarding God's justice, it is possible to ask: Will the justice of God ordain the eternal perdition of a human being who never received the opportunity to accept the offer of salvation? Arminius would most probably respond in the negative. ${ }^{13}$ For that reason, Arminius believed that the prevenient grace of God gives all humans the opportunity to receive salvation. This is because God's

${ }^{10}$ Den Boer, God's Twofold Love, $181 \mathrm{n} 14$.

${ }^{11}$ Priv. Disp., XXI, in Works, 2:351.

${ }^{12}$ Stanglin and McCall, Theologian of Grace, 78. See also, Jerry L. Walls, Does God Love Everyone? The Heart of What is Wrong with Christianity (Eugene, OR: Cascade, 2016), 57-59.

${ }^{13}$ Priv. Disp., XXI, in Works, 2:355. 
justice always communicates all good "according to regeneration" in a "just ... right ... and equal" way, unfailingly giving "to every one his own." 14

In the same manner, for Arminius, God's love for his creatures demands prevenient grace as a divine act of salvation. Scripture reveals the love of God and Christ towards human beings expressed in benevolent, salvific, and beneficial actions. ${ }^{15}$ Communication of good in creation and salvation proceeds from "divine love and goodness" resulting in actions of "grace, benignity, and mercy."16 Although God's love for justice overrides His love for creatures, for Arminius God has demonstrated a great deal of love for human beings and their happiness. ${ }^{17}$ Therefore, Arminius considered the twofold love of God as equal by affirming that God made the greatest demonstration of love, at the same time towards miserable sinners and towards divine justice, by offering his Son as mediator, legal satisfaction, and sacrificial substitute. ${ }^{18}$ By offering his life, the eternal Son of God becomes the "Son of his love" in whom all God's sinful creatures encounter mercy and grace. ${ }^{19}$

${ }^{14}$ Priv. Disp., XXI, in Works, 2:350.

15 Orat. 3., in Works, 1:383.

${ }^{16}$ Pub. Disp., IV, in Works, 2:130-133; Priv. Disp., XX, in Works, 2:347-349.

${ }^{17}$ See Pub. Disp., XIV, in Works, 2:221-222; Art. II, 2:707. Elsewhere Arminius affirms that God loves primarily himself and the good of justice, and secondarily, the creature and her felicity.

${ }^{18}$ Pub. Disp., XIV, in Works, 2:221.

${ }^{19}$ Elsewhere Arminius affirms that reception of divine love, prevenient grace, and all other salvific benefits exist in Christ and are mediated only through Christ; see for instance, Priv. Disp., XL, in Works, 2:392. He states: "For the love with which God loves 
Then, as God does with justice, so too God equally extends his love to all of his creatures. This love first touches sinful individuals, calling them into a new relationship with the divine reality. Arminius admitted, however, that the "love of God" is not equal "in all respects towards all men," but at the same time, he negates that "there is so much difference. ${ }^{, 20}$ In this context Arminius equated God's love with prevenient grace, affirming that, because of the Gospel, God has decided for all eternity "to treat ... all men, fallen in Adam, according to this grace. ${ }^{21}$ With this assertion, Arminius refuted the inference that God's love "towards all men in general" undermines the intensity of God's special love for the elected ones. ${ }^{22}$ While election displays a special divine love toward those who respond to the offer of salvation, prevenient grace demonstrates the universal love of God toward all created individuals without favoritism.

In this context, Arminius wisely connected prevenient grace, as the preparation for regeneration, with God's character of love and justice. For him, the Scriptures make clear that God tirelessly works for the salvation of all wretched humans, thus showing His patience, long-suffering, and mercy. Exodus 33:19 and 34:6-7 became sufficient evidence of this reality. According to Arminius, these characteristics of God's character are actualized in prevenient grace's actions toward sinners, described in Isaiah 5:4,

men absolutely to salvation, and according to which $\mathrm{He}$ absolutely intends to bestow on them eternal life,- - this love [non est] has no existence except in Jesus Christ, the Son of his love."

\footnotetext{
${ }^{20}$ Perkins Exam., in Works, 3:330.

${ }^{21}$ Ibid.

${ }^{22}$ Perkins Exam., in Works, 3:337.
} 
Romans 2:4, and Romans 9:22. Indeed, in these actions God satisfies his love for justice and love for creatures by "admonish[ing], invit[ing], and incit[ing] [them] to faith and conversion. ${ }^{, 23}$

\section{The Extent of the Atonement}

In contrast to many Arminians, Arminius maintained a satisfaction and penal substitution view of the atonement. For him, Christ died to "pay the price of redemption for the sins and the captivity of the human race. ${ }^{24}$ Similar to Anselm of Canterbury (1033-1109), Arminius believed that God rightly required "satisfaction from the sinner for the injuries with He has sustained. ${ }^{, 25}$ However, unlike Anselm but similar to his Reformed contemporaries, Arminius viewed God's justice rather than God's honor as the entity aggrieved by the sin of human beings. ${ }^{26}$ Consequently, Christ took "upon himself,

${ }^{23}$ Perkins Exam., in Works, 3:310.

${ }^{24}$ Orat. 4., in Works, 1:416. John M. Hicks, "The Righteousness of Saving Faith: Arminian Versus Remonstrant Grace," Evangelical Journal, vol. 9, no 1 (Spring, 1991): 28. Hicks says that "Arminius's doctrine of atonement is fundamentally the same as that of the Reformers except he gives an explicit universal potential to the benefits of Christ's death."

${ }^{25}$ Ibid., Works, 1:412. For a further account of Arminius's view of the extent of the atonement see the recent and massive work on the history of the doctrine of the atonement by David L. Allen, The Extent of the Atonement: A Historical and Critical Review (Nashville, TN: B\&H Academic, 2016), 135-149.

${ }^{26}$ Ibid., Works, 1:413-415. See the dialogue between God's Mercy and God's Justice in order to find a solution in favor of sinful humanity. The solution was provided by God's Wisdom, which suggested an expiatory sacrifice "to appease Justice, and open such a way for Mercy." It should be offered by the same person as both a priest and a victim. Such a person should be taken from among men because the victim must be a human victim. Jesus Christ, out of love for humans, became both the priest and the victim as "the Son of God and of man." 
on our account, the discharge of those difficult and arduous duties which were full of pain, trouble, and misery. ${ }^{27}$ Christ offered himself on the cross as a sacrifice that provided "the price for sins by suffering the punishment due to them. ${ }^{, 28}$ Evidently, Arminius entirely agreed with his colleagues about the nature of Christ's atonement.

The disagreement between Arminius and Reformed theology concerns the extent of the atonement. The crucial question was: Did Jesus die for everyone? Absolutely, said Arminius. He advocated for a universal view of Christ's atonement. However, Arminius invoked the established sufficient/efficient formula to explain the scope of Christ's death.

He summarized his view, explaining:

The $\lambda$ vitpov or "price" of the death of Christ is affirmed to be universal in its sufficiency, but particular in its efficacy; that is, sufficient for redemption of the whole world, and for the expiation of all sins; but that its efficacy does not appertain to all universally; which efficacy consists in its actual application by faith and the sacraments of regeneration. ${ }^{29}$

It seems crucial here to pay close attention to the ideas contained in this declaration. First, what did Arminius propose to teach regarding the universality of the atonement? And second, what are the reasons why Arminius limited the application and efficacy of the atonement?

Arminius interpreted the universal passages of the New Testament theologically. He undoubtedly encountered in the affirmations of the universal passages evidences for God's universal prevenient grace and love. Arminius divided the universal passages into

${ }^{27}$ Orat. 4., Works, 1:416; Perkins Exam., in Works, 3:328.

${ }^{28}$ Orat. 4., in Works, 1:419.

${ }^{29}$ Perkins Exam., in Works, 3:324. 
two well-defined groups. First, he explored the passages that refer to the death of Christ and contain the expression "world" and "whole world." Second, he examined those passages that include the word "all" as a clear reference to the whole of humanity.

First, the death of Christ was universally intended for all. Arminius concluded that the expression "world" and "whole world" in the New Testament universalizes the divine salvific plan. Arminius referred specifically to Johannine literature like John 1:29; 3:16; 6:51; 4:42; and 1 John 2:2; 4:14. He also quoted 2 Corinthians 5:19, "God was in Christ reconciling the world unto Himself." 30 He argued against Perkins that the word "world" in all these passages refers to "the whole body of humanity" and not only to the elect. ${ }^{31}$ Affirming the contrary, like Perkins does, and thus particularizing the scope of the word "world," betrays not only the biblical truth about the extent of the atonement, but more precisely the scriptural affirmations on the nature of atonement.

Likewise, Arminius interpreted those passages that speak about the sacrifice of Christ being offered for "all" as intended to influence the human race universally. Passages like Hebrews 2:9 and 1 Timothy 4:10 testify regarding the salvific actions of God in Christ in favor of all human beings. ${ }^{32}$ Interestingly, Arminius connected these "all" passages with several biblical texts that speak of Christ as mediator between God and men and Christ dying for the ungodly (for instance 1 Timothy 2:5; Romans 5:6, 8).

${ }^{30}$ Apology, Article XII, in Works, 2:9-10; Perkins Exam., in Works, 3:329.

${ }^{31}$ Perkins Exam., in Works, 3:329. From these passages he asserted that "in the word 'world,' all men, in general, are the be understood."

${ }^{32}$ Perkins Exam., in Works, 3:329. 
His argument is that just as all sinners participate in the sin and nature of Adam, similarly, all sinners participate in the salvific actions of Christ's death. He explained that "the case of the whole human race is one; all were equally conceived and born in sins, and children of wrath. ${ }^{, 33}$ Logically, for Arminius the premise that there is no distinction at the level of the natural and sinful life of humanity means that there is no distinction at the level of the divine salvific solution for the problem. For that reason, "Christ took upon Him the human nature common to all" representing the "person of all men." ${ }^{34}$ In other words, the satisfaction and penal substitution nature of the atonement together guarantee the universal scope of the expiatory sacrifice.

In addition to the biblical record, Arminius also believed that the theological tradition of Christianity sided in his favor. He quoted Prosper of Aquitaine affirming that "the blood of Jesus Christ is the price paid for the whole world ... and the redemption of the whole world. ${ }^{, 35}$ In this manner, Arminius argued that the potency, sufficiency, and magnitude of the blood of Christ as the price for sin extended to all humanity.

It is important to remark here that for Arminius no further condition should be added to the sufficiency of Christ's death. His opponents agreed with Arminius that Christ's sacrifice was sufficient for the sins of the whole world. However, they added a condition that for Arminius completely destroyed the universal language of the

${ }^{33}$ Perkins Exam., in Works, 3:329.

${ }^{34}$ Ibid., Works, 3:328.

${ }^{35}$ Ibid., Works, 3:325. Arminius explains in his Examination of Perkins's Pamphlet that "Scripture in many places most plainly teaches that Christ died 'for all,' and "for the life of the world."” 
atonement in Scripture. For instance, Arminius contended that Perkins's affirmation that the atonement was sufficient for the whole world ("provided that God had willed it to be offered for the sins of the whole world") $)^{36}$ undermined sufficiency in connection with Christ's death. For Arminius, the sufficiency of Christ's death is actualized in the fact that payment and substitution have been made for all.

Second, Arminius evidently accepted a distinction between the sufficiency and the efficacy of the atonement. For him, the merits of Christ's death are to be applied only to the believers by faith. However, in Arminius's writings this particular application refers to actual salvation. Beyond the obvious difference (in which for Calvin the atonement is particularly applied to those who have been sovereignly elected by God, and for Arminius the application depends on the human acceptance of Christ's sacrifice), for Arminius, the universal efficacy of the cross is materialized in the universal application of prevenient grace. In other words, the universal nature of prevenient grace is guaranteed by the universal extension of the atonement that at the same time is grounded in God's justice and love. As Gary L. Shultz, Jr. puts it, "prevenient grace itself is a result of Christ's universal atonement." ${ }^{, 37}$

${ }^{36}$ Ibid., Works, 3:324. The current discussion on the sufficiency of Christ's death within the Reformed tradition seems to follow the same pattern of thought as that of Perkins against which Arminius reacted. For instance, Roger Nicole, "The Case for Divine Atonement," Bulletin of the Evangelical Theological Society, vol.10, no. 4 (1967): 199. Nicole says that the sacrifice of Christ was "amply sufficient to redeem all mankind," adding, counterfactually, that it would be the case "if [God] had so intended."

${ }^{37}$ Gary L. Shultz, Jr. A Multi-Intentioned View of the Extent of the Atonement (Eugene, OR: Wipf \& Stock, 2013), 31. 
Although Arminius did not explicitly state this conclusion, a logical result of his theology is that the merits of Christ are actualized universally in the working of prevenient grace in the human heart. It seems safe to conclude that in Arminius's theology the universal extent of the atonement necessarily demands the universal scope of prevenient grace. In other words, the divine working of God in Christ on the cross provided the legal ground of prevenient grace for all individuals.

\section{The Universality of the Divine-Human Covenant}

Arminius has not been considered a covenant theologian. However, he used the concept of covenant widely to express his understanding of salvation. Related to our study, the covenantal theology of Arminius anticipates a covenantal prevenient grace that extends to all humanity. ${ }^{38}$

Arminius understood that covenant is God's mode of relationship not only with humanity but also within the Trinity. He approached the biblical covenants from a synergistic view of human-divine relationship. Indeed, such an approach helped Arminius to protect the glory and character of God as well as to stress the liberty and human responsibility in both the fall into sin and the work of salvation. Humans, in their pristine

${ }^{38}$ Most of Arminius's theology of covenant can be found disseminated throughout his writings. However, there are specific works in which he focused more specifically on the concept of covenant. Among these writings are his orations; Orat. 1., in Works, 1:321-347; Orat. 4., in Works, 1:402-433. Equally important are his disputations; Priv. Disp., XXIX, in Works, 2:369-370; Priv. Disp., XXX, in Works, 2:371-373; and Priv. Disp., XXIXX, in Works, 389-391. For specific studies on Arminius's covenantal theology, see Richard A. Muller, "The Federal Motif in Seventeenth-Century Arminian Theology," Nederlandsch Archief Voor Kerkgeschiedenis 62/1 (1982):102-122; Raymond A. Blacketer, "Arminius's Concept of Covenant," 193220. 
nature, as rational, intelligent, free, social, and spiritual/moral beings were capable of maintaining a willing, healthy, and free covenantal relationship with their Creator.

However, sin stopped humans from continuing to partake of a covenantal relation with God. It is in the context of the new sinful nature and miserable condition of human beings that Arminius introduced the covenant of grace describing the merciful intervention of God on behalf of humanity.

Most miserable, and deserving of the deepest commiseration, was the condition of mankind in that state of their affairs, - if this declaration be a true one, "Happy is the people whose God is the Lord!" (Psalm 144:15.) And this inevitable misery would have rested upon Adam and his race for ever, had not Jehovah, full of mercy and commiseration, deigned to receive them into favor, and resolved to enter into another covenant with the same parties; not according to that which they had transgressed, and which was then become obsolete and had been abolished; but into a new covenant of grace. ${ }^{39}$

For Arminius, therefore, divine grace toward sinful individuals becomes the essential characteristic of the covenant of grace. It is in this context of grace and covenant that Arminius stated clearly the universal nature of prevenient grace. Thanks to God's covenant with Christ, the covenant of redemption, ${ }^{40}$ "God has taken the whole human race into the grace of reconciliation, and has entered into a covenant of grace with Adam, and with the whole of his posterity in him: In which he promises the remission of all sins. ${ }^{~} 41$

${ }^{39}$ Orat. 4., in Works, 1:410.

${ }^{40}$ Arminius believed that the covenant of redemption between God and the Son is the foundation of the covenant of grace.

${ }^{41}$ Apology, Article XIII, XIV, in Works, 2:11. 
Thus, for Arminius, salvific grace or prevenient grace is available to everyone. He openly affirmed that in Adam God has entered into covenant with the "whole human race" or the whole of Adam's posterity; thus, divine redemption and reconciliation are universally offered. So, he advocated for a covenantal theology that it is not restricted to the elect. While Reformed theology collocated the covenant of grace in the context of predestination or election, Arminius collocated the covenant in the context of the universality of prevenient grace or the divine call to salvation to all human beings. It is the answer of the soul to the prevenient grace of God that leads to spiritual regeneration and participation in the covenant relationship of grace.

\section{The Extent of the Battle between the Spirit} and the Flesh in Romans 7

Arminius's interpretation of Romans 7 is one of the most persuasive arguments in favor of the universality of prevenient grace. For Arminius, the battle between the Spirit and the Flesh happens in every single human being, including those who are not yet regenerated. On the one hand, Arminius understood that categorizing the individual in the spiritual struggle of Romans 7 as unregenerate created serious theological problems. One problem was that this interpretation aroused the suspicion of Pelagianism, to which Arminius quickly responded by qualifying the unregenerate person. However, on the other hand, Arminius believed that categorizing as regenerate the individual of Romans 7 represented a departure from the biblical teaching of the passages as well as from the traditional interpretation of the Church. Unlike his contemporaries, he interpreted the miserable person as unregenerate. 
It seems to me that Arminius defended only two specific spiritual stages in the experience of human beings: the regenerate and the unregenerate. However, he divided the unregenerate human beings into two different grades or steps; unregenerate individuals under the influence of grace and unregenerate individuals in their natural depravity. ${ }^{42}$ Here, I will discuss only the two kinds of unregenerate persons according to Arminius. First, humans exist in total depravity "devoid of regeneration" as well as "those things which usually precede regeneration." 43 This kind of unregenerate person, for Arminius, are "those who have felt no $[$ actum $]$ motion of the regenerating Spirit, or of its tendency for regeneration." 44 In this case, individuals are devoid of a knowledge of the law and strangers to the influence of the Holy Spirit, and therefore totally dead "in transgressions and sin" (Eph 2:1). Interestingly, in this group Arminius also included those who had rejected the calling to salvation or had turned away from the way of redemption. $^{45}$

${ }^{42}$ For Arminius's definition of a regenerate human under grace, see, Rom. VII., in Works, 2:497.

${ }^{43}$ Rom. VII., in Works, 2:489.

${ }^{44}$ Apology, Article XVI, in Works, 2:17. See also, Rom. VII., in Works, 2:498. He clearly defined this kind of unregenerate: "An unregenerate man is, - not only [one] who is entirely blind, ignorant of the will of God, knowingly and willingly contaminating himself by sins without any remorse of conscience, affected with no sense of the wrath of God, terrified with no compunctions [or] visits of conscience, not oppressed with the burden of sin, and inflamed with no desire of deliverance."

${ }^{45}$ Rom. VII., in Works, 2:498. Arminius also defined a second category of unregenerate human being: "it is also he who knows the will of God but does it not, who is acquainted with the way of righteousness but departs from it." 
The second kind of unregenerate persons are those unconverted human beings affected in their minds by the requirements of the law, living under the law, and also under the influence of those things preceding regeneration, but who are not yet transformed by God's grace. Arminius identified this second group as the humans engaged in a spiritual struggle between the Spirit and the Flesh in Romans $7 .{ }^{46}$ These unregenerate persons are "those who feel [actus] those motions of the Holy Spirit which belong either to preparation or to the very essence of regeneration, but who are not yet regenerated. ${ }^{47}$ They are also under the conviction of sin by the law. Here Arminius finds the proper function of the law advanced by the Epistle of Romans, as convincing humans about sin and leading them to Christ for mercy, grace, and salvation. For Arminius, humans in this condition do not necessarily occupy a middle ground or "intermediate stage" between been regenerate and unregenerate, as Olson suggests ${ }^{48}$ but rather,

${ }^{46}$ Rom. VII., in Works, 2:490.

${ }^{47}$ Apology., Article XVI, in Works, 2:17. He further explains: "Let the word 'unregenerate' be taken for a man who [jam renascitur] is now in the act of the new birth, though he be not yet actually born again," Ibid., Works, 2:18. About these individuals Arminius further says he or she is one: "Who is affected with a painful sense of sin, is oppressed with its burden, and who sorrows after a godly sort;- - who knows that righteousness cannot be acquired by the law; - and who is therefore compelled to flee to Christ," "Dissertation on the True and Genuine Meaning of the Seventh Chapter of the Epistle to the Romans," Rom. VII., in Works, 2:498. It is important to mention that Arminius sometimes identifies this unregenerate person under the law as not having the "light of the Holy Spirit." This seems to be somewhat inconsistent with his analysis of Romans 7 and the unregenerate individual in connection with the Holy Spirit. However, he is evidently referring not to the light that initially illuminates the soul to call people to salvation, that is, prevenient grace, but he refers to the light of the Holy Spirit that has already resulted in regeneration "by the Spirit of Christ," Rom. VII., in Works, 2:608.

${ }^{48}$ Olson, Arminian Theology, 164-165. Indeed, Arminius rejected the notion of an "intermediate state" or different "degrees" of regeneration stating that "liberty 
although unregenerate and unconverted they are in the process of regeneration. For Arminius, it is better to speak of "a grade or step from the one [state] to the other" than to present three states of humans in relation to salvation. However, Arminius did not see this matter as being of critical importance because Augustine, Bucer, Musculus, and the Scriptures sometimes present three and even four conditions of human beings. ${ }^{49}$

In this context, one thing seems to me evident in Arminius's understanding of the "wretched man" in Romans 7. The "wretched man" represents an unregenerate individual, but one that is under the work of God's prevenient grace by both the conviction of the law and the influence of the Holy Spirit. Indeed, Arminius never separates the operation of the law from the operation of the Holy Spirit. He clearly stated that anything good in this step of the unregenerate individual is not "from the store-house of nature, but it deduces [to] them from the operation of the Spirit, who employs the preaching of the law and blesses it." ${ }^{, 50}$ The question at this point is: Do all human beings universally experience this struggle between the Spirit and the Flesh as unregenerate individuals? According to Arminius, humans can universally show a spiritual struggle between the Spirit and the Flesh as described in Romans 7 as a result of the working of the Holy Spirit and the conviction of the law. Arminius came to demonstrate that reality

[regeneration] cannot consist in even the smallest portion of servitude or captivity" because it is impossible to say that "this man is partly free from sin, and partly its slave and captive; but a necessity would arise for the existence of a third thing from these two, which might obtain the name of 'a medium between the extremes,' belonging neither to this nor to that," Rom. VII., in Works, 2:573, 591.

${ }^{49}$ Rom. VII., in Works, 2:591-592, 628.

${ }^{50}$ Ibid., 2:632. 
by appealing to several biblical texts and authorities within the Reformed tradition like Calvin and Beza.

As part of his understanding of the role of the law in Romans 7 in the life of the unregenerate individual, Arminius also believed that all humans have at least a basic knowledge of the requirements of the law. After dividing the function of the law, first, into an instrument of condemnation, and second, into a document of instruction, guidance, and conviction, Arminius claimed that "all sinners universally are said to be under it." ${ }^{51}$ However, since in the first function of the law the universality is unqualified, Arminius admitted that in the second, sinners are under the law to "different degrees and orders." 52 This basically means that the "efficacy, guidance, power, and exercises" of the operation of the law appear in different form and force in different individuals. Arminius seems to refer to the different influences exercised by the written law of Scripture and the written law of the natural world in their heart.

Indeed, in this context, he mentioned the distinction of Romans 2:13-18 between Gentiles and Jews in their relation to the law. ${ }^{53}$ In any case, Arminius wanted to make clear that the presence of the law, Scriptural or natural, universally produces a struggle in the human heart between the Spirit and the Flesh. For him, not only the apostolic testimony of Romans 2 points to this reality, but also several other passages, such as Luke 12:47; 1 Corinthians 7:1; 13:2, and 2 Peter 2:21, which speak of unregenerate

${ }^{51}$ Rom. VII., in Works, 2:492-493.

${ }^{52}$ Ibid.

${ }^{53}$ Rom. VII., in Works, 2:494. 
individuals as having a knowledge, albeit limited, of the law. ${ }^{54}$ In order to sustain his argument, Arminius referred to theological authorities, in this case Peter Martyr, the influential Italian Reformed theologian. Martyr affirmed:

We do not deny that there is occasionally some contest of this kind in unregenerate man; not because their minds are not carnal and inclined to vicious pursuits, but because in them are still engraven the laws of nature, and because in them shines some illumination of the Spirit of God. ${ }^{55}$

In my view, therefore, because Arminius elsewhere relates the influence of the law to the concept of prevenient grace, and because he universalized the function of the law, resulting in a painful contest between the Spirit and the Flesh; consequently, he necessarily understood the working of the Holy Spirit in the administration of prevenient grace as a universal reality in the experience of all human beings.

Indeed Arminius made clear this reality in his interpretation of Romans 7. He claimed that the influence of the Holy Spirit manifestly works in the life of unregenerate individuals. In my understanding, Arminius interprets this working of the Holy Spirit to be closely related to the operation of prevenient grace. This seems obvious because prevenient grace language is present everywhere. He says that the unregenerate in this case is in "the commencing act" or initial "operation of the Holy Spirit.." ${ }^{, 6}$ Likewise, he says that "grace prepares the will of man" and also "knocks at the door of our hearts.,

${ }^{54}$ Rom. VII., in Works, 2:521.

${ }^{55}$ Ibid., 2:519.

${ }^{56}$ Ibid., 2:494.

${ }^{57}$ Ibid., 2:632. 
Significantly, Arminius presents supporting biblical references like Hebrew 6:4-5;

Matthew 7:22; 11:28; Revelation 3:17, 18; and Galatians 2:16. ${ }^{58}$ In relation to Matthew 11:28, Arminius speaks of calling, an integral part of prevenient grace, as the necessary preceding work to justification and sanctification. Later, in his consideration of Romans $7: 15$, he concludes that "the contest between the mind (incited by the law and the Spirit) and the flesh ... must of necessity be placed among the beginnings and the precursors of regeneration. ${ }^{, 59}$ Using this evidence, Clarke claims that for Arminius not only the influence of the Holy Spirit is present in the unregenerate, but that they can even "show a good deal of the workings of the Holy Spirit." ${ }^{, 60}$

Because everywhere else Arminius used language to include all sinners universally, it is difficult to believe that in this case he is thinking of a particular application of prevenient grace. Indeed, Arminius openly denied the reality of a human being existing only in "the flesh" because the imperative of the law and the illumination of the Holy Spirit works in all, though in different degrees. ${ }^{61}$ For this reason, he carefully distinguished between the "indwelling of the Holy Spirit" in the human heart and the "preparation by the Spirit" of the human heart. At this point, he made the clearest reference to prevenient grace, highlighting that it is "one thing to feel or perceive some

${ }^{58}$ Rom. VII., in Works, 2:494-495.

${ }^{59}$ Ibid., 2:521.

${ }^{60}$ F. Stuart Clarke, “Arminius's Use of Ramism in His Interpretation of Romans 7 and 9," in Interpreting the Bible: Historical and Theological Studies in Honour of David F. Wright, ed. A. N. S. Lane (Leicester, England: Apollos, 1997), 137.

${ }^{61}$ Rom. VII., in Works, 2:530. 
effect of preparing grace; and it is another to be under grace, or to be ruled, led and influenced by grace. $" 62$

Before closing our discussion on this topic, it seems important to underline that for Arminius, this human being of Romans 7 is different from the human being in Galatians 5:16-18. The spiritual struggle of Romans 7 is experienced in the unconverted life, but in an individual under the influence of prevenient grace. Therefore, this human is frequently conquered by the power of sin. Differently, the individual in Galatians 5:1618 is under the dominion of grace and the power of the Holy Spirit, therefore, God "[prevents] sin from having dominion over [them], and [hinders them] from fulfilling the lust of the flesh." ${ }^{63}$ Arminius believed in the possibility of a complete victory over sin, although he did not assert the possibility of attaining perfection [in the sense of being beyond the possibility of falling from grace]. For that reason, Arminius asked a question of great importance: "After the Holy Spirit has commenced the mortification and death of sin, what is the act of the same Spirit respecting sin?." ${ }^{64} \mathrm{He}$ answered: "Undoubtedly it is the persecution of the remains of sin, that He may subdue and extinguish them until they no longer exist." 65 There is no middle ground for Arminius, because "liberty cannot [exist] with even the smallest portion of servitude or captivity." 66 This, Arminius argued,

${ }^{62}$ Rom. VII., in Works, 2:544.

${ }^{63}$ Ibid., 2:571.

${ }^{64}$ Ibid., 2:572-573.

${ }^{65}$ Ibid.

${ }^{66}$ Rom. VII., in Works, 2:573. 
is not the case of the human of Romans 7 who, if he followed the reasoning of his contemporaries, would be "partly free" and "partly a slave." Galatians 5, therefore, provided Arminius with the argument to demonstrate that the struggle continues after regeneration, but that the Holy Spirit, this time, is the victor. For that reason, he maintained that "all who have been grafted into Christ by true faith, having been made partakers of his life-giving Spirit, possess sufficient spiritual strength to fight against Satan, sin, the world, and their own flesh — and to gain victory over these enemies—yet none of this at any time without the perpetual assistance of the grace of the same Holy Spirit. ${ }^{, 67}$

However, Arminius insisted on the possibility that the once-converted person can lapse in the unsurrendered state which would then be characterized by the struggle of Romans 7. For that reason, he suggested the necessity of daily renewal, spiritual rebirth, or conversion in order for a person to surrender completely to God. He stated:

I confess indeed, that it may be correctly said, 'the new man is daily renewed more and more;'- both because it is needful that this newness, which has been produced in a [human being] by the act of the regenerating Spirit, should increase and be augmented day by day; - and because the remains of the old man ought by degrees to be taken away and weakened more and more. ${ }^{68}$

Thus, for Arminius, the struggle of the converted lies in attaining this daily victory, which the individual can do by keeping aliving their relationship with the Holy

${ }^{67}$ Arminius, Declaration of Sentiments, in Gunter, Arminius and His Declaration, 141; Decl. Sent., in Works, 1:664.

${ }^{68}$ Rom. VII., in Works, 2:550. He also said that "this work of regeneration and illumination is not completed in one moment; but that it is advanced and promoted, froom [die] time to time, by daily increase," Pub. disp., XI, in Works, 2:195. 
Spirit. The struggle of the unconverted, but under the working of prevenient grace, continues until the individual accepts the God's grace and salvation. I think that this is a key difference to keep in mind in Arminius's understanding of Romans 7 and Galatians

5.

In summary, when interpreting Romans 7, Arminius continually made clear that the Pauline image of a wretched human being refers to an unregenerate individual, but one that it is awakened by the influence of prevenient grace and the actions of the Holy Spirit beginning with the law and following with the Gospel. He stated:

these things are attributed to the unregenerate, without any injury to grace and the Holy Spirit; because they are believed to be, in those in whom they are found, through the operation of grace of the Holy Spirit. For there are certain acts which precede conversion, and they proceed from the Holy Spirit who prepares the will. ${ }^{69}$

It is important to analyze the scope of the calling to salvation in connection with the concept of prevenient grace, and it is to this what we now turn.

The Universality of Vocation

Divine vocation, as we have seen, is closely related to prevenient grace in Arminius's theology. Here, I will pay close attention to the calling to salvation as an integral part of the process of prevenient grace. Thus, I briefly discuss Arminius's understanding of the universality of the divine calling to salvation. Indeed, he believed that in Christ God calls all individuals to salvation.

${ }^{69}$ Rom. VII., in Works, 2:542. 
Arminius in his concluding arguments against Perkins clearly stated that "all men are called with some calling [by some vocation]. ${ }^{, 70} \mathrm{He}$ listed some forms of calling such as the "witness of God ... the truth . . . and the writing of the law in their minds.","11 Arminius evidently had prevenient grace in mind because he asserted that this calling is not immediately salvific, implying that a human response to God's call is necessary. A universal calling to salvation, therefore, does not imply for Arminius that all humans will actually be saved. But it does imply that God really comes to every human being with an offer to participate in his program of redemption. Universal prevenient grace is engraved in the calling as the knocking on the door.

\section{The Extent of the Special Operation of the Holy Spirit}

Arminius certainly related prevenient grace to the preaching of the Word.

However, he likewise did not want to limit the operation of the Holy Spirit only to those places where the Word is preached. This is obviously crucial for Arminius's understanding of the universality of grace, for otherwise divine prevenient grace effectively would be restricted to within the boundaries of Christian preaching and ministry. The language of universality in connection with the heathen or unevangelized nations and individuals is certainly a difficult topic, so a Christian thinker must proceed with caution in this respect. It seems to me that Arminius considered that good works are present in the life of the heathen thanks to the influence of God's prevenient grace by the

${ }^{70}$ Perkins Exam., in Works, 3:484.

${ }^{71}$ Ibid. 
work of the Holy Spirit. Here, Arminius carefully related the prevenient work of grace to the concept of natural theology.

Arminius denied that a true good work could be possible without the work of the Holy Spirit and the knowledge of God. He does not consider it possible to act rightly and honestly only by "nature." In other words, for Arminius, human nature deprived of grace and of the Spirit of God only "tends downward to those things that are earthly." ${ }^{, 72}$ Yet at the same time, Arminius openly stated that Paul acknowledges that the heathens "have a true knowledge of God. ${ }^{, 73}$ How are both possible?

According to Arminius, any evidence of good works "agreeable to God" demands the existence of a true knowledge of God. It is evident that even the Gentiles are capable of doing some portion of good; therefore, they have a true knowledge of God. But Arminius went further to affirm that a true knowledge of God is only possible by the assistance of grace and the Holy Spirit. A comprehensive reading of Arminius's disputations on the topic shows that Arminius rejected the idea that humans come into the world with an innate knowledge of God and moral life. Such knowledge, present even in heathens, is the result of the general revelation of God informed by grace and the work of the Holy Spirit. For Arminius, God "did not leave Himself without witness" (Acts 14:17); therefore, to all humans God has "revealed some truth concerning His power and goodness; and has preserved the law engraved on their minds." ${ }^{.74}$ This understanding is

${ }^{72}$ Apology., Article XV, in Works, 2:15.

${ }^{73}$ Ibid.

${ }^{74}$ Perkins Exam., in Works, 3:483. 
really singular in Arminius's theology. It is possible, then, to conclude that Arminius effectively believed that the Holy Spirit was working within the heathen even though the preaching of the word was not present. ${ }^{75}$ For Arminius, his opponents not only deny this but contradict themselves by affirming both that the heathens have no knowledge of God and that they are able to do good works. For this reason, Arminius sarcastically said that his opponents are the true Pelagians and the hunters caught in their own snare.

From this conclusion arises a critical question: Did Arminius believe this special work of the Spirit to be salvific or only another common activity within the providential work of God? Arminius's intention points to the salvific nature of this work of the Spirit. This seems to be evident because he consciously related Romans 1 and 2 to the history of the conversions of Cornelius and Lydia in Acts 10 and 16. For Arminius, all human beings by the general revelation of God are able to have true knowledge of God. This true knowledge of God informs them not only about the existence of God, but also about the

\footnotetext{
${ }^{75}$ It is possible to see Arminius's logic by constructing two syllogisms from his discussion:

Major premise: Good works demand a true knowledge of God.

Minor premise: Gentiles are capable of doing some good.

Conclusion: Therefore, gentiles have a true knowledge of God.

Major premise: True knowledge of God demands grace and the work of the Holy Spirit.

Minor premise: Gentiles have a true knowledge of God.

Conclusion: Therefore, the grace and the work of the Holy Spirit is present within the gentiles.
} 
"knowledge of Truth," His eternal power and Godhead, and their duty to glorify God. Unrighteousness, then, is only possible because "they knew God." Consequently, they are “deprived of all excuse." In Arminius's evaluation this is only possible because God's grace precedes their accountability. For him, the story of Cornelius and Lydia demonstrates that the preventing work of the Holy Spirit is working in the human hearts long before they hear the message of the Gospel. ${ }^{76}$

At this point, Arminius is careful to clarify that natural theology is not sufficient for salvation unless the work of the Holy Spirit is adjoined to it. His reading of Romans 1 and 2 makes clear this reality. Responding to his opponents Arminius asked: "What is the nature of this expression, 'If they do those things which the powers of nature enable them to perform?", ${ }^{\prime 77}$ I provide Arminius's answer in its entirety here to make clear Arminius's thought.

Is "nature," when entirely destitute of grace and of the Spirit of God, furnished with the knowledge of that Truth which is said to be "help in unrighteousness," by the knowledge of "that which may be known of God, even his eternal power and Godhead," which may instigate man to glorify God, and which deprives him of all excuses, if he does not glorify God as he knows Him? I do not think, that such properties as these can, without falsehood and injury to Divine Grace, be ascribed to "nature," which, when destitute of grace and of the Spirit of God, tends directly downward to those things that are earthly.",78

For Arminius then, nature is only able to lead humans to glorify God as a result of grace and of the Holy Spirit in the heart of those who may not have the opportunity to

\footnotetext{
${ }^{76}$ Apology., Article XV, in Works, 2:15-16.

${ }^{77}$ Apology., Article XV, Works, 2:15.

${ }^{78}$ Ibid. Emphasis added.
} 
hear the Gospel. John Platt accurately understands Arminius's meaning in this respect, asserting that "Arminius takes the important step of assigning the knowledge of God obtainable from natural order to the realm, not of nature, by of grace.. ${ }^{, 79}$

Nevertheless, Arminius continues to be cautious, asserting that this work of the Holy Spirit is preparatory and does not necessarily lead to actual salvation in every instance and that the preaching of the Word was certainly critical and the ordinary means for the work of conversion. For him, the stories of Cornelius, Lydia, the Bereans, and others exemplify that the preaching of the Gospel is the "ordinary means" of actual conversion. ${ }^{80}$ More precisely, Arminius quotes Acts 19:9-10 to establish that "God sends the external preaching of his word to nations, when it is his good pleasure for the great numbers of them to be converted. ${ }^{, 81}$ For Arminius, in conversion both realities-the internal operation of the Holy Spirit and the preaching of the word — must be maintained. Nevertheless, Arminius did not completely close the door to an "extraordinary" work of the Spirit, one separated from the Word. He supported a common saying of his time that "the Holy Spirit is not so bound himself to this method [preaching] as to be unable to operate in an extraordinary way, without the intervention of human aid.

${ }^{79}$ John Platt, Reformed Thought and Scholasticism: The Arguments for the Existence of God in Dutch Theology, 1575-1650 (Leiden, The Netherlands: Brill, 1982), 180.

${ }^{80}$ Apology., Article XVIII, Works, 2:21.

${ }^{81}$ Ibid.

${ }^{82}$ Ibid. 
Finally, in this context Arminius also corrected Scholastic conclusions regarding the nature of conversion and grace by specifically pointing to prevenient grace. Different than for the medieval theologians like Biel and others, for Arminius prevenient grace is the work of the Holy Spirit and is not integrated with nature. He radically rejected the Scholastic maxim "God will do that which is in Him, for the man who does what is in himself," unless prevenient grace is added to the formula. ${ }^{83}$ In his corrected paraphrase Arminius says, "God will bestow more grace upon that man who does what is in him by the power of Divine Grace which is already granted to him.. ${ }^{, 4}$ Similarly, in answering question number four of the Synod, Arminius affirmed that good works are made and "rewarded in a moral view, not so much through the powers of nature, as by some operation in them [unbelievers] of the Holy Spirit." ${ }^{85}$ Obviously, it is not because humans do what is in them by the power of human nature or will, but because they accept prevenient grace that humans receive further divine grace leading them to salvation.

It seems proper, then, to conclude that, for Arminius, natural theology remains an essential aspect of the special operation of prevenient grace by the work of the Holy

${ }^{83}$ Fesko defends the opinion that this idea in Arminius's writings clearly demonstrates Arminius's acceptance of the medieval facientibus formula: "Facientibus quod in se est Deus non denegat gratian ('Do what is in you and God will not deny his grace')." See, Fesko, “Arminius on Facientus," 350. Like Muller before him, Fesko believes that Arminius's likely sources are medieval theologians like Gabriel Biel, Peter Lombard, and Thomas Aquinas. However, Arminius demonstrated that even when nature is involved in the preparation for salvation and conversion, the working grace of God and of the Holy Spirit is to be presupposed. Prevenient grace is not an integral part of nature, not even the testimony of nature is out of nature, much less so prevenient grace.

${ }^{84}$ Apology., Article XV, in Works, 2:16. Emphasis added.

${ }^{85}$ Quest., in Works, 2:66. 
Spirit. Obviously, Arminius's theological language in this respect is universal and not limited to where the gospel is preached. However, Arminius believed that the final step in this process would typically be the preaching of the Word.

The remaining question in connection with Arminius's understanding regarding the nature of the good works of the unevangelized is: How different is Arminius from other Reformed theologians of his time? Although, this dissertation does not look to validate or compare Arminius's conceptualizations with other Reformed theologians, it seems of benefit to briefly summarize the position of the Reformed tradition on this concept.

John Calvin, as Herman Kuiper says, believed in a universal or "general common grace" that sustains the world and even results in the performing of good works by the ungodly ${ }^{86}$ These good works result from the reality of the imago dei present in humanity, the testimony of nature, and even the work of divine grace to maintain order, peace, and harmony in society. However, for Calvin, this work of grace is non-salvific in nature. He clearly says: "In every age there have been some who, under the guidance of nature, were all their lives devoted to virtue. It is of no consequence, that many blots may be detected in their conducts; by the mere study of virtue, they evinced that there was somewhat of purity in their nature." ${ }^{, 87}$ Calvin continues by affirming that "some have not only excelled in illustrious deeds, but conducted themselves most honorably through the whole course

\footnotetext{
${ }^{86}$ Herman Kuiper, Calvin on Common Grace (Goes, the Netherlands: Oosterbaan \& Le Cointre, 1928), 181.

${ }^{87}$ Calvin, Intitutes, II.3.3, 4.
} 
of their lives." $" 88$ This is the result of grace, but a kind of grace that does not "purify," but only maintains under "internal restraint" the evilness of human nature. ${ }^{89}$ In sum, for Calvin, the actions of the Holy Spirit in the heart of unevangelized individuals are only for the preservation of society, having a restraining effect on their corrupted nature.

Calvin's concept of this providential but non-salvific grace, called common grace, became the commonplace understanding of the Reformed tradition. For instance, Martyr also argued that human beings are able to perform good and virtuous works because the imago dei is present in the soul and the testimony of nature. However, as John P. Donnelly explains, Martyr believes that all these good acts of the ungodly are contaminated by sin, and consequently, they are unpleasing to God. ${ }^{90}$ In sum, the Reformed theologians recurred to the concept of general or common grace as a necessary category to explain the good works and the presence of some kind of divine grace among the pagans and unevangelized. However, this divine activity does not intend to provide salvific grace.

It seems to me, that Arminius's conceptualization regarding the actions of the Holy Spirit among the pagans, different from his Reformed contemporaries, could be understood as salvific actions of God's prevenient grace. For Arminius, this work of the

${ }^{88}$ Calvin, Intitutes, II.3.3, 4.

${ }^{89}$ Ibid. Calvin finalizes his argument stating that this grace is not "a special grace," therefore, "we cannot set any value on anything that seems praiseworthy in ungodly men."

${ }^{90}$ John Patrick Donnelly, S. J., Calvinism and Scholasticism in Vermigli's Doctrine of Man and Grace (Leiden, the Netherlands: Brill, 1976), 110, 113. 
Holy Spirit and the consequent virtuous works of the unevangelized are salvific in the sense that God's prevenient grace has liberated and prepared the will to hear and respond to salvation. It could also be understood as salvific in the sense that although this manifestation of prevenient grace does not necessarily and finally results in actual conversion, it does prepare the will for the manifestation of the Word of God. As I said previously, Arminius expected that at some point in their lives, these unevangelized individuals would come in contact with the preaching of the Word. However, it is not only at that precise moment that God's salvific actions by prevenient grace are working in their favor. Previously, their wills have been informed and liberated by the internal work of the Holy Spirit. Certainly, Arminius did not completely clarify all the implications of his views. For instance, he did not respond to the question of whether, if the heathens never come in contact with the preaching of the Word and the Gospel their acceptance of prevenient grace through the internal illumination of the Holy Spirit, the testimony of nature, and the consequent performing of moral works is sufficient for eternal salvation? Arminius's conceptualization seems to indicate that the answer ordinarily is no. This is evident because, for instance, he avoids controversy by distancing himself from, although not openly condemning, the position of Zwingli regarding the salvation of the pious or virtuous pagans like "Socrates, Aristides, and others in similar circumstances," ${ }^{, 91}$ However, it seems to me that because Arminius understood common grace as equal with prevenient grace, then the revelation that involves sufficient

${ }^{91}$ Apology, Article XVIII, in Works, 2:21. 
accountability to result in eternal damnation must, if accepted, also constitute sufficient revelation to enable eternal salvation. Indeed, contrary to Martyr, Arminius does say that the good works of the heathen are pleasing to God because they are the resulting work of the Holy Spirit's influence in the human heart.

Thus it could be said at this point that for Arminius, prevenient grace that is also salvific grace comes to all people by one means or the other; the 'ordinary' means is by the Holy Spirit and the preaching of the Gospel; the 'extraordinary' means is by the Spirit without the Word, which would most often be by the Spirit through the witness of God in nature. ${ }^{92}$ In any case, the implications of Arminius's conceptualization on the universality of grace in the context of the special work of the Holy Spirit among the heathens is that all people without exception have sufficient grace, and their will has been sufficiently liberated, to provide the opportunity to respond to God's salvific invitation. Nevertheless, Arminius made it clear that the special revelation through the Word and the Gospel is so much more effective that exposure to the Word leads many more people to salvation than does the Holy Spirit and the testimony of God in nature, apart from the Word. Thus, it is safe to conclude that prevenient grace as the initial work of God in liberating the will is universally and effectively manifested to all human beings.

${ }^{92}$ It should be noted, however, that the distinction that Arminius presented between the "ordinary" work of the preaching of the Word, and the "extraordinary" work of the Holy Spirit through natural revelation as means of salvation relates to actual conversion and not necessarily with the initial working of prevenient grace, see Apology., Article XVIII, in Works, 2:20-22. Arminius clearly regarded the natural revelation more highly than did his contemporaries. For instance, see the distinctions between the "ingrafted word" of God "universally" disclosed "to the mind of men" and the "outward word" in Scripture, Priv. Disp. V, in Works 2:322-324. 


\section{Prevenient Grace and Divine Foreknowledge and Election}

A challenge to the universality of prevenient grace in Arminius's theology is his own concept of divine foreknowledge. One could argue that Arminius's ideas on God's knowledge betray his conclusion about the universal efficacy of prevenient grace. As we will see, in my understanding Arminius's conceptualization of God's knowledge in general and God's foreknowledge in particular seems to imply at least some kind of determinism. If God in the actualization of his foreknowledge regarding the contingent choices of individuals grants prevenient grace only to those who he foreknows will positively accept or respond to it, then, the real universality of prevenient grace and the actual decision of human will are jeopardized.

But before pursuing this discussion, a brief but precise comment concerning Arminius's understanding of foreknowledge and election may prove instructive.

Divine foreknowledge and election relate closely to grace, especially prevenient grace, in the theology of Arminius. From my readings on the concept of divine foreknowledge, I distinguish between historical foreknowledge, sovereign foreknowledge, and ontological or metaphysical foreknowledge. By historical foreknowledge, I mean God's knowledge of future events based on His knowledge of the becoming of history. ${ }^{93}$ Sovereign foreknowledge is the knowledge that God has of future events based on His eternal sovereign decision about what the future will be like. In this

${ }^{93}$ For instance, see Fernando Canale, Basic Elements of Christian Theology: Scripture Replacing Tradition (Berrien Springs, MI: Fernando Canale, 2005), 104-111; 120-131. Some scholars identified this concept of divine foreknowledge as "a 
case, God's foreknowledge is based on God's will. ${ }^{94}$ Arminius did not have either a historical nor a sovereign view of God's foreknowledge. Instead, Arminius had an ontological view of God's foreknowledge. God knows the future looking into himself, that it is, looking into his own essence. ${ }^{95}$ Consequently, the cause of God's knowledge for Arminius is God's will, only in the sense that His will decides to create a particular reality already present in his essence or nature. It seems useful at this point to explain briefly Arminius's views on God's knowledge before considering the relationship between God's foreknowledge and prevenient grace.

Arminius's concept of God's knowledge is solidly constructed upon a faithful acceptance of the classical view of God's nature and attributes. ${ }^{96}$ Timelessness, eternity, impassibility, and immutability are essential for Arminius's conceptualization of God's understanding. Because God is impassible and immutable, his nature is both "devoid of all [passionis] suffering or feeling" and "void of all changes;-—of being transferred from place to place, because it is itself its own end and good, and because it is immense; - of

perceptualist model of divine cognition.” See McGregor, Luis de Molina, 97.

${ }^{94}$ For instances see John M. Frame, Systematic Theology: An Introduction to Christian Belief (Phillipsburg, NJ: P\&R, 2013), 306, 308-310; Michael Horton, The Christian Faith, 263; Michael Bird, Evangelical Theology: A Biblical and Systematic Introduction (Grand Rapids, MI: Zondervan, 2013), 518-519.

${ }^{95}$ For instance, one modern theologian that equates God's foreknowledge with God's essence is Norman L. Geisler, Systematic Theology in One Volume (Minneapolis, MN: Bethany, 2011), 497-498.

${ }^{96}$ Arminius affirmed the classical view of God. God is one, simple, self-existence (aseity), timeless, eternal, infinite, immutable, impassible, incorruptible, omnipotent, omnipresent, and omniscient. He also enlisted all the communicable attributes of God's character like love, goodness, and beauty. See Priv. Disp. XX, in Works, 2:347-350. 
generation and corruption; - of alteration; - of increase and decrease." ${ }^{.97}$ This reality of God's nature directly shapes God's life, knowledge, and will. Arminius assured his readers that God "knows all things from eternity, nothing [de novo] recently." 98 Obviously, this divine knowledge of future reality is complete, perfect, immutable, and certain.

Arminius divided God's knowledge into three essential orders or logical moments: God's natural necessary knowledge (scientia naturalis), God's foreknowledge (scientia libera), and God's middle knowledge (scientia media).${ }^{99}$ These logical moments of God's knowledge could have become familiar to Arminius by the influence of Louis de Molina (1535-1600), a Spanish Jesuit scholar. In order to guide the discussion of Arminius's understanding and modification of these logical moments of God's knowledge, it seems useful to know how some Molinist scholars have diagrammed these logical orders:

Moment 1: God's scientia naturalis of everything that could be.

Moment 2: God's scientia media of everything that would be.

Interval of the free act of God's will: Divine wisdom chooses to create a particular world from all the possibilities.

${ }^{97}$ Pub. Disp. IV, in Works, 2:117.

${ }^{98}$ Ibid.,, Works, 2:121.

${ }^{99}$ Pub. Disp. IV, in Works, 2:123-124. Arminius used different terminology to refer to these logical moments of God's knowledge: sciencia naturalis: natural, necessary, infinite, indeterminate, practical, of simple intelligence; sciencia libera: vision, free, definite, determinate, and foreknowledge; and sciencia media. 
Moment 3: God's scientia libera of everything that will be and happen. ${ }^{100}$

Before considering Arminius's view, it is important to understand that this logical order occurs in the mind of God, not in a historical sequence. In other words, all divine knowledge is prior to creation and the historical continuum. Arminius, like most theologians of his time, understood that God's knowledge is a timeless "simple and infinite intuition" in the life of God. ${ }^{101}$ MacGregor calls this concept of knowledge a "conceptualist model of divine cognition.",102

According to Arminius, God's natural and necessary knowledge is the main source of all other kinds of God's knowledge. In other words, divine foreknowledge and middle knowledge are deeply rooted in the natural and necessary knowledge of God. These three logical moments of God's knowledge are faculties of God's life. For Arminius, there is no distinction between God's life and God's essence. ${ }^{103}$ Thus, as a result of his natural and necessary knowledge, God knows himself "entirely and adequately" before knowing all reality. It is by knowing his own reality or being [essence] that God is able to know "other things [and all things possible] entirely and

100 This is a modified diagram from Kenneth Keathley, Salvation and Sovereignty: A Molinist Approach (Nashville, TN: B\&H Academic, 2010), 17; see also the popular Molinist booklet by William Lane Craig, What Does God Know? Reconciling Divine Foreknowledge and Human Freedom (Norcross, GA.: Ravi Zacharias International Ministries, 2002).

${ }^{101}$ Priv. Disp., XVII, in Works, 2:341.

${ }^{102}$ MacGregor, Luis de Molina, 97.

${ }^{103}$ See, Pub. Disp., IV, in Works, 2:119. He clearly stated that "the Life of God is his Essence itself, and his very Being." 
excellently, as they are in Himself and in his Understanding [in the mind of God]. ${ }^{, 104}$ In this manner, God knows minutely not only all possibilities but also all reality. Again, the knowledge of Himself, other things, and other beings is an eternal, immeasurable, single and undivided act, certain, infallibly aware of all future realities, even future contingencies, without the influence of any external cause. ${ }^{105}$ It is in this context that we need to understand Arminius's view of foreknowledge and middle knowledge as ontologically rooted in God's essence.

Arminius defined foreknowledge as God's understanding of all realities and entities "which are, will be, or have been."106 Regarding foreknowledge, Arminius explained that "a thing does not come to pass because it has been foreknown or foretold [by divine will]; but it is foreknown and foretold because it is yet to come to pass." In other words, "things [non sint] do not exist because God knows them [futuras] as about to come into existence, but that he knows future things because they are future."107 That is to say that for Arminius, foreknowledge is "[in the divine mind] posterior in nature and order to the thing that is future." ${ }^{\prime 108}$ Arminius means that in a logical progression in the

${ }^{104}$ Pub. Disp., IV, in Works, 2:121-122.

${ }^{105}$ See, Priv. disp., XVIII, in Works, 2:341. Arminius affirms: "The understanding of God is certain and infallible: So that He sees certainly and infallibly even things future and contingent; whether He sees them in their causes, or in themselves. But this infallibility depends on the infinity of the essence of God, and not on his unchangeable will."

${ }^{106}$ Pub. Disp., IV, in Works, 2:123.

${ }^{107}$ Ibid., Works, 2:124.

${ }^{108}$ Priv. Disp., XXVIII, in Works, 2:368. 
mind of God, not a historical or chronological progression, future things [reality or created reality] are prior to God's foreknowledge of them. God knows future reality because such a reality is in His own nature before He knows it. ${ }^{109}$ In his argument with Gomarus, Arminius explains this when he says that God "by His wisdom knows all things, and by the same wisdom sets His will to determine what things are to be created." ${ }^{110}$ It seems obvious that for Arminius once that God had decided to create a specific world or reality, the future is completely closed. Consequently, contingent choices are contingent only in the mind of God, not in history. This, it seems to me, raises the question of determinism in Arminius's theology. For instance, if at some moment in eternity God knows that an individual will accept or will not accept prevenient grace in her life, then the question that this raises is: Will that specific individual be truly free to do otherwise in respect to what she will do at the future time.?

Arminius continues arguing that created reality (as logical, not as historical actualization) precedes God's foreknowledge. In other words, God's foreknowledge is similar to "human (after)knowledge." 111 This is possible because in God's natural knowledge all possible future realities already exist, and from this knowledge God decided to create a specific world that accorded with his wisdom. Consequently, as I

${ }^{109}$ Priv. Disp., XVII, in Works, 2:341. He clearly states that God's knowledge is "by simple and infinite intuition, according to succession of order, and not of time."

${ }^{110}$ Gomarus Exam., in Works, 3:556.

${ }^{111}$ See the discussion regarding God's knowledge in Reformation Arminianism in Steven M. Studebaker, "The Mode of Divine Knowledge in Reformation Arminianism and Open Theism" JETS 47/3 (September 2004): 469-480. See also, Robert E. Picirilli, "Foreknowledge, Freedom, and the Future," JETS 43/2 (June 2000): 263. 
previously affirmed, although in one sense the cause of God's foreknowledge is still God's will, in another sense the real and natural cause of God's foreknowledge is his very nature, internal being, or reality. ${ }^{112}$ Arminius is evidently counteracting his Reformed contemporaries notion of the sovereign or predestinarian foreknowledge, or more precisely, foreordination.

Therefore for Arminius, strictly speaking the cause of God's free knowledge is God's knowledge of his own Essence and Infinity. He explained that "every kind of God's knowledge is necessary: For the free understanding of God [foreknowledge] does not arise $\left[\begin{array}{ll}e x & e o\end{array}\right]$ from this circumstance, that a free act of his will exhibits or offers an object to the understanding; but when any object whatsoever [posito] is laid down, the

${ }^{112}$ Similar to Arminius's later position, Franciscus Junius experienced exuberant joy when he discovered that God's foreknowledge does not equate with God's will, but with God's nature. He described this joy in very descriptive language: "Foreknowledge could not be sure and infallible, unless it rested on an immutable cause. But he denied that God's will was that immutable cause; it was something else, namely the divine nature, which precedes that will. I was as thrilled with this as if I had found a great treasure, which I value so cheaply in comparison with certain knowledge of those things about which I have been anxiously worrying for seven years now, that I prefer true knowledge which satisfies my mind on those articles about providence and predestination (so may God love me) than the riches of Croesus and Midas, indeed the treasures of the whole world," cited in Clarke, 24. Fernando Canale affirms that, for Arminius, God's nature or reality is the basis of foreknowledge. Canale is right in seeing God's nature as an integral component of the basis of God's foreknowledge. However, he fails to acknowledge that, for Arminius, God also exercises his volition, informed by his own divine essence or being, to bring forth His creative decrees resulting in an unique feasible world. This means, that according to Arminius, God's will is also an integral basis of the divine foreknowledge. See Canale, 115-116. 
Divine understanding knows it necessarily on account of the infinity of its own Essence." $" 113$

Likewise, it seems to me, that middle knowledge of future contingencies is rooted in God's natural knowledge. Similar to Louis de Molina, ${ }^{114}$ Arminius argued that using his middle knowledge God knows "anything [si hoc sit] if it be or exist" or "if this happen, that will take place." ${ }^{, 15}$ More precisely, middle knowledge mediates "in things which depend on the liberty of created [arbitrii] choice or pleasure." ${ }^{, 16}$ Using this middle knowledge, therefore, God knows everything that would happen and under what circumstances a specific and free act of created beings will take place or be actualized. Therefore, God knows counterfactual truth of future contingencies. For instance, God

${ }^{113}$ Pub. Disp., IV, in Works, 2:124. Emphasis added.

${ }^{114}$ There is disagreement among scholars about whether Arminius was a committed or only an incidental Molinist. Kirk R. MacGregor suggests a distinction between Arminius and Molina's systems and use of middle knowledge. He explains that middle knowledge needs careful definition in order to identify Arminius as a Molinist. He says that "if the theory simply denotes the doctrine of God's prevolitional counterfactual knowledge, then Arminius's system is undoubtedly based upon scientia media. On the other hand, if the theory is taken as shorthand for the full range of divine cognitive activities posited by Molina from God's counterfactual knowledge to his creative decree, then Arminius's system is not grounded in scientia media, as it deviates quite sharply from Molina's depiction of God's complete and unlimited deliberation," see A MolinistAnabaptist Systematic Theology (Lanham, MD: University Press of America, 2007), 6465; 69-72. Obviously, there are other scholars who believe that Arminius's and Molina's views of middle knowledge are the same. See Barry E. Bryant, "Molina, Arminius, Plaifere, Goad, and Wesley on Human Free-Will, Divine Omniscience, and Middle Knowledge," Wesleyan Theological Journal, vol. 27 (1992): 93-103; and Dekker, "Was Arminius a Molinist?," 337-352.

${ }^{115}$ Pub. Disp., IV, Works, 2:123; Priv. Disp., XVIII, in Works, 2:342.

${ }^{116}$ Pub. Disp., IV, in Works, 2:124; Priv. Disp., XVIII, in Works, 2:342. 
knew under which conditions Judas either would or would not use his freedom of will to betray Jesus. Likewise, God knows under which circumstances an individual either would or would not use his freedom of will to accept God's offer of salvation. Dekker affirms that for Molina and Arminius, God actually created the specific circumstances, and that "by creating the circumstances, God has genuine control over what people [with] genuinely free will do." ${ }^{, 117}$ If Dekker is correct, the implication of this for my argument is that once God's volition has decided to create one specific world from all the possibilities already known by His natural knowledge and all the feasible decisions of human free will by His middle knowledge, the divine foreknowledge is rendered deterministic in the system of Molina and Arminius. However, I think that for Arminius, although God really created the specific circumstances, humans could do otherwise in the same set of circumstances. This means that for Arminius, through middle knowledge, God merely knows the free exercise of the human that will result in a specific set of circumstances.

All these orders of God's knowledge in relation to prevenient grace could be better understood if they were discussed in relation to God's will. For Arminius, these orders of God's knowledge either precede or follow the free act of divine will. While divine sciencia naturalis and scientia media precede the free act of God's will, sciencia

${ }^{117}$ Dekker, "Was Arminius a Molinist?," 351. McGregor concludes, similar to Dekker, that God's creates or actualizes the specific circumstances in which a individual will exercise his freedom of will. They also agree that the sets of circumstances are "freedom-preserving in character," see McGregor, Louis de Molina, 93, or "the relation between circumstances and human volition is not strictly implicative, and God has no control over the realizability of a certain relation between circumstances and human volition," see, Dekker, "Was Arminius a Molinist?," 351. 
libera naturally and consequently follows it. Therefore, contrary to his Reformed colleagues, for Arminius the cause of things depends partly on the natural knowledge of God and partly in the free decision of God's volition. ${ }^{118}$ It is also before the free act of divine will that God knows through his middle knowledge what free will creatures would actualize from all the possibilities already present in the mind of God. Consequently, God uses his natural knowledge of all possibilities and his middle knowledge of those most feasible actions of free will agents to determine by his sovereign will a specific reality. Logically, once that specific reality is determined by God, He actually has exhaustive and certain foreknowledge of all future events. From a logical perspective, this could really sound deterministic. It is important, however, to consider the way in which for Arminius this knowledge of God and the working of prevenient grace actualizes itself in time and history.

Evidently, the working of prevenient grace in Arminius's theology was greatly influenced by these previous concepts. Some necessary questions arise from Arminius's conceptualizations: Does prevenient grace work in a historical reality or only in the timeless life of God? Do human beings exercise their freedom of will in a historical reality or only in God's mind? It seems to me that Arminius did not answer these

${ }^{118}$ For Calvin and Reformed theologians in general, God foreknows because he wills. A script writer can serve as an illustration. A script writer writes a particular narrative that later is performed on stage. Likewise, God fore-writes future reality that later is played out exactly as God wrote it in history. Then, the Calvinist logical order of God's knowledge is this: God's will takes place in a historical continuum. Because he wills, he foreordains all events in a certain and specific way. As a result, God certainly foreknows all future reality. 
questions precisely, but if we follow his logic we can nonetheless draw some tentative conclusions.

The general tenor of Arminius's theology indicates that prevenient grace is granted to all human beings as a reality from the inner and eternal essence or understanding of God. In other words, God exhaustively foreknows those who will positively respond to the offer of salvation and those who will obstinately reject the working of prevenient grace in their hearts. While this knowledge is evidently present in the eternal and timeless life and knowledge of God, it is recapitulated in history. I mean that prevenient grace is not limited only to those who God foreknows will respond positively. Arminius clearly would note that such a conclusion would immediately be equated with Calvinist conclusions of limited grace. Rather, for Arminius every individual necessarily exercises their freedom of will to accept or reject the working of divine prevenient grace, although this be only a recapitulation in history of the eternal knowledge of God.

Arminius clearly pointed to both these realities, affirming: "Pre-damnation [predestination to damnation] is antecedent to all things; by no means does it exist without the foreknowledge of the causes of damnation." ${ }^{\prime 19}$ In this context, Arminius rejects a Calvinistic version of predestination because it requires that humans commit sins "without any foreknowledge of an inclination, will, or action on the part of man.",120

${ }^{119}$ Arminius, Declaration of Sentiments, in Gunter, Arminius and His Declaration, 132.

${ }^{120}$ Ibid., 120. 
Similarly, he clearly connected foreknowledge, prevenient grace, and election in the

fourth decree of divine predestination. He explains that:

This decree has its foundation in the foreknowledge of God, by which he knew from all eternity those individuals who would, through his preventing grace, believe, and, through his subsequent grace would persevere, according to the before described administration of those means which are suitable and proper for conversion and faith; and, by which foreknowledge, he likewise knew those who would not believe and persevere. $^{121}$

Arminius, in this way, preserved the biblical semantic tension or paradox between free will and divine foreknowledge as well as divine sovereingty. ${ }^{122}$ As I have already noted, Arminius's model still seems to be deterministic for some scholars. ${ }^{123}$

${ }^{121}$ Decl. Sent., in Works, 1:653-654; Arminius, Declaration of Sentiments, in Gunter, Arminius and His Declaration, 135.

${ }^{122}$ I see the tension in passages like Job 42:2; Isa.14:24; 43:13; 46:9-10; and Eph. 1:11 for divine foreknowledge and sovereignty and passages like John 12:48; 2 Cor. 5:10, 1 Tim. 2:4; and 2 Peter 2:9 for an equally emphatic affirmation of human freedom and responsibility.

${ }^{123}$ As we have noted, Arminius's concept of God's knowledge is evidently complicated and somehow ambivalent. There surely are certain elements in Arminius's concept of God's knowledge that could be interpreted as theologically and philosophically deterministic. Some scholars have previously noted deterministic elements in Arminius' theology, specifically in his conceptualization of God's knowledge. For instance, one could conclude from Dekker's analysis of Arminius's use of middle knowledge that Arminius was necessarily a determinist; see Dekker, "Was Arminius a Molinist?," 337-352. Roger Olson undoubtedly noted Dekker's implications of determinism in Arminius's theology, and concluded that he "tends to agree with Dekker." Then, he affirms, if Arminius effectively used middle knowledge, he contradicted himself making God the author of evil. See "Are Arminian Theology and Middle Knowledge Compatible?" in http://www.patheos.com/blogs/rogereolson/2013/09/are-arminian-theology-and-middleknowledge-compatible/, accessed January 28, 2016. Interestingly, Olson in his book Arminian Theology states "that Arminius occasionally but rarely said things that could be interpreted as Molinist," 194-197. To my mind, Arminius's use of the concept of middle knowledge is occasional and limited and did not necessarily result in determinism in his theology. See, Pub. Disp., IV, in Works, 2:123-124. This view is defended by Witt, who 
Nevertheless, I think, that he produced a non-deterministic alternative to the Reformed theology of his time. It even seems possible to say that Arminius mantained a traditional view of foreknowledge that implies determinism in a way that he did not intend.

As regards prevenient grace and foreknowledge, this seems obvious to me for three reasons: First, as we have previously seen, Arminius understood prevenient grace in particular and grace in general as a force that could be resisted. He affirmed, for example, that "if he [God] resolves to use a force that is not irresistible, but that can be resisted by the creature, then that thing is said to be done, not necessarily, but contingently, although its actual occurrence was certainly foreknown by God." ${ }^{124}$ Then, prevenient grace works

affirms that while Arminius discussed the biblical passages used by Molina, namely 1 Samuel 23 and Matthew 11, he "states that God knows what creatures might do or are able to do; he does not state explicitly that God knows with certainty what creatures will do or would do." See Witt, "Creation, Redemption and Grace," 364-365. It seems to me that Arminius did say "that God knows with certainty" the future free decisions of human beings, but that this divine certainty is rooted in divine knowledge and not in divine will. In this case, God's knowledge is certain, but it is not necessary. William den Boer also rejects a deterministic reading of middle knowledge in Arminius's writings. Indeed, he suggests that Arminius integrated middle knowledge "to create room for creaturely contingencies without harming God's foreknowledge and its certainty." He says that middle knowledge permitted Arminius to insist on both God's omniscience, God's control over his creation, grace, and human freedom without inconsistencies. On this, see den Boer, God's Twofold Love, 147. Stanglin and McCall argue against determinism in Arminius theology asserting that "Arminius affirms foreknowledge but rejects determinism," Theologian of Grace, 64-65. For what to me seems the best (though lengthy) analysis of Arminius's concept of God's knowledge, see Witt, "Creation, Redemption and Grace in the Theology of Jacob Arminius," 335-370. McCall argues that Arminius completely avoided determinism. See Thomas H. McCall, "Was Arminius and (Unwitting) Determinist? Another Look at Arminius's Modal Logic," Journal of Reformed Theology, 8 (2014): 301-309.

${ }^{124}$ Apology., Article V, in Works, 1:753. Elsewhere Arminius affirmed in his writings that contingency and necessity are logically incompatible. A divine or human act cannot be contingent and necessary at the same time. 
contingently in the human heart. While deciding for salvation, God does not impose necessity or coercion in the free exercise of the human will. At the same time, God eternally foreknew who "would believe by the assistance of his prevenient grace."125 Clearly, for Arminius, God's foreknowledge does not close the future until the human decision in favor or against prevenient grace actually occurs.

Arminius's conceptualization of a certain divine foreknowledge and human contingency brings us directly to his second affirmation. He understood God's infallible knowledge as passive or merely intellectual, and therefore not disruptive of human freedom of will. He said that God saw the human fall into sin from all eternity; however, the "fall happened infallibly, in respect only of that foreknowledge, not in respect of any act of God's will." ${ }^{126}$ Arminius clearly distinguished between infallibility and necessity, stating that while infallibility relates to God's eternal knowledge, necessity depends on God's will. ${ }^{127}$ Therefore, the infallible or certain knowledge of God of contingent things does not render them so necessarily, because God knows contingent things

${ }^{125}$ Apology., Article IV, in Works, 1:749.

${ }^{126}$ Junius Conf., in Works, 3:180.

${ }^{127}$ Arminius used the distinction of "necessity of the consequence" and "the necessity of consequent." See Perkins Exam., Works, 3:374- 375. Using Arminius's logic, necessity of consequence relates to God's infallible knowledge of humans actions, while necessity of consequent depends on the necessity of specific human actions. The first is passive knowledge of an event. The second is divine and active will that renders an event necessarily. Arguing with Perkins, Arminius said: "I allow, indeed, that 'man may sin infallibly, and yet freely:' but sinning infallibly and necessarily is not the same. For 'infallibly' is said with respect to the Divine prescience: but 'necessarily' with respect to God's decree and the Divine will," Perkins Exam., in Works, 3:375; see also Junius Conf., in Works, 3:180 and Stanglin and McCall, Theologian of Grace, 64. This distinction allows the exercise of human freedom of will. 
contingently. ${ }^{128}$ God has a passive or intellectual knowledge of future contingencies, but he does not will future contingencies.

In this context, an evidence that God neither wills nor exerts his omnipotent actions of future contingencies is Arminius's precise distinction between the foreknowledge of God and the omnipotence of God. I quote a large portion from Arminius's writing to support this idea:

For God, in virtue of His knowledge knew who by His grace would believe, and who by their own fault would remain in unbelief. I should wish with you [Perkins] to consider that the certainty of the event belongs properly to the foreknowledge of God; but the necessity, to the omnipotent and irresistible action of God: which, indeed, may be the foundation of the foreknowledge of some events; but is not of this, because God has determined to save believers by grace, that is, by gentle and sweet persuasion [the action of prevenient grace], fitting or congruous to their own will; not by almighty action or motion, which they neither will not can resist, nor can will to resist. Much less does the damnation of some proceed from irresistible necessity imposed by God. ${ }^{129}$

This distinction also helps Arminius to differentiate also between infallibility and necessity. ${ }^{130}$ For Arminius, because God only knows with certainty, the foreknowledge of God renders all actualization of future events infallible. This does not mean that God makes the future decisions of human beings happen because he does not use his

${ }^{128}$ Pub. Disp., IV, in Works, 2:123.

${ }^{129}$ Perkins Exam., in Works, 3:443. This distinction between foreknowledge/certainty/infallibly and omnipotence/necessity is well attested in Arminius's writings, see also Junius Conf., in Works, 3:180.

${ }^{130}$ Perkins Exam. in Works, 3:375. Arminius stated responding to Perkins regarding the actualization sin and the fall: "I allow, indeed, that 'man may sin infallibly, and yet freely:' but infallibly and necessarily is not the same. For 'infallibly' is said with respect to the infinite Divine prescience: but "necessarily,' with respect to God's decree and the Divine will, by which He wills sin to happen." 
omnipotence regarding the actualization of future contingencies. This is closely related in Arminius with the way in which he understood that prevenient grace works.

Thus, Arminius was not so much preoccupied with the affirmations of an exhaustive foreknowledge of God of the future human decisions as with the assertion that God's power or omnipotence unilaterally forced humans to act in a specific way. Thus, for Arminius, the certainty of knowledge of God does not impose necessity in the human will.

Third, Arminius defended the biblical tension between the liberty of human beings and the exhaustive knowledge of God of future reality. ${ }^{131} \mathrm{He}$ distinctly showed this tension by affirming that, on the one hand, "contingency and liberty do not make the prescience [foreknowledge] of God uncertain," ${ }^{\prime 32}$ but on the other hand, stating that God's understanding though "certain and infallible, ... does not impose any necessity on things [creatures]."133 He has both openness and foreknowledge. Though I do not find that Arminius completely exorcised the deterministic phantasm from his theology, by maintaining the tension he surely corrected the deterministic problem of the AugustinianCalvinist tradition. Indeed, I would like to suggest that in a sense Arminius offered one of the best solutions. Perhaps Christian theology only needs to maintain the biblical tension

${ }^{131}$ Many biblical passages clearly teach that God exhaustively knows present and future actions of free agents (for instances see Ps 147:5; Job 38:31-33; Is 46:10; Dan 2:36-43; 1 Sam 16:7; Jer 17:9-10; Rom 8:27; 1 Jn 3:19-20). At the same time, the Holy Scriptures affirm that humans are agents with freedom of will (for instances of this, see Deut 30:19-20; Job 24:15; Ezek 18:30-32; Jn 7:17; Rom 13:2; Rev 3:20).

${ }^{132}$ Priv. Disp., XVII, in Works, 2:344.

${ }^{133}$ Pub. Disp., IV, in Works, 2:123. 
between a God who foreknows all future reality and God's creatures that enjoy the gift of freedom to decide on a relational life with their Creator.

Arminius closely related his ideas of foreknowledge of future human response to prevenient grace to divine election. This means that for Arminius divine election rests on the human acceptance or rejection of God's prevenient grace. Arminius argued that since Christ is the truly elect, then those who choose Christ under the influence of the Holy Spirit and the working of prevenient grace are elected in Him for eternal salvation.

\section{The Spiritual Result of Prevenient Grace: Regeneration and Faith}

Before finishing our consideration of the concept of prevenient grace in Arminius's theology, it is critical to explore the spiritual results of prevenient grace in the believers. Because I have previously discussed sufficiently the first spiritual result of prevenient grace as the liberation of the human will, here I will uniquely focus on faith as the salvific result of prevenient grace.

In his writings Arminius gives special attention to the nature and role of faith in salvation. In order to understand Arminius's concept of faith, I think that his Oration "The Certainty of Sacred Theology" should receive our special attention. This is one of his Orations presented to students and faculty of Leiden University. Arminius defines certainty as "a property of the mind or understanding, and a mode of knowledge according [to] which the mind knows an object as it is, and is certain that it knows that object as it is. ${ }^{134}$ For Arminius, there are three causes of certainty: experience,

${ }^{134}$ Orat. 3., in Works, 1:375. 
knowledge, and faith. These three causes of certainty are produced in the mind by

different means. While experience produces certainty by sensorial activity, certainty of knowledge comes from the proper uses of reason. Human senses carefully observe and interact with external objects and reason deduces "general conclusions from known principles." 135

By contrast, faith obtains certainty from an external source, that is revelation. Arminius does not completely negate a role to the senses, reasoning, and discourse in faith, but he surely limits their scope in relation to revelation. Revelation is mandatory in the experience of faith because it brings to the human mind knowledge about God and Christ's nature and actions. ${ }^{136}$ Such revelation is contained in the Word of God or the Holy Scriptures that sufficiently have demonstrated its divine origin. ${ }^{137}$

According to Arminius faith entails more than "historical faith" and "theoretical knowledge" or to "believe that God and Christ exist."138 Salvific faith believes in God

${ }^{135}$ Orat. 3., Works, 1:377.

${ }^{136}$ Orat. 3., in Works, 1:377, 380-381.

${ }^{137}$ Ibid., Works, 1:383-401. Arminius presents eleven biblical proofs of the divine origin of the Scripture: 1) The internal testimony of Scriptures; 2) The way it reveals the nature of God and the person of Christ; 3) Its divine end: Glory of God and restoration of human beings; 4) The prophecies and predictions regarding the Messiah; 5) The style and character of the Scriptures as well as the promises and rewards contained in the Holy Word; 6) The miracles performed by prophets, apostles, and Christ; 7) The antiquity, propagation, preservation, and defense of the Scripture in history; 8) The sanctity of life in the biblical writers and believers; 9) The constancy of the martyrs in their suffering for the Word of God; 10) The testimony of the Church; and 11) The internal testimony of the Holy Spirit.

${ }^{138}$ Ibid., Works, 1:382. 
and Christ and in their affirmations concerning divine nature and actions. ${ }^{139}$ True and living faith, therefore, is practical and involves certainty $(\alpha \sigma \varphi \alpha \lambda \varepsilon \varepsilon \alpha)$; full assurance

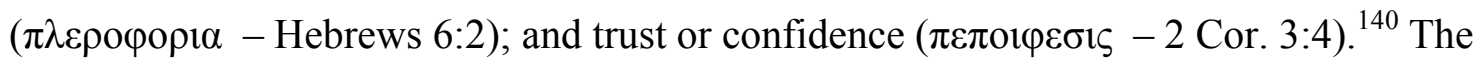
certainty of faith receives the word of God as true and divine in full assurance and confidence of its divine purpose and end. ${ }^{141}$ This faith is necessary and critical for the glory of God and the salvation of human beings. ${ }^{142}$

How is faith produced in our minds? For Arminius spiritual vision is made possible by the combination of an "external light" of arguments and reasoning and an "internal light" in the soul and mind resulting in a perfect "vision of faith." ${ }^{\text {"143 }}$ Because the objects of faith—God and Christ—are capable of being known, human beings need the combination of external and internal light that makes it possible to receive such knowledge of God. Faith, therefore, results from the external light contained in the Holy Scriptures and the internal light shining in the soul by the work of the Holy Spirit. I would like to suggest that according to Arminius the prevenient grace of the Holy Spirit produces salvific and living faith in the believers. He succinctly affirmed that "faith is the effect of God illuminating the mind." ${ }^{144}$ Faith, then, is in reality the result of the

${ }^{139}$ Orat. 3., in Works, 1:382.

${ }^{140}$ Ibid., Works, 1:382-383.

${ }^{141}$ Ibid., Works, 1:382.

${ }^{142}$ Ibid.

${ }^{143}$ Ibid., Works, 1:383.

${ }^{144}$ Quest. VI, in Works, 2:67. 
prevenient grace of God working through the Holy Scripture, other external souces like nature, and the illumination of the Holy Spirit. ${ }^{145}$

As we have previously seen, this relation of the Spirit and the Word in the context of prevenient grace in the writings of Arminius becomes particularly clear in his understanding of the role of the preaching of the word in the experience of conversion. Arminius discussed this relation referring to the Spirit as the first cause and the word as the instrumental cause in human conversion for salvation. I now turn to discuss this idea.

Arminius ardently defended faith as a free gift of God resulting from the illumination and consequent acceptance of prevenient grace. He returned to the analogy of the beggar as an argument in favor of the gratuity of prevenient grace resulting in faith. The illustration is not Arminius's invention, but rather was commonly used in a variety of ways by other Protestant reformers including Luther. ${ }^{146}$

A rich man bestows, on a poor and famishing beggar, alms by which he may be able to maintain himself and his family. Does it cease to be a pure gift, because the beggar extends his hand to receive it? Can it be said with propriety, that 'the alms depended partly on the liberality of the Donor, and partly on the liberty of the Receiver,' though the latter would not have possessed the alms unless he had received it by stretching out his hand? Can it be correctly said, because the beggar is always prepared to receive, that 'he can have the alms, or not have it, just as he pleases?' If these assertions cannot be truly made about a beggar who receives alms, how much less can

${ }^{145}$ Shultz Jr., came to a similar conclusion stating that, for Arminius, faith is a work of the Holy Spirit through prevenient grace," Multi-Intentioned View, 31. See also, F. Leroy Forlines, Classical Arminianism: A Theology of Salvation (Nashville, TN: Randall House, 2011), 132. Forlines discusses the relation between prevenient grace and faith in his analysis of a declaration from John Piper. He agree with Piper statement that "the act of faith is ultimately owing to the prevenient grace of God." However, Forlines understands that this prevenient grace does not entail a unconditional act, but it "leaves room for the individuals's reponse of belief."

${ }^{146}$ See Stanglin, Arminius on the Assurance of Salvation, $97 \mathrm{n} 97$. 
they be made about the gift of faith, for the receiving of which far more acts of Divine Grace are required! ${ }^{147}$

Arminius did not discuss all the theological implications of the analogy. His main concern was to evidence the compassionate action of the benefactor and the willing acceptance of the gift by the miserable person. Arminius argued that although the beggar is actively involved in the action, she could not boast and credit herself for the event. The benefactor deserves all recognition and praise for the gracious gift.

However, a different possible assumption could rightly arise from the analogy. Because the beggar is begging, his action moves the rich man to compassion. This reading implies that by begging, the beggar is conscious of his condition and is looking for external help in order to save his life. Reading the analogy in this way results in some semi-Pelagian connotation not necessarily intended by Arminius. This is precisely the conclusion of Muller and J. V. Fesko. They note that Arminius speaks not simply of any kind of beggar, but one who is "always prepared to receive." In this expression, they find a semi-Pelagian view or medieval synergism of grace in Arminius's theology. Muller concludes that the expression parallels "the late medieval maxim, 'facientibus quod in se est, Deus no denegat gratiam." ${ }^{148}$ Similarly, using this expression in conjunction with several others from Arminius's writing, Fesko states that “Arminius's construction is not

${ }^{147}$ Apology, Article XXVII, in Works, 2:52.

${ }^{148}$ Muller, "The Priority of the Intellect in the Soteriology of Jabob Arminius," WTJ 55.1 (1993), 60. For an analysis of the medieval concept facientibus quod in se est deus non denegat gratiam see Heiko A. Oberman, The Reformation: Roots and Ramifications, trans. Andrew Colin Gow (New York, NY: T\&T Clark, 1994), 104-107. 
Pelagian, but it does fall into a semi-Pelagian category."149 ${ }^{14 i k e ~ M u l l e r ~ b e f o r e ~ h i m, ~}$ Fesko finds Arminius's source in the semi-Pelagian medieval theology of Gabriel Biel. ${ }^{150}$ Although I recognize the tension between the role of God and the role of humans in the beggar analogy, as a result of my study I disagree with Muller and Fesko's conclusions for several reasons:

First, Fesko collocates the working of prevenient grace in the context of a natural or creational human will. This is quite contrary to Arminius's conclusions. Arminius continually emphasized that in order to receive or accept grace individuals previously need to be liberated by prevenient grace. In Arminius's theological conceptualizations, regeneration of the will and the spiritual capacities must be experienced before human beings can participate in the acceptance of salvation. Elsewhere, Arminius emphasized the concept that one of the primary results of prevenient grace is regeneration of the "mind and feelings," or "mind and affections,", 151 in order that individuals be rendered spiritual and capable of performing good. He quoted scriptural verses profusely, among them Phil 2:13; Eph 2:10; and 2 Cor 5:17, to support his conclusions that only a human regenerated by the prevenient grace of God could will and perform what is really good. ${ }^{152}$

${ }^{149}$ Fesko, “Arminius on Facientibus,” 356.

${ }^{150}$ Fesko concludes that "Arminius clearly states that if a person's will concurs with prevenient grace, then more grace is given unless he resist the prevenient grace," 352.

${ }^{151}$ Art., XX, in Works, 2:724. See also Rom. VII, in Works, 2:539.

${ }^{152}$ The idea that the free will of humans must first be regenerated or liberated by the prevenient grace of God is well attested and clear in Arminius writings. See Rom. VII, in Works, 2:538; Pub. Disp., XI, in Works, 2:189-196. Arminius always understood there 
Interestingly, for Arminius this work of regeneration is not a unique and one-time event in life, but it is continually perfected in "steps and intervals" as a daily salvific experience of the believers. ${ }^{153} \mathrm{He}$ also stated that the human must experience the regeneration of their "intellect, affections, [and] will" before they can "understand, esteem, consider, will, and perform, that which is truly good." ${ }^{154}$ Therefore, according to Arminius this essential spiritual result of prevenient grace does not open a place for a creational or natural freedom of will. Willing or accepting salvation, in Arminius's theology, is always a result of prevenient grace, not a result of a natural endowment.

Second, Fesko also says that Arminius's use of this phrase in the analogy of the beggar differs from that of other Reformed theologians like Zacharias Ursinus (15341583), Thomas Goodwin (1600-1680), and others. ${ }^{155}$ However, this conclusion seems to me to be somewhat misleading. A closer comparison between Arminius's and Goodwin's view of the will shows a complete agreement. Fesko quotes Thomas Goodwin as asking: "Does the hand of a beggar that takes alms return any thing to the man that gives? No, it

to be a three stages or conditions of humans in relation to their freedom of will. In their "primitive innocence" humans enjoyed an unblemished free will. After the fall into sin, their state of "corruption" obliterated and destroyed completely their freedom of will, desire, and performance of spiritual good. And finally, after the regeneration or liberation of their freedom of will by God's prevenient grace, they are again able to accept the offer of salvation and experience a new relationship with God.

${ }^{153}$ Pub. Disp., XI, in Works, 2:195. See also Rom. VII, in Works 2:550.

${ }^{154}$ Gunter, Arminius and His Declaration of Sentiments, 140; Decl. Sent., in Works, 1:659.

${ }^{155}$ Fesko, “Arminius on Facientibus,” 352-353. 
only takes it." ${ }^{, 156}$ This is very similar to Arminius's rhetorical question: "Can it be said with propriety, that 'the alms depended partly on the liberality of the donor, and partly on the liberty of the receiver,' though the latter would not have possessed the alms unless he had received it by stretching out his hands?" No, it cannot, Arminius would respond. Arminius clears all doubt about this, and concludes that to receive "the gift of faith ... far more acts of divine grace" ${ }^{157}$ are needed, meaning that prevenient grace must work in advance.

Third, Fesko further argues that the medieval theologians already mentioned are the likely sources of Arminius's facientibus formula. Certainly, Arminius agreed with the medieval theologians about the universality of prevenient grace. Arminius also assigned a role to God's providence in the impartation of prevenient grace. But, contrary to Fesko's argument, Arminius did not accept the concept of a "creational" or natural prevenient grace. Quite the contrary: for Arminius prevenient grace is a post-creation and post-fall gift of the Holy Spirit. In other words, it is imparted by the influence of the Holy Spirit as a solution to the problem of sin. It is not a gift received or possessed by the act of creation as a natural or innate capacity.

Fourth, in my opinion Fesko and Muller fail to observe that Arminius begins his analogy focusing not on the beggar but on the compassion of the rich man. The rich man is moved to compassion by the condition of the beggar, not by her begging actions. This conclusion clearly appears elsewhere in Arminius's writings. For instance, as we

${ }^{156}$ Fesko, “Arminius on Facientibus," 353. 
previously discussed, in his Oration The Priesthood of Christ, Arminius undoubtedly describes the condition of the beggar as "most miserable" and the salvific actions of God toward the poor individuals as "full of mercy." 158 The merciful action of God results from His compassion toward the wretched condition of the individual, not from the beggar doing first what it is in herself.

Fifth, Arminius's main point seems to be that by receiving alms the beggar does not perform a meritorious salvific action. Arminius actually points out that the beggar is "always prepared to receive," but here he is only describing the needed condition of the beggar. I understand that Arminius's point is that the beggar is "prepared to receive" not because she has previously prepared herself "to receive," but because she is in need "to receive." Furthermore, in Arminius's theology, preparation "to receive" occurs as the result of the Holy Spirit's actions by prevenient grace.

Finally, using the beggar analogy Arminius emphasized that grace is truly freely offered, but it is not sovereignly imposed. Arminius certainly was a synergist, but in relation to salvation and faith he limited his synergism to acceptance. This basically means, that for Arminius, acceptance is not necessarily equal to meritorious collaboration. Indeed, acceptance results from the strengthening, accompanying, and continual assistance of human freedom of will by God's grace. Arminius made clear this reality in the conclusion of the illustration, by affirming that the "receiving" of the "gift of faith" is accompanied by a great number of actions of divine grace.

${ }^{157}$ Apology, Article XVII, in Works, 2:52. 
Several scholars read the analogy of the beggar in Arminius's writing as contrary to the spirit of semi-Pelagianism. Olson finds in Arminius's analogy a "synergism that preserves all the power, ability and efficacy in salvation to grace." ${ }^{159}$ He further affirms that for Arminius "the only 'contribution' humans make is non-resistance to grace. This is the same as accepting a gift." ${ }^{\prime 60}$ Indeed, this is the kind of acceptance exemplified in the actions of the beggar. Stanglin and McCall conclude that Arminius's "chief point is that donation of money, like faith, is still a pure gift, even if the beggar is ready to receive it," because for Arminius, "there are other gifts and persuasions that precede this gift of faith and prepare the will to receive it." ${ }^{\prime 161}$ Similarly, Gijsbert van den Brink states: "The advantage of the beggar-metaphor is that it underlines the asymmetrical nature of the divine-human relationship. It shows that the bringing about of salvation is a 'one-sided act of God,' for which He and He alone is to be credited and praised. But at the same time it demonstrates how it is possible that God's power does nevertheless not remove the human freedom of choice." ${ }^{162}$ In summary, the analogy of the beggar provided Arminius with an excellent illustration of the working of prevenient grace and the consequent result of faith and salvation. It also demonstrates, from my point of view, the

${ }^{158}$ Orat. 4, in Works, 1:410.

${ }^{159}$ R. Olson, Arminian Theology, 165.

${ }^{160}$ Ibid.

${ }^{161}$ Stanglin and McCall, Theologian of Grace, 166-167. See also, Stanglin, Arminius on the Assurance of Salvation, 97-98.

${ }^{162}$ Gijsbert van den Brink, Almighty God: A Study of the Doctrine of Divine Omnipotence, Studies in Philosophical Theology (Kampen, the Netherlands: Pharos, 
necessary spiritual result of regeneration or rather the liberation and empowerment of human freedom of will and spiritual capacities and the actualization of actual faith in those who do not reject the working of the Holy Spirit in their life.

\section{Prevenient Grace as Organizing Principle in Arminius's Soteriology}

If one is looking for a central and organizing principle by which Arminius's individual soteriological teachings may be related to each other, that principle is prevenient grace. Prevenient grace provides Arminius with the internal logic to his espousal of grace and free will, God's sovereignty and human responsibility; love and justice, divine election/predestination and human faith; and divine foreknowledge and human future decisions.

An organizing principle is an idea or concept through which a whole system of thinking can be explained and understood. It is also the supporting factor or what holds together the whole system and structure. Prevenient grace is central in Arminius's soteriology because it functions as this organizing principle to give coherence, meaning, presuppositional support, and logical order to all his soteriological constructions. I think that deprived of prevenient grace, Arminius's soteriology would fall apart like a house of cards into a heretical system of salvation like Pelagianism. In this context, for instance, prevenient grace helps us to appreciate Arminius's positive view of freedom of will and human nature. His positive anthropology, therefore, is the result of God's prevenient grace.

1993), 239. 
Consequently, Arminius used the doctrine of prevenient grace as a correction to both Pelagian and Reformed soteriology. Arminius rejected Pelagianism for negating the deep consequences that sin inflicted on human nature. The solution, for Arminius, is not to stress an independent and capable human freedom of will, but to point to prevenient grace as the divine healing and liberation of human-damaged freedom to establish a relationship with God. In this way, Arminius sustained both the biblical doctrine of total depravity and the free will of human beings.

Likewise, Arminius rejected the predestinarian view of Reformed theology. For Arminius, the solution is not an irresistible work of God's grace to awaken dead individuals from their sinful perversions. Rather, it is prevenient grace that with gentle persuasion monergistically empowers and restores human freedom of will, by inviting individuals to a covenant relationship of salvation with God. Thus, prevenient grace as an organizing principle allowed Arminius to balance the doctrine of total depravity, the doctrine of freedom of will, and the doctrine God's sovereignty in salvation.

As we have seen, since Augustine and throughout the medieval era, theologians used the concept of prevenient grace in diverse ways. Likewise, Reformation theologians like Melanchthon and the Anabaptists used prevenient grace in their conceptualization of conversion. It seems to me, then, that Arminius successfully draws from the theological teaching of the Church the doctrine of prevenient grace as an organizing principle to correct both medieval and Reformed theology alike. In this way, Arminius was able to hold together the biblical claims of God's grace and the liberty of human will. 


\section{Summary and Conclusion}

Throughout the analysis of Arminius's conception of prevenient grace, many important aspects of this idea have surfaced.

The language of universality of prevenient grace clearly demonstrates that Arminius believed that the Holy Spirit works in every human being. In Arminius's soteriology, prevenient grace is critical because of its universal scope. Early Church Fathers like Prosper and Augustine gave Arminius the rationale for a universal operation of prevenient grace. Like Prosper before him, Arminius believed that God's prevenient grace aids humans in different ways, forms, moments, and experiences. For Arminius, God's justice demands that prevenient grace is given to every individual. Otherwise, he believed that God cannot condemn to eternal perdition one of his creatures without giving them an opportunity to respond God's offer of salvation. It is not only out of justice that God has decided to grant prevenient grace to all humans, but also out of love. This love was most fully demonstrated on the cross. Christ gave his life and defeated sin and death to open a way of salvation for all humans. It is in the working of prevenient grace that all humans participate in the merits and application of the atonement. This, as I demonstrated, does not mean that the actualization of faith and salvation or the efficacy of the atonement pertains to all, because once the benefits of prevenient grace have been applied and the human will freed, humans need to accept the working of salvation.

I explored several other layers of evidences in Arminius writings regarding the universality of prevenient grace in the working of salvation. I believe that Arminius's concept of covenant also points to a common working of prevenient grace. The covenant of redemption, for Arminius, is the pathway by which every individual of the human race 
is embraced into the salvific purpose of God. This becomes a reality in the battle between the Spirit and the flesh described by Paul in Romans 7. Arminius distanced himself from the interpretation of his day that understood the "I" of Romans 7 as a converted believer. Instead, for Arminius this human being is an unconverted individual on the path of regeneration. This struggle present in every human being is evidence that the Holy Spirit is working by his prevenient grace in the heart of all humanity. This battle between the Spirit and the flesh is an opportunity for the universal vocation to salvation. For God's justice cannot lie or mislead; when God calls, he is serious. A universal invitation to salvation means that God has freed the human will, thus giving everyone the power to respond to the Gospel.

Perhaps one of the most challenging proposals of my research regarding the universal scope of prevenient grace is the extent to which I think Arminius understood the special working of the Holy Spirit. For Arminius, the Holy Spirit may work in special and unknown ways in those places where the preaching of the word is not present. He argued that good works prove that the Holy Spirit is working even in the hearts of heathens. For me, this was a surprising finding in Arminius. It seems to me that he comes close to defending a universal grace working through the means of nature. However, a careful reading of his ideas demonstrates that for Arminius even the working of the Holy Spirit through the testimony of nature is not deprived of the internal prevenient grace of God. For, different to the medieval theologians, Arminius brings natural theology within the contours of prevenient grace. This is an important contribution of Arminius to the concept of the universality of prevenient grace. 
The only barrier that I found to a universal understanding of prevenient grace in Arminius's theology is Arminius's conceptualization of divine foreknowledge. As we have seen, some scholars believe that Arminius ultimately was a determinist. If he had a determinist view of God's foreknowledge of future contingencies, the scope of prevenient grace could not be universal, but would be limited to the elect. However, such a conclusion contradicts the tenor of Arminius's entire theology and his main goal to portray divine actions as allowing the participation of human freedom of will. Although I did not develop a totally comprehensive understanding of Arminius's concept of divine foreknowledge, I propose that Arminius allowed a tension to exist between the exhaustive knowledge of God of future contingencies and the liberty of human free will. It seems evident to me that the knowledge of God of the future is passive and intellectual, although certain or infallible. It therefore does not impose any necessity on human liberty. Certainly, God foreknows those who will accept prevenient grace by the restoration of their freedom of will by the working of the divine prevenient grace, and those who will reject it by their own corrupted will. But, this does not mean that God in any way forces them into a particular decision.

The working of prevenient grace as a gentle suasion or persuasion of the Holy Spirit in the human heart results in actual regeneration, liberation, and empowerment of the dead and sinful freedom of human will. This regeneration allows humans to participate, not in a cooperation equal to God's work on them, but by accepting the offer of salvation and not resisting the working of the Holy Spirit. Accepting the invitation results in faith in Christ and in His work of salvation in their favor. At this point, it is important to highlight that faith for Arminius is a complete gift of God. The only way in 
which humans participate in the process is by accepting the gift by the working of prevenient grace.

In the last section of this chapter, I proposed that prevenient grace is the organizing principle of Arminius's soteriology or ordo salutis. Arminius's conceptualization of the human will and the role of humans in accepting salvation would be seriously misunderstood if it were not read within the framework of God's prevenient grace. This suggests that all quotations from Arminius's writing that have any flavor of semi-Pelagianism or radical synergism must be understood in the context of prevenient grace. It seems clear to me that whenever Arminius talked about human will and human acceptance of salvation, even if it was not openly present, prevenient grace was always in the background of Arminius's intentions. In other words, he presupposed the sovereign and monergistic working of prevenient grace before any participation of human will in salvation. 


\section{CHAPTER 6}

\section{CONCLUSIONS AND RECOMMENDATIONS}

I do not want to bore my readers with another summary of the main points of my dissertation. Summaries of my findings are already an integral part of the conclusions and summaries of each chapter. Therefore, I limit my work here to presenting my specific findings and conclusions about the concept of prevenient grace in Jacobus Arminius's theology, and making some recommendations for future research on this topic.

Arminius was a child of a troubled and changing world. His was a time of

political, social, and religious upheaval. His early life experiences were painful. Suffering seems to have been a daily reality throughout his life. However, these experiences prepared him for a ministry of compassion and a solid academic career as a professor of theology at Leiden University. Arminius came reluctantly to the debate about predestination in the Reformed Church in Netherlands. Because (to our knowledge) he did not write anything before 1590 , we can only speculate about his points of view before that year. Nevertheless, I found a tension between his early education and the time in which he studied sacred theology in preparation for ministry. While his early education was more influential with regard to developing a concept of human freedom of will, his later education was one of solid Reformed theology and doctrine. Records of his time in Geneva under the tutoring of Beza do not indicate that he was an opponent of the predestinarian and Reformed model of salvation. Arminius used to speak his mind; for 
instance, in Geneva he openly disagreed with Beza regarding topics of philosophy and logic. So it would be very unlikely that, if at that time he already disagreed with the Reformed view of predestination, he would have remained silent. Therefore, I suggest that Arminius changed his mind after 1590 not as a betrayal to his Reformed commitments - for in his mind he was always a faithful pastor of the Reformed tradition—nor because of competing external theological influences, but because of his careful and intentional exploration of the biblical text and the theological tradition of the Christian church. Thus, his biblical and theological explorations led him to discover prevenient grace as a proper solution to maintaining a view of salvation that on the one hand credits all merit and glory to God, and on the other hand recognizes that humans participate in accepting the divine invitation.

As we have seen, Arminius obviously did not create this idea. Prevenient grace as a theological idea had had an extensive history in the history of Christian doctrine long before Arminius, indeed since the time of Augustine. However, Arminius's conceptualization of it balanced some of the previous views of prevenient grace and was in continuity with some of them. He would agree with Augustine, the Fathers of the Second Council of Orange, Melanchthon, and the Anabaptist preachers that prevenient grace is the necessary and previous working of God's love and grace in the human heart before any willingness of the individual to receive and accept salvation. Like them, he also visualized prevenient grace as the gratuitous gift of the Holy Spirit to a human in a state of total corruption. However, he completely sided with the Council, against Augustine, while affirming that the gift of prevenient grace could be rejected by the human will. In contrast to the Councils of Orange and Trent but like Melanchthon and the 
Anabaptists, he understood the working of prevenient grace to ordinarily to occur at the intersection of preaching and the internal work of the Holy Spirit rather than exclusively at the moment of baptism.

However, there are also important points of discontinuity between Arminius and other scholars. Different from the medieval theologians, Arminius believed that prevenient grace comes from divine love and grace and is not a natural endowment received by individuals at creation. He disregarded a "creational prevenient grace" in favor of an unmerited, supernatural, post-creational prevenient grace. He would also disagree with the medieval theologians, like Molina, that prevenient grace is only an accompanying, supporting, or concurrent aid to a weak and wounded free will but in some way still capable of consenting with the working of prevenient grace. Rather, for him prevenient grace entails the complete restoration or liberation of a completely lost and dead freedom of will. Nevertheless, he certainly accepted the conclusions of the medieval theologians that prevenient grace works universally in all human beings by calling them into a salvific relationship with God.

Arminius's concept of prevenient grace is highly pneumatological in nature. In this regard he closely followed the contributions in the realm of conversion of some earlier protestant theological reformers, like Melanchthon and the Anabaptists. This emphasis on pneumatology as the relationship between the Spirit and the individual distances Arminius from the concept of prevenient grace as a metaphysical substance infused in the human soul that was so present in the medieval theological conceptualizations. Similar to Melanchthon, for Arminius the internal illumination of the Holy Spirit working on the human understanding, will, and heart is the most critical 
operation of prevenient grace. Also, similar to his Reformation contemporaries, Arminius viewed prevenient grace not only as a supporting aid, but more precisely as a power that heals, frees, and liberates the human will. For Arminius and Melanchthon, this working of God's prevenient grace does not erode the decision of human freed will.

Thus, a proper definition of prevenient grace in Arminius's theology is:

Prevenient grace usually entails the preceding and divine working of God's mercy and grace toward sinful humans that works internally by the illumination of the Holy Spirit and externally by the preaching of the Gospel. Prevenient grace heals, empowers, and frees the enslaved freedom of will, giving humans the opportunity to receive and accept the invitation and the call to the experience of salvation.

For me, a surprising finding of my study was that for Arminius there actually exists a monergistic and sovereign operation of prevenient grace. This means that, before everything, prevenient grace monergistically operates in the human heart to restore its freedom of will. That is, it gives the person power to understand the Gospel and accept the work of Christ in its favor. In this way, Arminius understood that the initial working of prevenient grace occurs in an unavoidable manner in human beings. God renews and heals human infirmities and gives them a completely freed will. Once humans enjoy their freed will, they have a measure of a restored spiritual capacity to respond to God and receive the gift of faith. In this way, Arminius also understood that prevenient grace is resistible. The freed will of humans not only has the capacity to accept, but because the corruption of sin is still present in the human heart, it has the capacity to reject the offer of salvation. Arminius in this way restricted the participation of humans in salvation to the need to respond to God's gift and offer of redemption. This is the balance that 
Arminius proposed to correct both the irresistible working of God's grace of the Augustinian/Reformed tradition and the high anthropology of an unblemished or only weakened freedom of will of the Pelagian/Semi-Pelagian tradition.

I also discovered in my research that for Arminius the universal scope of prevenient grace goes well beyond where the preaching of Scripture and the Gospel takes place. The Holy Spirit works in unknown or unrevealed ways and manners to restore humans to a spiritual relationship with God. The battle that occurs in the unregenerate person between the Holy Spirit and the flesh is a universal experience, that, although it is reinforced by the preaching of the word, is experienced to a greater or lesser extent by all individuals. For Arminius, even the evidence of God in nature is an integral part of prevenient grace and in some ways enough to be used by the Holy Spirit to illuminate the human heart. This does not mean that Arminius rejected the notion of the necessary union of the Spirit and the Word. But it does means that the prevenient grace of God is sometimes working long before the individual comes to the knowledge of the Word or to hearing the preaching of the Gospel. The language of universality of prevenient grace is also possible to find in Arminius's conceptualization of the character of God, the extent of the atonement, and the divine covenant. Particularly interesting in this regard is Arminius's understanding that the universal intention of God's sacrifice is effectually actualized in the working of prevenient grace. Although God's sacrifice does not ultimately mean that every human being will enjoy final salvation, it effectively opens a way for all humans, giving them a freed will to respond to God's love and mercy.

As I have previously mentioned, a freed will is the first spiritual result of the working of prevenient grace. Once humans accept using their freed will to respond to the 
offer of salvation, the second spiritual result is faith in Christ as Lord and Savior. For Arminius, acceptance of the gift does not add merit to the human action, just as the beggar does not deserve the food more by extending her hand to receive it. Therefore, faith is properly a work of prevenient grace, that is, the internal light of the Spirit making effective the external light of the Scripture.

All these characteristics of prevenient grace and its role in salvation in Arminius's theology led me to propose that in Arminius's writings prevenient grace is the organizing principle of his soteriology. We best understand Arminius's doctrine of salvation and his ideas of human freedom of will in the context of prevenient grace. For prevenient grace is the principle that holds together all the elements of Arminius's soteriology.

\section{Suggestions for Further Studies in Arminius}

Arminius's life, ministry, writings, and theology are now getting more attention in academic works. Though there are abundant possible topics for further research on Arminius, here I limit my suggestions to some areas related to the concept of prevenient grace and freedom of will in Arminius's theology that further research might illuminate, both historically and theologically.

First, it would be helpful to compare Arminius's concept of prevenient grace with his contemporaries within the Reformed Tradition. For instance, although some scholars think that only Arminius and Arminians are truly advocates of preparation for grace and faith, William Perkins's work contains significant material on preparation for faith that mimics the concept of prevenient grace. Is preparation for faith intrinsically distinct from prevenient grace? Is the difference between preparation for faith in Reformed theology in 
Arminius's time and the concept of prevenient grace in Arminius's writings limited to the resistible/irresistible nature of grace?

Second, the main work of prevenient grace is to restore the liberty of human freedom of will. I have explored some connections between prevenient grace and freedom of will. However, much research remains to be done regarding the concept of freedom of will in Arminius's writings. In connection with free will, the concept of divine freedom should be explored in Arminius's theology. Arminius implies that God is good by necessity. He specifically says that "God is not freely good; that is, he is not good by the mode of liberty, but by that of natural necessity." In light of this, a research question could be: If God is not free to do otherwise, can humans really enjoy a kind of freedom that God is not entitled to have?

Third, in my first chapter I suggested that more historical work needs to be done to discover the connection and influence of English free-will thinkers on Arminius and vice versa. In this context, it would be helpful to explore the influence of the Danish Lutheran theologian Neils Hemmingsen (Nicholas Hemmingius) on Arminius, Corro, and Baro. It would also be important to explore Hemmingsen's writings to unearth his concept of prevenient grace or his theology of conversion, if any.

Finally, I think that a more comprehensive study is needed on the soteriological function of prevenient grace. I have explored some ideas on this in my research, but a broader exploration of Arminius's doctrine of conversion is critical. Such research would

${ }^{1}$ Apology, Article XXII, in Works, 2:34. 
explore the connections of prevenient grace with the concepts of repentance, the complete process of regeneration, and union with Christ in Arminius's writings. 


\section{BIBLIOGRAPHY}

\section{Primary Sources}

Arminius, James. The Works of James Arminius. Translated by James Nichols and William R. Bagnall. Auburn: Derby, Miller and Orton, 1853.

. The Works of James Arminius. Translated by James and William Nichols. Grand Rapids, MI: Baker Book House, 1986.

. and Keith D. Stanglin. The Missing Public Disputations of Jacobus Arminius: Introduction, Text, and Commentary, Brill's Series in Church History. Leiden, the Netherlands: Brill, 2010.

. and Petrus Bertius and Pre-1801 Imprint Collection (Library of Congress). Iacobi Arminii, Opera Theologica. Lugduni Batavorum, Apud Godefridum Basson, 1629, in the HathiTrust Database, http://hdl.handle.net/2027/dull.ark:/13960/t00010j48 (accessed September 3,iu 2012).

Praestantium ac eruditorum virorum epistolae ecclesiasticae et theoloicae, ed. Christian Hartsoeker and Phillip van Limborch. Amsterdam, the Netherlands, 1660.

\section{Secondary Sources}

Alberigo, Giuseppe. "Trent, Council of" in The Oxford Encyclopedia of the Reformation, edited by Hans J. Hillerbrand. New York: Oxford University Press, 1996.

Allen, David L. The Extent of the Atonement: A Historical and Critical Review. Nashville, TN: B\&H Academic, 2016.

Allison, Gregg R. Historical Theology: An Introduction to Christian Doctrine. Grand Rapids, MI: Zondervan, 2011.

“Arminianism," in Seventh-Day Adventist Encyclopedia. Edited by Don F. Neufeld, Revised Edition. Washington, D.C.: Review and Herald, 1976.

Aquinas, Thomas. Commentary on the Gospel of John, Vol. 1, Chapters 1-8, Translated by Fr. Fabian R. Larcher, O.P., and edited by The Aquinas Institute. Lander, WY: The Aquinas Institue, 2013. 
. Commentary on the Gospel of John, Vol. 3, Chapters 13:21, Translated by Fabian Larcher, O.P., and James A. Weisheipl, O.P. Washington, D.C.: The Catholic University of America Press, 2010.

. Summa Theologica. Vols. 1 to 3. Translated by Fathers of the English Dominican Province. New York: Benzinger Brothers, 1947.

Aquitaine, Prosper of. De Providentia Dei, Text, translation, and commentary by Miroslav Marcovich. Leiden, the Netherlands: Brill, 1989.

Augustine. De gratia et libero arbitrio, in Nicene and Post-Nicene Fathers (NPNF). Edited by Philip Schaff, translated by P. Holmes and Robert E. Wallis, and revised by Benjamin B. Warfield., vol. 5: Augustine: Anti-Pelagian Writings. New York: Christian Literature Company, 1887, reprint, 2012.

. De natura et gratia, in Nicene and Post-Nicene Fathers (NPNF). Edited by Philip Schaff, translated by P. Holmes and Robert E. Wallis, and revised by Benjamin B. Warfield., vol. 5: Augustine: Anti-Pelagian Writings. New York: Christian Literature Company, 1887, reprint, 2012.

. De peccatorum meritis et remissione, et de baptismo parvulorum, in Nicene and Post-Nicene Fathers (NPNF). Edited by Philip Schaff, translated by P. Holmes and Robert E. Wallis, and revised by Benjamin B. Warfield., vol. 5: Augustine: Anti-Pelagian Writings. New York: Christian Literature Company, 1887, reprint, 2012.

. De perfection justiciae hominis, in Nicene and Post-Nicene Fathers (NPNF). Edited by Philip Schaff, translated by P. Holmes and Robert E. Wallis, and revised by Benjamin B. Warfield., vol. 5: Augustine: Anti-Pelagian Writings. New York: Christian Literature Company, 1887, reprint, 2012.

. De spirit. et littera., in Nicene and Post-Nicene Fathers (NPNF). Edited by Philip Schaff, translated by P. Holmes and Robert E. Wallis, and revised by Benjamin B. Warfield., vol. 5: Augustine: Anti-Pelagian Writings. New York: Christian Literature Company, 1887, reprint, 2012.

. "Zacchaeus" Sermon 174, in "Sermons," The Works of Saint Augustine: A Translation for the 21st Century. Translated by Edmund Hill, and edited by John E. Rotelle. New Rocelle, NY: New City, 1992.

Balcanqual, Walter. "Dr. Balcanqual's Letters From the Synod of Dort to the Right Honourable Sir Dudley Carlton, Lord Embassador," in John Hales, Golden Remains of the ever Memorable Mr. John Hales, of Eaton-College, with Additions from the Author's Own Copy, vol. 12, 4th ed. London: E. Pawlet, 1711. 
Balke, Wim. "Calvin and the Anabaptists," and Mirjam G. K. van Veen "Calvin and His Opponents," in The Calvin Handbook, ed. Herman J. Selderhuis, trans. Henry J. Baron, Judith J. Guder, Randi H. Lundell, and Gerrit W. Sheeres. Grand Rapids, MI: Eerdmans, 2009.

Bangs, Carl. The Action Catalogue of the Library of J. Arminius: A Facsimile Edition with an Introduction. Utrecht, the Netherlands: Hes, 1985.

. “Arminius and the Reformation,” Church History 30, no. 2 (1961):155-170.

. “Arminius: An Anniversary Report," Christianity Today 5 (10 October, 1960): 19.

. Arminius: A Study in the Dutch Reformation. Eugene, OR: Wipf and Stock, 1985.

Bangs, Jeremy Dupertuis. "Beyond Luther, Beyond Calvin, Beyond Arminius: The Pilgrims and the Remonstrants in Leiden, 1609 - 1620," in Reconsidering Arminius: Beyond the Reformed and Wesleyan Divide. Edited by Keith D. Stanglin, Mark G. Bilby, and Mark H. Mann. Nashville, TN: Kingswood and Abingdon, 2014.

Bangs, Nathan. The Life of James Arminius, D.D., Formerly Professor of Divinity in the University of Leyden. New York: Harper \& Brothers, 1843.

Baro, Peter. "Three Opinions Concerning Predestination," in Jacobus Arminius, The Works of James Arminius. Translated by James and William Nichols. Grand Rapids, MI: Baker Book House, 1986.

Bender, Harold S. "The Anabaptist Vision" in The Recovery of the Anabaptist Vision: A Sixtieth Anniversary Tribute to Harold S. Bender. Edited by Guy F. Hershberger. Scottdale, PA: Herald Press, 1957.

Bertius, Peter. "An Oration on the Life and Death of that Reverend and Very Famous Man James Arminius, D. D." in The Works of James Arminius. Translated by James and William Nichols. Grand Rapids, MI: Baker Book House, 1986.

Bird, Michael. Evangelical Theology: A Biblical and Systematic Introduction. Grand Rapids, MI: Zondervan, 2013.

Blacketer, Raymond A. "Arminius's Concept of Covenant in Its Historical Context," Dutch Review of Church History/Nederlands Archief Voor Kerkgeschiedenis 80/2 (July 2000):193-220. 
Boniface, Ramsey. "John Cassian and Augustine," in Grace for Grace: The Debates after Augustine and Pelagious. Edited by Alexander Y. Hwang, Brian J. Matz, and Augustine Casiday. Washington, D.C.: The Catholic University of America Press, 2014.

Bradley, James E. and Richard A. Muller. Church History: An Introduction to Research, Reference Works, and Methods. Grand Rapids, MI: Eerdmans, 1995.

Brant, Caspar. The Life of James Arminius. Translated by John Guthrie. London: Ward and Lang. Adamson, 1854.

Brian, Rustin E. Jacob Arminius: The Man from Oudewater. Eugene, OR: Cascade, 2015.

Brown, Peter. Augustine of Hippo: A Biography. New York: Dorset Press, 1986.

Bruyn, Theodore de. "Introduction,", in Pelagious's Commentary on St Paul's Epistle to the Romans. Translated by Theodore de Bruyn. New York: Oxford University Press, 1993.

Bryant, Barry E. "Molina, Arminius, Plaifere, Goad, and Wesley on Human Free-Will, Divine Omniscience, and Middle Knoweledge," Wesleyan Theological Journal, vol. 27 (1992): 93-103.

Bud, Livia. "Sant'Agostino e il rapporto tra libero arbitrio e grazia" Scientific Journal of Humanistic Studies 3, no. 4 (2011): 25.

Burns, J. Patout. The Development of Augustine's Doctrine of Operative Grace. Paris: Etudes Augustiniennes, 1980.

. "Grace" in Augustine Through the Ages: An Encyclopedia. Edited by Allan D. Fitzgerald. Grand Rapids, MI: Eerdmans, 1999.

. "Prevenient Grace" in Encyclopedia of Early Christianity. Edited by Everett Ferguson. New York: Garland Publishing, 1990.

Cairns, Earle E. Christianity Through the Centuries: A History of the Christian Church, 3rd ed. Grand Rapids, MI: Zondervan, 1996.

Calvin, John. The Bondage and Liberation of the Will: A Defense of the Orthodox Doctrine of Human Choice Against Pighius. Edited by A. N. S. Lane, and translated by G. I. Davies, Texts \& Studies in Reformation \& Post-Reformation Thought. Grand Rapids, MI: Baker, 1996.

. Institutes of the Christian Religion. Translated by Henry Beveridge. Peabody, MA: Hendrickson, 2008. 
Canale, Fernando. Basic Elements of Christian Theology: Scripture Replacing Tradition. Berrien Springs, MI: Fernando Canale, 2005.

Casiday, A. M. C. Tradition and Theology in St John Cassian. New York: Oxford University Press, 2007.

Cassian, John. "The Conferences of John Cassian," in Sulpitius Severus, Vincent of Lérins, John Cassian, Vol. 11. Edited by P. Schaff and H. Wace, and translated by E. C. S. Gibson. New York: Christian Literature Company, 1894.

. Corpus Scriptorum Ecclesiasticorum Latinorum, Iohannis Cassiani Opera, vol. 24. Vindabonae: Apvd C. Geroldi Filium Bibliopolam Academiae, 1886.

Chadwick, Henry. The Church in Ancient Society: From Galilee to Gregory the Great. New York: Oxford University Press, 2001.

Chadwick, Owen. John Cassian. New York: Cambridge University Press, 1968.

Chemnitz, Martin. Loci Theologici, Translated by J. A. O. Preus, vol. 1. St. Louis, MO: Concordia, 1989.

Clark, Mary T. Augustine. London: Geoffrey Chapman, 1994.

Clarke, F. Stuart. "Arminius's Understanding of Calvin," Evangelical Quarterly 54, (1982): 25-35.

. "Arminius's Use of Ramism in His Interpretation of Romans 7 and 9." in Interpreting the Bible: Historical and Theological Studies in Honour of David F. Wright. Edited by A. N. S. Lane. Leicester, England: Apollos, 1997.

. The Ground of Election: Jacobus Arminius's Doctrine of the Work and Person of Christ. Colorado Springs, CO: Paternoster, 2006.

Cochrane, Arthur C. ed. Reformed Confessions of the Sixteenth Century. Louisville, KY: Westminster John Knox, 2013.

Colish, Marcia L. "Peter Lombard," in The Medieval Theologians: An Introduction to Theology in the Medieval Period. ed. G. R. Evans. Malden, MA: Blackwell, 2001.

Cooper, J. P. ed., The New Cambridge Modern History: The Decline of Spain and the Thirty Years War 1609-48/59, 4 vols. Cambridge, UK: Cambridge University Press, 1970.

Cossee, Eric H. "Arminius and Rome," in van Leeuwen, Th. Marius, Keith D. Stanglin, and Marijke Tolsma, Arminius, Arminianism, and Europe: Jacobus Arminius (1559/60-1609). Leiden, the Netherlands: Brill, 2009. 
Craig, William Lane. What Does God Know? Reconciling Divine Foreknowledge and Human Freedom. Norcross, GA.: Ravi Zacharias International Ministries, 2002.

Creswell, Dennis R. St. Augustine's Dilemma: Grace and Eternal Law in the Major Works of Augustine of Hippo. New York: Peter Lang, 1997.

Cunningham, William. Historical Theology: A Review of the Principal Doctrinal Discussions in the Christian Church Since the Apostolic Age, 2 vols. Edinburgh: T \& T Clark, 1863.

Curtis, Geo L. Arminianism in History; or, The Revolt from Predestinationism. Cincinnati, OH: Cranston \& Curts, 1894.

de Clerq, Caroli. Corpus christianorum, Series Latina, Concilia Galliae, A. 511-A. 695, Vol. 148A. Tvrnholti: Typographi Brepols Editores Pontificii, 1963.

Dekker, Evert, Rijker dan Midas: Vrijheid, genade en predestinatie in de theologie van Jacobus Arminius 1559-1609. Zoetermeer, the Netherlands: Uitgeverij Boekencentrum B.V., 1993.

. "Was Arminius a Molinist?," Sixteenth-Century Journal 27, no. 2 (1996): $337-$ 352.

de Molina, Luis. Concordia del libre arbitrio con los dones de la gracia y con la presciencia, providencia, predestinación y reprovación divinas. trans. Juan Antonio Hevia Echevarría. Oviedo, España: Pentalfa, 2007.

den Boer, William. God's Twofold Love: The Theology of Jacob Arminius 1559-1609, trans. Albert Gootjes. Göttingen, Germany: Vandenhoeck \& Ruprecht, 2010.

Denck, Hans. "Divine Order" in Selected Writings of Hans Denck, Edited and Translated by Edward J. Furcha and Ford Lewis Battles. Pittsburgh, PA: The Pickwick Press, 1975.

Den Tex, Jan. Oldenbarnevelt:1606-1619. Translated by R. B. Powell, Vol. 2. London: Cambridge University Press, 1973.

Dickens, A. G. The Counter Reformation. Harcourt, Brace and World, Inc., 1969.

Donnelly, John Patrick, S.J. Calvinism and Scholasticism in Vermigli's Doctrine of Man and Grace. Leiden, the Netherlands: Brill, 1976.

Douglas, James D. “Arminius, Jacobus (1559-1609)" in Who's Who in Christian History. Edited by J. D. Douglas and Philip W. Comfort. Wheaton, IL: Tyndale House, 1992. 
Duke, Alastair. "The Netherlands," in The Early Reformation in Europe. Edited by Andrew Pettegree. New York: Cambridge University Press, 1992.

Dupont, Anthony. Gratia in Augustine's Sermones ad Populorum During the Pelagian Controversy. Leiden, the Netherlands: Brill, 2013.

Eaton, David Eugene. "Arminianism in the Theology of John Wesley." Ph.D. Diss., Drew University, 1988.

Edwards, Jonathan. A History of the Work of Redemption, in The Works of Jonathan Edwards, Vol. 1 New York: Leavitt \& Allen, 1856.

Ellingsen, Mark. Reclaiming Our Roots: Martin Luther to Martin Luther King. Harrisburg, PA: Trinity Press International, 1999.

Ellis, Mark A. ed. and trans., The Arminian Confession of 1621. Eugene, OR: Pickwick, 2005. . Simon Episcopius's Doctrine of Original Sin. New York: Peter Lang, 2006.

. "Simon Episcopius's Doctrine of Original Sin.” PhD diss., Dallas Theological Seminary, 2002.

Elorduy, Eleuterio. “San Augustín y Suárez: El doctor de la gracia,” Augustinus 16 (1971): 34.

Emery, Gilles O.P., "The Holy Spirit in Aquinas's Commentary on Romans," in Reading Romans with St. Thomas Aquinas, Edited by Matthew Levering and Michael Dauphinais. Washington, D.C.: The Catholic University of America Press, 2012.

Estep, William R. The Anabaptist Story: An Introduction to Sixteenth-Century Anabaptism, Third Edition. Grand Rapids, MI: Eerdmans, 1996.

Evans, Robert E. Pelagius: Inquiries and Reappraisals. New York: The Seabury Press, 1968.

Ferguson, John. Pelagius. Cambridge, England: W. Heffer and Sons, 1956.

Fesko, John V. "Arminius on Facientibus Quod In Se Est and Likely Medieval Sources," in Church and School in Early Modern Protestantism: Studies in Honor of Richard A. Muller on the Maturation of a Theological Tradition. Edited by Jordan J. Ballor, David S. Sytsma, and Jason Zuidema. Leiden, the Netherlands: Brill, 2013. 
. Beyond Calvin: Union with Christ and Justification in Early Modern Reformed Theology, 1517-1700, Reformed Historical Theology. Edited by Herman J.

Selderhuis, vol. 20. Göttingen, Germany: Vandenhoeck \& Ruprecht, 2012.

Forlines, F. Leroy. Classical Arminianism: A Theology of Salvation. Nashville, TN: Randall House, 2011.

Frame, John M. Systematic Theology: An Introduction to Christian Belief. Phillipsburg, NJ: P\&R, 2013.

Freeman, Thomas. "Dissenters from a Dissenting Church: The Challenge of the Freewillers, 1550-1558," in The Beginning of English Protestantism. Edited by Peter Marshall and Alec Ryrie. Cambridge, UK: Cambridge University, 2002.

Friedmann, Robert. The Theology of Anabaptism: An Interpretation. Scottdale, PA: Herald Press, 1973.

Geisler, Norman L. Systematic Theology in One Volume. Minneapolis, MN: Bethany, 2011.

George, Timothy. Theology of the Reformers. Nashville, TN: Broadman \& Holman, 1988.

Glare, P. G. W. Oxford Latin Dictionary. New York: Oxford University Press, 1982.

Godfrey, W. Robert. "Demythologizing Arminius: A Fresh Look at His Life." Paper presented at the 66th annual meeting of the Evangelical Theological Society, San Diego, CA, November 19-21, 2004.

González, Justo. A History of Christian Thought, Vol. 3, From the Protestant Reformation to the Twenty Century, Rev. ed. Nashville, TN: Abigdon Press, 1987.

. The History of Theological Education. Nashville, TN: Abingdon Press, 2015. eBook Collection (EBSCOhost), EBSCOhost (accessed March 15, 2017).

. The Story of Christianity, Vol. 2, The Reformation to the Present Day. San Francisco, CA: Haper \& Row, 1984.

Gotthard, V. Lechler. John Wiclif and His English Precursors. London: Kegan Paul, Trench, 1881.

Goudriann, Aza. ““Augustine Asleep' or 'Augustine Awake’? Jacobus Arminius Reception of Augustine," in Arminius, Arminianism, and Europe: Jacobus Arminius (1559/60-1609). Edited by Th. Marius van Leeuwen, Keith D. Stanglin, and Marijke Tolsma. Leiden, the Netherlands: Brill, 2009. 
Gratsch, Edward J. Aquinas' Summa: An Introduction and Interpretation. Staten Island, New York: Alba House, 1985.

Graybill, Gregory B. Evangelical Free Will: Philipp Melanchthon's Doctrinal Journey on the Origins of Faith. New York: Oxford University Press, 2010.

Grenz, Stanley J. Theology for the Community of God. Grand Rapids, MI: Eerdmans, 2000

Gunter, W. Stephen. Arminius and His Declaration of Sentiments: An Annotated Translation with Introduction and Theological Commentary. Waco, TX: Baylor, 2012.

Hales, John. Golden Remains of the Ever Memorable Mr. John Hales, of Eaton-College, with Additions from the Author's Own Copy, vol. 12; Fourth edition. London: E. Pawlet, 1711.

Hall, H. Ashley. Philip Melanchthon and the Cappadocians: A Reception of Greek Patristic Sources in the Sixteenth Century. Göttingen, Germany: Vandenhoeck \& Ruprecht, 2014.

Hanna, Martin, Darius Jankiewicz, and John Reeve, eds., Salvation: Contours of Adventist Soteriology. Berrien Springs, MI: Andrews University Press, forthcoming.

Hargrave, O. T. "The Freewillers in the English Reformation," Church History, vol. 37, no. 3 (1968):271-280.

Harmon, Thomas P. "The Sacramental Consummation of the Moral Life According to St. Thomas Aquinas." New Blackfriars 91/1034 (2010): 466.

Harnack, Adolph. History of Dogma, Vol. 5. Boston, MA: Little, Brown, and Company, 1899.

Hauben, Paul L. Three Spanish Heretics and the Reformation. Genève, Switzerland: Librairie Droz, 1967.

Heering, J. P. Hugo Grotius as Apologist for the Christian Religion: A Study of His Work 'De veritate religionis christianae,' 1640. Leiden, the Netherlands: Brill, 2004.

Hicks, John M. "The Righteousness of Saving Faith: Arminian Versus Remonstrant Grace," Evangelical Journal, vol. 9, no. 1 (Spring, 1991): 27-39.

. "The Theology of Grace in the Thought of Jacobus Arminius and Philip Van Limborch: A Study in the Development of Seventeenth-Century Dutch Arminianism." Ph.D diss., Westminster Theological Seminary, 1985. 
Hodge, Charles. Systematic Theology. Vol. 3. Grand Rapids, MI: Eerdmans, 1952.

Horton, Michael. For Calvinism. Grand Rapids, MI: Zondervan, 2011.

. The Christian Faith: A Systematic Theology for Pilgrims On the Way. Grand Rapids, MI: Zondervan, 2011.

Hubmaier, Balthasar. Balthasar Hubmaier: Theologian of Anabaptism. Edited by H. Wayne Pipkin and John H. Yoder. Scottdale, PA: Herald Press, 1989.

. "On Free Will," in Spiritual and Anabaptist Writers: Documents Illustrative of the Radical Reformation, xxv vol. Edited by George Huntston Williams, Library of Christian Classics. Philadelphia, PA: Westminster, 1962.

Huggins, Ronald V. "Romans 7 and the Ordo Salutis from Arminius to Ironside (15911928): With Special Emphasis on the American Revivalist Tradition in its TransAtlantic Connection.” Ph.D. diss., Wycliffe College and Toronto University, 1996.

Hulshoff Pol, Elfriede. The First Century of Leiden University Library. Leiden, the Netherlands: Brill, 1975.

Hwang, Alexander Y. Intrepid Lover of Perfect Grace: The Life and Thought of Prosper of Aquitaine. Washington D.C.: The Catholic University of America Press, 2009.

Israel, Jonathan I. Dutch Primacy in World Trade, 1585-1740. New York: Oxford, 2002.

Jansen, Geert H. The Dutch Revolt and Catholic Exile in Reformation Europe. Cambridge, UK: Cambridge University Press, 2014.

Kärkkäinen, Veli-Matti. "Ordo Salutis," in Global Dictionary of Theology: A Resource of the Worldwide Church. Edited by William A. Dyrness and Veli-Matti Kärkkäinen. Downers Grove, IL and Nottingham, UK: InterVarsity Academic, 2008 .

Keathley, Kenneth. Salvation and Sovereignty: A Molinist Approach. Nashville, TN: B\&H Academic, 2010.

Kecskeméti, Gábor. "The Reception of Ramist Rhetoric in Hungary and Transylvania: Possibilities and Achievements" in Ramus, Pedagogy and the Liberal Arts: Ramism in Britain and the Wider World. Edited by Steven J. Reid and Emma Annette Wilson. Burlington, VT: Ashgate, 2011.

Kelly, J. N. D. Early Christian Doctrines. New York: Harper One, 1978. 
Kerr, Fergus. "Thomas Aquinas" in The Medieval Theologians: An Introduction to Theology in Medieval Period. Edited by G. R. Evans. Malden, Massachusetts: Blackwell Publisher, 2001.

Kieng Ting, Moi. Augustine's and Wesley's Concepts of Prevenient Grace: A Comparative Study. Saarbrücken, Germany: Lambert, 2010.

Kirchner, Hubert. "Trent, Council of" in The Encyclopedia of Christianity, Edited by Erwin Fahlbusch, Jan Milič Lochman, John Mbiti, Jaroslav Pelikan, and Lukas Vischer. Grand Rapids, MI: Eerdmans, 2008.

Kooi, Christine. "The Netherlands," in Reformation and Early Modern Europe: A Guide to Research. Edited by David M. Whitford. Kirksville, MO: Truman State University Press, 2008.

Korthaase, Werner. "Phillip Melanchthon, Praeceptor Germaniae, and His Influence on Theories of Education in Bohemia and Moravia" in Luther and Melanchthon in the Educational Thought in Central and Eastern Europe. Edited by Reinhard Golz and Wolfgang Mayrhofer. Münster, Germany: Lit, 1998.

Krahn, Cornelius. Dutch Anabaptism: Origin, Spread, Life and Thought 1450-1600. The Hague, the Netherlands: Martinus Nijhoff, 1968.

Kuiper, Herman. Calvin on Common Grace. Goes, the Netherlands: Oosterbaan \& Le Cointre, 1928.

Lechler, Gotthard V. John Wiclif and His English Precursors. London: Kegan, Paul, Trench, 1881.

Leinsle, Ulrich G. Introduction to Scholastic Theology. Translated by Michael J. Miller. Washington D.C.: Catholic University of America Press, 2010.

Lindeboom, L. Het Bijbelsch humanisme in Nederland. Leiden, the Netherlands: 1913.

Lombard, Peter. The Sentences, vol. 2, On Creation, trans. Guilio Silano. Toronto: PIMS, 2008.

Luijten, Eric. Sacramental Forgiveness as a Gift of God: Thomas Aquinas on the Sacrament of Penance. Utrecht, the Netherlands: Peeters Leuven, 2003.

Luther, Martin. The Bondage of the Will. Translated by Henry Cole. Lexington, KY: Legacy, 2011.

. Commentary on the Epistle to the Romans. Translated by J. Theodore Mueller. Grand Rapids, MI: Kregel, 1976. 
MacGregor, Kirk R. A Molinist-Anabaptist Systematic Theology. Lanham, MD: University Press of America, 2007.

. The Life and Theology of the Founder of Middle Knowledge. Grand Rapids, MI: Zondervan, 2015.

Mallison, Jeffrey. Faith, Reason, and Revelation in Theodore Beza, 1519-1605, Oxford Theological Monographs. Oxford, UK: Oxford University Press, 2003.

Manschreck, Clyde L. Melanchthon: The Quiet Reformer. Eugene, OR: Wipf and Stock Publishers, 2008.

Marnef, Guido. "The Changing face of Calvinism in Antwerp, 1550-1585," in Calvinism in Europe, 1540-1620, ed. Andrew Pettegree, Alastair Duke, and Gilliam Lewis. New York: Cambridge University Press, 1994.

Mathisen, Ralph W. "Caesarius of Arles, Prevenient Grace, and the Second Council of Orange," in Grace for Grace: The Debates after Augustine and Pelagius. Edited by Alexander Y. Hwang, Brian J. Matz, and Augustine Casiday. Washington, D.C.: The Catholic University of America Press, 2014.

McCall, Thomas H. "Was Arminius and (Unvitting) Determinist? Another Look at Arminius'ss Modal Logic," Journal of Reformed Theology, 8 (2014): 301-309.

McCoy, Charles S. and J. Wayne Baker. Fountainhead of Federalism: Heinrich Bullinger and the Covenantal Tradition. Louisville, KT: Westminster/John Knox, 1991.

McCulloh, Gerald. Man's Faith and Freedom: The Theological Influence of Jacobus Arminius. Eugene, OR: Wipf and Stock Publishers, 2006.

McFadden, W. "The Life and Works of Antonio del Corro, 1527-1591." PhD diss., Queen's University Belfast, 1953.

Meeuwsen, James. "Original Arminianism and Methodistic Arminianism Compared," The Reformed Review, vol. 14, no. 1 (September, 1960): 21-36.

Meijering, E. P. Melanchthon and Patristic Thought: The Doctrines of Christ and Grace, the Trinity, and the Creation. Leiden, the Netherlands: Brill, 1983.

Melanchthon, Phillip. The Chief Theological Topics: Loci Praecipui Theologici 1559. Translated by J. A. O. Preus, 2nd ed. St. Louis, MO: Concordia, 2011.

. Melanchthon on Christian Doctrine: Loci communes 1543. Translated by J. A. Preus. St. Louis, MO: Concordia, 1992. 
. Melanchthon on Christian Doctrine: Loci communes 1555. Translated by Clyde L. Manschreck. Grand Rapids, MI: Baker Book House, 1965.

. Philippi Melanthonis Opera Quae Supersunt Omnia, ed. Henricus Ernestus Bindseil, Corpus Reformatorum 21. Brunsvigae: apud C. A. Schwetzke Et Filium, 1854.

Muller, Richard. After Calvin: Studies in the Development of a Theological Tradition, Oxford Studies in Historical Theology. New York: Oxford University Press, 2003.

. "Arminius and Arminianism" in The Dictionary of Historical Theology. Edited by Trevor A. Hart. Cumbria, United Kingdom and Grand Rapids, MI: Pasternoster and Eerdmans, 2000.

. "Arminius and the Reformed Tradition," Westminster Theological Journal 70, no. 1 (2008): 19-48.

. "Arminius and the Scholastic Tradition," Calvin Theological Journal 24, no. 2 (1989): 263-277.

. Christ and the Decrees: Christology and Predestination in Reformed Theology from Calvin to Perkins. Durham, NC: The Labyrinth, 1986.

. "The Federal Motif in Seventeenth Century Arminian Theology" Nederlandsch Archief Voor Kerkgeschiedenis 62/1 (1982): 102-122.

. God, Creation, and Providence in the Thought of Jacob Arminius: Sources and Directons of Scholastic Protestantism in the Era of Early Orthodoxy. Grand Rapids, MI: Baker, 1991.

. "Grace, Election, and Contingent Choice: Arminius's Gambit and the Reformed Response" in The Grace of God, the Bondage of Will: Historical Perspectives on Calvinism, 2 vols. Edited by Thomas R. Schreiner and Bruce A. Ware. Grand Rapids, MI: Baker, 1995.

. "John Calvin and Later Calvinism: The Identity of the Reformed Tradition," in The Cambridge Companion to Reformed Theology. Edited by David Bagchi and David C. Steinmetz. Cambridge, UK: Cambridge University Press, 2004.

. Post-Reformation Reformed Dogmatics: Prolegomena to Theology: The Rise and Development of Reformed Orthodoxy, ca. 1520 to ca. 1725, 4 vols., Second Edition. Grand Rapids, MI: Baker, 2003.

. "The Priority of the Intellect in the Soteriology of Jabob Arminius," Westminster Theological Journal 55.1 (1993): 55-72. 
. "Problem of Protestant Scholastism-A Review and Definition," in Reformation and Scholasticism: An Ecumenical Enterprise. Edited by Willem J. Van Asselt and Eef Dekker. Grand Rapids, MI: Baker, 2001.

. "Reflections on Persistent Whiggism and Its Antidotes in the Study of Sixteenthand Seventeenth-Century Intellectual History," in Seeing Things Their Way: Intellectual History and the Return of Religion. Edited by Alister Chapman, John Coffey, and Brad S. Gregory. Notre Dame, IN: University of Notre Dame Press, 2009.

. "Reformation, Orthodoxy, 'Christian Aristotelianism," Nederlands Archief voor Kerkgeschiedenis 81 (2001): 306-325.

Mullet, Michael A. The Catholic Reformation. New York: Routledge, 1999.

Murdock, James. Mosheim's Institutes of Ecclesiastical History, Ancient and Modern. Revised by James Seaton Reid. London: William Tegg, 1878.

Nichols, Aidan. Discovering Aquinas: An Introduction to His Life, Work, and Influence. Grand Rapids, MI: Eerdmans, 2002.

Nicole, Roger. "The Case for Definite Atonement," Bulletin of the Evangelical Theological Society 10/4 (1967):199.

Oberman, Heiko A. Dawn of the Reformation. Grand Rapids, MI: Eerdmans, 1992. . Luther: Man Between God and the Devil. New Haven, CT: Yale, 1989.

. The Reformation: Roots and Ramifications. Translated by Andrew Colin Gow. New York: T \& T Clark, 1994.

Olson, Oliver K. Matthias Flacius and the Survival of Luther's Reform. Wiesbaden, Germany: Harrasswitz, 2002.

Olson, Roger E. "Are Arminian Theology and Middle Knowledge Compatible?" in http://www.patheos.com/blogs/rogereolson/2013/09/are-arminian-theology-andmiddle-knowledge-compatible/, accessed January 28, 2016.

. Arminianism FAQ: Everything You Always Wanted to Know. Roger E. Olson, 2014.

. "Arminianism is God-Centered Theology" in Grace for All: The Arminian Dynamics of Salvation. Edited by Clark H. Pinnock and John D. Wagner. Eugene, OR: Wipf and Stock, 2015. 
. Arminian Theology: Myths and Realities. Downers Grove, IL: InterVarsity Press, 2006.

. The Story of Christian Theology: Twenty Centuries of Tradition and Reformation. Downers Grove, IL: InterVarsity Press, 1999.

O’Malley, John W. Trent: What Happened at the Council. Cambridge, MA: Harvard University Press, 2013.

Ozment, Stephen. The Age of Reform, 1250-1550: An Intellectual and Religious History of Late Medieval and Reformation Europe. New Haven, CT: Yale University Press, 1981.

Parker, Geoffrey. The Grand Strategy of Philip II. New Haven, CT: Yale University Press, 1998.

. Imprudent King: A New Life of Philip II. New Haven, CT: Yale University Press, 2014.

. Philip II. Boston, MA: Little, Brown and Company, 1978.

Pelagius, Defense of the Freedom of the Will. Translated and Reconstructed by Daniel R. Jennings. Patristic in English. Accessed March 21, 2017. http://www.seanmulti media.com/Pie_Pelagius_Defense_Of_The_Freedom_of_The_Will.html.

. On Nature, Translated and Reconstructed by Daniel R. Jennings. Patristic in English. Accessed March 21, 2017. http://www.seanmultimedia.com/Pie_Pelagius _On_Nature.html.

. Pelagius's Commentary on St. Paul's Epistle to the Romans. Translated by Theodore de Bruyn. New York: Oxford University Press, 1993.

Pelikan, Jaroslav. The Christian Tradition: A History of the Development of Doctrine, The Emergence of the Catholic Tradition (100-600), vol. 1. Chicago, IL: The University of Chicago Press, 1971.

. The Growth of Medieval Theology (600-1300), in The Christian Tradition: A History of the Development of Doctrine, vol. 3. Chicago, IL: The University of Chicago, 1978.

Peterson, Robert A. and Michael D. Williams, Why I Am Not an Arminian. Downers Grove, IL: IVP, 2004.

Pettegree, Andrew. "The Calvinist Church in Holland, 1572-1590," in Calvinism in Europe, 1540-1620. Edited by Andrew Pettegree, Alastair Duke, and Gilliam Lewis. New York: Cambridge University Press, 1994. 
, Europe in the Sixteenth Century. Malden, MA: Blackwell, 2002.

Picirilli, Robert E. "Foreknowledge, Freedom, and the Future," Journal of Evangelical Theological Society 43/2 (June 2000): 263-271.

. Grace, Faith, Free Will-Contrasting Views of Salvation: Calvinism and Arminianism. Nashville, TN: Randall House, 2002.

Pinson, J. Matthew. "Will the Real Arminius Please Stand up? A Study of the Theology of Jacobus Arminius in Light of His Interpreters.” Integrity 2 (2003): 121-139.

Platt, Frederic Platt. "Arminianism” in Encyclopedia of Religion and Ethics. Edited by J. Hasting. New York: Charles Scribner's Sons, 1908.

Platt, John. Reformed Thought and Scholasticism: The Arguments for the Existence of God in Dutch Theology, 1575-1650. Leiden, the Netherlands: Brill, 1982.

Rabbie, Edwin. "General Introduction” in Hugo Grotius, Ordinum Hollandiae ac Westfrisiae pietas (1613); Critical Edition with English Translations and commentary. Edited by Edwin Rabbie, in Studies in the History of Christian Thought, vol. LXVI, Edited by Heiko A. Oberman. Leiden, the Netherlands: Brill, 1995.

Ramsey, Boniface. "John Cassian and Augustine," in Grace for Grace: The Debates after Augustine and Pelagius. ed. Alexander Y. Hwang, Brian J. Matz, and Augustine Casiday. Washington, D.C.: The Catholic University of America Press, 2014.

Rees, B. R. Pelagius: A Reluctant Heretic. Wolfeboro, NH: Boydell, 1988.

Richard, James. Philip Melanchthon: The Protestant Preceptor of Germany 1497-1560. New York: G. P. Putnam's Sons, 1898.

Rist, John M. Augustine: Ancient Thought Baptized. New York: Cambridge University Press, 1994.

Rogness, Michael. Melanchthon: Reformer without Honor. Minneapolis, MN: Augsburg Publishing House, 1969.

Schöffer, I. "De crisis van de jonge Republiek 1609-1625," in Alegeme Geschiedenis der Nederlanden. Edited by J. A. van Houtte, J. F. Niermeyer and J. Presser, VI (Utrech, 1953), cited by Edwin Rabbie, "General Introduccion," in Hugo Grotius, Ordinum Hollandiae Ac Westfrisiae Pietas (1613); Critical Edition with English Translation and Commentary in Studies in the History of Christian Thought, vol 66. Edited by Heiko A. Oberman. Leiden, the Netherlands: Brill, 1995. 
Schroeder, H. J. Canons and Decrees of the Council of Trent: Original Text with Translation. St. Louis, MO: B. Herder Book, 1941.

Sébastien, Louis. The Life of Augustine: Childhood to Episcopal Consecration (354396). Translated by Frederick Van Fleteren. New York: Peter Lang, 2010.

Seeberg, Reinhold. Text-Book of the History of Doctrines, Vol. 1. Grand Rapids, MI: Baker Book House, 1952.

Selderhuis, Herman ed., Handbook of the Dutch Church. Göttingen: Vandenhoeck \& Ruprecht, 2015.

Shelton, W. Brian. Prevenient Grace: God's Provision for Fallen Humanity. Wilmore, KY: Francis Asbury Press, 2014.

Shultz Jr., Gary L. A Multi-Intentioned View of the Extent of the Atonement. Eugene, OR: Wipf \& Stock, 2013.

Slaatte, Howard. The Arminian Arm of Theology: The Theologies of John Fletcher, First Methodist Theologian, and his Precursor, James Arminius. Washington, D.C.: University Press of America, 1978.

Smith, Warren T. Augustine: His Life and Thought. Atlanta, GA: John Knox Press, 1980.

Snyder, Arnold C. Anabaptist History and Theology: An Introduction. Kitchener, Ontario: Pandora Press, 1995.

. Following in the Footsteps of Christ: The Anabaptist Tradition. Maryknoll, NY: Orbis Books, 2004.

. The Life and Thought of Michael Sattler. Scottdale, PA: Herald Press, 1984.

Spaans, Joke. "Reform in the Low Countries," in A Companion to the Reformation World. Edited by R. Po-Chia Hsia. Malden, MA: Blackwell, 2004.

Sproul, R. C. Willing to Believe: The Controversy over Free Will. Grand Rapids: Baker Books, 1997.

Stanciu, Diana. "Re-Interpreting Augustine: Ralph Cudworth and Jacobus Arminius on Grace and Free Will," Zeitschrift für antikes Christentum 11, no. 1 (2007): 96114.

Stanglin Keith D. "Arminianism," in Global Dictionary of Theology. Edited by William A. Dyrness and Veli-Matti Kärkkäinen. Downers Grove, IL: InterVarsity Academic, 2008. 
. "Arminius Avant La Lettre': Peter Baro, Jacob Arminius, and the Bond of Predestinarian Polemic.” Westminster Theological Journal 67 (2005): 58.

. "Arminius and Arminianism: An Overview of Current Research," in Arminius, Arminianism, and Europe: Jacobus Arminius (1559/60-1609). Edited by Th. Marius van Leeuwen, Keith D. Stanglin, and Marijke Tolsma. Leiden, the Netherlands: Brill, 2009.

. Arminius on the Assurance of Salvation: The Context, Roots, and Shape of the Leiden Debate, 1603-1609. Leiden, the Netherlands: Brill, 2007.

. "Arminius Reconsidered: Thoughts on Arminius and Contemporary Theological Discourse for the Church Today," in Reconsidering Arminius: Beyond the Reformed and Wesleyan Divide. Edited by Keith D. Stanglin, Mark G. Bilby, and Mark H. Mann. Nashville, TN: Kingswood Books, 2014.

. The Missing Public Disputations of Jacobus Arminius, ed. Wim Janse. Leiden, the Netherlands: Brill, 2010.

Stanglin Keith D. and Richard A. Muller, "Bibliographia Arminiana," in Arminius, Arminianism, and Europe: Jacobus Arminius (1559/60 - 1609). Edited by Th. Marius van Leeuwen, Keith D. Stanglin, and Marijke Tolsma. Leiden, the Netherlands: Brill, 2009.

Stanglin Keith D. and Thomas H. McCall. Jacob Arminius: Theologian of Grace. New York: Oxford University Press, 2012.

Stayer, James M. Anabaptists and the Sword. Lawrence, KA: Coronado Press, 1972

Stephens, W. P. The Holy Spirit in the Theology of Martin Bucer. New York: Cambridge University Press, 1970.

. The Theology of Huldrych Zwingli. New York: Oxford University Press, 1986.

Studebaker, Steven M. "The Mode of Divine Knowledge in Reformation Arminianism and Open Theism," Journal of Evangelical Theological Society 47/3 (September 2004): 469-480.

Stupperich, Robert. Melanchthon. Translated by Rober H. Fisher. Philadelphia, PA: Westminster, 1965.

Sumruld, William A. Augustine and the Arians: The Bishop of Hippo's Encounters with Ulfilan Arianism. Cranbury, NJ: Associated University Presses, 1994. 
Tanner, Norman. "Trent, Council of" in The Oxford Companion to Christian Thought. Edited by Adrian Hastings, Alistair Mason, and Hugh Pyper. New York: Oxford University Press, 2000.

TeSelle, Eugene. Augustine. Nashville, TN: Abingdon Press, 2006.

Torrell, Jean Pierre. Saint Thomas Aquinas: The Person and His Work. Translated by Robert Royal. Revised edition. Washington, D.C: The Catholic University of America Press, 2005.

. Thomas Aquinas: Aquinas's Summa Background, Structure, and Reception. Washington, D.C: The Catholic University of America Press, 2005.

Tugnell, Simon. Albert and Aquinas: Selected Writings. Mahwah, NJ: Paulist Press, 1988.

Tyacke, Nicholas. Anti-Calvinists: The Rise of English Arminianism c. 1590-1640. Oxford: Clarendon, 1987.

Ullmann, Carl. Reformers Before the Reformation, Principally in Germany and The Netherlands, vol. 2. Translated by Robert Menzies. Edinburgh, Scotland: T \& T Clark, 1850.

Valero, Juan B. Las bases antropológicas de Pelagio en su tratado de las Expositiones. Mardrid, España: Publicaciones de la Universidad Pontifica Comillas, 1980.

van Asselt, Willem J. Introduction to Reformed Scholasticism, Reformed HistoricalTheological Studies. Edited by Joel R. Beeke, and Jay T. Collier, and translated by Albert Gootjes. Grand Rapids, MI: Reformation Heritage Books, 2011.

van Asselt, Willen J. and Paul H.A.M. Ables, "The Seventeenth Century," in Handbook of the Dutch Church, Edited by Herman Selderhuis. Göttingen: Vandenhoeck \& Ruprecht, 2015.

van den Belt, Henk. The Authority of Scripture in Reformed Theology: Truth and Trust. Leiden, the Netherlands: Brill, 2008.

van den Brink, Gijsbert. Almighty God: A Study of the Doctrine of Divine Omnipotence, Studies in Philosophical Theology. Kampen, The Netherlands: Pharos, 1993.

van Deursen, A. T. "The Dutch Republic, 1588-1780" in History of the Low Countries. Edited by J. C. Blom and E. Lamberts, and translated by James C. Kennedy. New York: Berghahn, 2006. 
van Leeuwen, Th. Marius, Keith D. Stanglin, and Marijke Tolsma, Arminius, Arminianism, and Europe: Jacobus Arminius (1559/60-1609). Leiden, the Netherlands: Brill, 2009.

van Oosterhout, Moniek. "Hugo Grotius in Praise of Jacobus Arminius: Arminian Readers of An Epicedium in the Dutch Republic and England" in Literary Cultures and Public Opinion in the Low Countries, 1450-1650. Edited by Jan Bloemendal, Arjan van Dixhoorn, and Elsa Strietman. Leiden, the Netherlands: Brill, 2011.

van Veen, Mirjam G. K. "Calvin and His Opponents," in The Calvin Handbook. Edited by Herman J. Selderhuis, trans. Henry J. Baron, Judith J. Guder, Randi H. Lundell, and Gerrit W. Sheeres. Grand Rapids, MI: Eerdmans, 2009. . “. . . la cause des puissans ...' Sebastian Castellio's picture of John Calvin” in Reformed Majorities in Early Modern Europe. Edited by Herman J. Selderhuis and J. Marius J. Lange van Ravenswaay. Göttingen, Germany: Vandenhoeck \& Ruprecht, 2015.

van Veen, Mirjam G. K. and Jesse Spohnholz, "Calvinists vs. Libertines: A New Look at Religious Exile and the Origins of 'Dutch' Tolerance" in Calvinism and the Making of European Mind. Edited by Gijsbert van den Brink and Harro M. Höpfl. Leiden, the Netherlands: Brill, 2014.

Wallace, Dewey D Jr., Puritans and Predestination: Grace in English Protestant Theology, 1525-1695. Eugene, OR: Wipf \& Stock, 1982.

Walls, Jerry L. Does God Love Everyone? The Heart of What is Wrong with Christianity. Eugene, OR: Cascade, 2016.

Warfield, B. B. "Introduction to Augustine's Anti-Pelagian Writings," in Nicene and Post-Nicene Fathers (NPNF). Edited by Philip Schaff, translated by P. Holmes and Robert E. Wallis, and revised by Benjamin B. Warfield., vol. 5: Augustine: Anti-Pelagian Writings. New York: Christian Literature Company, 1887, reprint, 2012.

Weaver, Rebecca Harder. Divine Grace and Human Agency: A Study of the SemiPelagian Controversy. Macon, GA: Mercer University Press, 1996.

Weisheipl, James. Friar Thomas D'Aquino: His Life, Thought, and Works. Garden City, NY: Doubleday, 1974.

Wengert, Timothy J. Human Freedom, Christian Righteousness: Philip Melanchthon's Exegetical Dispute with Erasmus of Rotterdam. New York: Oxford University Press, 1998. 
. "Philip Melanchthon and the Origins of the "Three Causes' $(1533$ - 1535): An Examination of the Roots of the Controversy over the Freedom of Will" in Philip Melanchthon: Theologian in Classroom, Confession, and Controversy. Edited by Irene Dingel, Robert Kolb, Nicole Kuropka, and Timothy J. Wengert. Göttingen, Germany: Vandenhoeck and Ruprecht, 2012.

. Philip Melanchthon: Theologian in Classroom, Confession, and Controversy. Göttingen, Germany: Vandenhoeck \& Ruprecht, 2012.

Wesley, John. The Question, What is an Arminian? Answered, quoted in Benjamin Myers, Milton's Theology of Freedon. Berlin, Germany: De Gruyter, 2006.

White, Peter. Predestination, Policy, and Polemic: Conflict and Consensus in the English Church from the Reformation to the Civil War. New York: Cambridge University Press, 1992.

William, George Huntston. The Radical Reformation, Third Edition. Kirksville, MO: Truman State University, 1992.

Wim, Balke. "Calvin and the Anabaptists," in The Calvin Handbook. Edited by Herman J. Selderhuis, and trans. Henry J. Baron, Judith J. Guder, Randi H. Lundell, and Gerrit W. Sheeres. Grand Rapids, MI: Eerdmans, 2009.

Witt, William G. "Creation, Redemption and Grace in the Theology of Jacob Arminius." Ph.D. diss., Notre Dame University, 1993.

Woodbridge, John D. and Frank A. James III. Church History From Pre-Reformation to the Present Day: The Rise and Growth of the Church in Its Cultural, Intellectual, and Political Context. vol. II. Grand Rapids, MI: Zondervan, 2013.

Wright, Shawn D. Our Sovereign Refuge: The Pastoral Theology of Theodore Beza. Studies in Christian History and Thought. Cumbria, UK: Pasternoster, 2004.

Wynkoop, Mildred Bangs. Foundations of Wesleyan-Arminian Theology. Kansas City, KS: Beacon Hill Press, 1967. 